Luís Roberto de Souza

\title{
Condicionantes sociais na delimitação de espaços endêmicos de hanseníase
}

Tese apresentada à Faculdade de Medicina da Universidade de São Paulo para obtenção do título de Doutor em Ciências

Orientador: Prof. Dr. Nelson da Cruz Gouveia

(Versão Corrigida. Resolução CoPGr 6018/11, de 1 de novembro de 2011. A versão original está disponível na Biblioteca da FMUSP)

São Paulo 
Dados Internacionais de Catalogação na Publicação (CIP)

Preparada pela Biblioteca da

Faculdade de Medicina da Universidade de São Paulo

Creprodução autorizada pelo autor

Souza, Luís Roberto de

Condicionantes sociais na delimitação de espaços endêmicos de hanseníase / Luís Roberto de Souza. -- São Paulo, 2012.

Tese(doutorado)--Faculdade de Medicina da Universidade de São Paulo.

Programa de Medicina Preventiva.

Orientador: Nelson da Cruz Gouveia.

Descritores: 1.Áreas de pobreza 2.Atenção primária à saúde 3.Distribuição espacial da população 4.Doença endêmica 5.Doenças negligenciadas 6.Epidemiologia 7.Estudos ecológicos 8.Exposição a agentes biológicos 9.Fatores socioeconômicos 10.Grupos populacionais 11.Hanseníase

12.Imunidade coletiva 12.Migração interna 14.Saúde ambiental 15.Saúde na fronteira 16.Tolerância imunológica 17.Topografia médica 
Em homenagem ao primeiro centenário da Faculdade de Medicina da Universidade de São Paulo

$(1912-2012)$

Para minha esposa, com carinho.

Fique para aqueles com os quais convivi durante meu ofício, pacientes e colegas de trabalho, que contribuíram de algum modo para que eu pudesse pensar o problema tratado aqui, meu singelo tributo na forma desta tese, pois tenho aprendido com vocês a lição de que a fartura nasce da partilha. 

Sou grato pela orientação do Prof. Nelson Gouveia, que acreditou no meu projeto e com rigor científico desprovido de rigidez conduziu-me generosamente até aqui. Meus agradecimentos aos demais docentes e aos funcionários do Departamento de Medicina Preventiva, pelo acesso aos recursos pedagógicos que tornaram possível levar adiante e concluir este trabalho. Obrigado aos docentes que me ensinaram os primeiros passos com a "soroepidemiologia da rubéola" e instigaram-me a prosseguir, em especial os professores Julio Litvoc e Raymundo Azevedo. Minha gratidão à ajuda que me prestou o Sr Roosevelt, da Agência do IBGE de São Paulo, ao dirimir minhas dúvidas em muitas vezes. Sou grato aos técnicos do Hospital "Lauro Souza Lima" de Bauru e do Instituto de Saúde de São Paulo, que propiciaram minha formação na área de hansenologia e diálogos motivadores, dirigindo críticas fundamentais para que eu avançasse. Meu agradecimento à Miriam Souza e ao Rogério Ruscitto pelo auxílio na confecção dos mapas e nas análises estatísticas e aos funcionários das bibliotecas da USP, sempre prontos e zelosos e a todos os colegas da Universidade que tornaram minha empreitada investigativa agradável e fraterna. 
"O território é o lugar do exercício da vida: é chão mais a identidade e identidade é o sentimento de pertencer àquilo que nos pertence. O território em si não é uma categoria de análise, pois ele não é apenas o conjunto dos sistemas naturais e dos sistemas de coisas superpostas, é o território usado que é uma categoria de análise. Por isto, toda a idéia que decorre do território, como a de nação, tem com ele uma relação tornada profunda, porque um faz o outro; o território ajuda a fabricar a nação para que a nação depois o afeiçoe."

Milton Santos (1926 - 2001)

"A grande lição que fica é a de que a ciência começa sempre com a descoberta, baseada em observações detalhadas e cuidadosas; enquanto a interpretação dos fatos observados, para ser válida, depende de conhecimentos comparativos de áreas diversas e de tempos diferentes, assim como do uso de eventuais instrumentos registradores ou amplificadores. Do cuidado nas observações e da multiplicação de trabalhos analíticos pode-se chegar a teorias sedutoras. E das teorias pioneiras e corretamente elaboradas é possível atingir inesperados conhecimentos".

Aziz Nacib Ab’Sáber (1924 - 2012)

"Peço-te aquilo, Tempo e te ofereço elogios, Tempo, nas rimas do meu estilo."

(“Oração ao Tempo", autoria desconhecida)

Agora que aquela pequena idéia "ganhou sangue e criou nervos" me encontro como um estudante, que ao desejar estar ao lado da dúvida acaba concordando que as respostas já sempre dormitam bem perto, mas ao arrancá-las descobre que "o essencial, em todas as coisas, é indemonstrável". Mas, e a verdade? Ah, aquela coisa nunca derradeira, mas antes, liberdade? 


\section{Normalização adotada}

Esta tese está de acordo com as seguintes normas, em vigor no momento desta publicação:

Referências: adaptado de International Committee of Medical Journals Editors (Vancouver)

Universidade de São Paulo. Faculdade de Medicina. Serviço de Biblioteca e Documentação. Guia de apresentação de dissertações, teses e monografias. Elaborado por Anneliese Carneiro da Cunha, Maria Julia de A. L. Freddi, Maria F. Crestana, Marinalva de Souza Aragão, Suely Campos Cardoso, Valéria Vilhena. 2a ed. São Paulo: Serviço de Biblioteca e Documentação; 2005.

Abreviaturas dos títulos dos periódicos de acordo com List of Journals Indexed in Index Medicus. 

Listas

Resumo

Summary

1 INTRODUÇÃO

1.1 A Hanseníase Doença 9

1.2 A Hanseníase Endemia 33

1.3 O Espaço em Epidemiologia e na Geografia 51

1.4 Apontamentos sobre o Método Ecológico 71

1.5 Hipóteses e justificativa $\quad 76$

2 OBJETIVOS

3 MÉTODOS $\quad 87$

3.1 Variável dependente 90

3.2 Indicadores sociodemográficos 93

3.3 Variáveis independentes $\quad 95$

3.4 Plano de análise dos dados 103

4 RESULTADOS 107

4.1 Apontamentos sobre o território em estudo 109

4.2 Descrição epidemiológica 118

4.3 Descrição sociodemográfica 125

4.4 Análise estatística 135

5 DISCUSSÃO 141

5.1 Hipóteses sobre o processo endêmico da hanseníase $\quad 170$

5.2 Contextualização dos resultados 198

5.3 Sobre o processo investigativo 218

6 CONCLUSÕES 229

7 ANEXO 235

8 REFERÊNCIAS $\quad 245$ 



\section{LISTA DE ABREVIATURAS}

Dr. doutor

et al. e outros

hab. habitantes

prob. probabilidade

prof. professor

M. leprae Mycobacterium leprae

\section{LISTA DE SÍMBOLOS}

$\begin{array}{ll}- & \text { negativo } \\ { }^{\circ} \mathrm{C} & \text { grau Celsius } \\ \% & \text { porcentagem } \\ > & \text { maior que } \\ < & \text { menor que } \\ = & \text { igual a } \\ \mathrm{km} & \text { quilômetro } \\ \mathrm{km}{ }^{2} & \text { quilômetro quadrado } \\ \mathrm{mm} & \text { milímetro } \\ \mathrm{n} & \text { frequência absoluta } \\ \mathrm{p} & \text { valor } \mathrm{p} \text { estatístico }\end{array}$




$\begin{array}{ll}P & \text { probabilidade } \\ R^{2} & \text { coeficiente de determinação } \\ R \$ & \text { reais } \\ t & \text { probabilidade } t \text { de Student }\end{array}$

\section{LISTA DE SIGLAS}

$\begin{array}{ll}\text { ADN } & \text { Ácido desoxirribonucléico } \\ \text { BCG } & \text { Bacilo de Calmette-Guérin } \\ \text { BR } & \text { Rodovia Federal } \\ \text { CID10 } & \text { Codificação Internacional de Doenças - Décima Revisão } \\ \text { CNES } & \text { Cadastro Nacional de Estabelecimentos de Saúde } \\ \text { Datasus } & \text { Departamento de Informática do Sistema Único de Saúde } \\ \text { ELISA } & \text { Imuno-absorção por ligação enzimática } \\ \text { ESF } & \text { Estratégia de Atenção "Saúde da Família" } \\ \text { Ferronorte } & \text { Ferrovia Norte Brasil } \\ \text { IBGE } & \text { Instituto Brasileiro de Geografia e Estatística } \\ \text { IDH } & \text { Índice de Desenvolvimento Humano } \\ \text { IDHM } & \text { Índice de Desenvolvimento Humano Municipal } \\ \text { MS } & \text { Mato Grosso do Sul } \\ \text { MT } & \text { Mato Grosso } \\ \text { OMS } & \text { Organização Mundial da Saúde }\end{array}$


ONU Organização das Nações Unidas

PEA População economicamente ativa

PCR Reação em Cadeia da Polimerase

PGL glicolipídio fenólico

PIB Produto Interno Bruto

PNAD Pesquisa Nacional por Amostra de Domicílios

POA Pessoal Ocupado com a Agricultura

PQT Poliquimioterapia

RIPSA Rede Interagencial de Informação para a Saúde

SIA Sistema de Informação Ambulatorial

SIAB Sistema de Informação da Atenção Básica

Sinan Sistema de Informação Nacional sobre Agravos de Notificação

Sinan-DOS Sistema de Informação Nacional sobre Agravos de Notificação na plataforma de programação computacional do tipo Disk Operating System

SUS Sistema Único de Saúde

TDMA Taxa de detecção média anual de casos de hanseníase

UF Unidade Federada

USP Universidade de São Paulo

WHO World Health Organization 


\section{LISTAS DE FIGURAS, TABELAS E MAPAS}

\section{LISTA DE FIGURAS}

Figura 1.1 - Taxa de prevalência de hanseníase calculada com dados notificados à OMS. Janeiro, 2009

Figura 1.2 - Taxa de detecção de casos diagnosticados recentemente de hanseníase calculada com dados notificados à OMS. Janeiro, 2009 38

Figura 4.1 - Região Centro-Oeste, Brasil 110

Figura 5.1 - Modelo hipotético sobre a difusão da hanseníase, com a participação de portadores transitórios, indução de hiporresponsividade imunológica e o impacto das migrações 188

Figura 5.2 - Esquema hipotético de reprodução, no nível coletivo, de casos secundários de hanseníase a partir de contatos repetidos com portadores transitórios do $M$. leprae 192

Figura 5.3 - Ciclos de transmissão da hanseníase 196 


\section{LISTA DE TABELAS}

Tabela 1.1 - Taxa de detecção média anual de casos de hanseníase (TDMA), Brasil, Unidades da Federação - 2001-2005

Tabela 4.1 - Caracterização socioeconômica geral, Mato Grosso e Mato Grosso do Sul

Tabela 4.2 - Taxa de detecção média anual de casos de hanseníase por 10.000 habitantes, bruta e por faixa etária e sexo, Mato Grosso e Mato Grosso do Sul - 2000-2006 122

Tabela 4.3 - Taxa de detecção média anual de casos de hanseníase por 10.000 habitantes, segundo a faixa etária e a classe operacional da forma clínica, Mato Grosso e Mato Grosso do Sul - $2000-2006$ 123

Tabela 4.4 - Taxa de detecção média anual de casos de hanseníase por 10.000 habitantes, segundo o sexo e a classe operacional da forma clínica, Mato Grosso e Mato Grosso do Sul - $2000-2006$ 
Tabela 4.5 - Razão de taxas de detecção entre Mato Grosso e Mato Grosso do Sul, segundo a classe operacional da forma clínica, sexo e faixa etária - $2000-2006$ 124

Tabela 4.6 - Casos de hanseníase segundo a avaliação de incapacidades físicas no momento do diagnóstico, Mato Grosso e Mato Grosso do Sul $-2000-2006$

Tabela 4.7 - População segundo a faixa etária e o sexo, no Mato Grosso e Mato Grosso do Sul - 2003 127

Tabela 4.8 - População residente em 1991 e 2000, por situação do domicílio, taxa de crescimento populacional, área total e densidade demográfica, Mato Grosso e Mato Grosso do Sul 128

Tabela 4.9 - Produto interno bruto per capita, taxa de desemprego e rendimento nominal médio mensal familiar, Mato Grosso e Mato Grosso do Sul - 2000 131

Tabela 4.10 - Pessoas sem instrução ou com menos de 4 anos de estudo, Mato Grosso e Mato Grosso do Sul - 2000 132 
Tabela 4.11 - Pessoas em domicílios particulares permanentes com seis ou mais moradores, em domicílios com mais de três pessoas por dormitório e em domicílios sem banheiro, Mato Grosso e Mato Grosso do Sul - 2000 132

Tabela 4.12 - Pessoas não naturais da Unidade da Federação (UF) e pessoas não naturais imigrantes nos últimos 10 anos, Mato Grosso e Mato Grosso do Sul - 2000 133

Tabela 4.13 - Cobertura populacional média da estratégia de Atenção Saúde da Família e média anual de consultas médicas do SUS em clínicas básicas por habitante, Mato Grosso e Mato Grosso do Sul - $2000-2006$ 133

Tabela 4.14 - População da área em estudo, segundo quartis de distribuição de municípios, ordenada por indicadores sociodemográficos e composição por Unidade Federada .... 134

Tabela 4.15 - Regressão linear simples com a variável dependente Taxa de detecção média anual de hanseníase 138

Tabela 4.16 - Modelo ajustado de estimação dos parâmetros de associação com a variável dependente Taxa de detecção média anual de hanseníase 139 


\section{LISTA DE MAPAS}

Mapa 1.1 - Casos de hanseníase detectados entre 1997 e 2006, segundo o município de residência, Brasil 46

Mapa 1.2 - Taxa de detecção média anual de casos de hanseníase (casos/10.000 habitantes), segundo o município de residência, Brasil - 2001-2005

Mapa 4.1 - Taxa de detecção média anual de hanseníase (casos/10.000 hab.), segundo o município de residência, Mato Grosso e Mato Grosso do Sul - 2000-2006

Mapa 4.2 - Taxa média anual de crescimento geométrico populacional (\% a.a.), municípios do Mato Grosso e Mato Grosso do Sul - 1991/2000 130

Mapa 4.3 - Proporção da população moradora em domicílios com 6 ou mais pessoas, municípios do Mato Grosso e Mato Grosso do Sul - 2000 
Mapa 4.4 - Proporção da população não natural da Unidade da Federação - UF, municípios do Mato Grosso e Mato Grosso do Sul -2000 140

Mapa 4.5 - Cobertura populacional média da estratégia de Atenção Saúde da Família, municípios do Mato Grosso e Mato Grosso do Sul $-2000-2006$ 140 

Souza L R. Condicionantes sociais na delimitação de espaços endêmicos de hanseníase. São Paulo, 2012. Faculdade de Medicina, Universidade de São Paulo. Departamento de Medicina Preventiva. Tese (doutorado). Área de concentração: Epidemiologia. Orientador: Nelson da Cruz Gouveia. 301 p.

INTRODUÇÃO: A hanseníase é uma doença infecciosa crônica granulomatosa, cujo agente etiológico é uma bactéria de vida intracelular obrigatória, o Mycobacterium leprae, que tem no homem seu principal reservatório. A doença possui distribuição universal, predominando atualmente, em latitudes tropicais e tem sido enquadrada entre as enfermidades negligenciadas, atingindo desproporcionalmente populações pobres e marginalizadas. O bacilo é altamente contagioso, de baixa patogenicidade e acomete primordialmente pele e nervos, com grande potencial incapacitante. A doença grassou no Velho Mundo durante a Idade Média e praticamente desapareceu da Europa ainda no início do século XX, antes que qualquer recurso terapêutico eficaz estivesse disponível. Introduzida com os primeiros colonizadores europeus, a hanseníase é doença endêmica no Brasil e um problema de saúde pública. A hanseníase é hiperendêmica em muitos municípios, notadamente nos estados das regiões Norte e Centro-Oeste, que abrangem biomas de cerrado, pântano e floresta amazônica, em vastas áreas de baixa densidade demográfica; estas áreas vêm sofrendo enorme pressão antrópica relacionada ao incremento de atividades agropecuárias e extrativistas, gerando preocupações em relação ao impacto ambiental sobre a saúde humana, decorrente de transformações na dinâmica territorial. OBJETIVO: O propósito desta pesquisa foi conhecer o efeito ecológico de fatores sociodemográficos na delimitação de espaços endêmicos de hanseníase e gerar hipóteses sobre a relação entre a constituição do território e a exposição ambiental ao agente biológico da doença. MATERIAL E MÉTODOS: Supondo que a variação dos fatores de risco para contrair hanseníase pudesse ser maior entre grupos populacionais do que entre indivíduos, foi empreendido um estudo epidemiológico de delineamento ecológico do tipo grupo múltiplo, envolvendo 203 municípios dos estados do Mato Grosso e Mato Grosso do Sul, que estão localizados na região Centro-Oeste do Brasil. Foram constituídas variáveis sociodemográficas de exposição e a variável de efeito foi representada pela taxa de detecção média anual de hanseníase entre os anos de 2000 e 2006. Foram aproveitados dados secundários provenientes do Instituto Brasileiro de Geografia e Estatística e do Ministério da Saúde. Para compor um modelo multivariado, 14 variáveis foram analisadas por regressão linear simples e selecionadas sete variáveis com probabilidade de $p<0,2$ para o coeficiente de inclinação da reta de regressão. As variáveis independentes selecionadas foram passo a passo testadas, simultaneamente e analisada a associação da variável dependente, visando o ajuste de um modelo singular da variabilidade da taxa de detecção de hanseníase. RESULTADOS: As variáveis que restaram no modelo após o processo de ajuste foram: "Proporção da população moradora em domicílios com seis ou mais pessoas"; "Proporção da população não natural do estado"; e, "Cobertura populacional da estratégia de Atenção Saúde da 
Família". Estas variáveis juntas explicam $24,1 \%$ da variação nas taxas de detecção de hanseníase. CONCLUSÕES: Fatores sociodemográficos representam um importante domínio na epidemiologia da doença. A associação positiva do desfecho com a cobertura da estratégia de Atenção Saúde da Família indica que deve haver melhora no acesso ao diagnóstico mediante a implantação de modelos de Atenção Primária à Saúde baseados em racionalidades preventivas. Doentes poderiam ter sua contagiosidade interrompida mais precocemente, uma vez melhorada a capacidade diagnóstica dos serviços de saúde. Como recomendação para melhorar o acesso ao diagnóstico nas áreas endêmicas, a adoção da estratégia de Atenção Saúde da Família deve ser encorajada. Aglomeração domiciliar como variável ecológica foi interpretada como sendo um indicador socioeconômico indireto, mais do que propriamente relacionada às condições de contato. A qualidade da moradia, talvez seja mais importante para controle da endemia, tanto quanto possa vir acompanhada de melhorias gerais no padrão de vida. Reservatórios do $M$. leprae constituídos por indivíduos que eliminam bacilos cronicamente são os que perpetuam a endemia, embora possam, em tese, serem suplementados por fontes secundárias representadas por portadores transitórios. Fatores ligados à formação da fronteira agrícola e à urbanização brasileira podem ter fomentado a endemia de hanseníase, ao predisporem a renovação de susceptíveis pelas migrações, que modificam a composição populacional quanto à experiência de contato com o bacilo. Migrações poderiam romper os focos de hanseníase que estivessem saturados de indivíduos resistentes ao redistribuir espacialmente a população susceptível, levar infectantes para áreas indenes ou instalar as premissas biológicas e territoriais para tornar o contágio recorrente na população, mesmo que o contingente demográfico proveniente de imigrações não seja predominantemente mais vulnerável à doença. Tecnicização rural e constrições na esfera do trabalho têm movimentado populações que procuram refúgio nas periferias das cidades, caracterizadas por escassa infraestrutura urbana e rápido crescimento demográfico, supostamente continentes de grupos humanos dotados de diferentes perfis de resistência ao $M$. leprae. O circuito inferior da economia, uma resposta social à escassez de meios de vida e um traço da territorialização brasileira, tem oferecido os predicados espaciais para a persistência da endemia de hanseníase nos bolsões de pobreza urbana, ao gerar uma multiplicidade de contatos em proximidade e alimentar suas relações sociais de uma massa de recém-chegados do campo e da cidade, sua principal e mais abundante variável. Se a geografia estuda as condições de vida sobre a terra, estes resultados sugerem que a topografia médica, para além da descrição dos aspectos demográficos e socioeconômicos dos lugares de surgimento de doenças, pode contribuir em muito ao conhecimento em saúde, ao considerar analisar tais fatores enquanto potenciais condicionantes de endemias. 
Descritores: 1. Áreas de Pobreza 2. Atenção Primária à Saúde 3. Distribuição Espacial da População 4. Doença Endêmica

5. Doenças Negligenciadas 6. Epidemiologia 7. Estudos Ecológicos

8. Exposição a Agentes Biológicos 9. Fatores Socioeconômicos

10. Grupos Populacionais 11. Hanseníase 12. Imunidade Coletiva

13. Migração Interna 14. Saúde Ambiental 15. Saúde na Fronteira

16. Tolerância Imunológica 17 . Topografia Médica. 

Souza L R. Social conditions in the delimitation of areas endemic for leprosy [thesis]. São Paulo: "Faculdade de Medicina, Universidade de São Paulo"; 2012. $301 \mathrm{p}$.

BACKGROUND: Leprosy is a chronic granulomatous infectious disease whose causative agent is an obligate intracellular bacterium of life, Mycobacterium leprae, which has its main reservoir in man. The disease has a worldwide distribution, currently prevailing in tropical latitudes and has been framed between neglected diseases, disproportionately affecting poor and marginalized populations. The bacillus is highly contagious, and low pathogenic primarily affects the skin and nerves, with great potential crippling. The disease raged in the Old World during the Middle Ages and still practically disappeared from Europe in the early twentieth century, before any effective therapeutic resource was available. Introduced with the first European settlers, leprosy is endemic in Brazil and a public health problem. Leprosy is hyperendemic in many cities, especially in the states of North and Midwest, covering biomes savannah, swamp and rainforest, in vast areas of low population density; these areas have suffered huge human pressure related to increased activity agricultural and extractive, generating concerns about the environmental impact on human health, due to dynamic changes in territorial. OBJECTIVE: The purpose of this research was to understand the ecological effect of sociodemographic factors in the delimitation of leprosyendemic areas and generating concerns about the relationship between the constitution of the territory and environmental exposure to the biological agent of the disease. MATERIAL AND METHODS: Assuming that the variation of the risk factors for contracting leprosy could be higher among population groups than between individuals, an epidemiological study was undertaken to design ecological type group multiple, involving 203 municipalities in the states of Mato Grosso and Mato Grosso do Sul, which are located in the Midwest region of Brazil. Sociodemographic variables were recorded for exposure and effect was variable represented by annual average detection rate of leprosy between 2000 and 2006. We utilized secondary data from the Brazilian Institute of Geography and Statistics and the Ministry of Health to compose a multivariate model, 14 variables were analyzed by linear regression and seven variables selected with probability $p<0.2$ for the slope coefficient of regression line. The independent variables were tested step by step, and simultaneously analyzed the association of the dependent variable in order to fit a model of the variability of the detection rate of leprosy. The variables that remained in the model after adjustment process were: "Proportion of population living in households with six or more people," "Proportion of population unnatural state," and "Coverage of Population Health Care Strategy Family ". These variables together explain $24.1 \%$ of the variation in detection rates of leprosy. CONCLUSIONS: Sociodemographic factors represent an important area in the epidemiology of the disease. The positive association with the outcome of the strategic coverage of Family Health Care indicates that there must be improved access to diagnosis by implementing models of primary care-based preventive rationales. Patients could have their contagiousness interrupted 
earlier, once improved the diagnostic capacity of health services. As a recommendation to improve access to diagnosis in endemic areas, the adoption of the strategy of the Family Health Care should be encouraged. Household crowding as ecological variable was interpreted as an indirect socioeconomic indicator, rather than strictly related to contact conditions. The quality of housing, perhaps most important for disease control, as far as can be accompanied by general improvements in living standards. Reservoirs of $M$. leprae consist of individuals who are chronically eliminate bacilli that perpetuate endemic, although, in theory, be supplemented by secondary sources represented by transient carriers. Factors related to the formation of the agricultural frontier and the Brazilian urbanization may have fostered endemic leprosy, predispose to the renewal of the likely migration, which modify the composition of the population as to the experience of contact with the bacillus. Migration could break outbreaks of leprosy that were saturated with individuals resistant to spatially redistribute the population likely lead to infective areas unaffected or install the territorial and biological assumptions to make the recurring infection in the population, even though the population from immigration quota is not predominantly more vulnerable to disease. Technicisation rural and constrictions in the sphere of labor are busy people seeking refuge on the outskirts of cities, characterized by poor urban infrastructure and rapid population growth, supposedly continents groups of humans with different resistance profiles to $M$. leprae. The lower circuit of the economy, a social response to the scarcity of livelihood and a dash of Brazilian territorialization, has offered the spatial predicates for the persistence of endemic leprosy in pockets of urban poverty, to generate a plurality of contacts in proximity and feed their social relationships from a mass of newcomers from the countryside and the city, its main and most abundant variable. If geography studies the conditions of life on earth, these results suggest that medical topography, beyond the description of the demographic and socioeconomic aspects of the places outbreaks of diseases, can contribute greatly to health knowledge, to consider examining such factors as potential determinants of diseases.

Keywords: 1. Border Health 2. Ecological Studies 3. Endemic Diseases 4. Environmental Health 5. Epidemiology 6. Exposure to Biological Agents 7. Herd Immunity 8. Immune Tolerance 9. Internal Migration 10. Leprosy 11. Medical Topography 12. Neglected Diseases 13. Population Groups 14. Poverty Areas 15. Primary Health Care 16. Residence Characteristics 17. Socioeconomic Factors 
1. Introdução 



\section{Introdução}

A hanseníase continua a ser um sério problema de saúde pública em nosso país, muito ligada à precariedade das condições de vida. A população em risco de contrair a doença é grande e incapacidades físicas ameaçam uma parcela significativa dos enfermos, fazendo com que o sofrimento humano resultante transcenda os números que representam hoje o tamanho da endemia.

O conhecimento sobre a hanseníase é muito antigo. Evidências materiais da ocorrência da doença foram encontradas no Egito, datadas de 200 anos antes de Cristo; presume-se que focos primitivos de hanseníase surgiram no Egito e na Índia, de onde a infecção se propagou para o restante do mundo (Brownie, 1985).

Durante a Idade Média a hanseníase manteve alta prevalência na Europa e Oriente Médio. Em algumas regiões da Europa ocidental, as autoridades da Igreja Católica instituíram regras para isolar os doentes da população sadia. Desta época, surgiram as primeiras ordens religiosas dedicadas a prestar cuidados aos doentes de hanseníase. A magnitude do problema da hanseníase pode ser estimada pela existência, no século XIII, de 19 mil abrigos para doentes no continente europeu; durante o século 
XVII, com o declínio da endemia, houve uma desativação gradual destes abrigos (Eidt, 2004).

Ao final do século XIX, a hanseníase já havia praticamente desaparecido da Europa; mesmo na Noruega, onde ainda podia ser considerada endêmica, sua incidência já se achava em declínio (Lie, 1933). É suposto que este declínio da hanseníase, quando ainda não havia nenhum tratamento antimicrobiano eficaz, teve como causa principal a melhoria das condições socioeconômicas experimentadas pelo povo europeu (Irgens e Erkedal, 1973).

Paralelamente à tendência de desaparecimento da hanseníase da Europa, focos endêmicos na Ásia e na África eram mantidos e a doença espalhava-se pelo Novo Continente, a partir das conquistas Ibéricas. A história da hanseníase no Brasil começa com a colonização lusitana (Monteiro, 1987).

Em Portugal, a doença era endêmica no século XIV. Não havia registro da doença entre indígenas do Brasil e os primeiros casos de hanseníase apareceram no ano de 1600, na cidade do Rio de Janeiro; outros casos da doença foram em seguida identificados na Bahia e no Pará. A instalação do regime de produção colonial, baseado em mão-de-obra escrava, degredada da África para movimentar de matéria prima o comércio europeu do açúcar, fez com que cidades portuárias como Recife, Salvador e Rio de Janeiro, que recebiam uma grande massa de pessoas, estivessem em pouco tempo transformadas em focos de hanseníase. Durante o período 
de colonização da América Latina, esta parte do Continente tornou-se uma das novas áreas endêmicas mundiais (Belda, 1981).

Segundo Maurano (1939), desde o Brasil Colonial, muitos aldeamentos, tanto litorâneos como no interior, foram assolados pela hanseníase. Já no século XVIII, o número de doentes preocupava as autoridades das principais vilas e cidades, datando desta época, o surgimento das "Sociedades Protetoras dos Lázaros" e de pensões domiciliares para isolamento dos doentes (Marzliak et al., 2008).

No século XVIII, com o ciclo econômico de exploração do ouro, a hanseníase passa a acompanhar as levas humanas que adentravam a parte mais central do território, conforme era dito à época, como uma verdadeira "sombra". No entanto, as primeiras iniciativas do Governo Colonial frente à situação da endemia só foram tomadas no início do século XIX, com a regulamentação do combate à doença promovida por D. João V; mas, estas foram limitadas, na prática, à construção de abrigos e uma precária assistência aos doentes (Eidt, 2004).

A segregação dos doentes de hanseníase em "lazaretos" era uma providência para afastá-los do convívio social, não compreendendo a função de proteger os indivíduos sadios do contágio, ideia que iria se afirmar somente a partir do século XIX. O isolamento, enquanto uma tecnologia social de exclusão (Nemes, 1989), reunia frequentemente, em um mesmo espaço, todo o tipo de gente considerada "impura" pela sociedade. 
No início do século XX, Emílio Ribas, Oswaldo Cruz e Alfredo da Matta denunciaram o descaso do combate à endemia e o problema da hanseníase passa a ser reconhecido pelo Estado. Doença de difícil diagnóstico e incurável até aquele momento, a hanseníase soava como uma sentença de segregação (Benchimol e Romero Sá, 2003); talvez, por estes motivos, somente em 1902 que a "lepra ulcerada" seria incorporada ao grupo de enfermidades que deveriam ser comunicadas às autoridades sanitárias, fazendo vários estados oficializarem o isolamento compulsório (Santos et al., 2008) como uma das práticas "saneadoras" derivadas da concepção bacteriológica sobre a transmissão da hanseníase (Nemes, 1989).

O isolamento dos doentes em hospitais sanatórios foi uma iniciativa que não se revelou capaz de controlar a endemia, mas contribuiu para aumentar o medo e o estigma associados à doença. Segundo o relato de Quagliato (1951), apresentar-se às autoridades sanitárias como comunicante de paciente de hanseníase era considerado vexatório.

Oliveira et al. (2003) levantaram representações sociais confusas em relação à hanseníase, sugerindo que o neologismo aplicado há mais de 40 anos no Brasil para designar a doença ainda carece de iniciativas de comunicação social para divulgá-lo; o que poderia contribuir para tornar o termo hanseníase imediatamente apreensível pela população geral, com significados mais condizentes com o conhecimento científico atual e não perpetuadores de estigmas. 
Monteiro (1987) considera que as estruturas governamentais criadas com a finalidade de controlar a hanseníase acabavam compondo instâncias de poder totalitário dentro do próprio Estado, com arbítrio sobre a liberdade do cidadão acometido pela doença e sua tutela por parte do serviço médico oficial.

O instrumento coercitivo, de base legal, que iria dar cabo de reproduzir, na esfera da vida social, a ideologia da "sociedade sã", afastada do perigo de contágio da hanseníase, foi a "polícia sanitária"; a qual o Estado, respaldado pelo estatuto de verdade científica da jovem Epidemiologia, iria patrocinar (Nemes, 1989).

Em 1920, com a criação do Departamento Nacional de Saúde Pública, que teve à frente o sanitarista Carlos Chagas (Santos et al., 2008), as iniciativas governamentais estiveram voltadas à construção de abrigos para doentes em todos os estados endêmicos de hanseníase; a execução do censo populacional de acometidos pela enfermidade; e, a provisão de recursos para o tratamento com o óleo de chaulmoogra.

Em 1935, é instalado o Departamento de Profilaxia da Lepra e um novo plano de ação para o controle da hanseníase é elaborado, a assistência foi estendida aos familiares dos doentes por meio das instituições filantrópicas. Em 1941, é instaurado o Serviço Nacional de Lepra e no ano seguinte foi iniciado um censo de doentes, que apontou a Região Norte como sendo a de maior prevalência do país. À época, já se fazia menção sobre a elevada endemicidade da hanseníase na Amazônia poder 
estar relacionada à migração que acompanhou o ciclo econômico da borracha (Silveira et al., 2009), altamente empregador de trabalho para o extrativismo nos seringais. Quase meio século mais tarde, Britto (1989) mostra os números da doença para a Região Norte, considerando-os elevados em relação ao restante do país, tendo encontrado uma prevalência de 50,1 e incidência de 42,7 casos de hanseníase por 10 mil habitantes.

Embora o controle bacteriológico da hanseníase por tratamento químico tenha sido possibilitado pela descoberta da Diamino-difenil-sulfona em 1941 (Savassi, 2010), nos Estados Unidos, por Guy Henry Faget (1891 1947); o tratamento ambulatorial para a doença iria se firmar no Brasil somente na década de 1960, com o fim da política de isolamento (Marzliak et al., 2008).

No estado de São Paulo, data do início da década de 1970 uma transformação dos antigos dispensários em "Centros de Saúde", em acordo com a nova racionalidade que viria orientar as ações em hanseníase (Nemes, 1989).

Doenças transmissíveis como a hanseníase continuam a impedir o pleno desenvolvimento social e econômico do país, fazendo do conhecimento sobre os fatores que dificultam sua eliminação uma prioridade em pesquisa científica no campo da saúde (Sabroza et al., 2000).

Para Meyers (1995), a produção científica em hanseníase ao final do século XX, período de florescimento de novos conhecimentos em imunologia, genética e biologia molecular, apresentou muitos resultados que 
ajudaram a elucidar os caminhos fisiopatogênicos da doença; mas, grande expectativa se faz, ainda, em torno dos desenvolvimentos biomédicos propiciados por tais avanços para o controle da endemia. Atualmente, o controle está baseado na interrupção da transmissão pelo tratamento quimioterápico de doentes, que tem oferecido cura bacteriológica eficaz.

Os conhecimentos desenvolvidos pelos hansenologistas da "Era PréSulfônica" continuam a lastrear o diagnóstico até os dias de hoje. Segundo Fleury (2005), mesmo a terapêutica mais eficiente e os procedimentos mais modernos em prevenção e correção de incapacidades, tiveram sua introdução entre as décadas de 1940 e 1970. A perspectiva de desenvolvimento de ferramentas eficientes para detecção de casos subclínicos ou de vacinas para prevenir a infecção parece ainda muito distante. Diante deste cenário, é preciso aperfeiçoar os mecanismos de controle da doença, onde conhecer melhor a epidemiologia da hanseníase, as variações regionais de apresentação da endemia e seus possíveis condicionantes sociais, se constitui em uma das metas deste esforço.

\subsection{A Hanseníase Doença}

A hanseníase é uma doença infecciosa crônica granulomatosa, de distribuição universal, que afeta primordialmente o tecido cutâneo-mucoso e nervos periféricos. Das contribuições inaugurais de Rabello (1936) sobre as 
formas polares da hanseníase, chegou-se à classificação adotada internacionalmente no Congresso de Madri (1953), recomendando nomear as apresentações clínicas da doença em forma virchowiana; dimorfa ou borderline; tuberculóide; e, indeterminada. As duas primeiras são definidas, operacionalmente, como sendo multibacilares e as duas últimas, paucibacilares (Organização Mundial da Saúde - OMS, 1989).

\section{Agente Etiológico}

O agente etiológico da hanseníase é uma bactéria de nome científico Mycobacterium leprae, de característica tintorial álcool-ácido-resistente e Gram-positiva, parasitismo intracelular obrigatório, morfologia em bastonete, reprodução por divisão binária e geração lenta, em torno de 11 até 13 dias (Gentilini et al., 1986). Não se dispõe de meios de cultura artificiais para o $M$. leprae, o que tem impossibilitado sua reprodução in vitro (Scollard et al., 2006).

O M. leprae, primeiro patógeno humano reconhecido ao microscópio ótico, foi descoberto pelo médico norueguês Gerhard Henrick Armauer Hansen (1841 - 1912), em 1873 (Rees, 1985), adquirindo o microrganismo, posteriormente, também o reconhecimento como "bacilo de Hansen". Esta micobactéria possui alta infecciosidade e baixa patogenicidade, capaz de 
produzir alta proporção de infectados e portadores sãos (Lombardi e Ferreira, 1990). É espécie única entre as micobactérias que afetam nervos periféricos, possui baixa letalidade e elevado potencial incapacitante (Leiker, 1974).

\section{Fontes de Infecção e Reservatórios}

A fonte de infecção e reservatório principal é o homem, mas a doença não é exclusiva de seres humanos (Deps, 2001). O significado de outras fontes de infecção e dos reservatórios naturais não está completamente elucidado, embora exista conhecimento sobre algumas de suas potencialidades na transmissão da hanseníase.

Demonstrou-se a presença de bacilos na água, alimentos e no leite de mães doentes de hanseníase, mas não há evidência direta de transmissão da doença por ingestão (Noordeen, 1994).

A ocorrência de fontes não humanas de $M$. leprae tem sido amplamente investigada. Foi cunhado o termo "contato" para indicar situações de proximidade física suficiente para que um indivíduo seja exposto a uma fonte de contaminação, onde pode ser encontrado um agente físico, químico ou biológico (Baldy, 1989). Chama atenção o fato de não se conseguir obter história de contato para a maioria dos doentes de hanseníase (Joseph et al., 1985). 
Alguns autores têm relatado que em amostras do solo, da vegetação e da água foram encontrados antígenos específicos de micobactérias não cultiváveis, cuja inoculação em animais reproduziu doença semelhante à hanseníase de humanos (Kazda, 1981; Kazda et al., 1986; Kazda e Irgens, 1990).

$\mathrm{Na}$ Indonésia, em lugarejos endêmicos foi demonstrada a contaminação da água com $M$. leprae e uma maior prevalência de hanseníase entre indivíduos que usavam água contaminada para beber (Matsuoka et al., 1999).

Algumas espécies de artrópodes podem se constituir em fonte de infecção ao servirem como vetores mecânicos de bacilos. Bacilos álcoolácido resistentes foram encontrados em carrapatos amostrados do ambiente de permanência ou diretamente recolhidos do corpo de doentes de hanseníase não tratados (Souza Araújo, 1941). Moscas e mosquitos podem dispersar o bacilo no ambiente ao adquirir o $M$. leprae da pele ulcerada ou do muco nasal depositado nas superfícies e carrear os bacilos a locais distantes (Geater, 1975).

O tatu (Dasypus novemcinctus) é utilizado como modelo animal para experimentos in vivo em hanseníase (Storrs, 1971; Opromolla et al., 1980; Acha e Szyfres, 1989; Naafs, 2000), antes mesmo de ter sido comprovada infecção natural nestes animais. Em algumas partes da América do Norte, este mamífero primitivo é considerado uma possível fonte de infecção e reservatório natural de $M$. leprae, mas não se conhece completamente o 
significado da ecologia de interação entre tatus e seres humanos na distribuição da infecção (Truman, 2005; Paige et al., 2002). Cardona-Castro et al. (2009), utilizando métodos para detecção de ácido desoxirribonucleico (ADN) específico, encontraram tatus contaminados com M. leprae em uma região endêmica para hanseníase na Colômbia, onde o contato e consumo da carne deste animal são comuns. Truman et al. (2011) acrescentaram evidências para considerar a hanseníase como sendo uma doença enzoótica em algumas regiões. Estudando amostras de ADN de M. leprae coletados de tatus infectados naturalmente, capturados no sul dos Estados Unidos, os autores encontraram identidade genotípica com amostras de ADN de M. leprae, obtidas de pacientes moradores em locais onde havia possibilidade de exposição àqueles animais.

Doença naturalmente adquirida, semelhante à hanseníase de humanos, tem sido encontrada em outras espécies de primatas (Walsh et al., 1981).

\section{Transmissão e Incubação}

O modo de transmissão da hanseníase considerado mais relevante para a propagação da infecção é por contato direto e a rota respiratória é a mais provável (Levy, 1983). Há relato de transmissão experimental de hanseníase em linhagem de camundongos imunodeficientes pela exposição 
tópica ao M. leprae na mucosa nasal e por injeção subcutânea (Chehl e Job, 1985).

O período de incubação é de dois a cinco anos em média e a latência da infecção tende a variar de acordo com a carga bacilar de exposição e a susceptibilidade individual (Pfaltzgraff e Bryceson, 1985). Comumente a incubação é mais longa na forma virchowiana do que na forma tuberculóide (Shepard, 1982).

Acredita-se que o período de transmissão dure pelo menos desde o início dos sintomas e seja interrompido com a introdução de tratamento químico específico; mas, sobre um período de transmissibilidade antecedendo o aparecimento de sintomas é assunto ainda pouco esclarecido. Estima-se que cada doente multibacilar, quando não tratado, produza cerca de cinco novos doentes ao ano; e, quando tratado inadequadamente, possa facilitar a disseminação de bacilos resistentes às medicações atuais (Margarido-Marchese et al., 1996).

$\mathrm{Na}$ transmissão pela rota respiratória é suposto que $\circ M$. leprae invada o corpo pela mucosa respiratória e ganhe a corrente sanguínea através dos pulmões, tal como pode ocorrer na tuberculose. A principal via de eliminação e penetração do bacilo é o trato respiratório superior, particularmente a mucosa nasal. A transmissão pode ocorrer de forma direta, pela inalação de gotículas de secreção oral e nasal suspensas no ar, na forma de aerossóis, eliminadas por doentes bacilíferos ao tossir, espirrar, falar ou, ainda, indiretamente pela inalação de partículas ressecadas 
contendo bacilos viáveis depositadas no ambiente; que podem ser veiculadas pelo fluxo de ar e por outros agentes mecânicos inertes ou biológicos. Também são relatadas outras vias de eliminação, tais como nódulos ulcerados, leite materno e secreções sebáceas (Huang, 1980).

Em vista da capacidade do $M$. leprae sobreviver fora do corpo humano, há possibilidade de a doença ser transmitida por contato indireto; mas o contato direto é tido como mais efetivo (Noordeen, 1994). Um doente multibacilar não tratado pode eliminar milhões de bacilos por dia nas secreções oronasais ou por ulcerações da pele (McDougall, 1973; Davey, 1974).

Em um estudo onde se obteve $M$. leprae de pacientes não tratados, demonstrou-se que os bacilos, após secagem à sombra, permaneceram viáveis por cinco meses; em solo úmido, por 46 dias; em solução salina à temperatura ambiente, por 60 dias; expostos durante três horas ao sol, diariamente, sobreviveram por sete dias; refrigerados a $4^{\circ} \mathrm{C}$, por 60 dias; e, congelados à $-70^{\circ} \mathrm{C}$, por 28 dias (Desikan e Sreevatsa, 1995).

Além da porta de entrada respiratória, admite-se que o bacilo de Hansen possa ser introduzido no corpo humano através da pele lesada (Leiker, 1977), mas não pelo epitélio íntegro, uma vez que o bacilo é inerte, desprovido de mobilidade e não produz toxinas (Job, 1981). Casos de adoecimento por hanseníase algum tempo após picada com agulha contaminada (Langen, 1933), vacinação com BCG intradérmico e punctura de pele durante tatuagem têm sido mencionados (Deps, 2001); sendo 
plausível que em certas atividades profissionais a porta de entrada cutânea esteja favorecida.

Tem sido aventada a transmissão do $M$. leprae por inoculação intracutânea, quando da picada de insetos contaminados. Foi demonstrada experimentalmente, com camundongos, a viabilidade de bacilos transferidos por mosquitos, após estes terem picado voluntários virchowianos (Banerjee et al., 1991).

Entre os fatores relacionados ao contágio, a dose da exposição é um importante definidor do risco (Moet et al., 2004). Estudos envolvendo diversas condições de exposição têm ajudado a explicar parte das diferenças no risco de adoecimento entre situações de convívio social, comportamentos, ocupações e práticas culturais.

Noordeen e Neelan (1978) encontraram uma razão de taxas de ataque de hanseníase para contatos de casos virchowianos até 2,5 vezes mais que entre não contatos.

Noordeen (1994) relata uma escala crescente de riscos relativos de contrair hanseníase quando comparados: não contatos $(1,0)$, contatos de casos não multibacilares $(3,7)$, contatos de casos multibacilares e não multibacilares $(4,5)$ e contatos de casos multibacilares $(9,5)$.

Para ajudar a compreender a propagação de uma doença transmissível tem sido usado o termo "contato fechado", que diz respeito a um modelo epidemiológico de transmissão onde há estabilidade dos contatos (Edmunds et al., 2006). 
No contato fechado ou íntimo é assumido que os contatos promotores da disseminação de um patógeno tendem a se repetir com certa estabilidade dentro de um mesmo grupo de parceiros, podendo assumir relações de dependência em forma de rede. Contatos fechados são comuns nos ambientes domiciliares, escolares e laborais; eles são mais facilmente identificáveis que contatos abertos, como os contatos eventuais na comunidade. Contatos abertos seriam aqueles de caráter transitório, em constante mudança, cujas relações sociais onde estão envolvidos os seus atores costumam não depender uma da outra. É suposto que em contatos abertos, o nível de exposição ao $M$. leprae seja menor do que em contatos fechados (Moet et al., 2004).

Em um estudo realizado por Beers et al. (1999), considerando a situação de não contato com doentes de hanseníase como a basal, onde o risco é igual à unidade, foi demonstrado que o risco de contrair a doença ao longo de seis anos foi 9,4 vezes em contatos domiciliares e 3,7 vezes quando do contato na vizinhança; mas quando o contato é multibacilar, o risco no domicílio salta para 13,7 vezes e na vizinhança, para 5,1 vezes. Casos primários não geraram novos casos em $63 \%$ dos paucibacilares e $47 \%$ dos multibacilares. Os casos primários paucibacilares que geraram um caso secundário somaram $29 \%$ e dois casos secundários, $8 \%$. Casos primários multibacilares que geraram um caso secundário foram $24 \%$; dois casos, $22 \%$; e, três casos, $7 \%$. 
Tem sido relatado que o risco de contrair hanseníase está mais associado ao grau de intimidade do contato que ao parentesco familiar do comunicante com as fontes de infecção. Comunicante é um indivíduo que participa da cadeia de transmissão de um agente infeccioso convivendo ou mantendo contato com doentes manifestos ou portadores de patógenos; ou ainda, que tenha tido passagem por ambiente onde permaneceram, recentemente, pessoas com doenças infecciosas (Baldy, 1989). Dentro do domicílio, o grau de intimidade do contato interfere na taxa de ataque de hanseníase, sendo mais alta entre aqueles que compartilham o mesmo dormitório com a fonte de casos; e, quando a mãe, em relação ao pai, é o caso índice (Noordeen, 1994).

É possível contrair hanseníase por meio de contatos eventuais na comunidade. Casos de adoecimento por hanseníase foram descritos durante o seguimento de veteranos de guerra, que retornaram aos seus países não endêmicos, após curta permanência em países endêmicos, onde tiveram contatos casuais com a população nativa (Fine, 1982).

Segundo Hegazy et al. (2002), a hanseníase pode não ocorrer em todas as pessoas infectadas com o M. leprae; e, contatos com bacilíferos nem sempre resultam na transmissão da infecção. Isto é demonstrado pela presença de pessoas clinicamente saudáveis no mesmo agregado familiar de uma pessoa doente.

No entanto, Barreto (2011) encontrou maioria de casos de hanseníase surgidos entre 2 a 19 anos após o caso índice, confirmando que 
o período de incubação da doença pode ser longo, o que reforça a necessidade de seguimento prolongado dos comunicantes.

Em vista da possibilidade de ocorrer casos subclínicos de hanseníase, o alto risco de exposição na população de contatos não deve levar a subestimar a importância da população de não contato. Segundo Noordeen (1994), mesmo em áreas altamente endêmicas, a população de

contatos não ultrapassa $15 \%$ da população total e a estimativa de sua contribuição no total de casos incidentes não chega a $25 \%$; e, os demais casos, provêm da população de não contato, que possuem relativamente um baixo risco de contrair a doença.

\section{Aspectos clínicos}

Atualmente é aceito que a maioria das pessoas tem ou facilmente desenvolvem resistência à infecção pelo M. leprae (Sampaio e Rivitti, 1998), sendo que o fenótipo de susceptibilidade para a infecção pode sofrer influência do hospedeiro, do parasita e das condições ambientais (Camarinha Marcos, 2000).

O M. leprae, após invadir o organismo, atinge os linfonodos pela via linfática e se espalha em infiltrados inflamatórios na pele, mucosas, vísceras e nervos periféricos. Uma desmielinização pode ser encontrada como fenômeno precoce da doença, mesmo em uma fase clínica pouco 
sintomática, quando o bacilo se multiplica na bainha que envolve as fibras nervosas. O dano neural na hanseníase decorre principalmente de alterações patológicas relacionadas à formação de granulomas, edema, compressão de tecidos, isquemia, desmielinização, bloqueio da condução de estímulos nervosos, desenervação e substituição do tecido lesado com proliferação intersticial (Garbino, 2000).

As manifestações clínicas da hanseníase geralmente são insidiosas, não sendo incomum ocorrerem episódios agudos de reações de fundo imunológico (Mendonça et al., 2008). A reação tipo I ou reversa parece ser desencadeada pela multiplicação de bacilos persistentes no organismo, sendo muitas vezes observada concomitante a diabete, gravidez, neoplasia, hepatite, tuberculose, infecção pelo vírus da aids e outras condições que envolvem alterações imunológicas (Opromolla et al., 2000). A multiplicação de bacilos seguida de sua destruição, decorrente da ação imunitária ou terapêutica, libera antígenos desencadeantes de reações de hipersensibilidade do tipo tardias, mediadas por células. A reação do tipo II ou eritema nodoso hansênico, caracteriza uma reação inflamatória sistêmica, envolvendo a formação e depósito de complexos antígenoanticorpo nos tecidos (Goulart et al., 2002). Estes estados reacionais podem trazer graves repercussões tegumentares e viscerais, podendo evoluir concomitantes a neurites e, ainda que raramente, até conduzir ao óbito (Gallo, 2005). 
Os primeiros sintomas da hanseníase podem, muitas vezes, estarem relacionados a uma síndrome tegumentar constituída por máculas hipocrômicas, eritêmato-hipocrômicas ou eritematosas simples; ou por micropápulas liquenóides, com perturbações da sensibilidade superficial, alterações vasomotoras, perda de pêlos e distúrbios da secreção sudorípara, sinais nem sempre percebidos pelos pacientes (Pfaltzgraff e Bryceson, 1985), o que costuma atrasar a apresentação do paciente para o diagnóstico.

O M. leprae apresenta tropismo pelo sistema nervoso periférico, de cujo comprometimento pode resultar neurite, principalmente mononeurites múltiplas, em geral assimétricas (Schnitzler, 1989). No início da doença, os sintomas neurais geralmente são de caráter sensitivo, ramuscular e superficial; alterações motoras, tronculares e distais são tidas como sendo tardias (Pfaltzgraff e Bryceson, 1985), sendo adequado o teste da sensibilidade tátil, térmica e dolorosa da pele para o diagnóstico precoce da doença (Leiker, 1977).

$\mathrm{Na}$ suspeição de hanseníase, o diagnóstico clínico pode ser corroborado por provas como a da histamina e da pilocarpina, exames baciloscópicos de raspado intradérmico e pela verificação histológica de material obtido de biopsias de pele (Sampaio e Rivitti, 2000).

Existem vários sistemas classificatórios para direcionar a escolha do regime terapêutico a ser adotado, predizer o grau de infecciosidade e estabelecer um prognóstico de incapacidades. Embora a base de todos eles 
seja a clínica, levam também em conta os achados bacteriológicos, imunológicos e histopatológicos (Jopling, 1991).

Nas manifestações de resistência à infecção, clinicamente indeterminadas, com raros bacilos, os danos neurais são incipientes, restringindo-se a filetes nervosos, capilares e anexos cutâneos ao redor das terminações nervosas, onde uma inflamação do tipo granulomatosa se relaciona com o grau de resistência à infecção. Na hanseníase tuberculóide, os aspectos predominantes de poucas lesões e raros bacilos refletem uma forte resposta imune mediada por células, resultando muitas vezes na destruição de bacilos e tecido neural (Souza, 1997).

Em outro pólo do espectro clínico situa-se a forma virchowiana, relacionada à ausência de resposta imune mediada por células. É uma forma clínica multibacilar, altamente contagiante, sendo comum provocar lesões disseminadas e nodulares (Dharmendra, 1985).

$\mathrm{Na}$ forma multibacilar dimorfa ou interpolar, a resposta imunológica é instável e a doença se expressa clinicamente com lesões maculares ou máculo-papulares, circunscritas ou difusas, muitas vezes concorrentes. É comum nesta apresentação borderline haver modificação do padrão clínico, isto ocorrendo silenciosamente ou acompanhada de reações antigênicas danosas aos nervos (Naafs, 2000).

São de uso comum as formas simplificadas de classificação clínica da doença, que privilegiam o aspecto operacional, ao propiciar um rápido reconhecimento do grau de resistência desenvolvido pelo paciente (OMS, 
1989). O encontro de poucas lesões, como no máximo cinco; lesões de tamanho pequeno, com margens bem definidas e bordas elevadas; marcada despigmentação dérmica; lesões deprimidas na parte central e com superfície de aspecto papuloso são sugestivas de formas de alta resistência e escassa presença bacilar, sendo estes casos classificados como paucibacilares. O achado de cinco ou mais lesões planas, extensas e de limites imprecisos ou nódulos disseminados, sugere baixa resistência à multiplicação bacilar, que pode corresponder a formas multibacilares de manifestação da doença.

A doença não tratada pode evoluir com fraqueza e anestesia de mãos e pés; cegueira; destruição nasal, palatal e auricular; osteoartropatias; deformidades dos membros; e, déficits neurológicos periféricos. Estas alterações muitas vezes repercutem no indivíduo doente enquanto sofrimento físico, psíquico e exclusão social (Duerksen, 2000).

A deficiência na imunidade celular é considerada determinante para a expressão clínica da doença (Jopling, 1991). Para compor o quadro de informações que auxiliam na classificação da doença no seu espectro de atividade, tem sido utilizado o teste de Mitsuda. Esta prova in vivo avalia a resistência do hospedeiro e baseia-se em uma reação de hipersensibilidade tardia, um tipo de resposta imune específica mediada por células. A sua positividade pode não se traduzir em proteção eficaz contra a infecção (Bechelli e Curban, 1978), mas é muito útil para traçar um prognóstico clínico, quando da doença. 
Abraão Rotberg (1912 - 2006) elaborou a teoria patogenética do "Fator-N/Margem Anérgica", inicialmente apresentada em 1937 (Rotberg, 1977), postulando a hipótese de que todos os indivíduos nascem Mitsudanegativos, mas gradativamente se tornam Mitsuda-positivos, após estímulos micobacterianos e por outros agentes desconhecidos; uma minoria restante, sem "Fator-N", permaneceria na "Margem Anérgica", sendo Mitsudanegativo pelo resto da vida (Beiguelman, 2002).

Atualmente a hanseníase pode ser curada do ponto de vista bacteriológico. O tratamento é realizado em regime ambulatorial e as internações costumam se restringir aos episódios reacionais graves. É recomendada uma combinação de drogas antimicrobianas que visa prevenir a resistência medicamentosa, diminuir rapidamente a carga bacilar e interromper a transmissão. Para as formas multibacilares é indicada a rifampicina, clofazimina e dapsona durante 12 meses; e, para as formas paucibacilares, a rifampicina e a dapsona por seis meses (Opromolla, 1997). A rifampicina é bactericida e deve ser tomada em doses mensais e as demais medicações, bacteriostáticas, diariamente. Este esquema terapêutico vem demonstrando ser bem tolerado pelos pacientes, seguro e associado a uma baixa taxa de recidiva (Petri e Oyafuso, 2003); esta poliquimioterapia interrompe a contagiosidade do doente no primeiro mês de tratamento e quando instituída em fase precoce da doença, pode contribuir para mitigar danos neurais. 
O grau mínimo de sequela pode ser considerado como sendo uma anestesia localizada. Apenas o grupo indeterminado, na fase inicial, adequadamente tratado, não deixa nenhuma sequela. O diagnóstico tardio e o tratamento irregular são comuns em nosso meio e a maioria dos diagnósticos é feito quando o paciente já apresenta algum grau de incapacidade física (Margarido-Marchese et al., 1996).

Há evidências de que a aplicação de vacina BCG intradérmica, ao estimular a imunidade celular, pode proteger contra o desenvolvimento de formas multibacilares, mas não evita a doença, sendo atualmente indicada na profilaxia de contatos (Ura e Opromolla, 2000).

\section{Aspectos Epidemiológicos}

É suposto que a distribuição da hanseníase esteja condicionada por uma associação de fatores ambientais e biológicos, alguns relacionados a oportunidades de exposição e outros a predisposição genética. A ocorrência da hanseníase é comumente referida a contextos de carência social, onde fatores socioeconômicos desempenhariam um papel importante. Costumase creditar ao desenvolvimento social das populações da Europa e do Japão o declínio da hanseníase ocorrido no passado (Noordeen, 1994). No entanto, é lembrado que os componentes críticos do contexto 
socioeconômico que influenciam a ocorrência da doença, ainda não são conhecidos em detalhe (Moet, 2004).

Observa-se que as regiões tropicais e subtropicais concentram a maioria dos países endêmicos da atualidade; e, sendo justamente nestes onde coexistem pobreza, má higiene e desinformação, é intuitivo pensar que a ocorrência da hanseníase seja influenciada pelo meio ambiente e comportamento dos indivíduos, que são fatores permeados pelo desenvolvimento social (Bechelli, 1991; Bryceson, 1992).

Neste sentido, o declínio da hanseníase poderia advir de melhorias no padrão de vida; na distribuição da riqueza; na sanidade do meio, especialmente a da moradia; e, na eficiência dos agentes utilizados para o controle da doença.

Um risco mais alto para hanseníase foi observado entre indivíduos não escolarizados, lavradores, operários, moradores em domicílios com baixa insolação e aqueles sob precárias condições de higiene, no domicílio ou no bairro (Kumar et al., 2001).

Em um estudo realizado na Índia envolvendo 12 agregados de área, a desnutrição de crianças de um a quatro anos de idade mostrou significante correlação positiva com a prevalência de hanseníase (Sommerfelt, 1985).

Padrões de distribuição da doença considerados inerentes a susceptibilidade individual podem também estarem ligados a intensidade da exposição, muitas vezes vinculada a padrões sociológicos de interação. $\mathrm{Na}$ Noruega, a hanseníase foi mais prevalente na área costeira, onde morava 
cerca da metade da população do país, e especialmente nas localidades onde o tráfego marítimo de passageiros era mais extenso. A maioria da população destes lugares se ocupava com a pesca, o que implicava permanência por vários meses ao ano em contato fechado e em precárias condições de higiene (Irgens, 1981).

Para outros, a taxa de disseminação da hanseníase depende, primordialmente, da proporção de indivíduos susceptíveis na população e da presença de portadores de formas contagiantes da doença, que ficam por longo tempo sem tratamento (Bullock, 1979).

Casos subclínicos representam uma fração maior em relação à de doentes no total de infectados (Harboe, 1985). A positividade da reação de Mitsuda, que reflete o grau de resistência inato ou adquirido, aumenta com a idade e chega a atingir $90 \%$ da população adulta em lugares endêmicos (Sampaio e Rivitti, 1998).

Fatores genéticos têm sido investigados na susceptibilidade à hanseníase. Observou-se que se um gêmeo tem hanseníase, a chance de outro gêmeo adoecer é de $60 \%$ a $85 \%$ para gêmeos monozigóticos e de $15 \%$ a 25\% para dizigóticos (Meyers, 1995). Foi demonstrado o caráter familial do resultado da reação de Mitsuda, sendo provável que a susceptibilidade aos subtipos da doença seja controlada por um conjunto de genes recessivos (Feitosa et al., 1995; Beiguelman, 1999).

Fatores de susceptibilidade genética influenciando a infecção provavelmente são independentes daqueles que determinam a manifestação 
da doença; fazendo da hanseníase, enquanto doença, algo em separado, mas decorrente de um mesmo processo endêmico que é mais extenso, enquanto fenômeno populacional. A estrutura genética do hospedeiro tem influência sobre o tipo de enfermidade que se produz após a infecção, ao modular a resposta imunológica específica pela presença do Mycobacterium leprae, por meio de fatores ligados ao complexo maior de histocompatibilidade (Geluk e Ottenhoff, 2006). Em uma situação de expansão da endemia, é esperado que a forma tuberculóide, que é a expressão de uma resposta imune celular competente (Bullock, 1978; Godal, 1984), venha a torna-se mais frequente (Albuquerque et al., 1989).

Apesar da prevalência da hanseníase ter diminuído drasticamente em todo o mundo, é preocupante o fato de alguns países não experimentarem declínio da incidência na mesma intensidade, mesmo tendo instituído, por longo tempo, programas de controle baseados no diagnóstico precoce (Beers et al., 1994; Ramaprasad, 1997).

A contribuição dos casos subclínicos no ciclo de transmissão da hanseníase permanece não esclarecida. Alguns autores advogam que as fontes subclínicas são tão importantes para a manutenção da endemia quanto os casos manifestos; em uma fase patogênica localizada, a infecção teria um caráter transitório, resultando na circulação do agente no ambiente, muito mais do que em doença para o hospedeiro. Em áreas endêmicas, a maioria da população possui evidência imunológica de exposição ao $M$. 
leprae, inclusive nos lugares onde casos virchowianos são raros (Cree e Smith, 1998).

A partir de evidências de que a infecção inicial pelo $M$. leprae ocorre na mucosa da cavidade nasal, tem sido investigada a imunidade específica desenvolvida no nível das mucosas, enquanto primeira linha de proteção. Acredita-se que anticorpos específicos encontrados em secreções respiratórias poderiam oferecer proteção específica de curta duração, a cada estímulo antigênico do $M$. leprae (Pallen e McDermott, 1986; Smith et al., 2004)

Verifica-se ampla variação geográfica na proporção das formas virchowianas entre as diferentes partes do mundo. Em algumas populações da Ásia, $50 \%$ ou mais dos doentes apresentam formas virchowianas, enquanto que, na África, esta ocorrência chega a estar abaixo de 10\% dos casos incidentes (Meyers, 1984).

Relação entre grupo étnico e tipo de expressão clínica da hanseníase foi verificada, sendo que europeus e chineses são tidos como pertencentes ao grupo de alta susceptibilidade às formas virchowianas da doença, quando comparados a africanos e indianos (Bullock, 1979; Pfaltzgraff e Bryceson, 1985).

É reconhecido que a hanseníase incide mais frequentemente em clusters, fenômeno particularmente descrito em áreas de baixa prevalência e relacionado a casos entre familiares. Fatores ambientais e genéticos são difíceis de serem dissociados nos casos que ocorrem dentro de uma mesma 
família. O risco de adoecimento no ambiente familiar tem sido mais relacionado ao grau de intimidade do contato, que à proximidade familial com a fonte de infecção (Noordeen, 1994).

A hanseníase acomete todas as idades. Não é considerado incomum a doença iniciar após os 70 anos de idade. Há relato de casos diagnosticados antes do término do primeiro ano de vida, mas não há evidências de que exista relação entre idade e prognóstico da doença (Pfaltzgraff e Bryceson, 1985). A taxa de detecção de hanseníase em menores de 15 anos indica transmissão recente por fontes ativas e está relacionada com a intensidade da exposição ambiental ao $M$. leprae e com a qualidade da atenção à saúde (Flach et al., 2010).

Uma tendência comumente observada em hanseníase é o excesso de casos entre adultos, relativamente a crianças (Rao et al., 1972). Em uma situação endêmica, presume-se que a probabilidade de exposição aumente com a idade, devido à duração da exposição, e com a intensidade dos fatores ambientais, como a prevalência de contagiantes (Irgens, 1985). Na China, em uma fase de declínio da endemia, observou-se um aumento de oito a dez anos na idade média de início da doença, em um prazo de três décadas (Huan-Ying, 1985).

Em um estudo realizado na Noruega, a distribuição da hanseníase por idade foi analisada pelo encadeamento de coortes de nascimento. $\mathrm{O}$ pico de incidência encontrado para cada coorte recaiu sobre o grupo de 15 a 29 anos, resultado consistente com a explicação de que a hanseníase tem 
um período de incubação variável, com aumento da proporção de pacientes com longo período de incubação durante a tendência de declínio da endemia; e, não propriamente, devido um deslocamento do risco de infecção para idades mais avançadas (Irgens, 1980).

No Brasil, a prevalência da hanseníase tem sido descrita como sendo maior no sexo masculino (Bechelli e Curban, 1978; Ministério da Saúde, 2008a). Em alguns países da África a prevalência da doença entre os sexos se iguala ou até se mostra mais alta no sexo feminino (Noordeen, 1994). No sexo feminino parece haver uma resposta imune mais efetiva contra a infecção pelo M. leprae no nível subclínico (Ura e Opromolla, 2000).

Em geral, entre sexos, a prevalência da hanseníase em adultos é encontrada como sendo duas vezes maior no sexo masculino em relação ao sexo feminino; mas, em crianças ou jovens, esta relação pode chegar a 1:1 (Meyers, 1995). Viés de gênero pode ter importantes repercussões na detecção, tratamento e controle da hanseníase. Na Índia, o impacto da hanseníase na vida social é maior para as mulheres (Rao et al., 1996). No Brasil, as repercussões psico-afetivas da hanseníase parecem ser mais importantes entre mulheres (Oliveira e Romanelli, 1998).

Para Irgens e Skjaerven (1985), padrões sociológicos condicionam a exposição, podendo resultar em diferentes distribuições por sexo. Em situações de baixa prevalência, a relevância da infecção adquirida na comunidade costuma aumentar relativamente à infecção adquirida no ambiente doméstico. 
Para uma mesma área geográfica, podem ser encontradas diferenças étnicas na distribuição da hanseníase por idade e sexo. Em um estudo realizado na América do Norte, a ocorrência de hanseníase em imigrantes foi maior entre os mais jovens, enquanto nos nativos se deu o inverso (Neill et al., 1985).

Em um estudo realizado na África, a relação entre hanseníase e fatores climáticos, como temperatura e umidade, mostrou-se fraca (Hunter e Thomas, 1984). No Nordeste brasileiro é marcante a diferença entre a incidência da hanseníase no sertão semi-árido e no litoral úmido, lugares que passaram por distintos processos de ocupação e organização espacial (Magalhães e Rojas, 2007).

Migrações são citadas como fator que pode aumentar ou diminuir artificialmente a prevalência de hanseníase em algumas áreas ou introduzir doentes em áreas não afetadas. No entanto, a introdução esporádica de casos importados de hanseníase não tem produzido casos secundários em países não endêmicos (Noordeen, 1994). 


\subsection{A Hanseníase Endemia}

\section{Endemia de Hanseníase no Mundo}

Nas duas últimas décadas do século $X X$, as estatísticas da hanseníase declinaram em todo o mundo. O número de doentes em tratamento, que era de 12 milhões ao final da década de 1970, passou em 1993 à cifra de 2,4 milhões (Noordeen, 1995).

Em 1981, um grupo de estudos sobre quimioterapia na hanseníase, patrocinado pela OMS, recomendou o uso de uma poliquimioterapia - PQT, baseada em três drogas - rifampicina, clofazimina e dapsona para o tratamento da doença (Nogueira e Marziliak, 1997).

Com o êxito da PQT, a 44a Assembleia Mundial da Saúde, em 1991, aprovou uma resolução declarando o compromisso de eliminar a hanseníase como problema de saúde pública, direcionando esforços para alcançar uma prevalência inferior a 1,0 caso de hanseníase para cada 10.000 habitantes em cada país endêmico (World Health Organization - WHO, 1995). No ano 2000, em termos globais, a hanseníase já apresentava uma prevalência abaixo do patamar de eliminação (WHO, 2002).

O "controle" epidemiológico de uma enfermidade transmissível é definido como sendo a redução da carga de doença para um nível aceitável localmente. "Eliminação" da doença é considerada quando da redução a 
zero da incidência em uma determinada área geográfica e "erradicação" seria a redução permanente a zero da incidência mundial de infecção causada por um agente específico (Richardus e Habbema, 2007). O conceito de "eliminação" da hanseníase adotado pela OMS pressupõe que abaixo da prevalência de 1,0 caso / 10 mil habitantes as infecções diminuiriam na população (OMS, 2000).

Segundo a OMS (2005), em todas as regiões afetadas pela hanseníase houve um aumento considerável na cobertura dos serviços em áreas remotas e junto a populações marginalizadas; e, em 1995, cerca de 3/4 dos doentes em tratamento já estavam sob a PQT e todos os países endêmicos já disponibilizavam de forma gratuita os medicamentos aos doentes, por intermédio de filantropia internacional.

Entre as mudanças nos programas de controle que acompanharam a introdução da PQT, podem ser citados o critério de alta, a duração do tratamento e o método de cálculo da prevalência, que passou a ser apurada "no ponto" e não mais como sendo a prevalência anual. Todos estes fatores contribuíram para que a prevalência sofresse uma drástica diminuição estatística (WHO, 1995). Para a alta por cura atualmente é recomendado completar a PQT em no mínimo seis e no máximo nove meses, para casos paucibacilares; e, de 12 a 18 meses, para multibacilares. Na fase anterior, de monoterapia, doentes multibacilares poderiam receber a recomendação de permanecer cronicamente em tratamento, o que significava a não saída destes da estatística de casos ativos. 
Em diversos países endêmicos a redução da carga de doença e da morbidade da hanseníase tem sido colocada entre as principais metas na área da Saúde. Entre 1985 e 2004, mais de 14 milhões de casos de hanseníase foram diagnosticados e completaram um curso de tratamento poliquimioterápico, tendo sido notificados, entre os anos de 2005 e 2008, de dois a três mil casos de retratamento, distribuídos em 40 países. Em 2008, o número de casos em tratamento ao final do ano era de 213 mil e em 2009 houve uma redução de $0,5 \%$ em relação ao ano anterior. A detecção de 560 mil casos no ano de 1994, quando comparada com a de 249 mil casos alcançada em 2008, mostra que, em termos mundiais, este indicador também vem declinando, embora em um ritmo muito mais lento que o observado para o número de casos prevalentes (WHO, 2009).

Em 1985, o número de países que notificaram coeficientes de prevalência acima da meta de eliminação estipulada pela OMS de 1,0 caso / 10.000 hab. foi de 122 países. A fase de eliminação da endemia é considerada uma etapa sanitária do programa de controle em que se supõe que a doença esteja se reproduzindo na população em uma taxa abaixo da unidade; mas para garantir a manutenção da morbidade em níveis decrescentes é indicado um contínuo aprimoramento das atividades de vigilância, mesmo após o alcance da eliminação. Até 2008, três países com população acima de um milhão de habitantes permaneciam acima da meta de eliminação (Figura 1.1): Brasil, Nepal e Timor-Leste (WHO, 2008). 
Nota-se um importante contraste na distribuição geográfica da hanseníase no mundo, onde países da Europa e Canadá, não têm apresentado casos autóctones, enquanto muitos países do cinturão equatorial convivem com a doença, destacadamente, o Brasil e a Índia (Figuras 1.2). Dos casos de hanseníase detectados em 2008, o Sudeste Asiático reuniu 67\% deles, seguido pelas Américas com 17\%, África com $12 \%$ e o restante do mundo com cerca de $4 \%$ (WHO, 2009).

No ano de 2008, na África, a taxa de detecção de casos de hanseníase com incapacidades físicas severas ao diagnóstico, foi de 0,51 casos / 10.000 hab., o dobro da taxa mundial. Dezessete países reportaram um número igual ou superior a mil casos no ano, somando $94 \%$ da incidência global. Mais de $80 \%$ dos casos são cotados a cinco países: Índia, 54\%; Brasil, 16\%; Indonésia, 7\%; Congo, 3\%; e Bangladesh, 2\% (WHO, 2009).

Nas Américas, em 2008 a prevalência de hanseníase foi de 0,54 casos / 10.000 hab. e foram diagnosticados 41.891 pacientes, perfazendo uma taxa de detecção de 0,49 casos / 10.000 hab., sendo que o Brasil foi o maior contribuinte à carga da doença, onde foram registrados $93 \%$ dos diagnósticos do Continente (WHO, 2009).

Meima et al. (2004), observaram que no período de 1994 a 2000 houve um declínio anual do número de casos de hanseníase detectados mundialmente, embora não para todos os países endêmicos. A tendência da 
taxa de detecção de casos no mundo mostra decréscimo de 2002 a 2008 (WHO, 2009).

Segundo Lockwood e Suneetha (2005), na Índia, país que apresenta o maior número de casos, no período de 1982 a 2002, o coeficiente de detecção esteve aumentando constantemente.

Figura 1.1 (WHO, 2010). Taxa de prevalência de hanseníase calculada com dados notificados à OMS. Janeiro, 2009

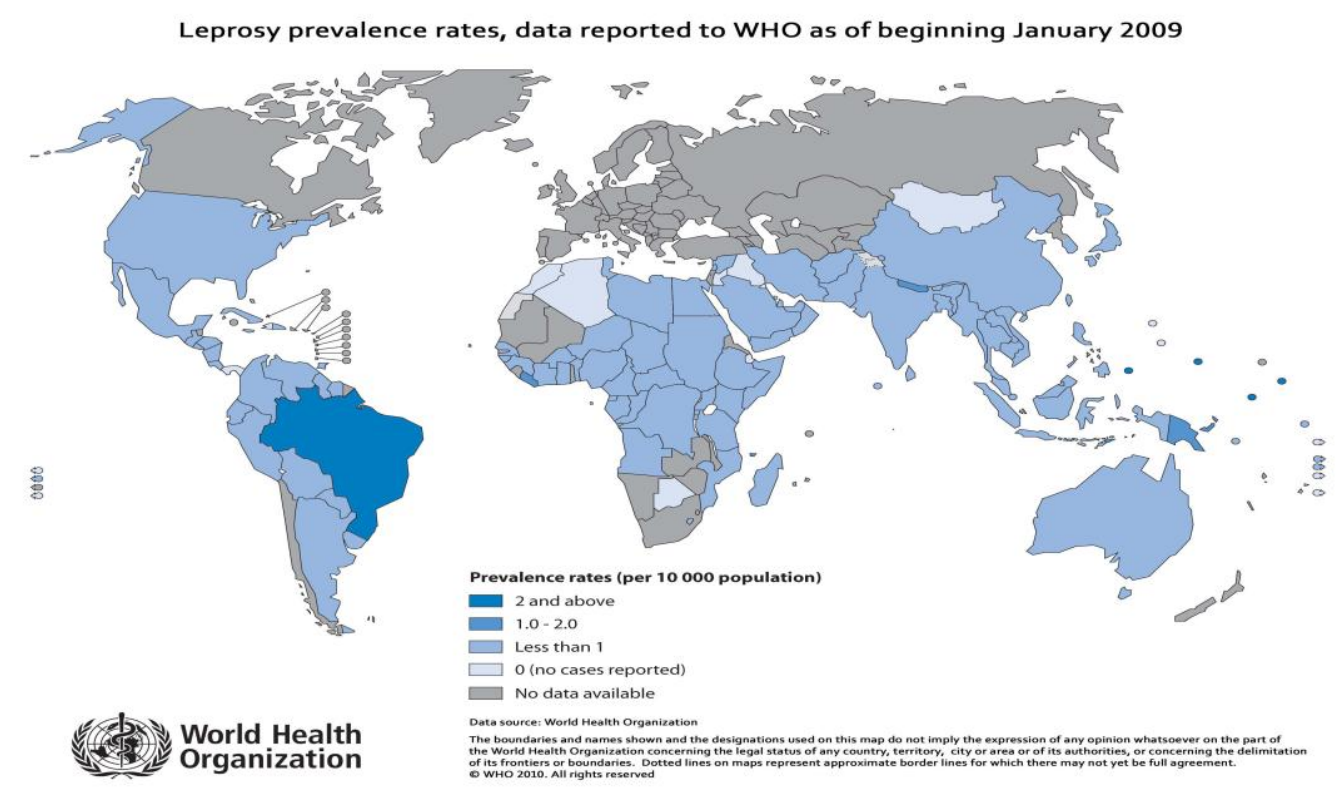

FONTE: Organização Mundial da Saúde - OMS (adaptado) 
Figura 1.2 (WHO, 2010). Taxa de detecção de casos diagnosticados recentemente de hanseníase calculada com dados notificados à OMS. Janeiro, 2009

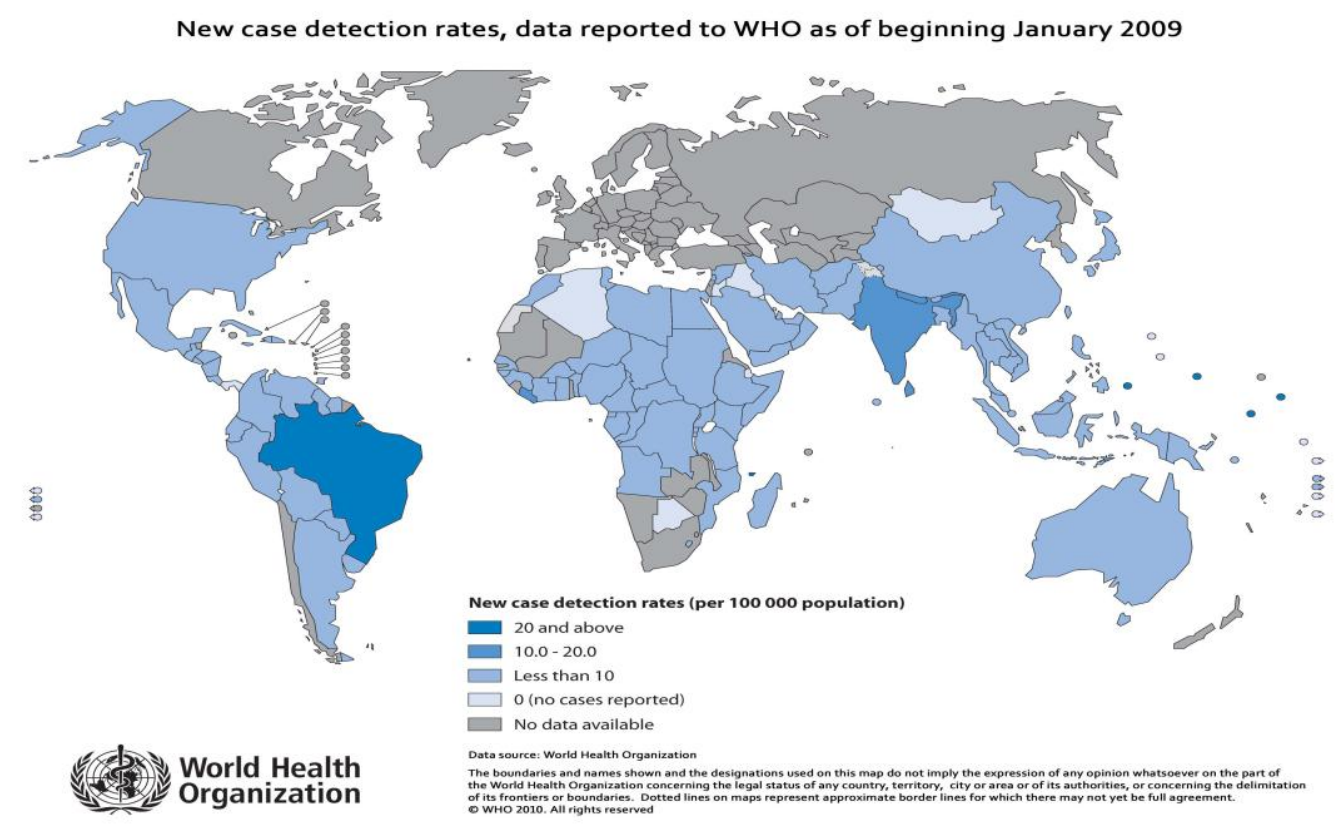

FONTE: Organização Mundial da Saúde - OMS (adaptado)

Somente $1 / 3$ da população mundial não mora em países endêmicos, fato que convida a analisar com cautela as comparações de taxas de detecção de casos entre países. Países com grandes denominadores populacionais podem apresentar baixas taxas de detecção, ao mesmo tempo em que, anualmente, um considerável contingente populacional afetado pela doença se renova (Meima et al., 2004).

Devido ao longo período de incubação da hanseníase, os dados sobre o impacto da PQT na transmissão não estão facilmente disponíveis. Segundo Richardus e Habbema (2007), a modelagem matemática da transmissão e do controle da doença evidenciou que a estratégia de 
eliminação reduz a transmissão, mas de maneira lenta e com uma previsão de declínio anual em um largo intervalo, desde $2 \%$ a $12 \%$; sendo a descoberta precoce de casos um fator decisivo para atingir este declínio. Projeções sobre o ônus da hanseníase no mundo indicaram que cinco milhões de novos casos estariam surgindo entre os anos de 2000 e 2020; e, ao final deste período, haveria um milhão de pessoas com incapacidade física grave, decorrente da doença. Embora tenha havido melhorias substanciais no controle, a hanseníase ainda não foi definitivamente eliminada, o que demandaria encontrar intervenções eficazes para interromper a transmissão do $M$. leprae e ferramentas de diagnóstico para detectar níveis de infecção perpetuadoras da transmissão; o que, segundo os autores, exige uma extensa pesquisa nas áreas de epidemiologia e microbiologia.

\section{A Endemia de Hanseníase no Brasil}

No Brasil, a endemia de hanseníase é considerada um importante problema de Saúde Pública pela sua magnitude e transcendência. Em 1993 foram detectados 34.235 casos de hanseníase no país (WHO, 2008).

Os primeiros ensaios terapêuticos com a PQT começaram no Brasil em 1982. Em 1987 o Ministério da Saúde iniciou sua implantação gradual, o que exigiu o treinamento de um grande número de técnicos, até que em 1991, a PQT passou a vigorar como regime único de tratamento, 
recomendado pela Divisão Nacional de Dermatologia Sanitária. A proporção das saídas do registro ativo por alta por cura passa de $24 \%$, em 1987, para 59\% em 1991 (Andrade, 2006).

Ao longo de 2007, tinham sido detectados 39.125 casos da doença, resultando em uma taxa de deteç̧ão de 2,05 casos/10.000 hab.; e, ao final de 2007 estavam em registro ativo no país 45.847 pacientes em tratamento, correspondendo a uma taxa de prevalência de 2,40 casos/10.000 hab. (WHO, 2009).

Em 2009, o Brasil apresentou a maior taxa de detecção de hanseníase do mundo, sendo que dos 37.610 casos diagnosticados naquele ano, $21.414(56,9 \%)$ eram multibacilares; 16.865 (44,8\%) no sexo feminino; $2.669(7,1 \%)$ em crianças abaixo de 15 anos de idade; 2.436 (6,5\%) apresentavam grau severo de incapacidade física ao diagnóstico. A taxa de cura situou-se entre $85 \%$ para paucibacilares e $80 \%$ em multibacilares (WHO, 2010).

O coeficiente de detecção anual de casos novos de hanseníase tem sido utilizado para determinar a tendência e avaliar as mudanças na situação da hanseníase ao longo do tempo. O Ministério da Saúde (Brasil, 1989) considera, para a interpretação deste indicador, as seguintes margens de endemicidade por 10 mil habitantes: <0,2 - Baixa; de 0,2 a < 1,0 - Média; de 1,0 a $<2,0$ - Alta; de 2,0 a < 4,0 Muito alta; 4,0 e mais - hiperendêmica.

Embora a hanseníase apresente tendência de queda dos coeficientes de detecção no Brasil como um todo, este indicador se mostra ainda em 
patamares elevados nas regiões Norte, Centro-Oeste e Nordeste, onde apresenta marcada correspondência territorial entre nível de endemicidade e Índice de Desenvolvimento Humano - IDH (Brasil, 2010). Magalhães e Rojas (2007) levantaram as seguintes taxas macrorregionais de detecção de casos de hanseníase (por 10 mil hab.) para o Brasil, em 2002: 7,73 no Norte; 6,61 no Centro-Oeste; 3,23 no Nordeste; 1,46 no Sudeste; e 0,75 no Sul.

A taxa de detecção de hanseníase também tem variado amplamente entre os estados. Tomando-se o período de 2001 a 2005, aqueles com as maiores taxas de detecção média anual de casos foram Roraima e Mato Grosso. Apenas os estados de São Paulo, Rio Grande do Sul e Santa Catarina aparecem com prevalência abaixo de 1,0 caso para cada 10.000 habitantes. Nota-se que dos estados amazônicos, somente Amapá e Amazonas não apresentaram níveis hiperendêmicos, mesmo assim, estiveram muito próximos desta marca; Pará e Maranhão tiveram os maiores números absolutos de casos do país (Tabela 1.1).

No Maranhão, Figueiredo e Silva (2003) encontraram, em 1998, uma taxa de detecção de hanseníase de 7,9 casos por 10 mil habitantes; Façanha et al. (2006), no Ceará, em 2000, levantaram a taxa de 3,7; Mastrangelo et al. (2009), no Piauí, em 2002, constataram a taxa de 5,5; Pimentel (2004), em 2003, no Rio de Janeiro, 2,14; Silva Sobrinho e Mathias (2008), para o Paraná, em 2005, uma taxa de 1,60; Opromolla e Laurenti (2011), em 2007, para o estado de São Paulo, obtiveram 0,49 casos por 10 mil habitantes. 
Entre 1997 e 2006 foram registrados no Brasil 379 mil casos de hanseníase (Brasil, 2008b). A distribuição destes casos por município de residência pode ser vista no Mapa 1.1. Extensos conglomerados de municípios com mais de 100 casos de hanseníase diagnosticados entre residentes, neste período de dez anos, pode ser visto predominando na região amazônica.

Entre 2001 e 2005, 85\% dos municípios brasileiros registraram algum caso de hanseníase entre residentes e 15\% não registraram nenhum caso. Quarenta e três por cento dos municípios registraram mais de 10 casos e 8\% mais de 100 casos da doença (Brasil, 2008b).

Somente no ano de 2006 foram diagnosticados 44.538 casos de hanseníase (Brasil, 2008b). Municípios com taxa de detecção igual ou superior a 10 casos de hanseníase por 10 mil hab. representavam 6\%. Aqueles com 1,0 a menos de 10,0 casos por 10 mil hab. somaram $39 \%$. Os municípios com detecção não nula e menor que 1,0 caso por 10 mil hab. perfizeram $14 \%$ e os que não registraram casos de hanseníase entre residentes, estiveram em $41 \%$.

Nos limites da Amazônia legal brasileira estão concentrados municípios que possuem alta incidência de hanseníase, conformando a maior área contígua de hiperendemicidade do país, que inclui praticamente todo o estado do Mato Grosso e extensas áreas do Tocantins, Pará, Maranhão, Roraima, Amazonas, Acre e Rondônia (Mapa 1.2). Municípios das Regiões Norte e Centro-Oeste do Brasil se destacam pela grande 
extensão territorial, baixa densidade demográfica e proporção da população em situação rural de domicílio, relativamente elevada em comparação com o restante do país.

Segundo Motta e Zuniga (1990), no Brasil como um todo, de 1950 a 1968, a taxa de detecção de hanseníase apresentou um pequeno decréscimo, que os autores atribuem em parte a fatores operacionais que influenciaram a detecção de casos.

Entre 1969 e 1987, a taxa de detecção teve aumento anual, sendo que as mais altas taxas de detecção foram encontradas nas regiões Norte e Centro-Oeste e os maiores incrementos médios anuais no Nordeste e Centro-Oeste.

Andrade (1996) encontrou aumento dos coeficientes brutos de detecção de hanseníase no Brasil entre os anos 1985 e 1994, o que imputou a variações do padrão de transmissão e a mudanças operacionais do programa de controle da doença, tal como a melhoria do registro de casos e da capacidade diagnóstica da rede assistencial. Para o período de 1990 a 1994 foram distinguidos padrões endêmicos entre as unidades federadas, levando-se em conta indicadores da magnitude e precocidade da exposição ao $M$. leprae. Com estes parâmetros, uma área englobando 14 estados foi classificada como sendo "prioritária" para ações de controle, estando o Mato Grosso entre eles, inclusive com características de expansão endêmica. 
Tabela 1.1 - Taxa de detecção média anual de casos de hanseníase (TDMA), Brasil, Unidades da Federação - 2001 a 2005

\begin{tabular}{|c|c|c|c|c|c|}
\hline \multirow{2}{*}{$\begin{array}{l}\text { Unidade da } \\
\text { Federação }\end{array}$} & \multicolumn{2}{|c|}{ População } & \multicolumn{2}{|c|}{ Casos detectados } & \multirow{2}{*}{$\begin{array}{c}\text { TDMA } \\
\text { (casos/10.000 } \\
\text { hab.lano) }\end{array}$} \\
\hline & $\mathbf{n}$ & $\%$ & $\mathbf{n}$ & $\%$ & \\
\hline Roraima & 357.296 & 0,20 & 2.738 & 1,09 & 15,33 \\
\hline Mato Grosso & 2.651 .313 & 1,50 & 17.776 & 7,07 & 13,41 \\
\hline Tocantins & 1.230 .188 & 0,70 & 5.972 & 2,38 & 9,71 \\
\hline Pará & 6.574 .990 & 3,72 & 29.178 & 11,61 & $\mathbf{8 , 8 8}$ \\
\hline Maranhão & 5.873 .646 & 3,32 & 26.010 & 10,35 & 8,86 \\
\hline Rondônia & 1.455 .914 & 0,82 & 6.426 & 2,56 & 8,83 \\
\hline Goiás & 5.306 .424 & 3,00 & 17.280 & 6,88 & 6,51 \\
\hline Acre & 600.607 & 0,34 & 1.857 & 0,74 & 6,18 \\
\hline Piauí & 2.923.695 & 1,65 & 8.790 & 3,50 & 6,01 \\
\hline Espírito Santo & 3.250 .205 & 1,84 & 8.142 & 3,24 & 5,01 \\
\hline Pernambuco & 8.161 .828 & 4,61 & 17.008 & 6,77 & 4,17 \\
\hline Amazonas & 3.031 .079 & 1,71 & 6.045 & 2,41 & 3,99 \\
\hline Ceará & 7.758 .437 & 4,39 & 14.097 & 5,61 & 3,63 \\
\hline Amapá & 534.821 & 0,30 & 867 & 0,35 & 3,24 \\
\hline Mato Grosso do Sul & 2.169 .704 & 1,23 & 3.253 & 1,29 & 3,00 \\
\hline Sergipe & 1.874 .597 & 1,06 & 2.606 & 1,04 & 2,78 \\
\hline Paraíba & 3.518 .607 & 1,99 & 4.664 & 1,86 & 2,65 \\
\hline Bahia & 13.440 .544 & 7,60 & 15.866 & 6,31 & 2,36 \\
\hline Rio de Janeiro & 14.879.144 & 8,41 & 15.959 & 6,35 & 2,15 \\
\hline Paraná & 9.906 .812 & 5,60 & 8.565 & 3,41 & 1,73 \\
\hline Minas Gerais & 18.553.335 & 10,49 & 15.959 & 6,35 & 1,72 \\
\hline Alagoas & 2.917 .678 & 1,65 & 2.213 & 0,88 & 1,52 \\
\hline Distrito Federal & 2.189 .792 & 1,24 & 1.627 & 0,65 & 1,49 \\
\hline Rio Grande do Norte & 2.888 .087 & 1,63 & 1.596 & 0,64 & 1,11 \\
\hline São Paulo & 38.709.339 & 21,88 & 14.526 & 5,78 & 0,75 \\
\hline Santa Catarina & 5.607 .160 & 3,17 & 1.117 & 0,44 & 0,40 \\
\hline Rio Grande do Sul & 10.511.009 & 5,94 & 1.167 & 0,46 & 0,22 \\
\hline TOTAL & 176.876 .251 & 100,00 & 251.304 & 100,00 & 2,84 \\
\hline
\end{tabular}

FONTE: Estimativas populacionais - Intituto Brasileiro de Geografia e Estatística (IBGE), Dados epidemiológicos - Ministério da Saúde, Departamento de Informática do Sistema Único de Saúde (Datasus), Sistema de Informação de Agravos de Notificação (SINAN)

NOTA: A TDMA foi calculada pela soma do número de casos diagnosticados recentemente, registrados entre os anos de 2001 e 2005, multiplicado por 10 000, dividido por 5 e pela população do ano de 2003 
Magalhães e Rojas (2007) constataram que a endemia de hanseníase no Brasil, entre 1998 a 2002, esteve em expansão a partir de focos nas Regiões Norte, Centro-Oeste e Nordeste e associada às frentes de colonização agrícola da Amazônia e ao crescimento urbano das regiões metropolitanas.

Penna M. e Penna G. (2007), demonstraram que no Brasil, na série histórica de 1980 - 2005, as taxas anuais de detecção de hanseníase estavam ascendendo, porém, em crescimento desacelerado. A predição do ponto de inflexão da taxa de incidência indicava o ano de 2010. Em outro estudo, Penna G. et al. (2009), apontam que em 2006 a taxa de incidência de hanseníase no Brasil mostra sinal de estagnação, mas não descartam que isto possa ter sido reflexo de contingências na atividade de detecção. Na região amazônica, ao final do período de 2001 - 2006, a taxa de incidência de hanseníase parece começar a declinar, mas é notado que indivíduos de classes socioeconômicas mais baixas, com educação formal insuficiente, foram mais afetados que outros grupos populacionais; sendo que estes diferenciais epidemiológicos entre os estratos sociais foram mais acentuados e sistemáticos na Amazônia, quando comparada ao restante do país.

A OMS (2010) considera a prevenção e o controle da hanseníase como sendo primordiais para atingir uma condição de vida humana verdadeiramente saudável em escala planetária e a inclui dentro de um grupo de 14 doenças infecciosas classificadas como "negligenciadas", pois 
"acometem desproporcionalmente as populações pobres e marginalizadas do mundo".

Mapa 1.1 - Casos de hanseníase detectados entre 1997-2006, segundo o município de residência, Brasil

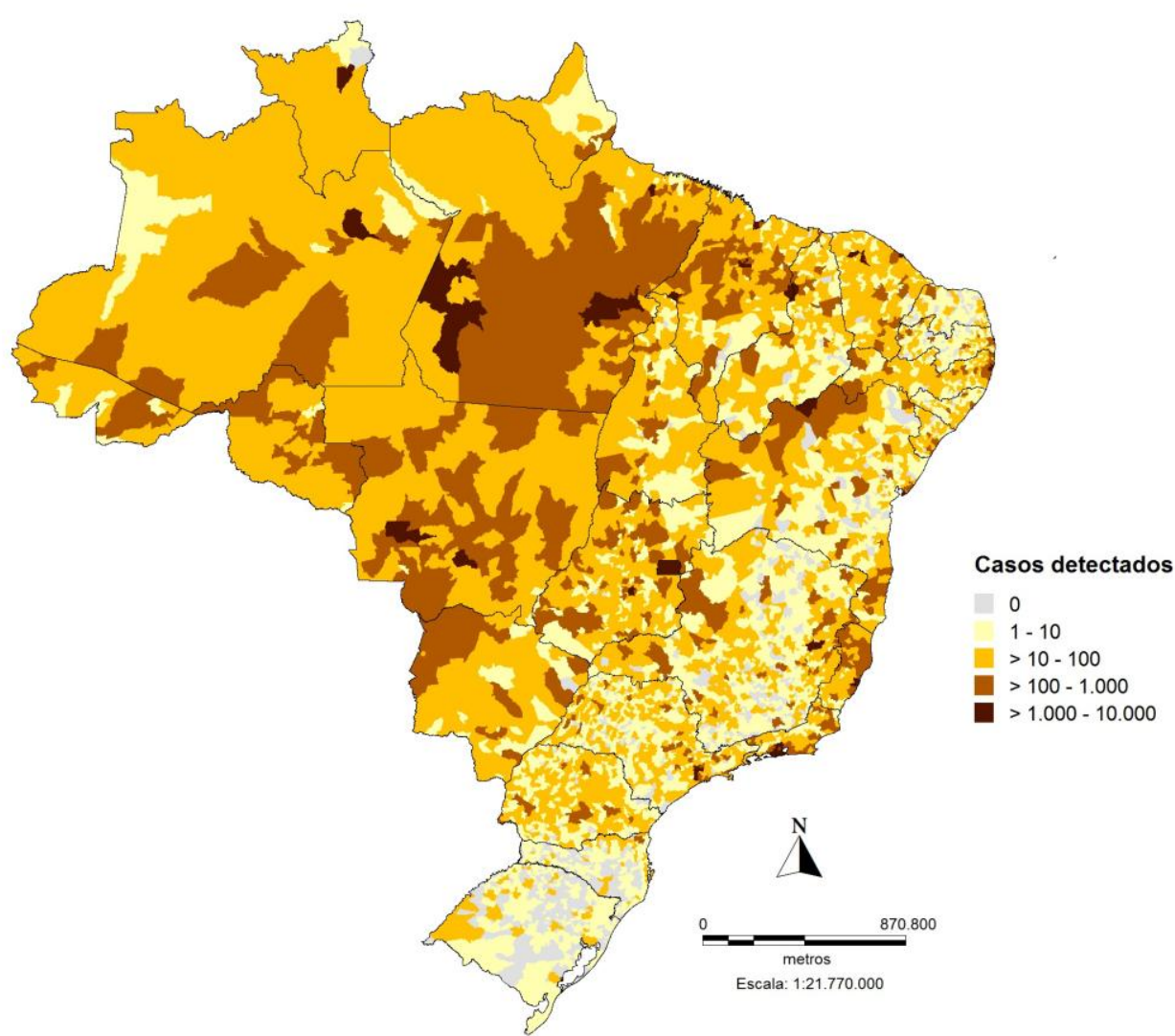

FONTE: Ministério da Saúde, Datasus, SINAN 
Mapa 1.2 - Taxa de detecção média anual de casos de hanseníase

(casos /10.000 habitantes), segundo o município de residência, Brasil - 2001-2005

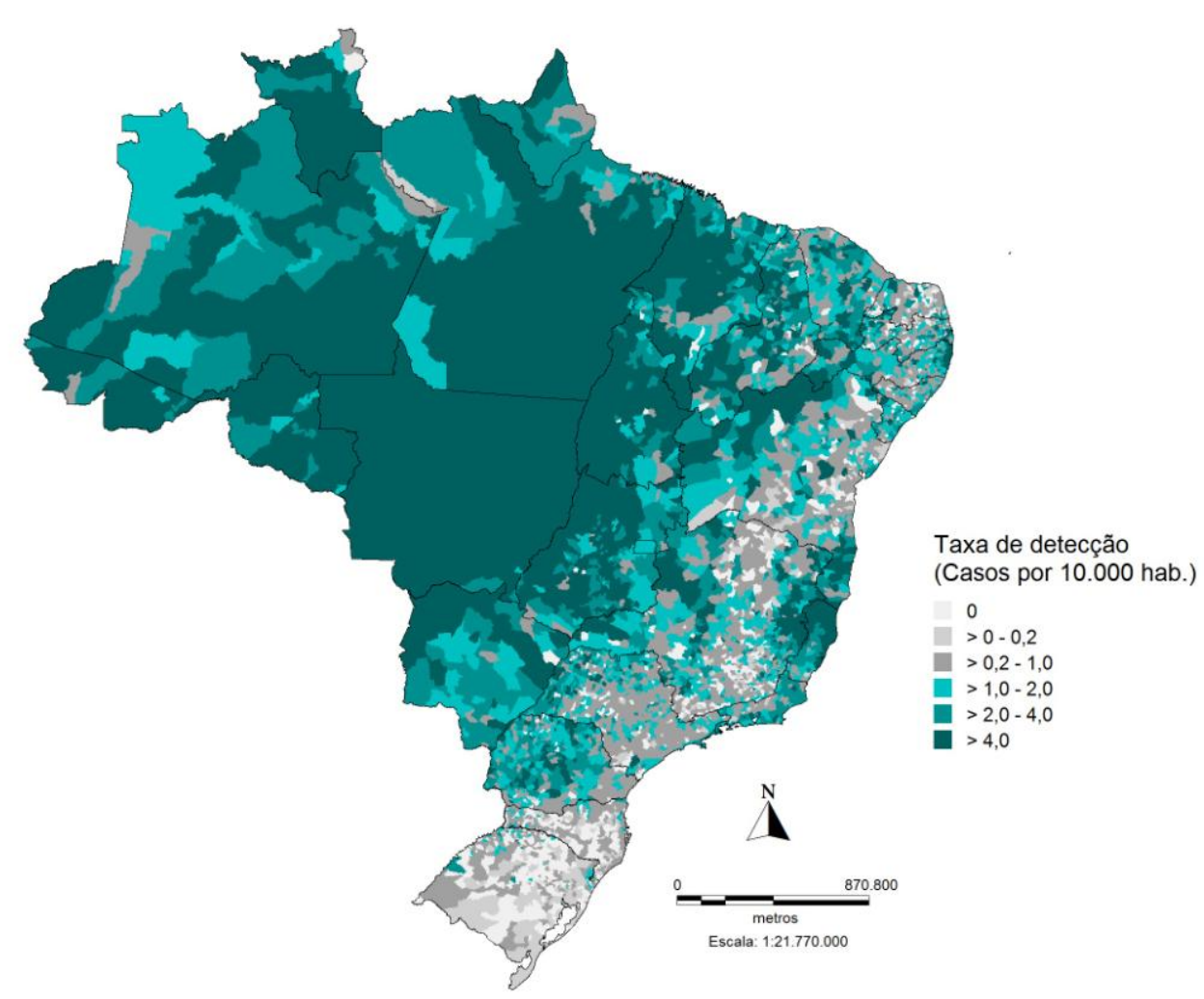

FONTE: Ministério da Saúde, Datasus, SINAN; IBGE, Estimativa populacional - 2003

Para Camargo (2008), paradoxalmente, à medida que as condições de saúde das populações subdesenvolvidas melhoram, a lista de doenças negligenciadas tende a crescer. Uma comparação dos investimentos no campo diagnóstico-terapêutico entre a hanseníase e outras doenças de importância em saúde pública, como a síndrome da imunodeficiência adquirida, poderia evidenciar um dos caminhos pelo qual a doença tornouse negligenciada. 
Outra expressão da negligência que cerca a hanseníase pode ser apreendida pelas estimativas de subnotificação de casos. Para Albuquerque et al. (1989), os indicadores da endemia devem ser analisados com cautela; preferencialmente em séries históricas, buscando evitar o risco de interpretar um resultado de baixa taxa de detecção de casos como indicativo de controle adequado sobre a doença, quando, na verdade, pode estar havendo subdiagnóstico.

O adoecimento crônico e incapacitante da hanseníase - altamente vulnerável pelo tratamento disponível atualmente, muitas vezes é tornado “invisível" pela sociedade, que estigmatiza o doente.

Falhas na reprodução da informação, desde a notificação até a divulgação dos dados, assim como dificuldades em identificar notificações múltiplas que correspondem a um mesmo indivíduo são alguns dos fatores que podem fazer com que as estatísticas sanitárias deixem de refletir o número de casos diagnosticados. Em Fortaleza, uma das maiores capitais metropolitanas do país, Façanha et al. (2006) recuperaram 411 casos atendidos nas unidades de saúde, que não constavam nas estatísticas municipais de hanseníase, o que representou $18 \%$ dos casos notificados entre 2002 e 2004.

Martelli et al. (2002), constatam com preocupação a redução do número de pesquisas em hanseníase em todo o mundo, em consequência dos escassos recursos disponíveis e observam que a avaliação da situação epidemiológica da doença, calcada estritamente na redução do indicador de 
prevalência, corre o risco de subestimar a importância da endemia. Para os autores, isto representa um perigo concreto de não se eliminar a doença, mas a pesquisa em hanseníase, sendo evidente a necessidade de investimentos na produção científica, que possa oferecer uma maior compreensão dos mecanismos de transmissão e efetividade dos métodos de prevenção e controle.

Aliada ao diminuto interesse científico-industrial no desenvolvimento de tecnologias com aplicação em hanseníase, a escassez de investimentos governamentais agrava as dificuldades do pessoal de saúde para reconhecer e lidar oportuna e adequadamente com a doença, pois interfere na provisão dos recursos diagnósticos, terapêuticos e de reabilitação física.

Penna G. et al. (2009) afirmam que os fatores que contribuem para a persistência da hanseníase na região amazônica brasileira estão em correspondência a iniquidades sociais; e, ainda, associadas a uma insuficiente descoberta de casos pelo sistema público de saúde, a imperfeições na integração dos serviços prestadores entre as esferas governamentais e a uma acelerada e desordenada urbanização de áreas metropolitanas.

O conhecimento da epidemiologia da hanseníase, particularmente com relação ao condicionamento social da endemia, pode apontar meios mais adequados de promover ambientes onde o risco da doença esteja minimizado. Estudos sobre diferenças na prevalência, detecção de casos e tendência temporal conferem as bases nas quais se estabelecem critérios 
objetivos para priorizar ações mais eficientes em programas de controle de hanseníase, direcionando a aplicação de recursos em áreas onde se prevê um maior impacto na endemia.

\section{Vigilância Epidemiológica e Controle}

Os objetivos estratégicos para reduzir a morbidade da hanseníase têm sido fundamentados nos conhecimentos epidemiológicos sobre a transmissão e evolução da doença. Estes aspectos, somados à indisponibilidade de recursos de prevenção primária para a doença, tal qual uma vacina, têm direcionado o foco do controle da doença no diagnóstico precoce do maior número de casos possível, no tratamento de todos os casos diagnosticados e na redução de danos físicos, psíquicos e sociais (Oliveira, 1990). Para o alcance destes objetivos tem sido recomendado o planejamento de ações de educação em saúde, vigilância e profilaxia de contatos, tratamento específico por meio de poliquimioterapia, prevenção de danos físicos e reabilitação (Brasil, 1989).

Em hanseníase, é destacado o papel da vigilância em saúde na medida em que reúne informações para conhecer o comportamento da doença e prever mudanças no quadro epidemiológico, possibilitando a identificação oportuna de alterações nos fatores condicionantes do processo endêmico. Os indicadores epidemiológicos comumente utilizados para 
diagnosticar a situação da endemia e para monitoramento são: coeficiente de detecção de casos - geral, por sexo e em menores de 15 anos; coeficiente de prevalência no ponto; proporção de casos diagnosticados recentemente, classificados como sendo multibacilares; e, proporção de casos com incapacidade física grau 2 ao diagnóstico. Eles ajudam a dimensionar a importância do problema da hanseníase na coletividade, sob os aspectos de magnitude e gravidade, e ainda permitem avaliar o impacto das medidas de controle na população (Ferreira, 1990).

\subsection{O Espaço em Epidemiologia e na Geografia}

O recurso de explicar a distribuição de doenças a partir das características de seu espaço de ocorrência pode ser tão antigo quanto o surgimento das primeiras civilizações. Um registro de três e meio milênios, em letras cuneiformes, conta sobre uma epidemia de peste em um ambiente prisional na Babilônia. Foram deixados tanto por Tucíades como por Hipócrates, há cerca de quatro séculos antes do início da era cristã, escritos sobre o espaço das doenças que afligiam a Grécia Antiga (Bracken, 2003).

A construção da Saúde Pública como saber, exigente do conhecimento da distribuição das doenças e seus determinantes, tem se apoiado em categorias espaciais. Exposições ambientais pela contaminação da água e do ar por agentes biológicos estiveram entre os principais 
problemas sanitários urbanos na Europa do século XIX (Gouveia, 2009). John Snow (1813 - 1858), médico britânico, analisando a epidemia de cólera de 1853 em Londres, introduziu a informação espacial aos números de ocorrência da doença e apontou o processo de transmissão da enfermidade como sendo pela água (Morabia, 2004), corroborando as teses contagionistas de disseminação de epidemias, que tiveram grande reforço pelas descobertas bacteriológicas posteriores.

O georreferenciamento, a análise temporal e o cruzamento de dados sobre o fornecimento da água e a morbidade imputada à cólera foram artifícios utilizados habilmente por Snow, que demarcaram o campo metodológico da ciência que viria a ser pronunciada como sendo a Epidemiologia. Esta jovem ciência teve seu fundamento teórico influenciado pela lógica dedutiva adotada por John Stuart Mill (1806 1873), filósofo positivista e economista inglês, um dos pensadores liberais mais influentes de seu tempo (Silva, 1985b).

Na Europa do século XIX, a noção de espaço que instrumentalizava as intervenções sanitárias acompanhou a reformulação sofrida pela concepção de causação social das epidemias, inspirada nas ideias dos defensores da Medicina Social da França e Alemanha e no movimento de reforma sanitária da Inglaterra (Barata, 1987). As propostas de intervenção passaram da organização do espaço social para a organização física do meio, traduzida, entre outras medidas, no saneamento de cidades e portos. Ao final do século XIX, firmava-se um espaço das epidemias pensado como 
sendo condicionado pelo comportamento e pelas práticas de consumo individual, longe da esfera da produção; a visão prevalente de determinação social das epidemias voltava-se aos hábitos e modos de vida da população pobre. As recomendações das autoridades de Saúde Pública londrinas para a prevenção da cólera enfatizavam o asseio corporal; e, as práticas educativas salientavam princípios higiênicos.

$\mathrm{Na}$ Saúde Pública brasileira, preocupações com o espaço das doenças estão presentes desde o seu nascedouro, quando os campos disciplinares e profissionais, que tratavam do espaço urbano e da saúde pública integravam um só objeto de intervenção, abrigado sob o "higienismo". A origem das intervenções sanitárias urbanas esteve relacionada de forma direta com o controle de epidemias (Costa, 2004). Nas epidemias de cólera e febre amarela de 1849 - 1853, quando foram dizimadas mais de 200 mil vidas, na maioria escravos e libertos pobres (Cooper, 1987), as primeiras normas para a organização do espaço urbano foram efetivamente adotadas (Marques, 1998). A economia brasileira, lastreada no comércio exterior de produtos agrícolas, era estreitamente dependente do saneamento das cidades portuárias e da saúde da sua força de trabalho.

Ao longo do século XIX e XX, a ideia de epidemia como "cadeia de eventos que tem lugar em um espaço determinado" é incorporada à racionalidade das intervenções em saúde pública. Nos moldes de intervir na rede de processos que antecede a exposição e controlar os fatores ligados à 
ocorrência de doenças, muitas medidas sanitárias alcançaram êxito em mitigar morbidez e mortalidade, tais como o fornecimento de água potável, a drenagem de esgotos, a aplicação de vacinas em massa, a suplementação de nutrientes e o controle de vetores de doenças.

O percurso histórico do uso de conceitos espaciais em epidemiologia revela íntima interface com concepções adotadas na geografia. $O$ pressuposto filosófico e metodológico, que permitiria a transformação da Geografia em uma ciência moderna, surgiu no final do século XVIII, juntamente à revolução econômica e cultural que consolidou o poder da burguesia na Europa. A ascensão intelectual da nova classe imprimiu à geografia um traço racionalista, cuja concepção de uma natureza em oposição à razão humana, que permeava o projeto positivista, acabou cingindo as demais ciências nascentes da filosofia lluminista. A necessidade de expandir e intensificar as relações comerciais estiveram subjacentes à preocupação de conhecer a superfície da terra e controlar a natureza, conformando uma geografia descritiva, objetiva e empírica (Farenzena et al., 2001).

Segundo Moraes (1991), na Alemanha do século XVIII, a coesão da estrutura feudal e a falta de um território regido por um Estado Nacional, capaz de garantir a unidade econômica e política necessária à afirmação de um comércio exterior estável, traziam a questão do espaço para a agenda da classe política germânica, desencadeando um esforço de sistematização do conhecimento geográfico por parte de estudiosos como Alexandre von 
Humboldt (1769 - 1859) e Karl Ritter (1779 - 1859), preocupados com os aspectos físico-naturais das paisagens e a relação entre o homem e o meio natural. É neste contexto que o espaço aparece de forma mais elaborada, no campo da saúde, no século XVIII, pelos estudos do alemão Ludwig L. Finke (1747 - 1837). Finke, por meio de mapas, teceu correspondências entre aspectos geográficos e as condições de saúde (Bousquat e Cohn, 2004).

A partir do século XIX, se observa com maior frequência estudos comparando taxas de mortes ou de doenças entre localidades de um mesmo nível de complexidade organizativa, como realizado por Villermé em 1826, na França; e, Chadwick em 1842 e Farr em 1852, na Inglaterra (Gouveia, 2009).

Ao final do século XIX, sob a Alemanha de Bismarck, o geógrafo Friedrich Ratzel (1844 - 1904), teve destacado papel na sistematização de uma geografia política (Sodré, 1986), tendo elaborado o conceito de "espaço vital": relação entre a população de um Estado e a utilização do seu território (Andrade, 1987). Para Ratzel, o território representa as condições de trabalho e existência de uma sociedade e a expansão do território seria essencial para a manutenção e desenvolvimento de um país, pois seria fonte de riqueza, pela exploração de recursos naturais e poder ao Estado. $\mathrm{O}$ pensamento geográfico dominante na época, ao abduzir o elemento social, igualava a natureza ao território e buscava reforço para a ideia de um espaço a ser dominado e explorado no seu potencial máximo; que seria 
privilégio de grupos sociais e políticos hegemônicos ou de alguns Estados mais poderosos no aspecto político, econômico e militar (Farenzena et al., 2001).

É notável a valorização das condições locais do meio nas propostas do alemão August Hirsch (1817 - 1894), ao apontar para um determinismo dos lugares na espacialização das doenças. Influenciado pelas ciências naturais e já vivenciando a unificação e transformação industrial do Estado alemão, Hirsch desenvolveu estudos que chamou de "Patologia Histórica e Geográfica". Seu objetivo era conhecer a distribuição, a ocorrência e os tipos de doenças em diferentes momentos do tempo e em diferentes lugares e depois relacionar estes achados com as condições externas que cercam os indivíduos, pois acreditava que estas condições circundantes determinavam o modo de vida das pessoas (Ayres, 1997).

O compromisso original da epidemiologia para com a saúde pública contribuiu para legitimar intervenções sobre o espaço das doenças. $O$ ordenamento urbano dominava as preocupações dos sanitaristas europeus ao final do século XIX; o saneamento do meio, o abastecimento de água, a pobreza e aglomeração humana estavam entre os principais condicionantes do surgimento de epidemias (Paneth et al., 2004). Mas o espectro de problemas de saúde abordados espacialmente ia além das doenças infecciosas.

A ênfase em descrever, inclusive cartograficamente, as condições materiais e sociais, estaria presente nos estudos de saúde ao longo do 
século XIX. Em plena vigência do unicausalismo da era bacteriológica, Charles Booth (1840 - 1916), inspirado nas ciências sociais, elabora mapas indicando as condições de pobreza na Londres do final do século, combinando dados individuais e censitários; vindo a tornar-se pioneiro, nos Estados Unidos, no mapeamento de saúde comunitária para doenças infecciosas e não infecciosas (Krieger, 2000).

Emile Durkheim (1858 - 1917), filósofo francês, fundou uma sociologia de métodos fortemente influenciados pelas ciências naturais; ao final do século XIX realiza uma investigação envolvendo mortalidade por suicídio, cujo tipo de delineamento de pesquisa utilizado ficaria conhecido como "estudo ecológico". Durkheim efetuou comparações geográficas entre taxas de mortalidade por suicídio de diferentes regiões da Europa e em períodos diferentes para uma mesma região; reconhecendo, já naquele momento, o contexto social como importante nível de investigação; as diferenças interpretativas entre as relações baseadas em agregados e aquelas pautadas em indivíduos; e, ainda, o viés que pode decorrer da análise de grupos (Gouveia, 2009).

Um aperfeiçoamento dos métodos investigativos logo iria direcionar a Epidemiologia para uma extensão da monocausalidade representada pelas teses multicausais, mantendo o positivismo na essência de sua lógica. Wade Hampton Frost (1880 - 1938), nos Estados Unidos, difunde que a Epidemiologia seria uma disciplina geográfica, dedicada ao estudo da doença como um fenômeno de massa e que a observação da incidência dos 
agravos deveria levar em conta múltiplos fatores, até mesmo o meio ambiente local (Frost, 1941). A maneira esboçada por Snow e proposta nas elaborações de Frost para descrever as características de uma doença de acordo com atributos da pessoa, do tempo e do lugar, acabaria por consolidar-se entre os métodos epidemiológicos; tendo Frost defendido a relevância da investigação da área de ocorrência de uma doença infecciosa no trabalho de identificação da natureza das fontes ou das rotas de transmissão (Gouveia, 2009).

Clare Oswald Stallybrass (1881 - 1951), na Inglaterra, propõe considerar os fatores que influenciam o processo de propagação de doenças infecciosas nas instâncias correspondentes ao hospedeiro, reservatório e meio ambiente (Lilienfeld, 2003); acenando para uma formulação que se tornaria muito difundida na epidemiologia, versando sobre a estrutura causal das doenças infecciosas, conhecida como "tríade ecológica" (MacMahon e Pugh, 1960).

No final do século XIX, Paul Vidal de La Blache (1845 - 1918), um dos fundadores da escola francesa de geografia, permanecendo sob o projeto positivista, questiona o paradigma determinista; ao afirmar que na própria relação homem-natureza é conformado um campo de possibilidades para a ação humana, sustentando o que chamou de "gêneros de vida". O conceito analítico de "gêneros de vida" orientou por muito tempo o pensamento geográfico do século $\mathrm{XX}$, sob a corrente "possibilista"; ela via o espaço como resultado de uma interação de influências mútuas entre uma 
sociedade localizada e um dado meio natural (Santos, 2002). As proposições de La Blache influenciaram os modelos teóricos sobre o espaço epidemiológico, reconhecidas nas abordagens ecológicas que privilegiam o lugar como unidade do estudo (Mausner e Bahn, 1974).

Na primeira metade do século $X X$, se, pela medicina, a concepção de espaço é permeada por teorias que enfatizam aspectos biológicos e individuais do processo saúde-doença, na geografia, lidera a noção de espaço como ambiente físico, restrito ao conteúdo material da paisagem e esvaziado da interferência humana (Bousquat e Cohn, 2004).

A escola sociológica americana de Chicago ajudou a introduzir um quadro conceitual mais elaborado da ecologia humana, mas dentro da orientação perpetrada por La Blache: o ambiente é a natureza primária, desprovida de história humana, onde o homem atua sobre o meio como se estivesse separado dele e não como um dos seus elementos, revelando uma dualidade homem-natureza e um apagamento da natureza socializada (Santos, 2002).

A teoria dos complexos patogênicos desenvolvida pelo geógrafo francês Maximillien Sorre (1880 - 1962), representou um significativo aporte para ampliar o potencial analítico da epidemiologia sobre a questão do espaço (Ferreira, 1991). O espaço em Sorre é continente de relações interdependentes e recursivas entre homem e natureza, que predispõem às circunstâncias que podem tornar um espaço-tempo aberto ao surgimento de doenças (Czeresnia e Ribeiro, 2000); é neste espaço-tempo que Sorre 
imagina o complexo patogênico adquirindo vida própria, do surgimento à desintegração (Lemos e Lima, 2002).

Para além de um inventário material do ambiente, o complexo patogênico pode ser descrito pela convergência de três planos onde se desenvolve a atividade humana, que Sorre denominou de habitat: o plano físico, o plano biológico e o plano social (Megale, 1984). Para Sorre, o conhecimento dos complexos patogênicos constitui a base para uma geografia médica, onde a explicação histórica completa a explicação ecológica, ajudando a evitar interpretações deterministas e reducionistas; segundo ele, o conceito de gêneros de vida de La Blache, útil para as sociedades não desenvolvidas, não mais seria aplicável no mundo moderno, onde os grupos humanos locais agem, principalmente, segundo os impulsos vindos do exterior.

No início do século XX, o alemão Alfred Hettner (1859 - 1941) estabelece outro grande movimento da geografia tradicional, que ficou conhecido como geografia racionalista, diferente do determinismo e do possibilismo, pela ênfase entregue ao raciocínio dedutivo em relação ao pensamento empírico. Mais tarde, suas ideias seriam recuperadas por Richard Hartshorne (1899 - 1992), que desenvolveu os conceitos de "integração" e "área", sendo esta considerada como um recorte investigativo da superfície terrestre cujos limites regionais são definidos durante o processo de estudo. O aprofundamento e a extensão da globalização econômica ocorridos na segunda metade do século XX, logo colocariam um 
quadro muito mais complexo às teses regionalistas que alimentavam o planejamento territorial; cujos fundamentos eram insuficientes para lidar com uma nova realidade multifacetada e em constante mudança (Moraes, 1991), desabrochada por uma forte demanda de internacionalização desigual das economias nacionais, que passaria a colocar as variáveis locais, mais afeitas à soberania dos países, em interdependência mundial.

Um posicionamento ecológico na epidemiologia, com grande intersecção com o pensamento de Sorre, surgiu com o parasitologista russo Evgeny Pavlovsky (1884 - 1965), na década de 1930. Pavlovsky formulou uma teoria sobre os nichos naturais de doenças infecciosas, propalando que mudanças introduzidas pelo homem no ambiente podem alterar a estrutura do foco de transmissão de algumas doenças que ocorrem em animais, quando elas poderiam passar a incidir também nos humanos. $O$ foco natural de uma doença subsistiria ao longo de um espaço, desde que este possa oferecer as condições ambientais mínimas para a circulação do agente infeccioso; e, se espalharia para áreas indenes como resultado do trânsito e contato decorrente da atividade humana ou por circunstâncias naturais. Sob a influência de fatores ambientais, a infectividade de determinados agentes poderia ser modificada e a epidemiologia de doenças biológica ou territorialmente restritas, adquiriria outros elementos, distribuições e contornos espaciais (Pavlovsky, s.d.).

O período que se seguiu à II Grande Guerra Mundial (1939 - 1945) assistiu ao surgimento de uma tendência pragmática em geografia, de forte 
influência anglo-saxônica, que ficou conhecida como New Geography. Esta corrente, manifestada pela valorização da geometria, da quantificação, das tecnologias e dos dados empíricos, pretendia uma linguagem matemática para a disciplina. A Nova Geografia adotava como principais instrumentos os modelos estatísticos lineares e a análise multifatorial, subordinados à teoria dos sistemas e a tese da difusão de inovações, mas sem abandonar o corte cartográfico nas análises espaciais e o ponto de vista ecológico (Santos, 2002). O enfoque quantitativo e ecossistêmico da Nova Geografia, sob a aparência de uma representação do espaço absolutamente certa, compreende o espaço como um sistema de relações entre objetos em diferentes modalidades de interação; nela, a demonstração do espaço é conduzida no plano da relação entre as partes em investigação, abstraída da totalidade e limitada a produzir um retrato reduzido a temas compartimentados de uma realidade localizada, que ofereceria significado aos resultados numéricos. Alguns geógrafos acreditavam corresponder com a Nova Geografia, a uma preocupação de rigor e eficácia nas pesquisas científicas, onde a noção de causa e efeito se impunha. A busca de analogias com as ciências exatas respondia a uma necessidade permanente de medir resultados e de obter um quadro probabilístico preciso; capaz de prospecções, simulações, previsões e ainda de descrever padrões complexos e multidimensionais em termos matemáticos, mesmo desconhecendo-se os processos de base que pudessem estar intervindo sobre o objeto em estudo. 
Na segunda metade do século XX, Morris (1957) faz menção sobre as insuficiências do unicausalismo em enfrentar os problemas de saúde pública surgidos com o crescimento das sociedades urbano-industriais. Não obstante a adoção de teses multicausais para explicar a etiologia de muitas das doenças que surgiram ou se tornaram mais frequentes neste período, as abordagens espaciais continuavam predominantemente agnósticas do ponto de vista social. A relação de distâncias, áreas e densidades assumem valores próprios nas explicações sobre o espaço na saúde das populações, interpretado mais como sendo um produto das características do lugar do que parte integrante de processos abrangentes. Nota-se um corte individual e naturalizante que predominou nas análises epidemiológicas espaciais desta fase, quando do contato com textos acadêmicos que imputam diretamente aos atributos dos habitantes e do meio, a origem de uma dada associação entre doença e espaço (MacMahon e Pugh, 1960).

Outro importante segmento do pensamento médico-geográfico, o da medicina tropical, tem suas raízes na era das grandes navegações e descobrimentos marítimos (século $\mathrm{XV}$ ao $\mathrm{XVII}$ ), principalmente pela necessidade de preservar a saúde dos colonizadores e um intercâmbio comercial estável (Costa e Teixeira, 1999). Dentro de uma visão determinista sobre o espaço da doença, a medicina tropical adotava a ideia de que algumas doenças infecciosas e parasitárias eram específicas de latitudes intertropicais, onde o clima e outros aspectos naturais do ambiente tornavam o organismo humano vulnerável a elas (Pessoa, 1978). A Geografia Médica 
do século $X X$, com suas origens na medicina tropical, é inspirada na noção de doença como resultante do desequilíbrio na relação homem-natureza. A geografia médica moderna, beneficiada pelo aprimoramento da bioestatística e das técnicas de georreferenciamento e representação por mapas, sintetiza os saberes da medicina e da geografia, para demonstrar a importância do meio geográfico no aparecimento e na distribuição das doenças. A disciplina, na fase atual, vem ganhando legitimidade ao fornecer conhecimentos à elaboração de programas de vigilância ambiental, tanto no aspecto preventivo como no controle das endemias (Lemos e Lima, 2002).

Ao término do século $X X$, a Epidemiologia encontra-se institucionalizada e com seu foco direcionado aos estudos de base individual. Este processo ocorre ao lado do refinamento dos métodos de análise de dados e da extensão do uso de recursos computacionais (Ayres, 1997), o que veio a facilitar a manipulação de grandes volumes de informações com rapidez e exatidão. Este movimento impulsionou a disseminação de estudos epidemiológicos com múltiplas variáveis, abordagens mistas espaços-temporais e em vários níveis de determinação.

Nesta fase, consolida-se uma Epidemiologia dos fatores de risco individuais, instrumentalizada pela estatística probabilística, que tem propiciado importantes avanços em clínica e em saúde pública, notadamente em doenças crônico-degenerativas e em aspectos biomédicos da saúde-doença (Gouveia, 2009). No lado da geografia, que estabelece uma leitura cada vez mais generalizada da questão do ambiente enquanto 
"crise ambiental"; o conhecimento geográfico é tornado fonte de declarações prescritivas e normativas voltadas para a resolução de problemas ambientais (Cidade, 2001), com relevante contribuição às decisões regulatórias sobre o uso do espaço e ao embasamento das atividades de controle de riscos.

Tanto a Epidemiologia quanto a Geografia, concluíram o século XX com movimentos bem definidos nos seus respectivos campos de interesse; a primeira, da abordagem populacional para a individual; e, a segunda, do foco na descrição de processos socioespaciais e do estudo da relação homem-natureza, para uma geografia eminentemente de aspirações normativas sobre o ambiente.

É reconhecido que a utilização de modelos epidemiológicos de base individual e com uma interpretação localizada do processo saúde-doença subsidiou tecnicamente intervenções que trouxeram importantes melhorias sanitárias em muitas partes do mundo. Contudo, o espaço pensado como sistema de objetos, abstraído das atividades humanas, tem sido questionado pela Geografia (Santos, 2006), assim como, na Epidemiologia, a categoria "população", concebida como agrupamentos individuais separados e independentes, tem sido objeto de críticas (Samaja, 2003).

Uma interpretação naturalizante do processo saúde-doença, que considera o espaço-tempo das doenças de modo positivo, toma corpo ao final do século XX, na metáfora da transição epidemiológica (Omran, 1971): um conjunto de suposições que buscam justificar mudanças verificadas no perfil epidemiológico de diversos países dentro de uma conjuntura que 
evolui linearmente, em etapas sucessivas. Com a emergência da aids, viria, como relata Luna (2002), a constatação de que o pretenso movimento de eliminação das doenças infecciosas indicado pela teoria da transição epidemiológica, nem sempre poderia ser verificada, e mais, que os mesmos fatores relacionados ao progresso, ao desenvolvimento socioeconômico e a modernidade, que seriam os determinantes da transição epidemiológica, também poderiam determinar processos na direção inversa, propiciando o surgimento e a disseminação de novas e velhas doenças infectoparasitárias.

Modelos teóricos para explicar a relação entre espaço e doença em populações têm sido marcados por concepções em que o espaço é visto como cenário para as representações nosológicas ou palco para a expressão de atributos biológicos, comportamentais e físicos relacionados à doença; ou ainda, como substrato aos processos de adoecimento ou fator que influencia a saúde por meio de fenômenos estritamente naturais. Neles, os conceitos sobre doenças em populações são definidos fora do espaço que os sustenta, reforçando a ideia de que a doença como fenômeno do coletivo acontece de modo isolado da formação do espaço. Recentemente, alguns autores têm usado abordagens que incluem contextos em diferentes níveis de causalidade para conceber o processo saúde-doença (Diez-Roux, 1998), como uma proposta de leitura sistemática do espaço das doenças.

Utilizando referências de Pavlovsky para explicar a evolução da doença de Chagas no estado de São Paulo, Silva (1986) examinou as 
modificações da estrutura epidemiológica da doença introduzidas pela ocupação humana do território, que se faziam contemporâneas à expansão da atividade agrícola cafeeira sobre um espaço bravio. Esta abordagem da formação do espaço endêmico traz uma noção de "espaço usado pela sociedade sob uma totalidade em movimento", a alterar conjuntamente a natureza, a funcionalidade dos lugares e as características demográficas e epidemiológicas.

Para Silva (1997), uma maneira de abrirmos uma perspectiva totalizadora à investigação epidemiológica, passa primeiramente pela identificação das relações essenciais que serviram de esteio à ocorrência da doença; e, depois, pela reconstrução do processo de organização do espaço que resultou no sistema de relações identificado. Este espaço que ele denomina de "nosológico" é o recorte da totalidade com a doença em primeiro plano, junto ao contexto que criou as condições de sua ocorrência. Neste modo de abordagem do espaço endêmico, a trajetória analítica discorre da interação sociedade-natureza aos modelos de interação humana dela gerados, fazendo o caminho inverso daquele onde se parte da doença para depois analisar como esta se insere no contexto.

Milton Santos (1926 - 2001), geógrafo brasileiro, foi inovador nas conceituações de território e lugar, escrevendo sistematicamente sobre o tema da globalização e mostrando um mundo de fronteiras essencialmente móveis, dinâmicas, multidimensionais e de relações complexas (Gonçalves, 2004). 
O espaço, na geografia de Milton Santos, é representação das condições de realização da vida sobre a terra; fator e produto de objetos e fluxos dinamizados pela sociedade e pela natureza, em relações recíprocas, a modificar unitariamente a materialidade e as relações homem-natureza. Para Santos (2006), o espaço é um referencial para a ação do homem, mas a sociedade está sempre pronta para oferecer novas funções, significados e valores ao espaço, mesmo frente a uma conjuntura pouco mutável.

Milton Santos critica as concepções que reduzem o espaço às condições físicas e naturais do meio, nas quais os agentes e as relações estão pré-determinados e adaptados a um ambiente ou a uma cultura e limitados a certas interações ecológicas de dependência estática; verdadeiras paisagens ou quadros superficiais e congelados da realidade. $O$ modo utilizado pelo autor para inquirir sobre o lugar de um fenômeno que acontece em sociedade já insere o observador no cerne do conceito de espaço; quando a espacialização é analisada sob a ótica da existência humana a transcender a realidade dada, impassível de ser medida ou prevista prescindindo de referências a uma totalidade e a uma visão de Mundo. Para Santos (2002), atualmente, as relações entre os grupos humanos e suas bases geográficas dependem muito pouco dos grupos locais e estas relações, realizadas por intermediários cuja qualidade e natureza variam em cada caso, são igualmente fontes ou elementos de reforço de estruturas sociais desiguais; fazendo das paisagens dos países subdesenvolvidos, quadros derivados das necessidades econômicas dos 
países industriais, onde finalmente se originam as decisões sobre o uso dos recursos do globo.

Czeresnia e Ribeiro (2000) criticam a fragmentação lógica incutida pelas ciências no modo de pensar o homem e o ambiente, que tem dificultado o reconhecimento do vínculo entre espaço e a distribuição de doenças e contribuído para a construção de representações que impossibilitam compreender as circunstâncias que originalmente ligam espaço e doença. Na conceituação clássica em epidemiologia, o espaço é tomado em separado do tempo e das pessoas; ele é visto como o lugar geográfico que predispõe a ocorrência de doenças e percebido como um recipiente que facilita ou não a exposição a um agente deletério. Este espaço é tido como algo que os antecede pronto e permanece independente dos seres que o habitam. Para Czeresnia e Ribeiro (2000), o espaço emerge e se diferencia dos corpos no momento da vivência concreta dos fenômenos, através de uma interface formada no processo da própria experiência; nesta concepção de espaço, a doença como fenômeno biológico e individual é contextualizada na problemática das populações em suas condições de vida e em vista do sistema de relações que as suportam.

Uma maneira que tem sido utilizada para explicar a distribuição espacial de doenças e o contexto subjacente é pela narrativa histórica sobre as condições sociais e suas consequências biológicas. A narrativa pode discorrer sobre fatores de exposição específicos, cuja ausência hipoteticamente poderia trazer desfechos diferentes; a interpretação dos 
dados é obtida a partir da análise do contexto sócio-histórico ao qual a doença ocorre (Kaufman, 2008).

A análise do processo saúde-doença pela organização do espaço permite uma apreensão de como o espaço da doença é erigido em sociedade, ao ponto de condicionar sua distribuição geográfica. Nesta abordagem, a distribuição espacial da hanseníase evidenciaria a condição de vida das comunidades afetadas e suas relações sociais e a funcionalidade dos lugares de ocorrência da doença com referência a uma totalidade, comunicando o existir social e o espaço endêmico como uma unidade que extrapola e inclui o lugar.

Para Almeida-Filho (2004), a epidemiologia encontra-se desprovida de métodos para lidar com as singularidades individuais e a amplidão dos contextos, defrontando-se atualmente com a incapacidade de operacionalizar os seus novos paradigmas que tem nos objetos totalizados e na determinação não linear algumas de suas propriedades fundamentais. Costa e Teixeira (1999) acreditam que o aspecto essencial da solução para o impasse metodológico em que se encontram as abordagens que guardam referência ao espaço social é o entendimento do processo saúde-doença enquanto totalidade.

Para Helene e Salum (2002), a endemia de hanseníase tem uma construção fortemente social, de relações profundas com o modo de vida dos grupos marginalizados da produção econômica, dos migrantes que sobrevivem nos subempregos, na periferia do sistema societário. 
Importantes contribuições ao debate sobre a determinação social da hanseníase têm sido oferecidas por outros autores, cujas conclusões foram em direção a uma extensa relação da endemia com o lugar social do doente (Tello, 1978; Parra, 1996) e com a convergência de processos demográficos em um determinado espaço (Belda, 1981).

Estudos relacionando a distribuição de doenças infecciosas a fatores socioeconômicos fazem parte dos estudos clássicos da epidemiologia. Para Chame (2006), estudos que relacionam os sistemas de populações em interação com o ambiente, este tomado de forma dinâmica, complexa e abrangente, ainda não estão consolidados na saúde pública. Este tipo de abordagem é relevante na atualidade, justamente, pelo impacto das ocupações humanas, do uso dos recursos e dos modelos produtivos e políticos na sobrevivência e na saúde, o que muitas vezes tem sido subestimado.

\subsection{Apontamentos sobre o Método Ecológico}

Conforme será descrito no capítulo correspondente, o método de delineamento epidemiológico deste estudo será o ecológico. Abordagens ecológicas são consideradas apropriadas quando o investigador deseja entender os efeitos do meio social, econômico ou ambiental na saúde. Segundo Susser (1994), medidas de atributos individuais podem não 
traduzir como os contextos afetam a saúde das pessoas e dos grupos por processos de seleção, distribuição, interação ou adaptação que provocam efeitos em direções, muitas vezes, não explicáveis por estudos de base individual. No entanto, valem alguns alertas sobre os limites do método ecológico para uma adequada interpretação dos resultados.

Em um estudo de agregados, no resultado da medida do efeito ecológico estão completamente fundidos o efeito biológico e o contextual. Adicionando a informação do nível individual é possível obter conhecimento sobre ambos, separadamente.

Estimativas de efeitos contextuais na saúde de indivíduos estão sujeitas a viés de agregação ou falácia ecológica, originária da suposição de que atributos de uma determinada área geográfica aplicam-se de forma homogênea a todos os indivíduos pertencentes à unidade grupal. Assim, em adição às fontes usuais de viés, um problema subjacente das análises ecológicas para testar efeitos biológicos é a heterogeneidade do nível de exposição e dos níveis de covariáveis dentro dos grupos. Esta heterogeneidade não é completamente capturada a partir de dados ecológicos, pois o agrupamento mistura a informação sobre a distribuição conjunta do fator de exposição, das covariáveis e da doença, redundando que associações ecológicas podem diferir da correspondente associação no nível individual. Para minimizar o viés ecológico, pode-se controlar para confundidores do nível individual e para diferenças quanto à presença de 
fatores de risco externos entre os grupos, ao ponto de tornar válida a comparação (Morgenstern, 2008).

Por outro lado, utilizando dados individuados sobre o fator de exposição, doença e covariáveis, estimativas de efeitos biológicos podem estar enviesados por variáveis contextuais como resultado da interação internivelar. Separar o efeito biológico do efeito contextual exige conhecer os dados de exposição e doença para cada indivíduo. Isto permitiria responder sobre qual a parcela do risco de contrair hanseníase que poderia ser imputada ao contexto, separadamente daquela que seria efeito do nível individual.

Viés de nível cruzado pode ocorrer em qualquer estudo onde o modelo conceitual que está sendo submetido à prova corresponde a um nível diferente daquele ao qual se referem os dados utilizados na análise para inferir conclusões (Diez-Roux, 2002). O tipo de conclusão falaciosa que o pesquisador está sujeito depende da direção da análise. De uma perspectiva individual, ela provém de efeitos de agregação de variáveis contextuais ou integrais, erros de especificação advindos da composição do grupo ou de ambos. Da perspectiva do grupo, viés de nível cruzado é fruto ou de falácia atomística, inerente a observações individuais que ignoram efeitos grupais, ou de viés de especificação, do qual a análise individual também está sujeita (Susser, 1994). Viés de agregação e erro de especificação pode se acentuar com o agrupamento. Para Hair et al. (1998), erro de especificação é a omissão de variáveis relevantes do modelo 
especificado, sendo que todos os modelos de equação estrutural sofrem de erro de especificação, na medida em que cada construto ou indicador em potencial não estiver incluído na análise.

Para Schwartz (1994), a falácia ecológica, vista como problema de validade geral, pode encorajar noções igualmente errôneas, interrelacionadas: (i) que modelos de nível individual são mais perfeitamente especificados que os de nível ecológico, (ii) que relações ecológicas são sempre substitutas de relações no nível individual; e, (iii) que variáveis do nível grupal não são causa de doença.

O controle de variáveis pode não bastar para remover o viés ecológico. Greenland e Morgenstern (1989) demonstraram que pode subsistir viés ecológico, quando é usada regressão linear simples para estimar o efeito bruto da exposição. Tomando-se como parâmetro o nível individual, o viés ecológico pode advir de viés intragrupo, que qualquer tipo de estudo está sujeito e que resulta devido ao confundimento, método de seleção ou erro de classificação. As fontes de viés ecológico próprias da análise de nível cruzado são o confundimento estabelecido pelo agrupamento, na medida em que se tenha uma taxa basal de doença em não expostos que varia entre os grupos; e, o efeito de modificação dado pelo grupo, que pode resultar se a diferença das taxas, como efeito da exposição no nível individual, varia entre os grupos.

As fontes de viés ecológico de nível cruzado podem derivar de situações onde os fatores de risco externos à análise, estão diferentemente 
distribuídos entre os grupos; ou quando a variável de exposição ecológica tem um efeito contextual no risco separado do efeito biológico de seu análogo no nível individual; ou, ainda, se o risco de adoecer depende da prevalência da doença em outros membros do grupo com os quais o indivíduo tem contato (Halloran, 2001), o que é válido para a hanseníase.

Koopman e Longini (1994) confirmam que nem todos os efeitos de fatores de risco manifestam-se diretamente sobre indivíduos, tal como pode ocorrer em doenças infecciosas, quando comumente o risco é manifestado durante o contato, tornando uma dada exposição dependente de consequências de exposições que ocorreram em outros indivíduos; o que perturba a segurança de admitir independência das taxas de doença entre grupos. Coeficientes de regressão linear de estudos ecológicos, assim como diferenças de risco de estudos de base individual podem não refletir quanto de mudança nos níveis de doença pode ser esperado de uma dada alteração no nível de exposição, quando processos populacionais não lineares são gerados por esta relação de dependência.

Autocorrelação constituiu um desafio metodológico corrente nos estudos ecológicos (Dufault e Klar, 2011), tanto a de caráter espacial como temporal. Elliott e Wakefield (2001) afirmam que, se todas as características podem ser medidas, em tese, elas poderiam estar apropriadamente descritas para uma análise estatística, assim como um modelo com múltiplas variáveis poderia ser completamente especificado; mas, na prática, isto não acontece e fatores não medidos podem introduzir dependência espacial. 
Estimativas de risco de áreas tenderão a estar relacionadas, uma vez que os eventos que ocorrem nas unidades espaciais não são independentes, incluindo aqueles do ambiente físico e social.

$\mathrm{Na}$ análise ecológica, certos preditores podem apresentar colinearidade, especialmente fatores sociodemográficos e ambientais (Morgenstern, 2008), tendendo a estarem mais relacionados estatisticamente um com o outro do que no nível individual, sendo difícil, muitas vezes, separar estatisticamente os efeitos destas variáveis.

\subsection{Hipóteses e justificativa}

Segundo a OMS (1992), o estudo da saúde ambiental não se limita aos efeitos patológicos acarretados por agentes químicos, físicos e biológicos; ele deve abarcar, de forma concomitante, a observação da qualidade de vida da população no que se refere ao ambiente físico, ao bem-estar mental e às condições sociais de uma forma mais ampla.

O modelo de desenvolvimento socioeconômico, que pressupõe um determinado uso do território, mantém íntima relação com a carga de morbidade da população. Embora a economia e a demografia se destaquem como sendo pontos óbvios de interação entre as sociedades e o meio ambiente; e, ainda, com toda a ampliação dos conhecimentos e do âmbito da biologia, há muito que esclarecer sobre os diferentes impactos de 
processos sociodemográficos na saúde humana. Avolumam-se registros neste sentido e isto aumenta a necessidade de saber como processos de saúde-doença são influenciados por diferentes contextos e chegam a atingir determinada espacialização (Pacheco-Ferreira et al., 2005). Muitos esquemas de interpretação epidemiológica que não tem levado em conta os condicionantes sociais acabaram endossando respostas ineficazes aos problemas de saúde pública (Nossa, 2008).

A hanseníase tem sido relacionada às condições de vida. O nível de escolaridade e de renda, o acesso a recursos sanitário-assistenciais, as migrações e a salubridade das moradias comparecem como fatores que supostamente poderiam contribuir para delimitar espaços endêmicos da doença (Rodrigues-Júnior et al., 2008; Imbiriba et al., 2009; Soares dos Santos et al., 2010).

Navarro et al. (2006) consideram as condições de saneamento, aglomeração e circulação de pessoas como potenciais favorecedores da transmissão da hanseníase. $\mathrm{Na}$ perspectiva dos autores, movimentos migratórios podem fazer parte de um mesmo processo de intervenção ambiental, com efeitos danosos sobre a saúde.

Um comportamento epidemiológico focal da hanseníase tem sido descrito, com aglomerados de casos em lugares onde têm ocorrido intensos fluxos migratórios, como observado ao longo de estradas federais abertas recentemente, que cruzam estados amazônicos e em áreas de expansão agrícola do Mato Grosso, Pará, Rondônia e Tocantins (Magalhães e Rojas, 
2007); e, na faixa de fronteira internacional dos estados do Norte e CentroOeste do Brasil (Peiter, 2007). Penna et al. (2009), encontraram 29 conglomerados estatísticos de casos, abrangendo 789 municípios, estimando que $20 \%$ da população brasileira estão sob condições de alta endemicidade.

O contexto sociodemográfico muitas vezes, não se deixa explicar apenas por fatores locais, sendo necessário conceber o espaço para além de unidades isoladas, em uma rede geográfica, no marco da qual, impulsos externos e internos encontram uma resposta localizada, que também pode corresponder a um perfil epidemiológico próprio, mas integrado.

Ao tempo em que se estende e se aprofunda a modernização do território e são esgotados os recursos naturais; situação muitas vezes delineada por vetores políticos e econômicos de origens distantes de seus espaços de convergência e alheios aos interesses locais, a modernização assume um caráter conflituoso e inclinada a atingir espaços novos; uma vez que estes são mais permeáveis às inovações tecnológicas, pois costumam oferecer menor resistência decorrente de normas e formas instaladas anteriormente sobre o território e pelo encontro de uma natureza que pode ainda estar plena de recursos.

A hiperendemicidade da hanseníase constatada atualmente na área de fronteira agrícola, que em contiguidade abrange vários estados das regiões Centro-Oeste, Norte e Nordeste do Brasil, faz supor alguma relação do processo endêmico da hanseníase com a ocupação de lugares novos; de 
onde a movimentação demográfica necessária para o desbravamento de um campo virgem de mecanizações parece fomentar a incidência da doença.

A hipótese que lidera a elaboração desta pesquisa é que a delimitação de espaços endêmicos de hanseníase surge como processo sincrônico e subordinado à formação do território. Com esta tese, o modelo de risco assumido para explicar a distribuição da hanseníase é construído com ênfase não nos meios de transmissão, mas nos fatores sociodemográficos próprios do contexto, que poderiam qualificar a exposição ao $M$. leprae.

O condicionamento da endemia de hanseníase pode ser explorado no nível das relações sociais, econômicas e de poder. Nesta abordagem o foco analítico é o papel exercido pela coletividade na saúde dos indivíduos, enquanto grupos com diferentes vulnerabilidades e é assumida a determinação biocultural do adoecimento, sua complexidade e variabilidade sociodemográfica. Na busca de um modelo que possa clarear a relação entre hanseníase e formação do espaço, o contexto é pensado como sendo de conteúdo híbrido - social e natural. Para Godelier (2001), existe no ser social do homem mais do que a soma de suas necessidades individuais ou sociais, há a manifestação de necessidades não pessoais, ligadas à natureza das relações que estabelece com outros homens. Estas necessidades ressurgem ao serem reproduzidas as relações sociais, pois carregam o conjunto ou a parte essencial que constitui a base da sociedade, 
Ihes imprimindo certa lógica global, que simultaneamente identifica indivíduos e grupos.

Considerando que a maior parte das relações sociais é produzida pela instituição de laços de pessoa a pessoa; e, tendo que o $M$. leprae é inerte, desprovido de mobilidade ativa, adaptado ao reservatório humano e de vida intracelular obrigatória; o que o coloca em movimento e o faz "circular em um sentido e depois outro" é interferido por relações sociais. Segundo Godelier (2001), a natureza do objeto que é transferido no contato entre as pessoas não é indiferente ou insignificante, mas imediatamente comunicador do contexto onde eles acontecem, mesmo sendo o objeto desconhecido para seus atores ou partilhado involuntariamente.

A diversidade histórica e geográfica dos lugares os faz responder às mudanças de forma desigual, o que produz diferentes resultados socioespaciais por referência a uma mesma totalidade (Santos, 2008). A sociedade, incorporada ao espaço, hoje principalmente pelo trabalho e pela técnica, recria conteúdos materiais e imateriais para um mesmo espaço a cada necessidade, unificando e fazendo surgir frações de espaço (Cândido, 2001), assim como diferentes distribuições da hanseníase. Espaço é entendido aqui como sendo a expressão das experiências passadas dos indivíduos e da sociedade, corporificadas em formas sociais em movimento, onde o tempo da natureza e o tempo técnico seriam inscritos e reinscritos, mesmo sem ter o que foram antes, totalmente apagados (Santos, 2006). 
Contrastes epidemiológicos em hanseníase e na história da formação do território direcionaram a escolha da área a ser estudada para dois estados brasileiros, contíguos e nascentes de uma mesma grande unidade territorial, são eles: Mato Grosso (MT) e Mato Grosso do Sul (MS). 

2. Objetivos 



\section{OBJETIVOS}

Esta pesquisa tem por objetivo investigar quais fatores sociodemográficos poderiam ter influenciado a distribuição da hanseníase na população dos municípios dos estados do Mato Grosso e Mato Grosso do Sul, no período de 2000 a 2006 e gerar hipóteses sobre o condicionamento social da endemia. Para atingir estes objetivos é pretendido:

- descrever variações epidemiológicas e geográficas da doença;

- analisar a situação epidemiológica frente às condições sociodemográficas;

- analisar a associação da taxa de detecção de hanseníase a fatores sociodemográficos, enquanto variáveis ecológicas que poderiam explicar a variabilidade das taxas de detecção entre os municípios;

- formular hipóteses sobre o processo de transmissão da doença no nível populacional; e,

- introduzir a produção da endemia de hanseníase na perspectiva da formação do território. 

3. Métodos 



\section{Métodos}

Um estudo epidemiológico transversal com desenho ecológico de grupos múltiplos foi delineado para estimar o efeito ecológico de fatores sociodemográficos sobre as taxas de detecção de hanseníase. A variável dependente foi representada pela taxa de detecção anual de hanseníase e medida enquanto a média entre os anos de 2000 a 2006.

A unidade de análise escolhida foi o município e o universo em estudo constituído por um conjunto de 203 municípios, sendo 126 do Mato Grosso e 77 do Mato Grosso do Sul. Tomando por referência o Censo demográfico 2000 (IBGE, 2008) a população dos municípios somou 4.582.354 habitantes, sendo 2.504.353 do MT e 2.078.001 do MS. Os municípios de Figueirão, no MS; e, Itanhangá e Ipiranga do Norte, no MT, instalados em 2005, não foram incluídos no estudo.

A escolha da abordagem ecológica para investigar a associação da taxa de detecção de hanseníase com fatores sociodemográficos partiu dos pressupostos de que: (1) a variação dos fatores de risco poderia ser maior entre grupos populacionais do que entre indivíduos; (2) fatores sociodemográficos exerceriam efeitos contextuais importantes sobre o risco;

(3) o risco de contrair hanseníase depende do risco em outras pessoas com as quais se tem contato; e, (4) a proteção contra a infecção pelo $M$. leprae pode assumir características de imunidade de grupo. 
Foi presumido para a área em estudo que o município seria o território onde são ordenados, espacialmente, os fatores sociodemográficos do contexto local, que poderiam influenciar a conformação das taxas de detecção de hanseníase. Esta assunção fez recair sobre os limites municipais a escolha da unidade de análise.

Este estudo foi aprovado pelo Comitê de Ética em Pesquisa da Faculdade de Medicina da Universidade de São Paulo, em sessão de 29 de setembro de 2010, sob o protocolo 290/10.

\subsection{Variável dependente}

Com o objetivo de verificar o quanto de doença tinha sido detectado, em um período de tempo, em relação ao tamanho da população, definiu-se que a variável dependente seria a taxa de detecção média anual de hanseníase. Esta taxa foi calculada segundo os casos de hanseníase diagnosticados recentemente, registrados no Sistema de Informação Nacional sobre Agravos de Notificação - Sinan, do Ministério da Saúde. A fonte das informações epidemiológicas foi o Departamento de Informática do Sistema Único de Saúde (Datasus), Ministério da Saúde (Brasil, 2008b).

O Sinan foi desenvolvido no início da década de 1990, tendo como objetivo a coleta e processamento dos dados sobre agravos de notificação obrigatória de abrangência nacional, fornecendo informações para análise da morbidade e estimação da magnitude dos problemas sanitários sob vigilância (Laguardia et al., 2004). 
É preconizado nacionalmente pelo Ministério da Saúde do Brasil, que após a confirmação do diagnóstico de hanseníase, o caso seja notificado à autoridade sanitária local, quando alguns dados clínico-epidemiológicos são registrados individualmente em ficha padronizada. Esta ficha serve de instrumento de coleta primário de dados para alimentar o sistema de informação epidemiológica, no nível hierárquico mais descentralizado do sistema de vigilância (Brasil, 2007). A investigação e notificação de casos de hanseníase são obrigatórias em todo território nacional (Brasil, 2010).

Uma rotina de críticas sobre a base de dados do Sinan, com relação à duplicidade e consistência, antecede a divulgação pelo Datasus dos dados epidemiológicos. A completude dos campos referentes às variáveis utilizadas mostrou-se suficiente para os objetivos da pesquisa (Brasil, 2008c).

A variável dependente taxa de detecção anual representa o número de casos de hanseníase diagnosticados recentemente (código A30 da Classificação Internacional de Doenças - CID10 - OMS, 1994) na população residente. O Ministério da Saúde, para orientar as ações de vigilância epidemiológica e controle em todo o país (Brasil, 2005), adota a definição da OMS para "caso de hanseníase", quando estão presentes pelo menos um dos dois conjuntos completos de critérios: (1) lesões de pele com alteração de sensibilidade; (2) espessamento de nervo periférico acompanhado de alteração de sensibilidade ou baciloscopia positiva para M. leprae.

É de se esperar que municípios com pequena população experimentem uma larga variação da taxa de detecção anual. Para conferir 
maior estabilidade à variável, optou-se por considerar o montante de casos detectados durante a série contínua de 2000 a 2006. Verificou-se dentro da série histórica divulgada que a partir do ano 2000 a frequência de casos diagnosticados nos respectivos anos adquire certa estabilidade, o que supõe a base de dados ter atingido maior consistência naquele momento.

O cálculo da taxa de detecção média anual foi realizado pela soma dos casos de hanseníase diagnosticados a cada ano na população residente em município da área em estudo, notificados entre 2000 e 2006. Em seguida foi procedida a divisão deste montante por sete anos, correspondendo ao tamanho do período considerado; e, depois, foi procedida a divisão deste resultado pela população, em número de habitantes. A população utilizada para calcular a taxa de detecção média para o período foi a do ano de 2003, ponto médio do intervalo 2000 - 2006 (Instituto Brasileiro de Geografia e Estatística - IBGE, 2007). As taxas de detecção municipais foram ajustadas por idade pelo método de padronização direta (Laurenti et al., 1985); tendo, como padrão de comparação, a distribuição etária da população brasileira do ano 2000, entre menores de 15 anos e 15 anos e mais (IBGE, 2008). O resultado foi expresso em casos detectados por ano e a base de cálculo utilizada foi a de 10 mil habitantes. 


\subsection{Indicadores sociodemográficos}

Para representar o contexto sociodemográfico dos municípios, um amplo conjunto de indicadores foi inicialmente listado para a seleção das variáveis independentes. Baseado na publicação da Rede Interagencial de Informação para a Saúde - RIPSA (2008) foram arrolados 62 indicadores, classificados nas seguintes dimensões:

a) Dimensão demográfica $(n=16)$ : Taxa de crescimento médio geométrico anual da população 1991/2000; Proporção da população em situação urbana de domicílio; Taxa de fecundidade total; Taxa de natalidade; Razão de sexos; Razão de dependência; Proporção de idosos; Idade mediana da população; Índice de sobremortalidade masculina; Tamanho populacional; Densidade demográfica; Média de pessoas por família; Proporção da população segundo o deslocamento para trabalho ou estudo; Proporção da população não natural da Unidade Federada (UF); Proporção da população não natural, migrante de outra UF nos últimos cinco anos; Proporção da população não natural, migrante de outra UF nos últimos 10 anos.

b) Dimensão socioeconômica ( $n=14)$ : Índice de Desenvolvimento Humano Municipal (IDHM); Razão de Renda; Produto Interno Bruto (PIB) per capita; Índice de desmatamento per capita; Rendimento nominal familiar médio mensal; Proporção de famílias com renda per capita abaixo de 1/4 de salário mínimo; Proporção de famílias sem rendimento; Proporção da população moradora em domicílios com chefes de família com rendimento abaixo de um salário mínimo; Proporção da população economicamente ativa (PEA); 
Taxa de desemprego (PEA não ocupada); Proporção da PEA ocupada sem vínculo formal de trabalho; Proporção da população economicamente ativa ocupada no setor primário; Razão da proporção de pessoas do sexo feminino chefes de famílias com rendimento abaixo de um salário mínimo sobre a de chefes de família do sexo masculino na mesma situação; Índice do número de empregos por habitante.

c) Dimensão educacional $(n=5)$ : Proporção da população acima de 14 anos de idade sem instrução; Proporção da população de 20 a 50 anos de idade com menos de oito anos de estudo; Proporção de domicílios com chefes de família com menos de quatro anos de estudo; Razão da proporção de pessoas do sexo feminino chefes de famílias alfabetizadas sobre a de pessoas do sexo masculino na mesma situação; Proporção da população com mais de 10 anos de idade sem instrução ou com menos de quatro anos de estudo.

d) Dimensão habitacional e de saneamento $(n=8)$ : Proporção da população moradora em domicílios com seis ou mais pessoas; Proporção da população moradora em domicílios com média de mais de duas pessoas por cômodo; Proporção da população moradora em domicílios com média de mais de três pessoas por dormitório; Proporção da população moradora em domicílios com múltiplas famílias; Proporção da população moradora em domicílios sem banheiro; Cobertura de domicílios com abastecimento público de água tratada; Cobertura de domicílios com coleta pública de lixo; Cobertura de domicílios ligados à rede pública de esgoto sanitário ou fossa séptica. 
e) Dimensão sanitário-assistencial ( $n=19)$ : Taxa de mortalidade infantil; Taxa de mortalidade em menores de cinco anos; Taxa de mortalidade específica por doenças transmissíveis; Proporção de nascidos vivos de baixo peso; Índice de profissionais de saúde por mil habitantes; Índice de estabelecimentos de saúde por mil habitantes; Gasto público com saúde per capita; Gasto público com saúde como proporção do PIB municipal; Recurso médio anual investido em Atenção Básica por habitante; Média de consultas médicas do Sistema Único de Saúde (SUS) por habitante/ano; Média anual de consultas médicas do SUS nas especialidades básicas por habitante; Índice de Unidades Básicas de Saúde por mil habitantes; Índice de Unidades Especializadas por mil habitantes; Índice de Unidades de Vigilância Epidemiológica por mil habitantes; Proporção da população coberta pela estratégia de Atenção Saúde da Família; Proporção de óbitos sem assistência médica; Proporção de óbitos por causas mal definidas; Índice de notificação anual de agravos por mil habitantes; Produção do SUS de baciloscopias de raspado intradérmico para pesquisa de $M$. leprae por mil habitantes.

\subsection{Variáveis independentes}

Para a seleção das variáveis independentes foram contempladas todas as dimensões do contexto sociodemográfico propostos na publicação da RIPSA (2008), procurando-se evitar a inclusão de mais de um indicador medindo o mesmo aspecto de uma determinada dimensão. O processo de 
seleção foi dirigido pela escolha de indicadores supostamente com menos limitações dentro de uma mesma dimensão; as limitações levadas em conta no processo de seleção estão delineadas no documento da RIPSA (2008). Após verificar a disponibilidade de cada variável e de fonte secundária de informação com dados desagregados no nível municipal, finalizou-se com um número de 14 variáveis, descritas a seguir.

\section{Tamanho populacional}

Relaciona-se ao quantitativo territorial da população em um corte do tempo. É resultado da interação dos vetores demográficos que modificam seu estado: mortalidade, natalidade e movimentos espaciais da população (Sauvy, 1979). A fonte utilizada foi o Censo Demográfico 2000 (IBGE, 2008).

\section{Taxa de crescimento populacional médio geométrico anual 1991/2000}

Revela em que proporção o tamanho de uma população aumenta a cada ano, em média, em relação ao ano anterior, em um período intercensitário. Ele está sujeito a fenômenos de nascimentos, mortes e migrações. A fonte utilizada foi o Censo Demográfico 2000 (IBGE, 2008).

\section{Proporção da população em situação urbana de domicílio}

Indica a fração da população residente no meio urbano. As variáveis utilizadas são: número de pessoas que residem em domicílios particulares permanentes em situação urbana; e população residente. No cálculo, o número de residentes em situação urbana de domicílio foi dividido pela 
população geral. A fonte utilizada foi o Censo Demográfico 2000 (IBGE, 2008). Segundo a metodologia utilizada no Censo 2000 (IBGE, 2003), foi considerado "domicílio urbano" aquele situado na área interna ao perímetro urbano de uma cidade ou vila, sendo este perímetro definido por lei municipal; e, rural, aquele situado fora desta marcação. Para municípios onde não existia legislação regulamentadora sobre a matéria, foi orientado estabelecer um perímetro urbano para fins da coleta censitária, cujos limites deveriam ser aprovados pelo prefeito local. Baseando-se na Lei Federal 9785/99 (Brasil, 1999), a definição do perímetro urbano pelos gestores municipais deveria estar condicionada à instalação de infraestrutura básica composta, minimamente, por equipamentos públicos para escoamento das águas pluviais, iluminação pública, redes de esgoto sanitário e abastecimento de água potável, e de energia elétrica pública e domiciliar; e, vias de circulação, pavimentadas ou não. Frente à metodologia adotada pelo Censo Demográfico 2000, é suposto que a situação do domicílio indique, entre outros aspectos, diferentes condições de saneamento do meio.

\section{Produto Interno Bruto (PIB) per capita}

É o valor médio agregado por indivíduo, em moeda corrente e a preços de mercado dos bens e serviços finais produzidos ao ano em determinado espaço geográfico. O cálculo do PIB dos municípios baseia-se na distribuição entre eles do valor adicionado das atividades econômicas obtidas pelas contas regionais do Brasil. O valor per capta é calculado pela divisão do PIB pela população do município. Utilizou-se o ano 2000 como 
referência para o valor do PIB municipal, cuja fonte foi o IBGE - Sistema de Contas Nacionais (IBGE, 2009) e o denominador populacional obtido do Censo 2000 (IBGE, 2008).

\section{Rendimento nominal familiar médio mensal}

Expressa o padrão médio de rendimentos obtido em um mês pelas famílias residentes em uma determinada área geográfica em um determinado corte do tempo. Dimensiona o nível de renda médio da população, contribuindo para a análise da situação socioeconômica ao possibilitar a identificação de contrastes regionais de renda média. O método de cálculo envolve a soma dos rendimentos de todas as famílias dividida pelo número de famílias do lugar. A fonte dos dados foi o Censo Demográfico 2000 (IBGE, 2008) e a informação sobre renda está baseada no "mês de referência" adotado na pesquisa declaratória censitária.

\section{Proporção da população moradora em domicílios com seis ou mais pessoas}

Refere-se à proporção da população que habita domicílios particulares permanentes com seis ou mais pessoas, independente do tamanho, número ou tipo de cômodos constituintes da moradia. É um indicador habitacional relacionado às condições de ocupação do domicílio, que pode estar ligado a fatores culturais e socioeconômicos. As variáveis utilizadas são: número de pessoas que residem em domicílios particulares 
permanentes com mais de seis moradores e população residente. A fonte utilizada foi o Censo demográfico 2000 (IBGE, 2008).

\section{Taxa de desemprego (PEA não ocupada)}

Indica quanto representa, proporcionalmente em relação à população residente, a população com 10 anos ou mais de idade, economicamente ativa, não ocupada no trabalho principal. Define-se como população economicamente ativa (PEA) o contingente de pessoas de 10 e mais anos de idade que está trabalhando ou procurando trabalho. Foram classificadas como desocupadas na semana de referência as pessoas sem trabalho nessa semana que tomaram alguma providência efetiva na procura de trabalho no período de referência de 30 dias (IBGE, 2008). Este indicador mede o grau de insucesso dos indivíduos que desejam trabalhar e não conseguem encontrar uma ocupação no mercado de trabalho (desemprego aberto). A fonte foi o Censo Demográfico do ano 2000 (IBGE, 2008).

\section{Proporção da população com mais de 10 anos de idade sem instrução ou com menos de quatro anos de estudo}

Este indicador dimensiona o acesso aos recursos de escolarização. $O$ nível de instrução inferior a quatro anos de estudo tem sido utilizado como proxy do analfabetismo funcional (RIPSA, 2008). Para o cálculo do indicador procede-se a divisão da população residente com 10 anos ou mais de idade sem instrução ou com menos de quatro anos de estudo pela população 
residente. A fonte dos dados sobre instrução e os dados populacionais foi o Censo Demográfico do ano 2000 (IBGE, 2008).

\section{Proporção da população moradora em domicílios com média de mais de três pessoas por dormitório}

Aponta a parcela da população em condições habitacionais consideradas insatisfatórias. Mede indiretamente um aspecto qualitativo da moradia, utilizando o critério do grau de aglomeração humana no dormitório (Genovois, 2001). Um dos critérios adotados no Censo Demográfico 2000 (IBGE, 2008) para considerar um domicílio como "adequado" foi ocupação de até dois moradores por dormitório. A densidade de moradores por dormitório é resultante da divisão do total de moradores pelo número de dormitórios do domicílio particular permanente; a proporção da população, moradora em domicílios com mais de três pessoas por dormitório é obtida da divisão do total de moradores em domicílios com mais de três pessoas por dormitório pela população residente. A fonte utilizada foi o Censo Demográfico do ano 2000 (IBGE, 2008).

\section{Proporção da população moradora em domicílios sem banheiro}

Indica a proporção da população que não tem acesso a habitação provida de um recurso básico de higiene. Este indicador é calculado pela divisão do total de moradores em domicílios sem banheiro pela população residente. A fonte utilizada foi o Censo Demográfico 2000 (IBGE, 2008), onde foi considerado como banheiro o cômodo do domicílio que dispõe de 
chuveiro ou banheira e aparelho sanitário, e era de uso exclusivo dos moradores do domicílio (IBGE, 2008).

\section{Proporção da população não natural da Unidade Federada (UF)}

Refere-se à proporção da população residente cujo lugar de nascimento não pertence à mesma unidade da federação. As variáveis utilizadas são: número de pessoas não naturais da unidade da federação de residência; e, população residente. Dimensiona um aspecto da estrutura demográfica relacionada ao último deslocamento populacional definitivo entre lugares do país, por referência à naturalidade, estabelecendo a proporção de imigrantes em uma determinada população e secção temporal (Sauvy, 1979). A fonte utilizada foi o Censo Demográfico 2000 (IBGE, 2008).

\section{Proporção da população não natural migrante de outra UF nos últimos} 10 anos

Quantifica a contribuição das migrações recentes no movimento geral da população frente ao peso das forças de natalidade e mortalidade, apontando qual a parcela demográfica não natural, frente à população residente, que teve seu derradeiro deslocamento definitivo, interno ao país, ocorrido no último decênio. A fonte utilizada foi o Censo Demográfico 2000 (IBGE, 2008). 


\section{Proporção da população coberta pela estratégia de Atenção Saúde da}

\section{Família}

Esta informação refere-se à população potencialmente assistida nas Estratégias de Agentes Comunitários de Saúde e de Saúde da Família. Para o cálculo da cobertura, leva-se em conta o número de agentes e de equipes cadastradas pelos estabelecimentos de saúde e as respectivas capacidades operacionais. A fonte utilizada foi o Ministério da Saúde, Datasus, Sistema de Informação da Atenção Básica - SIAB (Brasil, 2009a); o indicador corresponde à média anual do período de 2000 a 2006, considerando o número de equipes cadastradas no mês de dezembro de cada ano.

\section{Média anual de consultas médicas do Sistema Único de Saúde - SUS nas especialidades básicas por habitante}

Relaciona o número de consultas médicas básicas (pediatria, ginecoobstetrícia e clínica geral) produzidas ao ano no SUS, com a população do local do estabelecimento. Não inclui as consultas básicas realizadas em estabelecimentos sem vínculo com o SUS. São consideradas as consultas destinadas a pessoas não residentes, embora seja utilizada, como denominador de cálculo, a população geral. A fonte utilizada foi o Ministério da Saúde, Datasus, Sistema de Informação Ambulatorial - SIA (Brasil, 2009a); a média anual se refere ao período de 2000 a 2006. 


\subsection{Plano de análise dos dados}

\section{Estatística descritiva}

A distribuição dos casos de hanseníase diagnosticados recentemente foi descrita em valores brutos, de forma geral, por faixa etária, sexo, avaliação de incapacidade física e classe operacional da forma clínica; pela razão de frequências entre as formas clínicas operacionais (paucibacilar e multibacilar); taxas de detecção de hanseníase por faixa etária e sexo; e, razão das taxas de detecção entre as faixas etárias e sexos.

A caracterização sociodemográfica foi baseada nas 14 variáveis independentes e representada em tabelas de frequência com seus valores ordenados entre os dois estados. Em vista da ocorrência de valores discrepantes nos municípios, foi considerada a utilização da mediana e da amplitude interquartílica como medidas de tendência central e de dispersão para sumarizar os conjuntos de dados (Zanetta, 2004).

Uma matriz de dados dos municípios foi construída com os valores da variável dependente e das variáveis independentes. Para os cálculos estatísticos foi utilizado o pacote estatístico Stata 10 (StataCorp, 2007).

\section{Estatística analítica}

Com o objetivo de selecionar as variáveis independentes que melhor pudessem representar o contexto sociodemográfico, foi primeiramente utilizada uma técnica de regressão linear simples. Para cada relação simples 
entre a variável dependente e uma independente, foi verificada a força da associação estatística entre elas. As variáveis independentes foram selecionadas a partir do critério de apresentarem significância estatística do resultado da inclinação da reta de regressão linear com valor de $p<0,2$ (Hosmer e Lemeshow, 2002).

As variáveis selecionadas foram em uma próxima etapa submetidas a um procedimento estatístico de regressão linear múltipla, visando obter um modelo explicativo singular da variação da taxa de detecção de hanseníase, por meio do ajuste simultâneo destas variáveis. Este modelo deveria representar a melhor estimativa dos parâmetros da função matemática que poderia explicar a associação entre taxa de detecção de hanseníase e fatores sociodemográficos com simplicidade e acurácia (Greenland, 2008). Isto significa que o modelo final deveria conter o menor número possível de variáveis independentes, perdendo o mínimo de precisão e poder explicativo.

A relação entre status de saúde e condições socioeconômicas tem sido amplamente explorada na literatura científica, mas o desembarace de variáveis fortemente relacionadas representa um considerável desafio tanto na coleta como na análise dos dados (Fine, 1981), constituindo-se o controle simultâneo de variáveis uma saída metodológica.

A seleção das variáveis que foram incluídas na função de regressão obedeceu à estratégia step down regression (Kirkwood, 1988). Na modelagem, inicialmente, todas as variáveis foram incluídas simultaneamente na função de regressão e registrado o coeficiente de 
determinação múltipla; depois foi retirada uma variável de cada vez e registrado o coeficiente correspondente ao modelo resultante. A variável que apresentava a menor contribuição no poder explicativo do modelo era subtraída do conjunto e assim sucessivamente. O processo continuou até que cada uma das variáveis remanescentes apresentasse um coeficiente de regressão parcial com probabilidade de $p<0,05$. 



\section{Resultados}





\section{Resultados}

\subsection{Apontamentos sobre o território em estudo}

As primeiras incursões de povoamento não indígena do território que viria a se tornar o Mato Grosso remontam ao início do século XVIII, com a exploração do ouro. Durante o período colonial, a capitania de São Paulo compreendia a área do Mato Grosso, que tinha seus sistemas produtivos baseados nas atividades de exploração de minerais preciosos, na agricultura da cana-de-açúcar e erva-mate, no extrativismo da borracha e na pecuária extensiva. No século XIX, com a decadência do ciclo minerador, os produtos da pecuária e da agricultura tomam lugar principal na economia de Mato Grosso, passando a ocorrer um paulatino isolamento do norte da província. Na época, o único meio de transporte da região era o navio.

Ainda na primeira metade do século $X X$, o isolamento econômico do Mato Grosso é rompido com a ampliação da rede de comunicações para a região, representada pela instalação de vias telegráficas, aumento da navegação a vapor e abertura de estradas, cujos investimentos em infraestrutura já atraíram grande quantidade de migrantes.

O Mato Grosso, assim como toda a região Centro-Oeste (Figura 4.1), foi objeto da política governamental de interiorização do desenvolvimento, entre os anos de 1940 e 1950, e da política de integração nacional da década de 1970. A primeira foi marcada pela abertura de estradas de 
rodagem e pela construção da nova capital federal, Brasília; e, a segunda, pelos incentivos governamentais para grandes projetos agropecuários e de extrativismo, além de investimentos em produção de energia e comunicações, sobretudo hidrelétricas e estradas de rodagem.

Figura 4.1 - Região Centro-Oeste, Brasil

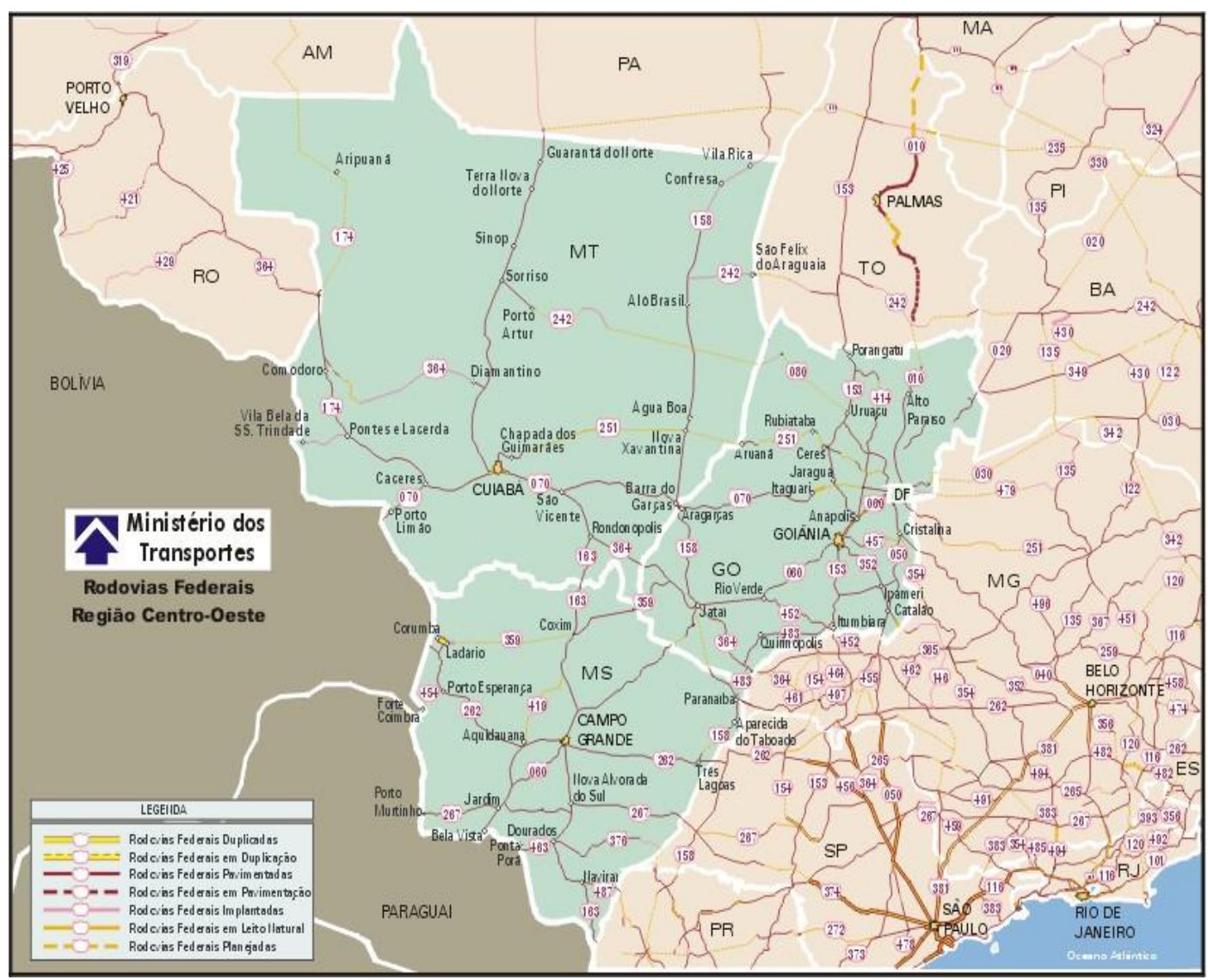

FONTE: Brasil. Ministério dos Transportes (Brasil, 2011a).

Em 1977 o governo federal decreta a divisão do estado, desmembrando-o em duas partes. Ao norte, menos populoso e desenvolvido, com menor estrutura econômica e sustentado pela 
agropecuária extensiva, delimita-se o novo Mato Grosso. Ao sul, na porção territorial mais próspera e mais populosa, ficaria estabelecido o Mato Grosso do Sul; estado atualmente com alguns indicadores socioeconômicos traduzindo condições gerais de vida um pouco mais favoráveis que no Mato Grosso (Tabela 4.1).

Nascimento (2001) aponta que o registro do primeiro caso de hanseníase no Mato Grosso foi em 1773, na Vila Bela da Santíssima Trindade, hoje constituída na cidade de Cuiabá. A atividade mineradora da região atraiu muitos braços por um longo período, fazendo surgir núcleos de povoamento, que deram origem a várias cidades. A disseminação da hanseníase foi rápida e já se notava seu crescimento mais acentuado entre escravos e pobres livres. Em 1910 a hanseníase já era vista como um grave problema de saúde pública na região. Em 1922 é instituído o Serviço de Profilaxia Rural, que teria a responsabilidade de inspecionar os domicílios; tarefa que revelou um contingente expressivo de doentes em todo o estado.

Tabela 4.1 - Caracte rização socioeconômica geral, Mato Grosso e Mato Grosso do Sul

\begin{tabular}{lcc}
\hline \multicolumn{1}{c}{ Indicador } & $\begin{array}{c}\text { Mato } \\
\text { Grosso }\end{array}$ & $\begin{array}{c}\text { Mato Grosso } \\
\text { do Sul }\end{array}$ \\
\hline $\begin{array}{l}\text { Índice de Desenvolvimento } \\
\text { Humano - IDH }\end{array}$ & 0,796 & 0,82 \\
Esperança de vida (anos) 2 & 73,7 & 74,3 \\
$\begin{array}{l}\text { Mortalidade Infantil (óbitos em } \\
\text { menores de um ano por mil } \\
\text { nascidos vivos) } 2\end{array}$ & 19,2 & 16,9 \\
Razão de dependência (\%) 3 & & 0,67 \\
\hline
\end{tabular}

FONTE:

1 Organização das Nações Unidas - ONU (2008)

z Instituto Brasileiro de Geografia e Estatística - IBGE (2010a)

3 Instituto Brasileiro de Geografia e Estatística - IBGE (2008) 


\section{Mato Grosso}

O Mato Grosso, cuja capital é Cuiabá, compõe o espaço da Amazônia Legal brasileira. Está situado no hemisfério Sul, de $7^{\circ}$ a $17^{\circ}$ de latitude e entre $50^{\circ}$ e $61^{\circ}$ de longitude Oeste; na região Centro-Oeste (Figura 4.1) e compreende cerca de 10\% do território nacional. Segundo a Organização das Nações Unidas - ONU (2008), na classificação pelo IDH, entre os 27 estados brasileiros, o MT em 2005 estava colocado em 10ํํㄱ lugar (Tabela 4.1).

Em 2009, a esperança de vida e a mortalidade infantil atingiam valores pouco melhores que a média brasileira (Tabela 4.1), que foram, respectivamente, de 73,1 anos e 22,5 óbitos em menores de um ano por mil nascidos vivos (IBGE, 2010a). No ano 2000, o quantitativo de pessoas abaixo de 15 anos era de $31,8 \%$ e o de 60 anos ou mais era de $7,3 \%$. A razão de dependência total da população atingiu valor de nove pontos percentuais acima da média nacional (IBGE, 2008).

Mesmo após o desmembramento, o estado permanece como um dos maiores do Brasil em extensão territorial e com a menor densidade demográfica da região Centro-Oeste (Tabela 4.8). Em 2000, o MT concentrou $1,5 \%$ da população brasileira, sendo o povoamento bastante heterogêneo; a densidade demográfica tem se mantido menor ao norte, em torno de 1,8 hab./km²; e, mais elevada na área de Cuiabá, que atinge 120 hab. $/ \mathrm{km}^{2}$. 
O relevo é de planalto e chapadas no centro; de planície com depressões inundadas pelo Rio Paraguai e seus afluentes, a oeste; e, planaltos residuais, a norte. O clima no norte do MT é tropical superúmido de monção, típico da Amazônia; as temperaturas são elevadas, com média anual ultrapassando $26{ }^{\circ} \mathrm{C}$. $\mathrm{O}$ índice de chuvas anuais chega a $2.000 \mathrm{~mm}$. Ao sul prevalece o clima tropical, com médias térmicas anuais de $23{ }^{\circ} \mathrm{C}$ e pluviosidade média anual de $1.500 \mathrm{~mm}$. O relevo pouco acidentado do planalto mato-grossense favorece o desenvolvimento das atividades de pecuária e agricultura mecanizadas e o alto grau de insolação e a regularidade das chuvas torna o clima de Mato Grosso apropriado a diversas culturas.

A maior parte da superfície ao norte do estado é coberta por floresta equatorial, como um prolongamento do bioma amazônico. Ao sul encontrase o cerrado e a leste o pantanal, onde predominam coberturas gramíneas, muito usadas como pastagem. A zona de floresta compreende $47 \%$ da área total, os cerrados $39 \%$ e os campos $14 \%$.

Entre 1940 e 2000, a população do estado aumentou treze vezes. Na década de 1960 o MT passa a apresentar taxas de crescimento populacional acima da média do Centro-Oeste, alcançando um pico na década de 1970, com $6,64 \%$ ao ano e daí em diante decai, mas mantendo-se ainda, na década de 2000 , com 1,94\% ao ano, acima da média nacional e regional.

Em 1980 a população do MT era de 1.138 .918 habitantes e em 2010 chega a 3.033.991 habitantes (IBGE, 2011), sendo que maiores crescimentos populacionais têm sido registrados nas áreas onde a expansão 
da produção de grãos em escala comercial é recente, como a que compreende os municípios de Sorriso e Sinop.

A população não natural do MT, que era de $46 \%$ em 1991, sofre uma queda relativa para 43\% em 2000 (IBGE, 2008), representando uma média acima da verificada no Centro-Oeste $(35 \%)$ e para o país como um todo (16\%).

A adoção de uma forte política de benefícios fiscais estimulou o desenvolvimento da agroindústria local e modificou o perfil rural das cidades do MT e fez com que sua economia crescesse a um ritmo superior à média nacional. De 1977 a 2007, a área plantada aumentou quatro vezes e a produção da lavoura quase oito vezes. A "explosão agrícola" andou junto com a multiplicação do número de cidades. Entre os anos de 1980 e 2000, o MT ganhou 71 novos municípios, passando de 55 para 126 no total (IBGE, 2008). Nos novos municípios, a maioria da população adulta é composta por migrantes nascidos em outros estados. No MT há uma grande concentração de terras: as grandes propriedades, com mais de mil hectares, representam $10 \%$ dos estabelecimentos agropecuários e ocupam $82 \%$ do território.

No ano 2000 , a população acima de 10 anos ocupada na atividade principal foi da ordem de 1.016 .725 pessoas, distribuídas entre as atividades de agricultura, pecuária, silvicultura e de pesca, 23\%; indústria extrativa e de transformação, 11\%; e, comércio, construção e outros serviços, 66\% (IBGE, 2008).

O PIB estadual em 2008 foi de 53 bilhões de reais, um número que representa $1,7 \%$ do PIB nacional. O setor agropecuário participou da 
economia do MT em 2008 com 29\% do volume do valor adicionado (IBGE, 2009).

A economia do MT está voltada majoritariamente para exportações de produtos primários, agropecuários e minerais, sendo o maior produtor nacional de carne bovina, soja e algodão. Em 2000, a balança comercial teve um bilhão de dólares em exportações e 91 milhões de dólares em importações (Brasil, 2011b).

$\mathrm{Na}$ área de transportes, o MT conta com a linha ferroviária da Ferronorte, inaugurada no ano de 2000; e, ligações multimodais entre rodovias, ferrovias e hidrovias utilizadas principalmente como corredores de escoamento de produtos agrícolas.

\section{Mato Grosso do Sul}

O Mato Grosso do Sul localiza-se entre as latitudes $17^{\circ}$ e $24^{\circ}$ Sul e as longitudes $50^{\circ}$ e $58^{\circ}$ Oeste, na região Centro-Oeste do Brasil (Figura 4.1). Tem como capital política o município de Campo Grande. Em 2005 o MS alcançou um IDH (Tabela 4.1) que o posicionava em $7^{\circ}$ lugar entre os estados brasileiros (ONU, 2008). Possui extensão que corresponde a $4 \%$ do território brasileiro (Tabela 4.8). Em 1980 o MS contava com 55 municípios e em 2000 chegou a um total de 77 municípios (IBGE, 2008). No ano 2000, o número de habitantes abaixo de 15 anos representava $30,6 \%$ da população e de 60 anos ou mais somavam a proporção de 9,5\%; a razão de dependência foi pouco acima da apurada para o MT (Tabela 4.1). 
No MS há predomínio do clima tropical, com chuvas de verão e inverno seco; uma média anual pluviométrica de $1.500 \mathrm{~mm}$ e temperatura de 20 a $25{ }^{\circ} \mathrm{C}$. O relevo do planalto da bacia do Rio Paraná ocupa toda a porção leste do MS, com extensas superfícies planas. Vinte e cinco por cento da área do MS é ocupada por depressões de terras, que formam uma planície aluvial sujeita a inundações periódicas, a planície do Pantanal, localizada a leste. A vegetação de cerrados recobre a maior parte do território.

Entre a década de 1940 e 2000, a população do MS aumentou nove vezes, ao passo em que a população do Brasil, no mesmo período, aumentou quatro vezes. Em 2009, a esperança de vida no MS e a mortalidade infantil alcançavam cifras pouco mais favoráveis que as observadas no MT (Tabela 4.1).

Migrações internas e de estrangeiros, principalmente paraguaios e bolivianos, estiveram povoando o sul mato-grossense ao lado dos habitantes ameríndios. A partir de 1940, o processo de colonização fomentado na "Marcha para o Oeste", promovido durante a ditadura de Getúlio Vargas, intensificou a corrente migratória em direção à região. Na década de 1970, um novo fluxo migratório, sobretudo de origem sulista, esteve direcionado para o sul mato-grossense, com padrões de colonização relacionados a atividades agrícolas, principalmente em função de investimentos em culturas mecanizadas de cereais como soja e arroz. A partir da última década do século XX, nota-se uma redução das imigrações estaduais e no saldo migratório (IBGE, 2008). 
Na década de 1950 o MS apresentou uma taxa de crescimento populacional de $6,2 \%$ ao ano, acima da média nacional e regional. Desde a década de 1960 esta taxa vem decaindo e permanecendo abaixo da observada para a região Centro-Oeste, atingindo para a década de 2000 a taxa de 1,7\% ao ano, mesmo assim, ainda acima da média nacional, de 1,2\%. Em 1980 a população do MS era de 1.369 .769 habitantes e em 2010 chega a 2.449.341 habitantes (IBGE, 2011).

A população residente não natural do MS, que era de 32\% em 1991, passa a representar $28 \%$ do contingente demográfico em 2000 (IBGE, 2008); uma proporção abaixo da média regional e acima da nacional.

A infraestrutura econômica do MS e sua localização geográfica estratégica têm contribuído para consolidar o estado como um pólo de redistribuição de produtos oriundos dos grandes centros econômicos do país para o restante da região Centro-Oeste e região Norte do Brasil. A malha de transporte conta com hidrovias, ferrovias e rodovias que oferecem comunicação com os países do cone sul do continente, por meio da bacia do Rio da Prata, colocam o estado em acesso do Oceano Atlântico ao Pacífico, via países andinos.

No ano 2000, a população acima de 10 anos ocupada na atividade principal foi de 844.261 pessoas, distribuídas entre atividades agrícolas, pecuárias, de silvicultura e pesca, 20\%; indústria extrativa e de transformação, 9\%; e, comércio, construção e outros serviços, 71\% (IBGE, 2008). 
A atividade agropecuária e de extração vegetal e mineral, proporcionaram um acelerado desenvolvimento da região a partir do século XIX. As principais fontes econômicas, atualmente, correspondem à produção rural (animal, vegetal, extrativa vegetal e indústria rural), extração mineral, turismo e prestação de serviços. A região econômica mais desenvolvida situa-se ao sul do MS. O PIB estadual em 2008 foi de 33 bilhões de reais, representando 1,1\% do PIB nacional. A base econômica é predominantemente agropecuária, setor responsável por $17 \%$ do valor adicionado do estado em 2008 (IBGE, 2009). No ano de 2000, a balança comercial do MS teve 253 milhões de dólares em exportações e 161 milhões de dólares em importações (Brasil, 2011b).

\subsection{Descrição epidemiológica}

Entre residentes do Mato Grosso e do Mato Grosso do Sul foram detectados no período de 2000 a 2006, um total de 28.166 casos de hanseníase, correspondendo a $8,4 \%$ dos casos diagnosticados no Brasil. Em um universo de 203 municípios, Selvíria, no Mato Grosso do Sul, não registrou caso de hanseníase. Pelo menos 50\% dos municípios notificaram, entre residentes, mais de 48 casos e pelo menos $10 \%$ deles informaram acima de 250 casos no período.

Quanto ao local de atendimento, no MT, em 2001, cinco municípios com registro de caso entre residentes, não apontaram atendimento no 
município; em 2006, este número foi de apenas um município. No MS, estes números foram, respectivamente, de 23 e três municípios.

Globalmente, a área em estudo apresentou uma taxa de detecção média anual de hanseníase de 8,4 casos/10.000 habitantes, com uma mediana de 7,5 casos/10.000 habitantes. A taxa de detecção por estado foi de 12,8 casos/10.000 hab. no MT e 2,9 casos/10.000 hab. no MS.

Considerando apenas os municípios que registraram casos de hanseníase, o município do MT que apresentou menor taxa de detecção foi Araguainha (1,1 casos / 10.000 hab.) e a maior taxa foi apurada em Diamantino (41,3 casos / 10.000 hab.); para o MS estas taxas foram 0,7 (Japorã) e 12,2 (Naviraí), respectivamente. A mediana da taxa de detecção para os municípios do MT esteve em 12,4 casos / 10.000 habitantes e 2,4 casos / 10.000 habitantes no MS.

A taxa de detecção no sexo masculino foi maior do que no feminino; na faixa etária de 50 anos e mais, a taxa de detecção foi superior à conferida para as demais; e, a razão de casos, segundo a classificação operacional da forma clínica, pendeu para os paucibacilares (Anexo).

Oito municípios apresentaram taxas de detecção média anual abaixo de 1,0 caso / 10.000 hab. e 137 municípios apresentaram taxa de detecção acima de 4,0 casos / 10.000 habitantes, dos quais 14 pertencem ao MS; correspondendo a um contingente populacional exposto à hiperendemicidade de 3.021 .707 pessoas ou $63 \%$ da população estudada. Todos os municípios do último quintil de endemicidade pertencem ao MT (Anexo; Mapa 4.1). 
Foram diagnosticados no período em estudo 15.161 casos da classe operacional da forma clínica paucibacilar e 12.928 da forma multibacilar; em 77 casos a forma clínica esteve ignorada. Em 98 municípios predominaram os casos paucibacilares, sendo este mesmo quantitativo de municípios encontrado com predomínio de multibacilares (Anexo).

Em números absolutos, houve predomínio de casos do sexo masculino $(57,9 \%)$ em relação ao feminino. Em termos de taxa de detecção, pelo menos em 168 municípios (82,8\%) as taxas de detecção de hanseníase no sexo masculino superaram as observadas no sexo feminino (Anexo).

A maioria dos casos incidentes pertence à faixa etária de 15 a 49 anos $(65,7 \%)$, seguida por 50 anos ou mais $(27,3 \%)$ e menor de 15 anos de idade $(7,0 \%)$. Noventa e nove municípios tiveram taxas de detecção média anual acima de 1,0 caso / 10.000 hab. entre menores de 15 anos de idade, sendo sete deles no MS (Anexo).

$\mathrm{Na}$ escala estadual, nota-se que a taxa bruta de detecção é quatro vezes maior no MT. As diferenças nas taxas de detecção entre os estados são mais relevantes na faixa etária de menos de 15 anos. A taxa de detecção aumenta com a faixa etária, em ambos os sexos, fato que se repete nos dois estados (Tabela 4.2).

Os casos paucibacilares predominam até a faixa etária dos 15 a 49 anos de idade, a partir daí os multibacilares foram mais incidentes, observando-se a mesma viragem da taxa de detecção em ambos os estados (Tabela 4.3). Em 50 municípios hiperendêmicos, que diagnosticaram mais 
de 10 casos entre residentes de 15 a 49 anos, notou-se predomínio de multibacilares nesta faixa etária; entre os quais, cinco pertencem ao MS.

Mapa 4.1 - Taxa de deteç̧ão média anual de hanseníase (casos/10.000 hab.), segundo o município de residência, Mato Grosso e Mato Grosso do Sul - 2000-2006

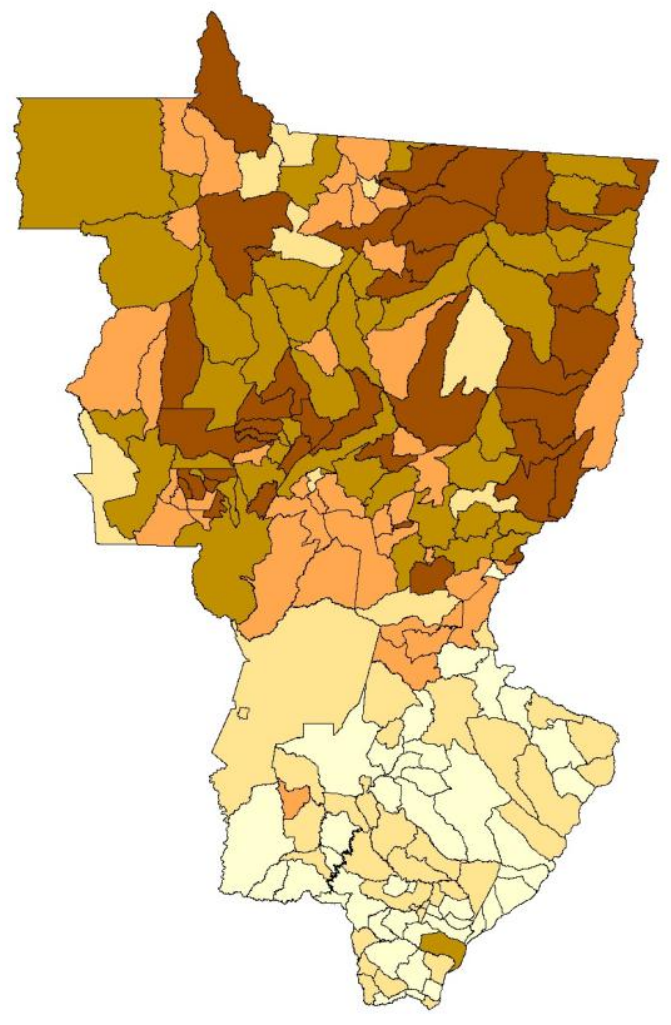

Taxa de detecção Classes em igual frequência

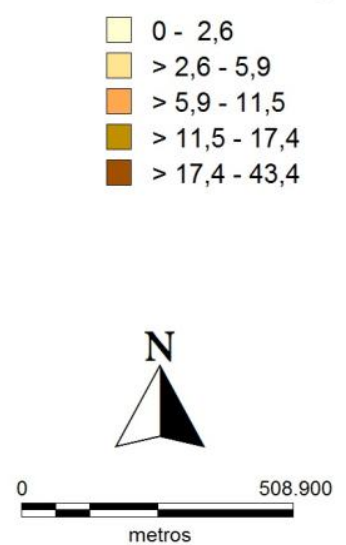

FONTE: Datasus, SINAN - Ministério da Saúde; Estimativas populacionais 2003 - IBGE

Em cinco municípios com níveis de detecção acima de 1,0 casos/10.000 hab. em menores de 15 anos e mais de 10 casos diagnosticados na faixa etária, houve predomínio de multibacilares, foram 
eles: Alto Paraguai, Barra do Garças, Chapada dos Guimarães, Primavera do Leste e Vera.

No sexo masculino nota-se maior incidência das formas multibacilares e no sexo feminino são as formas paucibacilares que predominam, com este padrão se repetindo no MT e no MS (Tabela 4.4).

Analisando a taxa de detecção na faixa etária de 50 anos e mais, observa-se que no MS e no MT ela é maior no sexo masculino para multibacilares, enquanto que no sexo feminino a taxa de detecção de paucibacilares se sobressai (Tabela 4.5).

A razão de incidência entre MT e MS é maior em multibacilares do sexo masculino com menos de 15 anos. O contraste das taxas de detecção entre MT e MS diminui na medida em que avança a faixa etária, tanto no sexo masculino como no feminino, seja na forma paucibacilar ou multibacilar (Tabela 4.5).

\begin{tabular}{|c|c|c|c|c|}
\hline \multirow{2}{*}{ UF } & \multirow{2}{*}{ Faixa etária } & \multicolumn{2}{|c|}{ Sexo } & \multirow{2}{*}{ Total } \\
\hline & & Masculino & Feminino & \\
\hline \multirow{4}{*}{ Mato Grosso } & $<15$ anos & 3,14 & 2,91 & 3,03 \\
\hline & $15-49$ anos & 16,96 & 13,51 & 15,28 \\
\hline & 50 anos ou mais & 32,38 & 21,89 & 27,51 \\
\hline & Total & 14,51 & 11,06 & 12,84 \\
\hline \multirow{4}{*}{ Mato Grosso do Sul } & $<15$ anos & 0,35 & 0,46 & 0,41 \\
\hline & $15-49$ anos & 3,41 & 2,70 & 3,05 \\
\hline & 50 anos ou mais & 8,79 & 5,71 & 7,25 \\
\hline & Total & 3,24 & 2,46 & 2,85 \\
\hline
\end{tabular}

FONTE: Datasus, SINAN - Ministério da Saúde; Estimativas populacionais 2003 IBGE 
O registro sobre a avaliação de incapacidades no momento do diagnóstico ocorreu em maior proporção de casos no MT; e, a presença de comprometimento físico foi detectada em maior proporção no MS (Tabela 4.6).

Tabela 4.3 - Taxa de deteç̧ão média anual de casos de hanseníase por 10 mil habitantes, segundo a faixa etária e classe operacional da forma clínica, Mato Grosso e Mato Grosso do Sul - 2000 a 2006

\begin{tabular}{|c|c|c|c|}
\hline \multirow{2}{*}{ UF } & \multirow{2}{*}{ Faixa etária } & \multicolumn{2}{|c|}{ Classe operacional } \\
\hline & & Paucibacilar & Multibacilar \\
\hline & $<15$ anos & 2,20 & 0,82 \\
\hline & $15-49$ anos & 8,64 & 6,60 \\
\hline \multicolumn{4}{|l|}{ Mato Grosso } \\
\hline & 50 anos ou mais & 12,06 & 15,41 \\
\hline & Total & 7,00 & 5,81 \\
\hline & $<15$ anos & 0,31 & 0,10 \\
\hline & $15-49$ anos & 1,62 & 1,41 \\
\hline \multicolumn{4}{|c|}{ Mato Grosso do Sul } \\
\hline & 50 anos ou mais & 3,04 & 4,19 \\
\hline & Total & 1,43 & 1,41 \\
\hline
\end{tabular}

FONTE: Ministério da Saúde, Datasus, SINAN; IBGE, Estimativas populacionais -2003 
Tabela 4.4 - Taxa de detecção média anual de casos de hanseníase por 10 mil habitantes, segundo o sexo e classe operacional da forma clínica, Mato Grosso e Mato Grosso do Sul - 2000 a 2006

\begin{tabular}{ccrc}
\hline \multirow{2}{*}{ UF } & Sexo & \multicolumn{2}{c}{ Classe operacional } \\
\cline { 3 - 4 } & & Paucibacilar & Multibacilar \\
\hline \multirow{2}{*}{ Mato Grosso } & Masculino & 6,78 & 7,70 \\
& Feminino & 7,23 & 3,80 \\
\hline \multirow{2}{*}{ Mato Grosso do Sul } & Masculino & 1,32 & 1,90 \\
& Feminino & 1,54 & 0,92 \\
\hline
\end{tabular}

FONTE: Datasus, SINAN - Ministério da Saúde; Estimativas populacionais 2003 - IBGE

Tabela 4.5 - Razão de taxas de deteç̧ão entre Mato Grosso e Mato Grosso do Sul, segundo a classe operacional da forma clínica, sexo e faixa etária, 2000 - 2006

\begin{tabular}{|c|c|c|c|c|c|}
\hline \multirow{2}{*}{$\begin{array}{c}\text { Classe } \\
\text { operacional }\end{array}$} & \multirow{2}{*}{ Sexo } & \multirow{2}{*}{ Faixa etária } & \multicolumn{2}{|c|}{$\begin{array}{l}\text { Taxa de detecção } \\
\text { (por 10.000 hab_) }\end{array}$} & \multirow{2}{*}{$\begin{array}{l}\text { Razão de } \\
\text { taxas de } \\
\text { deteç̧ão }\end{array}$} \\
\hline & & & Mato Grosso & $\begin{array}{l}\text { Mato Grosso } \\
\text { do Sul }\end{array}$ & \\
\hline \multirow{6}{*}{ Paucibacilar } & \multirow{3}{*}{ Masculino } & Menos de 15 anos & 2,18 & 0,26 & 7,33 \\
\hline & & 15-49 anos & 8,24 & 1,49 & 5,53 \\
\hline & & 50 anos ou mais & 11,87 & 2,94 & 4,04 \\
\hline & \multirow{3}{*}{ Feminino } & Menos de 15 anos & 2,22 & 0,36 & 6,10 \\
\hline & & $15-49$ anos & 9,06 & 1,75 & 5,17 \\
\hline & & 50 anos ou mais & 12,28 & 3,15 & 3,90 \\
\hline \multirow{6}{*}{ Multibacilar } & \multirow{3}{*}{ Masculino } & Menos de 15 anos & 0,94 & 0,09 & 10,14 \\
\hline & & $15-49$ anos & 8,68 & 1,89 & 4,59 \\
\hline & & 50 anos ou mais & 20,48 & 5,82 & 3,52 \\
\hline & \multirow{3}{*}{ Feminino } & Menos de 15 anos & 0,69 & 0,10 & 6,87 \\
\hline & & 15-49 anos & 4,41 & 0,94 & 4,71 \\
\hline & & 50 anos ou mais & 9,56 & 2,56 & 3,74 \\
\hline
\end{tabular}

FONTE: Datasus, SINAN - Ministério da Saúde; Estimativas populacionais 2003 - IBGE

No MS, de 46 municípios que tiveram avaliação de incapacidades físicas em $75 \%$ ou mais dos casos recém diagnosticados, 23 tiveram mais 
de $5 \%$ dos casos avaliados com grau II de incapacidade física ao diagnóstico. No MT, estes números foram, respectivamente, 113 e 32 municípios.

\begin{tabular}{|c|c|c|c|c|c|c|c|c|}
\hline \multirow{2}{*}{ UF } & \multicolumn{2}{|c|}{ Presente } & \multicolumn{2}{|c|}{ Ausente } & \multicolumn{2}{|c|}{$\begin{array}{l}\text { Ignorada ou } \\
\text { não avaliada }\end{array}$} & \multicolumn{2}{|c|}{ Total } \\
\hline & $\mathbf{n}$ & $\%$ & $\mathbf{n}$ & $\%$ & n & $\%$ & $\mathbf{n}$ & $\%$ \\
\hline Mato Grosso & 3.875 & 16,26 & 16.984 & 71,26 & 2.975 & 12,48 & 23.834 & 100,00 \\
\hline Mato Grosso do Sul & 787 & 18,17 & 2.683 & 61,93 & 862 & 19,90 & 4.332 & 100,00 \\
\hline
\end{tabular}

FONTE: Datasus, SINAN - Ministério da Saúde

\subsection{Descrição sociodemográfica}

No ano de 2003, a população do Mato Grosso e Mato Grosso do Sul, juntas, representavam uma proporção de $2,7 \%$ da população brasileira (IBGE, 2007). Quanto ao tamanho populacional dos municípios, 75\% deles tinham menos de 18 mil habitantes, sendo que juntos totalizavam $29 \%$ da população da área em estudo. Comparando as duas UF, o MT possui maior proporção da população em municípios abaixo da mediana de tamanho populacional (Tabela 4.14).

A população do MT supera a do MS em quase meio milhão de habitantes, mas com estreitas diferenças na proporção entre sexos e faixas 
etárias (Tabela 4.7). Municípios com maiores proporções de jovens com menos de 15 anos de idade foram identificados no MT.

$\mathrm{Na}$ área em estudo, a diferença do contingente populacional a favor do sexo masculino é menor do que 2\%. Em 90\% dos municípios ocorre predomínio demográfico masculino e os municípios com maior proporção de população do sexo masculino foram encontrados no MT.

A densidade demográfica do MS foi superior ao dobro da observada no MT (Tabela 4.8). A densidade demográfica entre os municípios variou amplamente. Gaúcha do Norte, no MT, apresentou 0,3 hab./km², enquanto Várzea Grande, no mesmo estado, 238,8 hab./km². No conjunto, $90 \%$ dos municípios apresentaram densidade demográfica abaixo de 9,5 hab./ $\mathrm{km}^{2}$.

Em $75 \%$ dos municípios a população urbana é maior do que a população rural. Municípios com menores proporções de população urbana estão situados no MT (Tabela 4.14).

Mato Grosso apresentou crescimento populacional no período entre o ano de 1991 e 2000 acima do observado para o Mato Grosso do Sul, concentrando municípios com as maiores taxas de crescimento populacional (Tabela 4.8; Mapa 4.2). Vinte e cinco por cento dos municípios apresentaram crescimento populacional acima de $3,54 \%$ ao ano (Tabela 4.14 ).

No ano 2000, o PIB per capita e a taxa de desemprego no MS estiveram acima das cifras observadas no MT; e, a renda média familiar mensal foi inferior à atingida no MT (Tabela 4.9). 
Tabela 4.7 - População segundo a faixa etária e o sexo, Mato Grosso e Mato Grosso do Sul - 2003

\begin{tabular}{llrrr}
\hline \multirow{2}{*}{ UF } & \multirow{2}{*}{ Faixa etária } & \multicolumn{2}{c}{ Sexo } & \multirow{2}{*}{ Total } \\
\cline { 3 - 4 } & & Masculino & Feminino & \\
\hline \multirow{3}{*}{ Mato Grosso } & $<15$ anos & 430.272 & 413.169 & 843.441 \\
& $15-49$ anos & 764.091 & 728.033 & 1.492 .124 \\
& 50 anos ou mais & 168.953 & 146.795 & 315.748 \\
\cline { 2 - 4 } & Total & 1.363 .316 & 1.287 .997 & 2.651 .313 \\
\hline \multirow{3}{*}{ Mato Grosso do Sul } & $15-49$ anos & 538.033 & 326.378 & 664.411 \\
& 50 anos ou mais & 157.605 & 156.963 & 314.568 \\
\cline { 2 - 4 } & Total & 1.085 .733 & 1.083 .971 & 2.169 .704 \\
\hline
\end{tabular}

FONTE: Estimativas populacionais 2003 - IBGE

Cinquenta e seis por cento da população residem em municípios que apresentaram renda média familiar mensal acima de 963 reais, sendo este número de $51 \%$ para o MS e $53 \%$ para o MT (Tabela 4.14).

O Produto Interno Bruto (PIB) per capita dos municípios para o ano 2000 teve uma mediana de 4.588 reais/hab. e abrangeu valores entre Sapezal, no MT, com 26.979 reais/hab. e Ladário, no MS, com 1.725 reais por habitante. No MS, $80 \%$ da população estão acima da mediana do PIB per capita, enquanto no MT, 50\% estão acima da mediana (Tabela 4.14). 
Tabela 4.8 - População residente em 1991 e população residente em 2000, por situação do domicílio, taxa de crescimento populacional, área total e densidade demográfica, Mato Grosso e Mato Grosso do Sul

\begin{tabular}{|c|c|c|c|}
\hline \multicolumn{2}{|c|}{ Indicador } & Mato Grosso do Sul & Mato Grosso \\
\hline \multicolumn{2}{|c|}{ População residente em 01.09.1991 } & 1780373 & 2027231 \\
\hline & Total & 2074877 & 2502260 \\
\hline \multirow{3}{*}{$\begin{array}{l}\text { População residente } \\
\text { em } 01.08 .2000\end{array}$} & Urbana & 1744520 & 1985590 \\
\hline & Rural & 330357 & 516670 \\
\hline & Proporção urbana (\%) & 84,08 & 79,35 \\
\hline \multicolumn{2}{|c|}{$\begin{array}{l}\text { Taxa média geométrica anual de crescimento } \\
\text { populacional 1991/2000 (\% ao ano) }\end{array}$} & 1,75 & 2,40 \\
\hline \multicolumn{2}{|c|}{ Área total em 01.08.2000 (km²) } & 357140 & 903386 \\
\hline \multicolumn{2}{|c|}{$\begin{array}{l}\text { Densidade demog ráfica em 01.08.2000 } \\
\left(\mathrm{hab} / \mathrm{km}^{2}\right)\end{array}$} & 5,81 & 2,77 \\
\hline
\end{tabular}

FONTE: Censos Demográficos 1991 e 2000 - IBGE

A fração da população com 10 anos ou mais de idade variou de 70,5\% em Japorã (MS); até 85,0\% em Vicentina (MS). A proporção referente à população com 10 anos ou mais de idade, economicamente ativa, variou de $26,5 \%$ em General Carneiro (MT), a 57,2\% em Nova Lacerda (MT). A taxa de desemprego, representada pelo percentual da população economicamente ativa não ocupada na atividade principal, teve seu limite superior no município de Guia Lopes da Laguna - MS $(9,2 \%)$ e inferior em Castanheira - MT (0,9\%). Sessenta e nove por cento da população do MS reside em município com taxa de desemprego situada no último quartil; no MT, este quartil é ocupado por $46 \%$ da população (Tabela 4.14). 
A proporção da população com 10 anos ou mais de idade sem instrução ou com menos de quatro anos de estudo foi semelhante entre os dois estados, em torno de 23\% (Tabela 4.10); na escala municipal esta proporção variou do patamar de mais de $40 \%$, como nos municípios de Barão de Melgaço (MT) e Japorã (MS), a menos de 16\%, como nas capitais, Cuiabá (MT) e Campo Grande (MS). A mediana dos municípios quanto à proporção da população com 10 anos ou mais de idade sem instrução ou com menos de quatro anos de estudo foi de $30 \%$ (Tabela 4.14).

Em 2000, a proporção da população moradora em domicílios com seis ou mais pessoas esteve em $17,4 \%$ e a mediana de municípios esteve situada em $18,6 \%$. Trinta e seis por cento da população do MT esteve situada acima da mediana, enquanto no MS este número atingiu $23 \%$ (Tabela 4.14).

Para o percentual de pessoas em domicílios com média superior a três pessoas por dormitório, os estados apresentaram índices próximos (Tabela 4.11); para o conjunto dos municípios em estudo, a mediana foi de $11,5 \%$. No MT, $65 \%$ da população encontram-se no último quartil deste indicador, contra $33 \%$ observado no MS (Tabela 4.14).

A mediana de municípios para a proporção da população em domicílios sem banheiro foi de 22\%; com o MT chegando a uma média próxima ao dobro da observada para o MS e sua população concentrada nos quartis superiores (Tabelas 4.11 e 4.14).

A mediana de municípios quanto à proporção populacional de não naturais da UF esteve em $41 \%$; enquanto $2 \%$ da população do MS residem 
em municípios do último quartil, este valor chega a 30\% no MT. Para a proporção de imigrantes nos últimos 10 anos na população, a mediana foi de 10\%; estando o último quartil ocupado por $25 \%$ da população do MT e $3 \%$ do MS (Tabela 4.14).

Mapa 4.2 - Taxa média anual de crescimento geométrico populacional (\% a.a.), municípios do Mato Grosso e Mato Grosso do Sul - 1991/2000

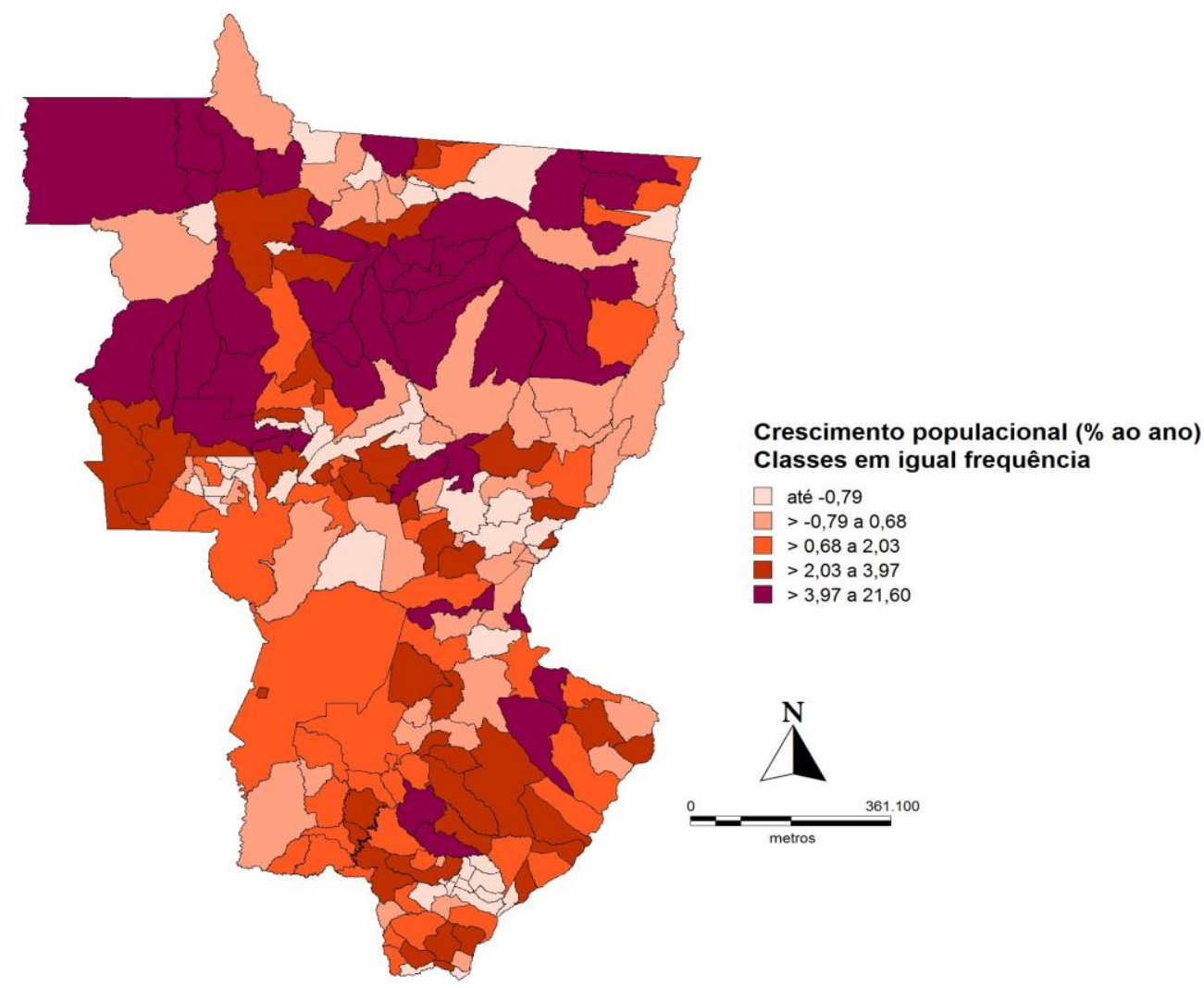

FONTE: Censos demográficos - IBGE 
Com relação à proporção da população não natural da UF e imigrante nos últimos 10 anos, índices mais elevados foram encontrados no MT (Tabela 4.12).

A cobertura populacional da estratégia de Atenção "Saúde da Família" (ESF) atingiu maiores proporções no MT, assim como a média de consultas médicas em clínicas básicas, oferecidas ao ano, por habitante, pelo SUS, foi superior àquela alcançada no MS (Tabela 4.13).

Tabela 4.9 - Produto interno bruto per capita, taxa de desemprego e rendimento nominal médio mensal familiar, Mato Grosso e Mato Grosso do Sul - 2000

\begin{tabular}{|c|c|c|c|}
\hline \multicolumn{2}{|c|}{ Indicador } & \multirow{2}{*}{$\frac{\text { Mato Grosso do Sul }}{11861168}$} & \multirow{2}{*}{ Mato Grosso } \\
\hline Produto Interno Bruto (1) & $\begin{array}{l}\text { A preço de mercado } \\
\text { corrente (1 } 000 \mathrm{R} \$)\end{array}$ & & \\
\hline & Per capita $(R \$)$ & 5656 & 5297 \\
\hline \multirow{2}{*}{$\begin{array}{l}\text { Pessoas de } 10 \text { anos ou mais de } \\
\text { idade (2) }\end{array}$} & $\mathrm{n}$ & 1658782 & 1982014 \\
\hline & $\%$ & 79,8 & 79,1 \\
\hline \multirow{2}{*}{$\begin{array}{l}\text { Pessoas de } 10 \text { anos ou mais de } \\
\text { idade, economicamente ativas } \\
\text { (2) }\end{array}$} & $\mathrm{n}$ & 978222 & 1159135 \\
\hline & $\%$ & 47,1 & 46,3 \\
\hline \multirow{2}{*}{$\begin{array}{l}\text { Pessoas de } 10 \text { anos ou mais de } \\
\text { idade, economicamente ativas, } \\
\text { não ocupadas (2) }\end{array}$} & $\mathrm{n}$ & 133962 & 142411 \\
\hline & $\begin{array}{l}\text { Taxa de desemprego } \\
\qquad(\%)\end{array}$ & 6,45 & 5,69 \\
\hline \multicolumn{2}{|c|}{$\begin{array}{l}\text { Famílias residentes em domicîl ios particulares (Unidades) } \\
\text { (2) }\end{array}$} & 609257 & 698349 \\
\hline \multicolumn{2}{|c|}{$\begin{array}{l}\text { Valor do rendimento nominal médio mensal familiar } \\
\text { (Reais) (2) }\end{array}$} & 1029 & 1097 \\
\hline \multicolumn{4}{|c|}{$\begin{array}{l}\text { FONTE: } \\
\text { (1) IBGE, Diretoria de Pesquisas, Coor denação de Contas Nacionais } 2000\end{array}$} \\
\hline \multicolumn{3}{|c|}{ (2) IBGE, Censo Demográfico 2000} & \\
\hline
\end{tabular}


Tabela 4.10 - Pessoas sem instrução ou com menos de 4 anos de estudo, Mato Grosso e Mato Grosso do Sul - 2000

\begin{tabular}{lccc}
\hline UF & População & \multicolumn{2}{c}{$\begin{array}{c}\text { Pessoas de 10 anos ou mais de } \\
\text { idade sem instrução ou menos de 4 } \\
\text { anos de estudo }\end{array}$} \\
\cline { 3 - 4 } Mato Grosso do Sul & 2.078 .001 & 481.448 & 23,17 \\
Mato Grosso & 2.504 .353 & 593.427 & 23,70 \\
\hline
\end{tabular}

FONTE: Censo Demográfico 2000 - IBGE

Tabela 4.11 - Pessoas em domicilios particulares permanentes com mais de 6 moradores, em domicílios com mais de 3 pessoas por dormitório e em domicilios sem banheiro, Mato Grosso e Mato Grosso do Sul - 2000

\begin{tabular}{|c|c|c|c|c|c|c|c|}
\hline \multirow[t]{2}{*}{ UF } & \multirow[t]{2}{*}{ População } & \multicolumn{2}{|c|}{$\begin{array}{c}\text { Pessoas em } \\
\text { domicílios com mais } \\
\text { de } 6 \text { moradores }\end{array}$} & \multicolumn{2}{|c|}{$\begin{array}{c}\text { Pessoas em } \\
\text { domicilios com mais } \\
\text { de } 3 \text { moradores por } \\
\text { dormitório }\end{array}$} & \multicolumn{2}{|c|}{$\begin{array}{l}\text { Pessoas moradoras } \\
\text { em domicilios sem } \\
\text { banheiro }\end{array}$} \\
\hline & & n & $\%$ & $n$ & $\%$ & $\mathrm{n}$ & $\%$ \\
\hline Mato Grosso do Sul & 2.078 .001 & 321.144 & 15,45 & 269.527 & 12,97 & 230.765 & 11,11 \\
\hline Mato Grosso & 2.504 .353 & 473.986 & 18,93 & 350.633 & 14,00 & 528.210 & 21,09 \\
\hline
\end{tabular}

FONTE: Censo Demográico 2000 - IBGE 
Tabela 4.12 - Pessoas não naturais da Unidade da Federação (UF) e pessoas não naturais imigrantes nos últimos 10 anos, Mato Grosso e Mato Grosso do Sul - 2000

\begin{tabular}{|c|c|c|c|c|c|}
\hline \multirow[t]{2}{*}{ UF } & \multirow[t]{2}{*}{ População } & \multicolumn{2}{|c|}{$\begin{array}{c}\text { Pessoas não naturais da } \\
\text { UF }\end{array}$} & \multicolumn{2}{|c|}{$\begin{array}{c}\text { Pessoas não naturais da } \\
\text { UF, imigrantes nos } \\
\text { últimos } 10 \text { anos }\end{array}$} \\
\hline & & $\mathbf{n}$ & $\%$ & $\mathbf{n}$ & $\%$ \\
\hline Mato Grosso do Sul & 2.078 .001 & 588.760 & 28,33 & 176.170 & 8,48 \\
\hline Mato Grosso & 2.504 .353 & 1.066 .754 & 42,60 & 362.103 & 14,46 \\
\hline
\end{tabular}

FONTE: Censo Demográfico 2000 - IBGE

A metade dos municípios chegou a mais de $57 \%$ de cobertura da ESF; sendo que, acima deste valor, estiveram $41 \%$ da população do MT e 9\% do MS. A média de consultas médicas por habitante foi superior a 1,2 consultas ao ano em $75 \%$ dos municípios. Enquanto $52 \%$ da população do MS moravam em municípios que obtiveram uma média de pelo menos 1,7 consultas médicas ao ano, no MT este número foi de 35\% (Tabela 4.14).

Tabela 4 - 13 - Cobertura populacional médía da estratégia de Atenção Saúde da Família e média de consultas médicas do SUS em clínicas básicas por habitante ao ano, Mato Grosso e Mato Grosso do Sul - 2000 a 2006

\begin{tabular}{lcc}
\hline UF & $\begin{array}{c}\text { Cobertura da } \\
\text { Saúde da Familia } \\
(\%)\end{array}$ & $\begin{array}{c}\text { Média de consultas } \\
\text { médicas básicas } \\
\text { (cons./hab./ano) }\end{array}$ \\
\hline Mato Grosso do Sul & 30,80 & 1,67 \\
Mato Grosso & & 1,83 \\
\hline
\end{tabular}

FONTE: Indicadores do Pacto de Atenção Básica 2006, SIAB, S I A - Ministério da Saúde 
Tabela 4.14. População da área em estudo, segundo quartis de distribuição dos municípios, ordenada por indicadores sociodemográficos e composição por Unidade Federada

\begin{tabular}{|c|c|c|c|c|c|c|c|c|c|c|c|c|}
\hline \multirow{2}{*}{ Indicadores } & \multicolumn{3}{|c|}{ Percentil } & \multirow{2}{*}{ UF } & \multicolumn{4}{|c|}{ População intraquartil (habitantes) } & \multicolumn{4}{|c|}{ População intraquartil (\%) } \\
\hline & 25 & 50 & 75 & & Q1 & Q2 & Q3 & Q4 & Q1 & Q2 & Q3 & Q4 \\
\hline \multirow{3}{*}{ Tamanho populacional (habitantes) } & & & & MT e MS & 209.984 & 425.165 & 704.581 & 3.242 .624 & 4,6 & 9,3 & 15,4 & 70,8 \\
\hline & 5.881 & 11.015 & 17.837 & MS & 55.612 & 177.630 & 286.055 & 1.558 .704 & 2,7 & 8,5 & 13,8 & 75,0 \\
\hline & & & & MT & 154.372 & 247.535 & 418.526 & 1.683 .920 & 6,2 & 9,9 & 16,7 & 67,2 \\
\hline \multirow{3}{*}{$\begin{array}{l}\text { Taxa crescimento médio } \\
\text { geométrico populacional (\% a.a.) }\end{array}$} & & & & MT e MS & 484.222 & 806.176 & 2.560 .154 & 731.802 & 10,6 & 17,6 & 55,9 & 16,0 \\
\hline & $-0,31$ & 1,45 & 3,54 & MS & 145.207 & 491.481 & 1.304 .914 & 136.399 & 7,0 & 23,7 & 62,8 & 6,6 \\
\hline & & & & MT & 333.583 & 320.127 & 1.255 .240 & 595.403 & 13,3 & 12,8 & 50,1 & 23,8 \\
\hline \multirow{3}{*}{$\begin{array}{l}\text { Proporção da população em } \\
\text { situação urbana de domiclilo (\%) }\end{array}$} & & & & MT e MS & 430.406 & 507.728 & 854.348 & 2.789 .872 & 9,4 & 11,1 & 18,6 & 60,9 \\
\hline & 53,8 & 68,2 & 80,0 & MS & 129.393 & 228.214 & 281.765 & 1.438 .629 & 6,2 & 11,0 & 13,6 & 69,2 \\
\hline & & & & MT & 301.013 & 279.514 & 572.583 & 1.351 .243 & 12,0 & 11,2 & 22,9 & 54,0 \\
\hline \multirow{3}{*}{ PIB per capita (R\$) } & & & & MT e MS & 731.751 & 942.765 & 1.818 .501 & 1.089 .337 & 16,0 & 20,6 & 39,7 & 23,8 \\
\hline & 3.563 & 4.588 & 6.601 & MS & 214.134 & 195.115 & 1.350 .753 & 317.999 & 10,3 & 9,4 & 65,0 & 15,3 \\
\hline & & & & MT & 517.617 & 747.650 & 467.748 & 771.338 & 20,7 & 29,9 & 18,7 & 30,8 \\
\hline \multirow{3}{*}{ Taxa de desemprego (\%) } & & & & MT e MS & 487.259 & 753.020 & 768.491 & 2.573 .584 & 10,6 & 16,4 & 16,8 & 56,2 \\
\hline & 3,42 & 4,69 & 6,22 & MS & 124.591 & 165.188 & 360.194 & 1.428 .028 & 6,0 & 7,9 & 17,3 & 68,7 \\
\hline & & & & MT & 362.668 & 587.832 & 408.297 & 1.145 .556 & 14,5 & 23,5 & 16,3 & 45,7 \\
\hline \multirow{3}{*}{ Renda média familiar mensal ( $R \$$ ) } & & & & MT E MS & 406.598 & 553.150 & 1.246 .723 & 2.375 .883 & 8,9 & 12,1 & 27,2 & 51,8 \\
\hline & 629 & 751 & 963 & MS & 222.561 & 231.187 & 574.743 & 1.049 .510 & 10,7 & 11,1 & 27,7 & 50,5 \\
\hline & & & & MT & 184.037 & 321.963 & 671.980 & 1.326 .373 & 7,3 & 12,9 & 26,8 & 53,0 \\
\hline \multirow{3}{*}{$\begin{array}{l}\text { Proporção da população de } 10 \\
\text { anos ou mais de idade sem } \\
\text { instrução ou com menos de } 4 \text { anos } \\
\text { de estudo (\%) }\end{array}$} & & & & MT e MS & 2.800 .425 & 819.068 & 523.288 & 439.573 & 61,1 & 17,9 & 11,4 & 9,6 \\
\hline & 27,2 & 29,7 & 32,8 & MS & 1.256 .538 & 394.995 & 244.763 & 181.705 & 60,5 & 19,0 & 11,8 & 8,7 \\
\hline & & & & MT & 1.543 .887 & 424.073 & 278.525 & 257.868 & 61,6 & 16,9 & 11,1 & 10,3 \\
\hline \multirow{3}{*}{$\begin{array}{l}\text { Proporção da população em } \\
\text { domiclios com mais de } 6 \text { pessoas } \\
\text { (\%) }\end{array}$} & & & & MT e MS & 1.503 .365 & 1.698 .080 & 749.105 & 631.804 & 32,8 & 37,1 & 16,3 & 13,8 \\
\hline & 13,6 & 18,6 & 24,7 & MS & 1.122 .627 & 471.754 & 259.894 & 223.726 & 54,0 & 22,7 & 12,5 & 10,8 \\
\hline & & & & MT & 380.738 & 1.226 .326 & 489.211 & 408.078 & 15,2 & 49,0 & 19,5 & 16,3 \\
\hline \multirow{3}{*}{$\begin{array}{l}\text { Proporção da população em } \\
\text { domiclios com mais de } 3 \text { pessoas } \\
\text { por dormitório (\%) }\end{array}$} & & & & MT e MS & 572.042 & 1.692 .979 & 1.331 .091 & 986.242 & 12,5 & 36,9 & 29,0 & 21,5 \\
\hline & 9,1 & 11,5 & 16,2 & MS & 260.933 & 1.138 .377 & 332.178 & 346.513 & 12,6 & 54,8 & 16,0 & 16,7 \\
\hline & & & & MT & 311.109 & 554.602 & 998.913 & 639.729 & 12,4 & 22,1 & 39,9 & 25,5 \\
\hline \multirow{3}{*}{$\begin{array}{l}\text { Proporção da população moradora } \\
\text { em domiclilios sem banheiro (\%) }\end{array}$} & & & & MT e MS & 2.363 .517 & 1.011 .168 & 725.177 & 482.492 & 51,6 & 22,1 & 15,8 & 10,5 \\
\hline & 11,6 & 21,9 & 35,8 & MS & 1.272 .859 & 579.416 & 150.573 & 75.153 & 61,3 & 27,9 & 7,2 & 3,6 \\
\hline & & & & MT & 1.090 .658 & 431.752 & 574.604 & 407.339 & 43,6 & 17,2 & 22,9 & 16,3 \\
\hline \multirow{3}{*}{$\begin{array}{l}\text { Proporção da população não } \\
\text { natural da UF (\%) }\end{array}$} & & & & MT e MS & 826.798 & 2.348 .782 & 625.173 & 781.601 & 18,0 & 51,3 & 13,6 & 17,1 \\
\hline & 25,6 & 40,7 & 55,1 & MS & 536.905 & 1.277 .152 & 225.681 & 38.263 & 25,8 & 61,5 & 10,9 & 1,8 \\
\hline & & & & MT & 289.893 & 1.071 .630 & 399.492 & 743.338 & 11,6 & 42,8 & 16,0 & 29,7 \\
\hline \multirow{3}{*}{$\begin{array}{l}\text { Proporção da população não } \\
\text { natural da UF, imigrante nos últimos } \\
10 \text { anos (\%) }\end{array}$} & & & & MT e MS & 707.165 & 2.198 .648 & 1.012 .089 & 664.452 & 15,4 & 48,0 & 22,1 & 14,5 \\
\hline & 6,0 & 10,1 & 17,7 & MS & 434.347 & 1.275 .799 & 312.733 & 55.122 & 20,9 & 61,4 & 15,0 & 2,7 \\
\hline & & & & MT & 272.818 & 930.804 & 680.714 & 620.017 & 10,9 & 37,2 & 27,2 & 24,8 \\
\hline \multirow{3}{*}{$\begin{array}{l}\text { Cobertura populacional da } \\
\text { estratégia de Atenção Saúde da } \\
\text { Familia (\%) }\end{array}$} & & & & MT e MS & 2.553 .895 & 805.523 & 780.900 & 442.036 & 55,7 & 17,6 & 17,0 & 9,6 \\
\hline & 39,2 & 57,9 & 73,6 & MS & 1.424 .864 & 464.219 & 107.577 & 81.341 & 68,6 & 22,3 & 5,2 & 3,9 \\
\hline & & & & MT & 1.129 .031 & 341.304 & 673.323 & 360.695 & 45,1 & 13,6 & 26,9 & 14,4 \\
\hline \multirow{3}{*}{$\begin{array}{l}\text { Média de consultas médicas } \\
\text { básicas por habitante/ano }\end{array}$} & & & & MT e MS & 811.628 & 1.756 .806 & 1.527.223 & 486.697 & 17,7 & 38,3 & 33,3 & 10,6 \\
\hline & 1,29 & 1,72 & 2,10 & MS & 477.034 & 520.146 & 964.449 & 116.372 & 23,0 & 25,0 & 46,4 & 5,6 \\
\hline & & & & MT & 334.594 & 1.285 .729 & 513.705 & 370.325 & 13,4 & 51,3 & 20,5 & 14,8 \\
\hline
\end{tabular}

Q1 - primeiro quartil, Q2 - segundo quartil, Q3 - terceiro quartil, Q4- quarto quartil 


\subsection{Análise estatística}

\section{Análise de regressão linear univariada}

Para a análise estatística univariada foram consideradas 14 variáveis independentes, conforme mostrado na Tabela 4.15. Em sete variáveis foram demonstradas associações estatísticas com a variável dependente, com significância menor que 20\% (valor de $p<0,2$ ), sendo estas selecionadas para o conjunto de indicadores candidatos a compor o modelo explicativo para as taxas de detecção de hanseníase.

Para a variável "Proporção da população moradora em domicílios com seis ou mais pessoas"; "Proporção da população moradora em domicílios sem banheiro"; "Proporção da população não natural da UF"; "Proporção da população migrante de outras UF nos últimos 10 anos"; "Proporção de cobertura populacional da estratégia de Atenção Saúde da Família"; e, "Média de consultas médicas do SUS nas especialidades básicas por hab./ano" foi encontrada associação direta com a "Taxa de detecção de hanseníase", enquanto a variável "PIB per capita", mostrou associação inversa.

Analisando os coeficientes de regressão linear, pode-se supor que para cada variação de $\mathrm{R} \$ 100,00$ no PIB per capita de um município, espera-se uma diminuição da taxa de detecção de hanseníase da ordem de 0,03 casos/10.000 hab.; para cada variação, em um município, de 1\% na 
proporção da população moradora em domicílios sem banheiro, estima-se um aumento da taxa de detecção de hanseníase de 0,10 casos/10.000 hab.; ou que, para cada variação de 1,0 consulta médica básica/hab./ano na média de produção assistencial do SUS de um município, detecta-se 0,88 casos/10.000 habitantes.

\section{Análise de regressão linear múltipla}

As sete variáveis sociodemográficas selecionadas na análise univariada foram submetidas a controle simultâneo, em uma análise de regressão linear múltipla. O ajuste de um modelo de regressão múltipla resultou na escolha de três variáveis explicativas: "Proporção da população em domicílios com seis ou mais pessoas", "Proporção da população não natural da UF" e "Cobertura populacional da estratégia de Atenção Saúde da Família". Em conjunto, elas representam a explicação para $24,1 \%\left(R^{2}\right)$ da variação da "Taxa de detecção de hanseníase" (Tabela 4.16). O coeficiente de regressão parcial para cada uma delas dentro do modelo foi estatisticamente significante (valor de $p<0,001$ ), indicando que o ajuste foi adequado.

As sete variáveis selecionadas, quando tomadas individualmente, cada uma delas explica uma parte da variação da taxa de detecção de hanseníase. No entanto, quando analisadas as variáveis no processo de ajuste que as controla de modo simultâneo, ficou evidenciado que as três 
variáveis do modelo final têm uma contribuição única mais importante na explicação da taxa de deteç̧ão em comparação com a que é devida às demais.

Nos Mapas 4.3, 4.4 e 4.5 estão representadas as variáveis do modelo ajustado na sua distribuição por município. À inspeção visual, para cada uma das três variáveis explicativas, nota-se no MT uma área mais extensa de municípios classificados nos quintis superiores.

No MS, a área de fronteira internacional, a oeste, parece concentrar municípios em quintis mais elevados da proporção da população em domicílios com seis ou mais pessoas; no MT, municípios do último quintil esboçam um alinhamento com a rodovia BR-163 (Mapa 4.3).

No MS, a fronteira paulista, a leste, insinua concentrar municípios dos quintis superiores, quanto à proporção de população não natural do estado; no MT, uma aglomeração de municípios do último quintil é evidente ao norte (Mapa 4.4).

Municípios enquadrados nos quintis mais altos de cobertura populacional da estratégia de Atenção Saúde da Família aparecem espalhados por todo o MT. No MS, a área central do estado, que contém a região metropolitana de Campo Grande, sugere ajuntar municípios em quintis mais baixos de cobertura (Mapa 4.5). 
Tabela 4.15 - Regressão linear simples com a variável dependente Taxa de detecção média anual de hanseníase

\begin{tabular}{|c|c|c|c|c|}
\hline \multirow{2}{*}{ Variável independente } & \multirow{2}{*}{$\begin{array}{l}\text { Coeficiente de } \\
\text { regressão } \\
\text { linear }\end{array}$} & \multirow{2}{*}{$p$} & \multicolumn{2}{|c|}{ Intervalo de confiança de $95 \%$} \\
\hline & & & Limite inferior & Limite superior \\
\hline Tamanho populacional & $-0,000008$ & 0,391 & $-0,0000263$ & 0,0000103 \\
\hline $\begin{array}{l}\text { Taxa de crescimento médio geométrico } \\
\text { anual da população 1991/2000 }\end{array}$ & 0,1190070 & 0,367 & $-0,1404013$ & 0,3784154 \\
\hline $\begin{array}{l}\text { Proporção da população em situação } \\
\text { urbana de domicílio }\end{array}$ & 0,0383510 & 0,215 & $-0,0224777$ & 0,0991796 \\
\hline PIB per capita & $-0,0002949$ & 0,061 & $-0,0006037$ & 0,000014 \\
\hline $\begin{array}{l}\text { Proporção da população economicamente } \\
\text { ativa não ocupada }\end{array}$ & $-0,2633723$ & 0,395 & $-0,8725561$ & 0,3458115 \\
\hline Rendimento nominal médio mensal familiar & 0,0012035 & 0,322 & $-0,0011849$ & 0,0035919 \\
\hline $\begin{array}{l}\text { Proporção da população sem instrução ou } \\
\text { com menos de } 4 \text { anos de estudo }\end{array}$ & $-0,0982938$ & 0,344 & $-0,3028243$ & 0,1062367 \\
\hline $\begin{array}{l}\text { Proporção da população moradora em } \\
\text { domicílios com } 6 \text { ou mais pessoas }\end{array}$ & 0,2309066 & 0,004 & 0,0759349 & 0,3858783 \\
\hline $\begin{array}{l}\text { Proporção da população moradora em } \\
\text { domicílios com densidade de mais de } 3,0 \\
\text { pessoas por dormitório }\end{array}$ & $-0,0614163$ & 0,498 & $-0,2398602$ & 0,1170276 \\
\hline $\begin{array}{l}\text { Proporção da população moradora em } \\
\text { domicílios sem banheiro }\end{array}$ & 0,1039783 & 0,002 & 0,0401795 & 0,1677771 \\
\hline $\begin{array}{l}\text { Proporção da população não natural da } \\
\text { UF }\end{array}$ & 0,1402615 & $<0,001$ & 0,0808962 & 0,1996267 \\
\hline $\begin{array}{l}\text { Proporção da população imigrante de } \\
\text { outras UF nos últimos } 10 \text { anos }\end{array}$ & 0,1484083 & 0,005 & 0,0446372 & 0,2521793 \\
\hline $\begin{array}{l}\text { Cobertura populacional média da } \\
\text { estratégia de Atenção Saúde da Família }\end{array}$ & 0,1183831 & $<0,001$ & 0,0736192 & 0,1631471 \\
\hline $\begin{array}{l}\text { Média de consultas médicas nas } \\
\text { especialidades básicas por habitante ao } \\
\text { ano }\end{array}$ & 0,8778725 & 0,018 & 0,1546023 & 1,601143 \\
\hline
\end{tabular}

NOTA: Os valores de $p<0,2$ estão assinalados em negrito. 
Tabela 4.16 - Modelo ajustado de estimação dos parâmetros de associação com a variável dependente Taxa de detecção média anual de hanseníase

\begin{tabular}{|lccccc|}
\hline \multicolumn{1}{|c|}{ Variável preditora } & Coeficiente & $\begin{array}{c}\text { Desvio- } \\
\text { padrão }\end{array}$ & $\mathrm{t}$ & $\mathrm{R}>|\mathrm{t}|$ & $\begin{array}{c}\text { Intervalo de confiança } \\
95 \%\end{array}$ \\
\hline $\begin{array}{l}\text { Proporção da população em } \\
\text { domicílios com seis ou mais } \\
\text { pessoas }\end{array}$ & 0,271 & 0,071 & 3,82 & $<0,001$ & 0,$131 ; 0,410$ \\
$\begin{array}{l}\text { Proporção da população não } \\
\text { natural da UF }\end{array}$ & 0,133 & 0,029 & 4,65 & $<0,001$ & 0,$076 ; 0,189$ \\
$\begin{array}{l}\text { Proporção da população } \\
\text { coberta pela estratégia de } \\
\text { Atenção Saúde da Família }\end{array}$ & 0,096 & 0,022 & 4,43 & $<0,001$ & 0,$053 ; 0,138$ \\
\hline \begin{tabular}{l} 
Constante \\
\hline
\end{tabular} & $-6,013$ & 2,155 & $-2,79$ & 0,006 & $-10,263 ;-1,763$ \\
\hline
\end{tabular}

Mapa 4.3 - Proporção da população em domicílios com seis ou mais pessoas, municípios do Mato Grosso e Mato Grosso do Sul - 2000

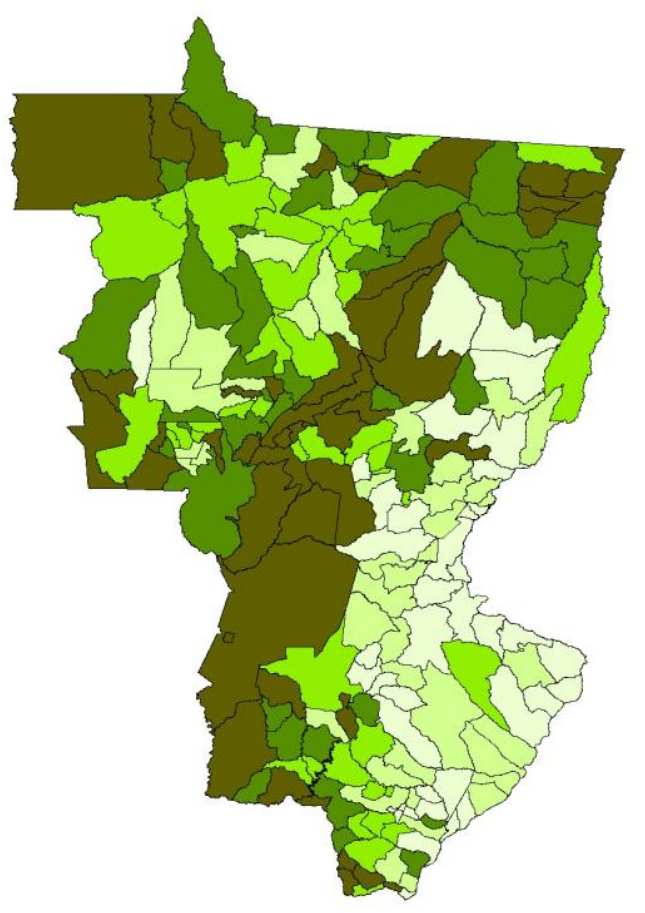

\section{Proporção da pop.}

domicílios 6 ou + pessoas (\%)

Classes em igual frequência
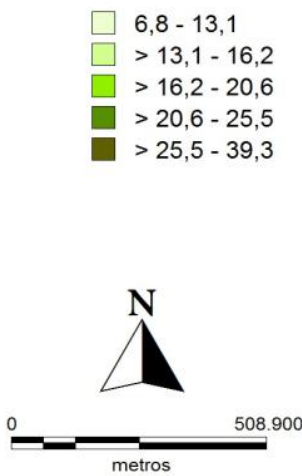

FONTE: Censo demográfico - IBGE 
Mapa 4.4 - Proporção da população não natural da Unidade da Federação - UF, municípios do Mato Grosso e Mato Grosso do Sul - 2000

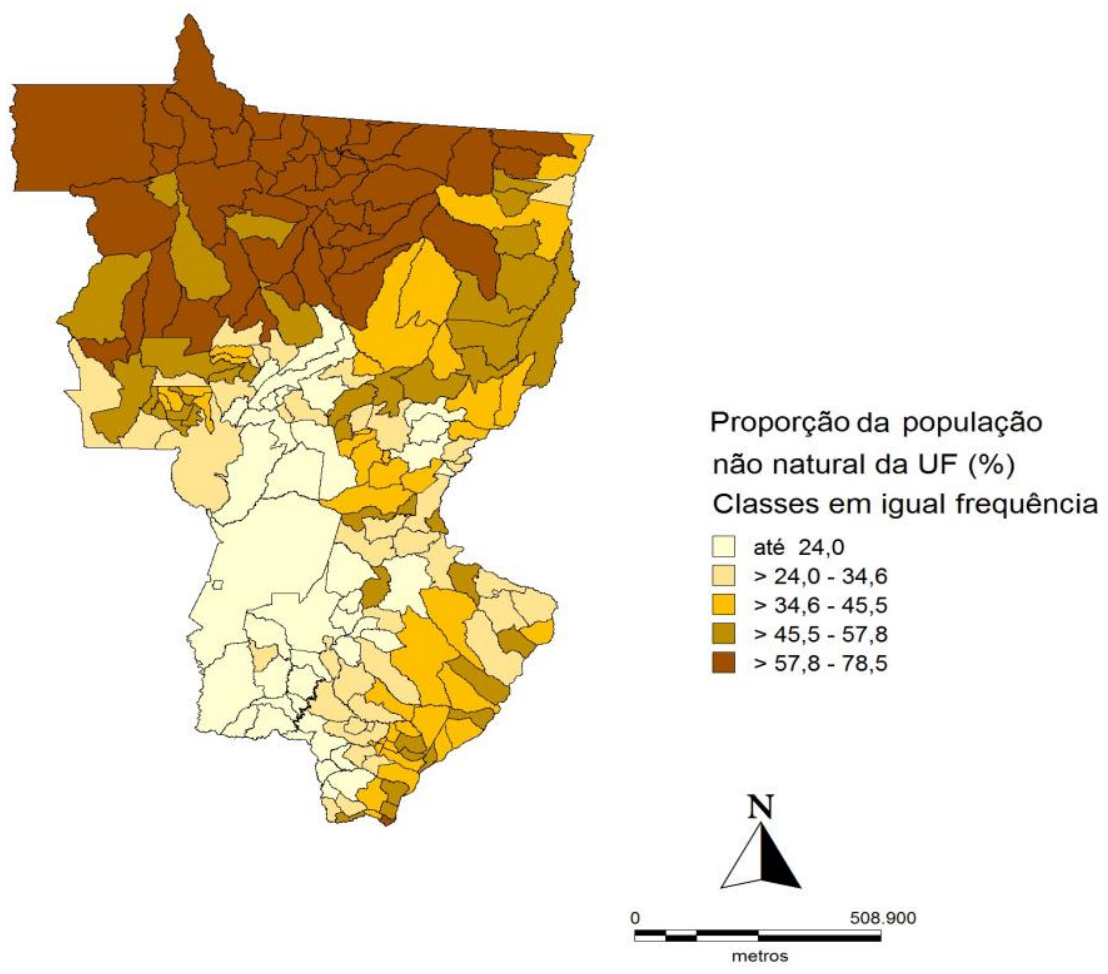

FONTE: Censo demográfico - IBGE

Mapa 4.5 - Cobertura populacional média da estratégia de Atenção Saúde da Família, municípios do Mato Grosso e Mato Grosso do Sul -2000-2006

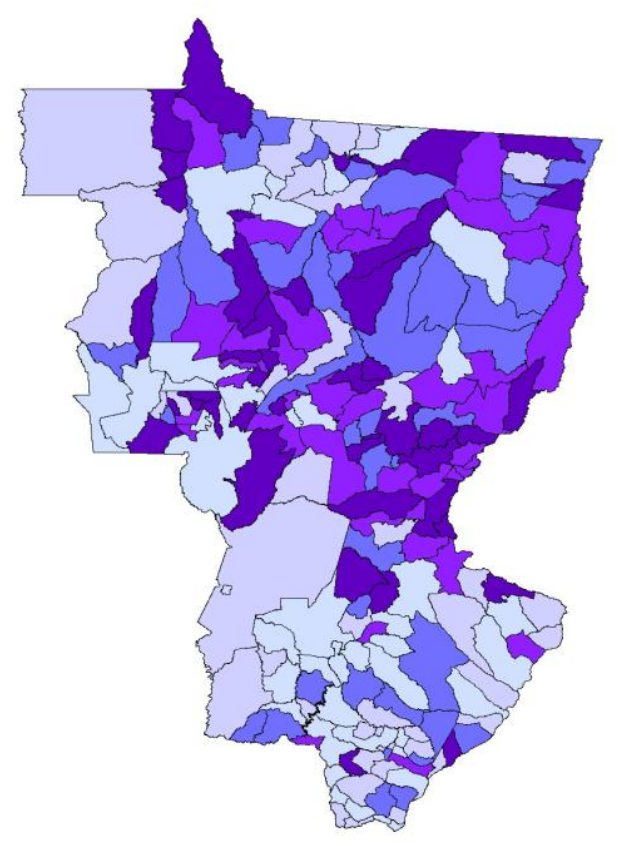

Cobertura pop. Estrat.

Saúde da Família (\%)

Classes em igual frequência
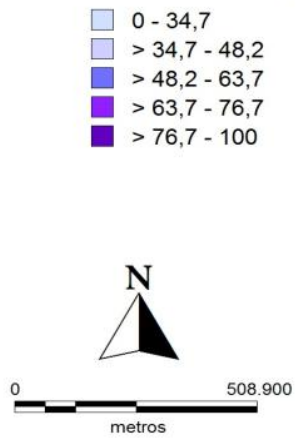

FONTE: Pacto de Atenção Básica 2006, Datasus, SIAB - Ministério da Saúde 
5. Discussão 



\section{Discussão}

Hanseníase foi detectada em residentes de 202 dos 203 municípios estudados, onde três milhões de pessoas estiveram vivendo em áreas de hiperendemicidade. A comparação das taxas de detecção de hanseníase entre o Mato Grosso - MT e Mato Grosso do Sul - MS aponta um contraste, onde o MT apresenta nível hiperendêmico: 12,8 casos / 10.000 habitantes (Tabela 4.2). Este resultado situa-se perto do dobro da média apurada por Magalhães e Rojas (2007) em 2002 para a região Centro-Oeste. Noventa por cento dos municípios hiperendêmicos pertencem ao MT (Anexo).

No Mato Grosso do Sul, a taxa de detecção média anual de hanseníase, no período de 2000 a 2006 esteve em um patamar considerado ainda muito alto de endemicidade: 2,9 casos / 10.000 habitantes. No levantamento de 2001 - 2005 (Tabela 1.1), o resultado deste indicador colocou o MS abaixo da mediana dos estados. Entretanto, conforme salientam Longo e Cunha (2006), o MS carece de estudos sobre a distribuição da hanseníase, que indiquem a real dimensão e a tendência da doença.

Penna et al. (2009) estimaram para o MT, em 2007, a taxa de detecção de 13,2 casos por 10 mil habitantes. Queiroz e Scatena (2009), analisando diferentes períodos entre os anos de 1997 e 2006, encontraram 
um padrão estável para a média das taxas de detecção no MT, entre 11,7 e 13,0 casos por 10 mil habitantes.

Ferreira et al. (2007), em uma série histórica de 1985 a 2004, para o MT, observaram aumento das taxas de detecção de 6,0 para 12,5 casos por 10 mil habitantes. Magalhães et al. (2011) encontraram taxas de detecção no MT, em 2006, acima de 12 casos por 10 mil habitantes, em quase todas as mesorregiões geográficas do estado.

Nas décadas de 1960 e 1970, a hanseníase no Mato Grosso evoluiu com coeficientes de detecção inferiores a 3,0 casos por 10.000 habitantes e durante a década de 1980 mostrou importante aumento, atingindo 10,0 casos por 10.000 habitantes (Brasil, 1998).

É esperado encontrar taxas de incidência de hanseníase mais elevadas entre adultos e idosos, do que em menores de 15 anos de idade, tendo isto sido observado tanto no MT como no MS (Tabela 4.2); o que concorda com os achados de Penna G. et al. (2009) para região amazônica entre 2001 e 2006.

A hanseníase entre menores de 15 anos no MT (Tabela 4.2) mostra níveis hiperendêmicos (acima de um caso por 10 mil habitantes), segundo parâmetros do Ministério da Saúde (Brasil, 2002). No MS, ela poderia ser considerada como estando em um nível alto (de 0,25 a menos que 0,5 caso/10.000 habitantes).

A taxa de detecção em menores de 15 anos dimensiona a intensidade da transmissão da hanseníase. Em consonância com os resultados obtidos, 
em 2003 esta taxa no MT foi encontrada acima da média para a região Centro-Oeste, que foi de 0,8 casos por 10 mil habitantes (Brasil, 2008b). Com valores próximos da cifra média apurada aqui, Ferreira et al. (2007) observaram redução da taxa de detecção entre menores de 15 anos, que passou de 3,8 para 3,0 casos por 10 mil habitantes, entre 1994 e 2004 no MT.

Para $49 \%$ dos municípios da área em estudo, a hanseníase é hiperendêmica entre menores de 15 anos; entre os municípios do MT esta proporção foi de $73 \%$ e no MS foi de $9 \%$ (Anexo).

No MT, Magalhães e Rojas (2007) também encontraram hiperendemia em menores de 15 anos; assim como Queiroz e Scatena (2009), que registraram hiperendemia com elevação desta taxa no período de 1999 a 2007, sendo que este resultado foi interpretado como indicador de agravamento da situação epidemiológica, embora não tenham descartado a interveniência de fatores operacionais na elevação desta taxa, provavelmente devida à expansão da oferta de serviços e melhorias no acesso e na qualidade do diagnóstico.

Hiperendemia ou níveis muito altos de hanseníase entre menores de 15 anos foram também registrados em Recife, por Souza et al. (2001); São Luís do Maranhão, por Figueiredo e Silva (2003); em Paracatu, Minas Gerais, por Ferreira e Alvarez (2005); no estado do Rio de Janeiro, por Pimentel et al. (2004); na região do Vale do Jequitinhonha, em Minas Gerais, por Lana et al. (2007); em Manaus, no Amazonas, por Imbiriba et al. (2009); 
no estado do Piauí por Mastrangelo et al. (2009); e, no estado do Acre por Silveira et al. (2009).

A hiperendemia de hanseníase, levantada em muitos municípios da área em estudo, foi ponto comum com os achados de outros autores; e, ao associar-se a fatores operacionais, sugere "incidência oculta" da doença. Isto sinaliza que parte da transcendência da endemia se deve à falta de acesso ao diagnóstico.

A razão de taxas de detecção entre os estados, maior na faixa etária de menores de 15 anos do que em outros intervalos de idade, a se repetir para paucibacilares e multibacilares e em ambos os sexos (Tabela 4.5), pode estar relacionada a um incremento do risco no domicílio e peridomicílio, na medida em que se eleva a incidência da doença, sendo esta a área esperada de circulação predominante deste grupo etário. Goulart et al. (2006) consideram que poderia existir relação entre a detecção de hanseníase em menores de 15 anos e a distribuição espacial das fontes de exposição, em estudo realizado em Uberlândia, Minas Gerais; sugerindo que estas fontes poderiam estar no ambiente domiciliar ou nas suas proximidades.

A incidência de hanseníase em menores de quinze anos costuma ser menor do que nas faixas etárias mais elevadas, mas, como o comprometimento neural da hanseníase muitas vezes é permanente e pode evoluir mesmo com o tratamento; crianças, quando afetadas pela doença, poderão ter mais tempo de suas vidas oneradas por déficits funcionais e 
deformidades físicas. Oliveira e Romanelli (1998) lembram que a hanseníase pode acentuar desigualdades já existentes no contexto sociocultural e servir de fonte desencadeadora de novos problemas, responsáveis por prejuízos biológicos, sociais, psicológicos e econômicos.

Tanto no MT como no MS, as taxas de detecção de hanseníase no sexo masculino foram maiores que as observadas para o sexo feminino (Tabela 4.2). Perto de 90\% dos municípios apresentaram taxa de detecção no sexo feminino abaixo da observada no sexo masculino. Em um grupo de 19 municípios hiperendêmicos da área em estudo, a taxa de detecção no sexo feminino superou a do sexo masculino (Anexo). Lana et al. (2003), em um município hiperendêmico de Minas Gerais, encontraram uma taxa de detecção maior no sexo feminino, o que consideraram um indicador de possível subdiagnóstico no sexo masculino.

A diferença de incidência para o sexo masculino costuma ser mais marcante em adultos do que em crianças (Feldman e Sturdivant, 1975). No MT esta diferença foi observada e no MS a taxa de detecção em menores de 15 anos do sexo feminino, superou a do sexo masculino desta faixa etária (Tabela 4.2).

No MT houve predomínio de casos paucibacilares sobre multibacilares; e, no MS, esta maioria foi por uma estreita margem, um resultado já esperado, tendo em vista a magnitude da incidência no MT (Tabela 4.3). Resultados semelhantes foram obtidos por Prata et al. (2000), em Aracaju; Cunha et al. (2001), na Bahia; Figueiredo e Silva (2003), em 
São Luís do Maranhão; e, Mastrangelo et al. (2009) no Piauí. Diversamente, maioria de registros da forma multibacilar, tida como sendo mais contagiante que a paucibacilar, foi apontada por Santos e Rabay (1999) em Taubaté; Lana et al. (2000) em Belo Horizonte; e, Lana et al. (2002) em Governador Valadares.

O encontro de casos multibacilares em menores de 15 anos poderia estar refletindo a precocidade da exposição a contatos de risco e a densidade das fontes de contaminação. Nesta faixa etária, dentro de uma série temporal apresentando aumento da taxa de detecção, o crescimento na proporção de casos multibacilares pode significar mais um sinal de agravamento do quadro endêmico; uma advertência para mudança no padrão de transmissão, do contato comunitário ao domiciliar; ou ainda, erro de classificação.

No MT, em menores de 15 anos, a proporção de casos multibacilares foi de $27,1 \%$ e no MS, de $24,4 \%$. Souza et al. (2001) calcularam uma proporção de $28,3 \%$ de hanseníase multibacilar entre menores de 15 anos no Recife, para uma detecção nesta faixa etária de 4,3 casos por 10 mil habitantes, valor acima do encontrado para o MS e o MT (Tabela 4.2).

Em alguns municípios houve predomínio de multibacilares entre os casos diagnosticados em menores de 15 anos, o que pode significar ter havido dificuldades no acesso aos recursos diagnósticos para a clientela mais jovem, deixando "escapar" os casos com uma clínica menos manifesta. 
Manifestações clínicas de casos avançados da forma virchowiana, costumam ser mais evidentes, podendo produzir menor dificuldade na suspeição clínica de hanseníase. A falta de habilidade em classificar a doença na sua apresentação clínica pode conduzir à escolha de um esquema terapêutico, por precaução, o mais prolongado, tal qual é recomendado para multibacilares. Capacitações do pessoal envolvido na atividade diagnóstica podem apurar o processo de classificação clínica.

Presume-se que em uma situação endêmica, a maioria da população possua resistência natural à hanseníase ou facilmente a adquira, reagindo à infecção (Van Brakel et al., 2000). Um excesso de casos paucibacilares, geralmente está associado a altos níveis de exposição e pode indicar expansão da endemia (Albuquerque et al., 1989).

Casos multibacilares representam a parcela mais susceptível da população e apresentam, em média, períodos de incubação mais longos que os paucibacilares (Irgens, 1985). O predomínio de casos multibacilares está associado a áreas de incidência mais baixa e menor difusão da doença na população (Oliveira e Motta, 1990).

Em Londrina, no Paraná, Barro (2004) observou aumento da proporção da forma clínica tuberculóide, que predominou desde o início da série temporal e foi concomitante à queda da taxa de incidência de hanseníase; este resultado foi interpretado como sendo indicativo de prevalência oculta da doença, pois estes achados são paradoxais com a 
combinação esperada, que seria a queda da incidência ao lado de proporções ascendentes de casos multibacilares.

Segundo Ignotti et al. (2004), é válido utilizar séries históricas por idade, classificação operacional, grau de incapacidade física e número de lesões no momento do diagnóstico para suspeitar de detecção tardia da hanseníase na população; informações que podem contribuir para a delimitação de áreas de risco, pela possibilidade da presença de reservatórios ocultos da doença.

Moreira et al. (2008), no Espírito Santo observaram que ao final de um período de incrementos anuais constantes na taxa de deteç̧ão, a proporção de multibacilares, que era predominante, foi cedendo lugar aos paucibacilares, um resultado analisado como decorrente da consolidação de aperfeiçoamentos adotados no programa de controle, alguns anos antes.

A proporção de paucibacilares variou largamente entre os municípios do MT e MS, mesmo captando a média das diferentes situações epidemiológicas e operacionais do período (Anexo). Vale salientar que os dados obtidos na presente pesquisa estão limitados a uma classificação operacional da forma clínica (paucibacilar e multibacilar); o que não permite avançar em conclusões que exigem um maior refinamento da informação sobre a forma clínica. Do ponto de vista operacional, é desejável descobrir o maior número de casos na forma clínica indeterminada, ditos como sendo "pré-polares", de melhor prognóstico. Contudo, casos da forma clínica indeterminada, cujo encontro em elevada proporção pode revelar uma 
prospecção de casos precoce, são classificados operacionalmente dentro do grupo paucibacilar, que inclui uma das formas de polarização da doença, a forma clínica tuberculóide (Madrid Congress, 1953).

A proporção de casos que apresentavam algum grau de incapacidade funcional ou deformidade física decorrente de hanseníase no momento do diagnóstico, classificada como sendo do grau I ou II de incapacidade física (Brasil, 2002), foi de $16,3 \%$ no MT e $18,2 \%$ no MS (Tabela 4.6). Casos considerados precocemente descobertos (grau 0) devem apresentar, no máximo, sensibilidade diminuída sem perda de sensibilidade protetora e nenhum outro tipo de comprometimento físico - uma meta ideal em hanseníase. No grau I de incapacidade física há perda da sensibilidade protetora de mão, pé ou olho; e, no grau II, além da perda da sensibilidade protetora, deve haver alguma outra complicação como úlcera de pele, garra de dedos, pé caído, reabsorção de extremidades ou contratura de dedos ou artelhos.

Quando a descoberta ou a informação de casos de hanseníase não se faz oportunamente, a taxa de detecção se distancia da incidência real na população. A capacidade de detecção merece atenção especial do ponto de vista sanitário-assistencial; pois, o reconhecimento precoce da doença contribui para que os danos físicos da hanseníase possam ser mitigados (Ignotti, 2004). No início da década de 1980, quando foi verificada uma tendência de queda dos níveis endêmicos no estado de São Paulo (Opromolla e Laurenti, 2011), mas ainda em patamar de 1,1 casos 
detectados por 10.000 hab.; Trindade et al., (1987) observaram que pelo menos $30 \%$ dos casos apresentavam algum grau de incapacidade ao diagnóstico, indicando que este grupo, provavelmente, há cinco anos já se encontrava enfermo.

A proporção de casos de hanseníase no MT e no MS, com registro sobre a realização de avaliação de incapacidades ao diagnóstico na categoria "não avaliado" ou "ignorado", foi respectivamente para cada um dos estados, de $12,5 \%$ e 19,9\%. Este indicador pode contribuir para dimensionar a distância que separa os serviços de saúde da integralidade da atenção requerida ao cuidado em hanseníase, contando que a informação, de modo geral, é base para um processo integrativo eficaz das diversas ações assistenciais. Moreira et al. (2008), no Espírito Santo, em 2003, encontraram entre os casos de hanseníase recentemente diagnosticados, a proporção de $12,3 \%$ de não avaliados quanto a incapacidades físicas.

O indicador dado pela proporção de casos com grau II de incapacidade física detectada ao diagnóstico oferece subsídios para avaliar o desempenho dos serviços assistenciais e do sistema de saúde e o impacto do tratamento na transcendência da endemia, contribuindo para a tomada de decisão para aperfeiçoamentos; além de dimensionar a gravidade e o grau de negligência em relação à endemia e insinuar que a incidência pode estar subestimada, dado o caráter crônico-evolutivo da hanseníase. 
Para sustentar a validade da proporção de casos com comprometimento físico severo (grau II) detectado ao diagnóstico como indicador epidemiológico, é recomendável que a parcela de avaliados seja igual ou superior a $75 \%$ (Brasil, 2002), condição não preenchida, ao diagnóstico, por pelo menos um em cada cinco dos municípios estudados. Este resultado sugere observar a necessidade de investimentos para qualificar o trabalho de produção da informação e os processos assistenciais.

Sessenta por cento dos municípios do MS e 90\% dos municípios do MT, tiveram $75 \%$ ou mais dos casos avaliados ao diagnóstico. Destes, cinquenta por cento no MS e $28 \%$ no MT, podem ser classificados em um nível médio ou alto de incapacidades físicas (Brasil, 2002), indicando que poderia, nestes lugares, estar havendo descobertas tardias da doença, com possíveis reflexos na transcendência da endemia; e, ainda, alguma defasagem entre a taxa de detecção e a incidência real da hanseníase. Ao encontro destes resultados, Longo e Cunha (2006) reportam que entre 1994 e 2005 , na capital do MS, mais de $20 \%$ dos casos não tiveram avaliação quanto ao grau de incapacidades ao inicio do tratamento e mais de $30 \%$ iniciaram o tratamento já apresentando incapacidades físicas, chamando atenção para a importância da eficácia das ações dos serviços de saúde nos diversos níveis, no que se refere ao diagnóstico precoce da doença e acrescentando que a maior frequência de incapacidade física ao início do tratamento identificada no grupo do sexo masculino, aponta para a 
necessidade de valorizar as particularidades sociais atinentes a cada grupo no planejamento das ações de controle.

A opção de limitar o estudo na comparação de áreas restringiu a descrição a um período único, não permitindo obter uma visão evolutiva dos indicadores, mas apenas da situação medida em um corte transversal no tempo. Séries históricas de casos podem oferecer mais consistência às avaliações epidemiológicas e operacionais (Hertz-Picciotto, 2008).

Brechas na atividade de detecção de hanseníase poderiam invalidar as conclusões, pela possibilidade de subestimação de casos; e, diferenças acentuadas na capacidade diagnóstica dos municípios sujeitariam a romper a estrutura de comparabilidade entre eles (Reichenheim e Moraes, 1998).

O tratamento da doença, que é oferecido pelos serviços do SUS, quando realizado no próprio município de residência, pode ser um indicativo das possibilidades de acesso ao diagnóstico (Barreto, 2011).

$\mathrm{Na}$ área em estudo, em 2001, a proporção de municípios com casos diagnosticados entre residentes, que não apontaram atendimento no município era de 14\%; e, em 2006, de 2\% (Brasil, 2011c).

Uma associação entre tamanho populacional do município e acesso ao diagnóstico da hanseníase poderia subsistir, uma vez que municípios menores poderiam dispor de relativamente menos recursos de saúde. No entanto, vale referir que é expressiva a parcela demográfica, em ambos os estados, que reside em municípios de maior tamanho populacional (Tabela 4.14). 
Da análise estatística (Tabelas 4.15 e 4.16) pode-se depreender que a coleção mais simples de variáveis independentes, que melhor explicaria a variabilidade das taxas de detecção de hanseníase é composta por variáveis concernentes ao acesso a recursos diagnósticos - "Cobertura populacional média da estratégia de Atenção Saúde da Família"; aglomeração domiciliar, que indiretamente representa a condição socioeconômica, indicada pela "Proporção de domicílios com seis ou mais pessoas"; e, migração, retratada pela "Proporção da população não natural da UF".

A variável representada pela cobertura populacional da ESF contribuiu para conformar as taxas de detecção de hanseníase, resultado que corrobora a afirmação de que os serviços de atenção primária à saúde desempenham um papel essencial para o controle da doença (OMS, 1995).

Segundo lgnotti et al. (2004), no MT, em 2001, de 122 municípios, somente cinco não possuíam Unidades de Saúde; e, entre aqueles que as dispunham, mais de $90 \%$ contavam com um estabelecimento para no máximo cinco mil habitantes. Queiroz e Scatena (2009) citam que de 1999 a 2007, houve no MT um incremento de $115 \%$ na cobertura do programa de controle da hanseníase das Unidades de Saúde.

Melhora do acesso à atenção primária foi apontada por Penna et al. (2008) como um dos fatores responsáveis pela tendência de aumento da taxa de detecção de hanseníase observada no Brasil de 1980 a 2003. Cunha et al. (2007), em município do Rio de Janeiro, registrou aumento da 
taxa de detecção durante descentralização das ações de controle da hanseníase.

Inflexões observadas ao longo do tempo na organização das práticas de saúde pública têm exercido influência nas estatísticas da hanseníase (Nemes, 1989; Andrade, 2006). No Brasil, a reestruturação do Sistema de Saúde ocorrida nos últimos dois decênios do século $\mathrm{XX}$, foi marcada pela Reforma Sanitária e a promulgação da Constituição de 1988 (Brasil, 2006a), cujas ideias centrais eram de universalização, equidade e integralidade do acesso à saúde (Brasil, 2006a); o que impulsionou a interiorização dos serviços e a descentralização das ações de saúde voltadas para agravos prioritários (Brasil, 1990a; Brasil, 1990b). Muitas destas ações foram implantadas com a intenção de melhorar o diagnóstico e tratamento de doenças endêmicas, antes restritas a serviços especializados, instalados nas grandes e médias cidades do país. Neste período, a Atenção Primária, fundamentada no aspecto preventivo do trabalho em saúde, recebe denominação de Atenção Básica e para ela é almejado um papel orientador do Sistema de Saúde (Brasil, 2009b). A ESF, adotada pelo Ministério da Saúde como modelo estruturante da Atenção Básica (Brasil, 1997), em 1998 passa a incluir a hanseníase no seu elenco de agravos prioritários; e, no ano 2000 a descentralização das ações de controle da doença ganhou normas governamentais que regulamentavam a disposição de incentivos técnicofinanceiros para o nível municipal, objetivando a eliminação da hanseníase como problema de saúde pública (Brasil, 2000). De acordo com relatório 
governamental (Instituto de Pesquisa Social Aplicada, 2008), a ESF, em 2007, atinge a cobertura de $47 \%$ da população brasileira.

A cobertura assistencial da ESF foi mais ampla no MT, situação que pode ter colaborado para o alcance de taxas de detecção de hanseníase mais elevadas neste estado (Tabela 4.13). Os municípios com coberturas mais altas da ESF estão concentrados no MT (Mapa 4.5). A média de consultas médicas básicas do SUS hab./ano mostrou-se associada à "Taxa de detecção de hanseníase" (Tabela 4.15); mas, na análise multivariada, a cobertura da ESF foi mais representativa, enquanto indicadora da dimensão médico-assistencial.

Segundo Raposo (2011), em Aracaju, a implantação do Programa de Controle da Hanseníase na Atenção Básica foi contemporânea à implantação da ESF no município, tendo sido notado que picos de detecção aconteceram nos anos em que houve maior incremento de equipes assistenciais.

De acordo com Meima et al. (2004), tendências em taxas de detecção de casos refletem mais proximamente a evolução da taxa de incidência, se não concorrerem mudanças significativas nos esforços de detecção de casos, no comportamento para notificação ou nos procedimentos e critérios diagnósticos. Ao lado de melhorias nas condições gerais de vida, é imputado à efetividade dos serviços de saúde um importante papel no declínio da endemia de hanseníase. Programas de saúde baseados em racionalidades 
preventivas tenderiam a descobrir mais precocemente um maior número de casos.

Embora representem uma minoria entre aqueles da área em estudo, para os municípios que estão próximos ao limiar de eliminação da endemia, Silva Sobrinho e Mathias (2008) nos lembram que a sensibilidade do serviço de saúde para a detecção da hanseníase pode ficar comprometida devido à redução do aparecimento de casos suspeitos. Starfield (2002) refere que a habilidade profissional na atenção primária é construída fortemente sobre problemas comuns e inespecíficos. Durante a fase de eliminação da endemia são colocados desafios ao Sistema de Saúde comparáveis àqueles enfrentados nas situações sanitárias de maior magnitude; pois, frente a um cenário de baixa incidência da doença, é exigido um refinamento das formas de vigilância. No lado assistencial, pela necessidade de oferecer seguimento clínico adequado e oportuno e reabilitação física para uma massa de sequelados, que se avoluma com o prolongamento da endemia, é imprescindível a integração da Atenção Básica a recursos de maior complexidade e especialização, sem os quais a linha do cuidado em hanseníase não se completa. $O$ acesso amplo ao tratamento precoce reduz a endemicidade, mas um desmantelamento apressado dos recursos em vigilância e controle pode custar um tempo a mais de convívio com a endemia e representar um ônus social que poderia ser evitado.

A transmissão pode não decair, mesmo quando a prevalência e a incidência são baixas (Bryceson, 1981), sendo indicado persistir nas ações 
preventivas durante uma situação epidemiológica de "eliminação" da doença. Lechat (1999) chama atenção para o fato de que a restrição das atividades de detecção aos contatos, como estratégia, negligencia a maioria dos casos de hanseníase, lembrando que contato íntimo e prolongado nem sempre é requerido para a transmissão da doença; e, muitas vezes, não é reconhecida nenhuma fonte de infecção (Godal e Negassi, 1973). No entanto, a utilidade de inquéritos na população geral com o objetivo de descobrir casos suspeitos de hanseníase tem sido questionada. Métodos para a deteç̧ão de casos com envolvimento da comunidade e dos profissionais de saúde, retaguarda de especialistas, apoio laboratorial e ações educativas têm se mostrado, quando em conjunto, mais relevantes para o controle da doença (Jesudasan et al., 1996).

A taxa de incidência de hanseníase mostrou-se associada à "Proporção da população em domicílios com seis ou mais pessoas", um achado biologicamente plausível com o que se concebe sobre o risco de transmissão da doença. Uma interpretação da associação com esta variável agregada, indicadora da aglomeração domiciliar, é que uma parte do efeito ecológico no risco poderia ser atribuída diretamente ao modo como os indivíduos habitam o domicílio em suas relações sociais efetuadas em proximidade física. É reconhecido o caráter promocional da qualidade da moradia sobre a saúde; mas, esta variável também pode ser entendida como marcadora de processos sociodemográficos mais amplos, relacionados a outras contrições sociais e com consequências na esfera 
habitacional (Litvoc et al., 1990). Municípios classificados nos quintis superiores de aglomeração domiciliar chegam a esboçar um corredor, que parece acompanhar a BR163, desde o sul do MS, na divisa com o estado do Paraná, até o norte do MT, no limite com o estado do Pará (Mapa 4.3).

No Centro-Oeste, a interiorização do povoamento é relativamente recente e tem sido concentrada em torno do eixo de penetração pioneiro do território; muitas vezes, adensando uma população que busca ascensão social e acaba se instalando sob uma infraestrutura material precária típica de lugares recém ocupados.

O MT e o MS possuem diferenças marcantes entre seus perfis demográficos. O MS tem uma população menor, maior proporção populacional em situação urbana de domicílio e maior densidade demográfica (Tabela 4.8). O MT guarda uma maior proporção populacional em municípios menores, em relação ao MS; maior proporção da população tanto nos municípios que estão se "esvaziando" demograficamente, como nos que apresentaram maior crescimento populacional; e, maior proporção da população nos municípios do primeiro quartil de urbanização e menor no último quartil (Tabela 4.14).

Nos indicadores econômicos, MS e MT apresentam algumas diferenças. No MS, uma parcela proporcionalmente mais ampla da população vive em municípios com melhor desempenho do PIB per capita. Embora tenha sido observado que o valor médio da renda familiar é superior no MT, há semelhança no padrão de distribuição da população quanto à 
renda familiar. O padrão de distribuição da população quanto à escolaridade também mostra correspondência entre as duas UF, mas a taxa de desemprego foi maior no MS (Tabelas 4.8 e 4.14).

As variáveis de renda familiar e de escolaridade são consideradas indicadores socioeconômicos "clássicos". Aqui elas não estiveram associadas estatisticamente com a "Taxa de deteç̧ão de hanseníase", o mesmo ocorrendo com a variável "Proporção da população em domicílios com mais de três pessoas por dormitório" (Tabela 4.15), esta já consagrada, no seu análogo do nível individual, como representativa de fator de risco para a transmissão. A variável socioeconômica "PIB per capita", embora associada à "Taxa de detecção de hanseníase", não se mostrou relevante para compor o modelo explicativo, quando do controle simultâneo; o mesmo ocorrendo com a variável "Proporção da população sem banheiro", onde os dois estados apresentam certa disparidade, com o MT portando um valor médio superior ao MS e uma concentração da população em quartis de piores condições habitacionais (Tabelas 4.11 e 4.14). Os indicadores sociodemográficos do MS se mostraram, em maioria, mais favoráveis que os do MT.

Andrade et al. (1994), em áreas consideradas como sendo focos de hanseníase, encontraram $46 \%$ dos domicílios de doentes com mais de cinco pessoas, contra $33 \%$ nos domicílios vizinhos. Para os autores, as características dos domicílios são indicadoras da situação social e 
econômica dos grupos populacionais, que podem não estar diretamente ligadas ao risco de adoecer de hanseníase.

O padrão de ocupação das moradias reflete o perfil de urbanização e as condições gerais de reprodução social. Para Feldman e Sturdivant (1975), a provisão de moradia em condições salubres está entre os principais fatores do controle da hanseníase. Bryceson (1981) refere que a aglomeração humana está associada ao aumento dos contatos e, por sua vez, com uma maior intensidade de transmissão.

Em uma localidade da Índia, o número de casos de hanseníase por domicílio esteve associado positivamente ao número de habitantes da moradia (Pillai et al.,1984). Em outro estudo, diferenças na incidência da hanseníase entre famílias hindus e muçulmanas, morando sob as mesmas condições socioeconômicas, foram explicadas pelo tamanho médio das famílias (Chaturvedi, 1988).

Carvalheiro (1986), estudando a distribuição de outra enfermidade contagiosa, a doença meningocócica, analisou perfis de classe social e níveis de incidência, aventando que fenômenos migratórios e epidêmicos estiveram ligados ao processo de desenvolvimento da metrópole de São Paulo. O nexo entre a distribuição da doença e a divisão social do território foi estabelecido pelas condições de reprodução de classe social, ao predisporem à aglomeração e renovação de susceptíveis.

Gouveia (1999), alerta para o fato de que, no Brasil, o crescimento urbano desorganizado raramente tem sido acompanhado de investimentos 
adequados em infraestrutura habitacional, resultando no aumento de indivíduos vivendo em condições insalubres, inclusive com grande adensamento de pessoas por cômodo.

A orientação dos recursos públicos para investimentos econômicos, em detrimento dos gastos sociais, é uma faceta da urbanização corporativa que acompanha o atual período de modernização (Santos, 2005). Há especulação como instrumento mercantil de escassez, tanto em relação ao acesso a terra como para a habitação urbana, gerando déficit de moradias e extensão da cidade.

A carência em serviços de infraestrutura urbana alimenta a especulação pela valorização diferencial das diversas frações da cidade, fazendo do confinamento humano nas moradias um dos resultados do "círculo vicioso" decorrente de determinados usos do espaço.

Em muitas partes do mundo, o declínio da hanseníase tem sido associado com melhorias de renda, habitação, instrução e das condições sanitárias do meio, sendo amplamente aceito que a partir da presença de uma fonte humana ou ambiental, a aglomeração pode aumentar o risco de infecção (Noordeen, 1994). Um maior risco de contágio pode estar associado ao confinamento (Fine, 1982), uma situação não rara nas moradias de muitas cidades brasileiras.

Por outro lado, Hegazy et al. (2002) em estudo realizado no Egito, com indivíduos de uma localidade com alta prevalência, não encontraram associação de hanseníase com escolaridade, índices de aglomeração 
domiciliar e de dormitório ou estrato socioeconômico. Em semelhança aos achados destes autores, os resultados não apontaram associação linear da taxa de hanseníase com renda familiar, escolaridade ou ocupação de dormitórios, constituindo um aparentemente paradoxo na relação entre condição socioeconômica e produção da endemia, no nível ecológico. Mas isto pode ser compatível com a natureza coletiva do processo saúdedoença, especialmente em doenças contagiosas, cujas consequências de um contato são dependentes da prevalência da doença na população (Halloran, 2001).

O risco oferecido em se morar sob "pressão de ser exposto", dada pela intensidade da transmissão da hanseníase na comunidade, também é gerado por eventos aos quais fatores socioeconômicos podem estar direta ou indiretamente relacionados. A eficácia de um contato singular em transmitir doença pertence também a exposições que ocorreram em outros indivíduos; o que equivale a dizer que o resultado endêmico se faz condicionado ao contexto societário do grupo, o que pode tornar o tributo individual, tomado a cada um de forma isolada, insuficiente para justificar um quadro epidemiológico. A linearidade esperada da relação entre a presença do fator de exposição individual e doença, que em última instância se dá no indivíduo, está sempre sendo "deformada" pelo modo como um determinado coletivo humano estabelece laços sociais (Koopman e Longini, 1994). Calado et al. (2005) chegaram a índices de infecção pelo M. leprae, 
semelhantes entre o grupo de contatos domiciliares e peridomiciliares do caso índice.

Seria, então, o efeito ecológico, um híbrido. Ele se faria tanto pelas condições sociais e naturais dadas, que interferem na configuração das exposições ao bacilo, quanto pela acolhida recursiva do risco produzido em sociedade, ao criar a necessidade de reproduzir a ela mesma de modo integral (Godelier, 2001), em um movimento que é transpassado para todas as instâncias e relações sociais e que não se estabelece unicamente a partir de atributos individuais ou dos grupos, mas deriva da projeção sobre a sociedade como um todo, do resultado das relações nascidas senão a partir de indivíduos e de grupos. Nestes termos, o condicionamento social de uma endemia poderia ser interpretado enquanto a ultrapassagem de um tempo técnico, a transcender uma realidade posta, seja da perspectiva individual ou de contextos localmente restritos e desvinculados de acontecimentos globais.

Taxa de detecção de hanseníase mostrou associação ecológica com migração. O MT apresentou praticamente 0 dobro da proporção de migrantes, inclusive com relação àqueles de migração nos últimos 10 anos, tomando como base o levantamento censitário de 2000 (Tabelas 4.11 e 4.12). Um aglomerado extenso de municípios que apresentam maior proporção da população não natural da UF aparece ao norte do MT (Mapa 4.4.). 
Quanto à proporção de população urbana, os dois estados não apresentam diferenças extensas, mas a densidade demográfica do MS foi o dobro da observada no MT, indicando que este ainda guarda um potencial de ocupação importante (Tabela 4.8).

Pelo menos $20 \%$ dos municípios tiveram taxas de crescimento demográfico acima de $3,97 \%$ e para outros $20 \%$ este crescimento foi negativo, demonstrando uma dinâmica populacional heterogênea para a área em estudo; que aparenta, à inspeção visual, ser mais acentuada ao centro-norte do MT (Mapa 4.2). Esta área concentra municípios com populações jovens, baixa densidade demográfica, representativa migração recente, volume populacional urbano menos acentuado e com algum excesso demográfico masculino.

Estes traços demográficos podem ter sido condicionados por um rápido crescimento econômico em função da expansão de atividades agropecuárias (Fernández, 2007). Acresce-se que, diferentemente do período anterior, estas atividades tem passado por rápidas mudanças no padrão de organização técnica da produção; e, além disto, no Brasil, tem sido verificada durante a ocupação de lugares novos, a exploração desordenada dos recursos naturais (Arruda, 1999; Oliveira et al., 2012), podendo gerar migração após o seu esgotamento. Tais fatores, aparentemente longe das questões epidemiológicas, poderiam estar subjacentes às movimentações populacionais e à intensificação do fluxo de 
produtos primários sobre o território, em compasso com o avanço da fronteira agrícola (Bonelli, 2001; Costa, 2008).

Desigualdades sociais entre áreas geográficas podem desencadear correntes migratórias, sendo que migrações rurais para o meio urbano são comuns em países endêmicos de hanseníase; muitas vezes, elas são interpretadas como sendo um efeito da exclusão social que parte da população rural está exposta ou como resultado da atração exercida pelas oportunidades de obtenção de renda, não encontrada no ambiente rural (Noordeen, 1994).

O povoamento do MT, muito à custa de imigrações de outros estados, continua demonstrando vigor, sendo este um ponto atual de contraste com o MS (Tabelas 4.12 e 4.14).

Peiter (2005) considera que a hanseníase acompanhou as áreas de maior afluxo migratório da faixa de fronteira internacional situada a oeste do Brasil, formando um arco que vai desde o oeste do Acre até o norte do Mato Grosso do Sul.

Queiroz e Scatena (2009) salientam o achado de tendência ascendente do coeficiente de detecção de hanseníase principalmente na região Norte do $\mathrm{MT}$, que teve acentuado crescimento demográfico na década de 1990; o que concluem esteja relacionado à ocupação do espaço, provavelmente em correspondência à expansão da fronteira agrícola: a análise temporal e espacial do coeficiente de detecção evidenciou um movimento de expansão da doença para o norte e noroeste do estado. 
Magalhães et al. (2011) localizam a fase mais proeminente das migrações no MT entre as décadas de 1970 e 1990, coincidindo com o período de crescimento exponencial da taxa de detecção de hanseníase. De 1940 a 1996, a proporção urbana da população, que era de $20 \%$, saltou para $80 \%$; tendo sido notado uma interiorização da doença a partir de 1999 , atingindo pequenas cidades e o surgimento de focos da doença, concentrados na parte norte do estado, onde se localizam municípios que depois de 1990 se tornaram fortemente atrativos de migrantes.

Ao mesmo tempo em que o território tem mudada a sua funcionalidade, podem ser instaladas as premissas naturais para a propagação da endemia de hanseníase. Quando isto acontece, imprime-se a ideia de que a distribuição da doença encontra-se subordinada ao espaço usado. Barreto et al. (2011), acentuam que a hanseníase, com um período de incubação relativamente longo, teria a sua distribuição espacial relacionada aos níveis de transmissão históricos e a determinantes epidemiológicos, tal como o padrão migratório. Para os autores, as mudanças econômicas que ocorreram nos últimos 30 anos colocaram o Brasil em uma posição de destaque no cenário mundial. Mas, elas foram acompanhadas de graves problemas ambientais, tais como os relacionados ao volume de desmatamento para expansão de atividades agroindustriais e à extração de produtos básicos e matérias primas de exportação; e, ainda, mobilizaram grandes contingentes demográficos, expandindo áreas de 
transmissão de doenças endêmicas como a hanseníase, anteriormente mais comuns em áreas rurais.

Fluxos migratórios modificam a composição da população quanto à experiência de contato com o M. leprae. Kerr-Pontes et al. (2004) afirmam que um afluxo migratório rural-urbano contribuiu fortemente ao crescimento de algumas cidades do Ceará, onde a introdução de susceptíveis deve ter influenciado a difusão da hanseníase; assim como, no passado, o estabelecimento de focos da doença deve ter sido propiciado pela ampliação da malha ferroviária, outrora largamente utilizada para transporte de passageiros.

Os estados da região Sul (Paraná, Santa Catarina e Rio Grande do Sul) e o estado de São Paulo, na região Sudeste, têm apresentado as menores taxas de detecção de hanseníase do país; e, destes lugares, têm sido originária uma expressiva parcela da população não natural do Mato Grosso e Mato Grosso do Sul.

De acordo com o IBGE (2008), na população do MT, no ano 2000, havia $20,5 \%$ de sulistas e paulistas; e, no MS, 17,6\%. Migrações de áreas indenes poderiam contribuir ao processo de reposição de susceptíveis à infecção pela sua suposta condição de escasso contato anterior com o $M$. leprae.

Mas as migrações, também poderiam, em um passado próximo, terem contribuído para disseminar focos de hanseníase ou recrudescer aqueles existentes, introduzindo infectantes. O fluxo migratório à região 
amazônica foi acentuado desde o final da década de 1970, quando a hanseníase apresentava alta endemicidade na região Sudeste (Silva et al., 2010) e no estado do Paraná.

\subsection{Hipóteses sobre o processo endêmico da hanseníase}

As relações entre o $M$. leprae e o hospedeiro humano e o processo de transmissão da hanseníase ainda permanecem não completamente esclarecidos. Há evidência de que a taxa de infecção excede a de doença (Calado et al., 2005), sendo plausível supor que possam existir outras fontes de infecção, além de indivíduos doentes, não tratados (Deps, 2001). O bacilo de Hansen é um microrganismo de baixa patogenicidade e alta infectividade (Scollard et al., 2006) e o período de transmissibilidade da hanseníase pode iniciar antes dos primeiros sintomas (Sampaio e Rivitti, 2000). O achado de infecção generalizada entre tatus selvagens revelou a existência de reservatórios alternativos do bacilo (Truman et al. 2011).

Correntes migratórias podem estar condicionando a delimitação de espaços endêmicos de hanseníase, hipótese que tem como fundamento biológico a possibilidade de estar havendo reposição de susceptíveis ou contagiantes neste processo. Neste caso, seria esperada uma incidência 
desproporcional da doença sobre imigrantes ou uma proporção de infectados, previamente, em grande número entre estes, se a doença fosse endêmica em seus lugares de origem.

No Brasil, outras doenças infecciosas, tal como a Doença de Chagas (Goldbaum, 1976), experimentaram expansão de seu espaço endêmico focal, paralelamente a mudanças no modelo de desenvolvimento econômico, quando a estrutura agrária e o padrão de ocupação do solo resultante favoreceram movimentos migratórios. A grandeza e persistência destas correntes de deslocamento humano acabaram contribuindo, enquanto premissas espaciais, para a extensão do ciclo da doença aos ambientes urbanos, na medida em que estes espaços passaram a ser ocupados pelo contingente demográfico rural, excluído de processos produtivos modernizados, exigentes de grandes investimentos de capital.

$\mathrm{Na}$ área em estudo, a hanseníase não tem sido documentada como de incidência desproporcional entre imigrantes. As migrações poderiam influenciar o processo endêmico por outras vias e a hipótese gerada aqui é a de que os fenômenos migratórios exerceriam papel intermediário ou condicionador da expansão da endemia, ao movimentar-se uma massa de indivíduos que se torna apta a transmitir a infecção dentro das populações de destino. A transmissibilidade da hanseníase pode expressar-se independente do potencial patogênico, cabendo distinção entre "hanseníaseinfecção", restrita à porta de entrada nasal e "hanseníase-doença", como forma patogênica generalizada (Rotberg e Bechelli, 1950). Abreu et al. 
(2006) questionam se haveriam diferenças no padrão local de defesa da mucosa oral, que pode estar histologicamente comprometida mesmo sem lesões evidentes, em relação às respostas imunológicas sistêmicas contra o M. leprae.

Young et al. (2004), em estudo onde mapearam o material genético de amostras de $M$. leprae obtidas de pacientes, verificaram um padrão sequencial de DNA sugestivo de que a incidência contínua da hanseníase na comunidade foi o resultado de uma complexa série de eventos de transmissão, em vez de um surto causado pela transmissão recente de um ou mais clones dominantes estáveis.

Hatta et al. (1995) testaram a presença de M. leprae em cavidade nasal por meio de reação específica em cadeia da polimerase - PCR e concluíram que a positividade da PCR na população geral foi extensa, mas não foi persistente ao longo de dois anos, indicando que a contaminação nasal pelo bacilo é transitória. A positividade para a PCR foi demonstrada não possuir valor preditivo para o aparecimento de doença e ocorreu com dependência temporal, mas não necessariamente relacionada com a presença de pacientes. Positividade para PCR, que indica contaminação, não teve relação com soropositividade para anticorpos anti-glicolipídio fenólico I - anti-PGL I, que pode ser considerada uma expressão de infecção e da carga bacilar (Foss et al., 1993); mas a ausência de conversão sorológica entre os indivíduos PCR positivos / anti-PGL I negativos, fez os 
autores aventarem a hipótese de que este anticorpo seria produzido somente após contatos múltiplos, dependentes de sua intensidade.

Presença de $M$. leprae em amostras de muco nasal pode ser comum em populações nas quais a hanseníase é endêmica, não obstante possa haver falso-positivos; e, contaminação nasal pode não implicar, necessariamente, em infecção ou excreção de bacilos. Entretanto, a colonização da superfície da mucosa respiratória poderia favorecer o espalhamento da exposição (Hatta et al., 1995).

A susceptibilidade à hanseníase vista em uma escala poderia ser representada em três blocos; no primeiro, próximo ao grau máximo de resistência, presumidamente estaria a maior parte da população; seguida por indivíduos imunitariamente abertos a infecções localizadas; e, no seu mínimo, estariam aqueles que, uma vez infectados, teriam chances de desenvolver a doença e eliminar bacilos no ambiente, de forma contínua e relativamente em grandes quantidades.

Nesta hipótese, o papel de "transferir" o bacilo de um hospedeiro a outro poderia ter a cooperação de portadores transitórios do $M$. leprae, tal como "reservatórios secundários" ou "vetores biológicos", ao unirem os doentes de um foco primário a outros susceptíveis distantes do foco de origem, mesmo sem necessariamente estarem ou virem a se tornar doentes, função que poderia ser fomentada no nível populacional pelas migrações.

Hegazy et al. (2002) encontrou que indivíduos com idade acima de 40 anos são quatro vezes mais propensos para desenvolver hanseníase, 
resultado que considerou sugestivo de que o desenvolvimento de doença clínica em hanseníase requer um longo período de incubação e um complexo sistema de interações patógeno-hospedeiro.

Bakker et al. (2006), pesquisando anticorpos anti-M. leprae em amostras de sangue pelo método de imunoabsorção por ligação enzimática ELISA, verificaram que não somente contatos domiciliares de pacientes de hanseníase soropositivos tiveram maior soropositividade para o teste, mas que os moradores das vizinhanças destes pacientes também.

Opromolla et al. (2006) relatam concentração de casos de hanseníase ao norte e oeste do estado de São Paulo entre 1991 e 2002. Este achado foi relacionado ao recrudescimento recente da ocorrência da hanseníase na contígua região Centro-Oeste. Na propagação da hanseníase foi aventado o papel exercido pelas migrações, associado ao processo de interiorização do desenvolvimento econômico e a influência da combinação entre a saturação de suscetíveis e as diversas estratégias de controle adotadas no estado de São Paulo.

Em hanseníase, o processo de transmissão vem sendo amplamente investigado pelas variáveis de intensidade e duração da exposição: contatos diretos, fechados, prolongados e com fontes multibacilares parecem oferecer maior risco do que não contatos, contatos indiretos, abertos, eventuais e com fontes paucibacilares. A diferenciação espacial da hanseníase resultaria do acúmulo histórico dos riscos de adoecimento, quando fatores que 
interferem na exposição ao $M$. leprae, conjugam-se aos modos com que se distribuem, em cada época, os reservatórios e susceptíveis à doença.

A maioria da população possui ou facilmente adquire resistência ao adoecimento por hanseníase, mas alguma parcela poderia continuar susceptível à infecção de mucosa nasal (Cree e Smith, 1998). Contatos resistentes a desenvolver doença, mas não para protegerem-se de infecções localizadas, poderiam se tornar portadores assintomáticos (Klatser et al., 1993; Izumi et. al., 1999), sujeitos a reinfecções de porta de entrada (Smith et al., 2004), quando a proteção específica é temporária.

Uma evidência da eficácia dos mecanismos de transmissão em hanseníase é dada pela sua distribuição universal, suportando, o M. leprae, uma larga variação das condições externas (Desikan e Sreevatsa, 1995). A extensa distribuição da infecção na população de lugares com relativamente poucos casos bacilíferos e os achados que apontam para uma maioria de casos de hanseníase sem história de contato (Joseph et al., 1985), trazem questionamentos sobre a existência de reservatórios não humanos, a natureza da exposição e os modelos de resposta do hospedeiro (Smith et al., 2004).

Embora a doença tenda a manifestar-se de forma endêmica, situações epidêmicas também têm sido descritas. Na Nova Guiné, 15\% da população adoeceram em um período de 15 anos. Na Nigéria, a prevalência chegou a atingir $17 \%$ do contingente demográfico. Na llha de Nauru, no Oceano Pacífico, no início do século XX, uma epidemia de hanseníase 
afetou $24 \%$ da população em menos de cinco anos (Margarido-Marchese et al., 1996).

Penna M. (1988) levantou uma hipótese para a tuberculose, outra micobacteriose contagiosa com reservatório humano, de que os mecanismos desenvolvidos pelo hospedeiro para resistir ao adoecimento seriam mais relevantes para limitar a disseminação da tuberculose do que as condições de transmissão; esta autora cita Bradley (1972), que formulou modelos de interação ecológica enfocando o problema da limitação das populações de parasitas na natureza. Os mecanismos de regulação do limite superior de parasitas seriam dados pelas condições de transmissão (tipo I); pela diminuição de hospedeiros efetivos ou não imunes, que ao atingirem um número crítico, comprometeriam a perpetuação do agente na natureza (tipo II); e, pelo hospedeiro individual (tipo III), onde o modo como ele resiste à infecção permitiria a continuidade do agente na natureza.

No caso em que a condição de transmissão é o mecanismo regulador preponderante (tipo I), um número múltiplo de parasitas é sempre esperado de uma inoculação inicial e a população de parasitas seria regulada por modificações no ambiente de transmissão.

Na hipótese da população de hospedeiros regular a de parasitas (tipo II), a infecção resultaria na eliminação de hospedeiros ou parasitas, podendo redundar no aparecimento de indivíduos imunes, nos quais os mecanismos imunológicos determinariam resistência completa à reinfecção, levando à diminuição da quantidade de hospedeiros parasitáveis. Um número mínimo 
de susceptíveis seria requerido para manter a circulação do parasita na natureza.

Em hanseníase, os mecanismos de regulação do limite superior de bacilos na natureza parecem estar mais próximos do modelo do tipo III de Bradley. O esgotamento de susceptíveis seria evitado por meio de uma resposta imunológica que não eliminaria a possibilidade de reinfecções nasais, com algum grau de contagiosidade. Ao mesmo tempo, esta resposta imune ajudaria a superar a dispersão espacial dos susceptíveis à doença e a resistência à infecção pelo $M$. leprae presente na população.

Em sua ecologia, o bacilo poderia suplantar a regulação imposta pelo esgotamento de hospedeiros susceptíveis por diversas vias. $O M$. leprae pode permanecer viável fora do organismo ou infectar animais inferiores e se manter no ambiente; o hospedeiro pode se tornar infeccioso de modo contínuo ou intermitente (Smith et al., 2004) e o bacilo circular na população, mesmo com escasso número de doentes (Beyene et al., 2003).

Alguns autores têm registrado que a resistência à infecção de porta de entrada em hanseníase é transitória, enquanto dura a infecção localizada na mucosa nasal, podendo inclusive reincidir (Ramaprasad et al., 1997). Em lugares endêmicos, esta característica da infecção poderia contribuir para manter uma descarga cíclica de bacilos no ambiente. A prevalência da infecção nasal por $M$. leprae pode ser extensa, ultrapassando em muito a da doença (Klatser et al.,1993; Hatta et al., 1995). 
A capacidade de sobrevivência para um microrganismo em trânsito, entre a fonte de contaminação e o hospedeiro, é uma exigência primordial para que haja parasitismo. O tempo de sobrevivência do $M$. leprae dessecado, fora do organismo humano, pode ser longo, tanto quanto de dois a cinco meses, especialmente em ambientes úmidos (Desikan e Sreevatsa, 1995). Este período é próximo ao de proteção conferida pela resposta humoral específica local, que aparece cerca de duas semanas após estímulo antigênico bacteriano sobre mucosas, podendo durar meses e ainda guardar memória imunológica (Bellanti, 1980).

O contato inicial de um indivíduo com o agente infeccioso geralmente ocorre por meio dos epitélios, sendo a mucosa do trato respiratório uma das vias de entrada mais comuns, especialmente a do nariz, uma das maiores fontes de estimulação natural do sistema imunológico (Esquenazi, 2007). O tropismo pelas células do hospedeiro situadas na mucosa do nariz poderia resultar devido à disponibilidade de sítios receptores de superfície, essenciais para a sobrevivência do bacilo; e, ainda, pela dificuldade de acesso das células de defesa, ao epitélio de transição com o meio externo.

A resposta imunológica específica à infecção generalizada pode não corresponder à proteção contra a proliferação local do M. leprae. Em estudo realizado em local endêmico, vacinação BCG não esteve associada à presença ou ausência de DNA de $M$. leprae na cavidade nasal de indivíduos sadios (Beyene et al., 2003). Isto sugere que um estímulo à imunidade 
específica celular, embora para outra micobactéria, talvez não interfira na proteção contra a infecção local pelo bacilo de Hansen.

É suposto que de um encontro primário com um antígeno depositado em mucosas, haveria estímulo para a produção de Imunoglobulina $A-\lg A$ pelas células efetuadoras do ramo humoral da imunidade, representadas por plasmócitos localizados nos tecidos linfóides que revestem o trato respiratório, gastrintestinal e geniturinário. Nas secreções respiratórias as IgA se juntam em um dímero com outra molécula protéica, o componente secretor, impedindo que o complexo formado seja degradado por enzimas proteolíticas, presentes em abundância na superfície da mucosa (Bernier, 1980).

A proteção conferida pela resposta específica humoral de mucosa, mesmo sendo de curta duração, parece constituir a "primeira linha de defesa do organismo" (Cree e Smith, 1998), pois a IgA possui estrutura molecular que adquire estabilidade nas superfícies corporais e é capaz de atravessar os tecidos, concentrar-se em torno do sítio de contaminação e inibir a multiplicação do agente infeccioso.

Durante uma segunda exposição ao antígeno, se a dose de imunógeno for suficiente para permitir que algum material permaneça para estimular o sistema imune, após a formação de complexos é iniciada uma resposta secundária anamnésica típica: mais intensa, precoce e duradoura que a advinda do primeiro estímulo. Mas, se a dose de imunógeno for muito pequena, pode não ocorrer uma resposta imune aumentada, possivelmente 
porque todo o imunógeno em contato é consumido durante a formação de complexos antígenos-anticorpo, que depois são fagocitados e removidos; o que pode privar as células formadoras de anticorpos de um estímulo imunogênico (Herscowitz, 1980).

Não está descartada, portanto, a possibilidade de repetidas infecções de mucosa nasal induzirem tolerância imunológica (Naafs, 2001). A tolerância imunológica possui especificidade e em linfócitos B produtores de imunoglobulinas a indução é mais rápida e a duração mais curta (cerca de 40 dias) do que a observada para linfócitos $T$, efetuadores da imunidade celular; sendo ainda mais fácil de ser induzida naqueles que não possuem células de memória de um estímulo primário, cuja formação depende da dose de exposição ao antígeno (Bellanti, 1980); o que sugere ser especialmente vulnerável, a população oriunda de áreas onde não ocorre transmissão do M. leprae.

Um modelo epidemiológico para representar a dinâmica da doença na população deve considerar que a resposta imunológica ao $M$. leprae não se mostra obediente a padrões estáticos. Segundo Esquenazi (2007), a saturação de estímulos antigênicos por infecções crônicas ou recorrentes pelo $M$. leprae pode induzir a hiporresponsividade, assim como, após o tratamento da hanseníase, pode se seguir reconstituição imunológica. A regulação da resposta imune mediante estímulos persistentes, bem como mecanismos e mediadores envolvidos na indução de estados de hiporresponsividade, anergia ou tolerância imunológica, estão relacionados 
à falha na efetuação da resposta imune celular, sugerindo uma forte modulação negativa desencadeada pelo patógeno; mas, pode haver reversão destas condições, decorrente de alteração no status clínico do paciente, com ativação de linfócitos timodependentes e produção de citocinas inflamatórias.

Admitindo que o mecanismo de transmissão do $M$. leprae é eficaz, a regulação da população de bacilos na natureza poderia estar sendo modulada por fenômenos imunológicos de resistência ao crescimento do agente infeccioso na porta de entrada nasal, cuja eficácia dependeria da dinâmica da infecção e da doença no coletivo humano.

Estando devassáveis as barreiras de defesa do hospedeiro, a interação com o agente infeccioso pode resultar na sua invasão; sendo que contra isto, a periferia do sistema imune, principalmente no nível das mucosas, desempenha papel preventivo importante (Madkan et al., 2006). No susceptível à hanseníase, há deficiência na imunidade celular, podendo a imunidade humoral encontrar-se plena. Para que a interação do hospedeiro com o $M$. leprae resulte em infecção generalizada é necessário romper a linha de defesa representada pelos mecanismos imunológicos inatos e adaptativos de ação localizada. Os indivíduos infectados pelo $M$. leprae poderiam transmitir o bacilo e sensibilizar a população de contato em exposições de baixa dose, pois a multiplicação bacilar é lenta, em vista do tempo necessário para a montagem de resposta imunológica específica local. 
É aceito que a continuidade do $M$. leprae no ambiente está condicionada à presença de doentes crônicos, portadores de infecções generalizadas. No entanto, no nível populacional, a repetição de infecções agudas e restritas à porta de entrada respiratória, caracterizadas por resposta imunológica incompleta, proteção transitória e potencial infectivo temporário poderiam subsistir em interdependência à presença de bacilíferos crônicos. Algumas propriedades antigênicas do bacilo podem suprimir a interação celular do hospedeiro voltada a sua destruição; o PGL-1 presente na parede bacteriana, pode exibir atividade imunossupressora sobre as células dendríticas do ramo periférico do sistema imune e inibir a resposta primária à presença do $M$. leprae (Scollard, 2006). A repetição de infecções transitórias na população, embora pudesse desencadear hiporresponsividade imunológica apenas em alguns indivíduos, poderia ser suficiente para propagar ciclicamente a infecção pelo M. leprae.

Nos indivíduos resistentes, a repetição de infecções nasais poderia induzir diminuição da resposta imunológica ao antígeno. Isto faria com que, a cada onda epidêmica de infecções de porta de entrada, fosse ampliada a difusão espacial do bacilo, que seria reforçada quando atingidos hospedeiros susceptíveis à "hanseníase-doença", como uma nuvem de dispersão de bacilos em expansão cíclica de seu perímetro de disseminação colonial.

Portadores de infecção transitória, restrita à mucosa nasal, sendo fontes intermitentes ou ocasionais do $M$. leprae, suplementariam as fontes 
representadas pelos doentes bacilíferos, ao mesmo tempo em que poderiam cooperar na reprodução de reservatórios permanentes do bacilo. Deste modo, a disposição de bacilos no ambiente seria proporcionada por doentes contagiantes e secundariamente por portadores transitórios.

A hipótese de ocorrer ondas de infecções agudas subclínicas na população pode complementar as explicações para o surgimento de casos da doença, sem que se tenha identificado qualquer outro doente no perímetro de contato próximo.

A distribuição focal da hanseníase e o arrastado declínio da incidência, mesmo após queda da prevalência (Ganaparati et al., 1999), poderiam ser interpretados considerando, além do longo período de incubação da doença e a permanência oculta de doentes, a difusão da hanseníase em ciclos epidêmicos de infecção não aparente, concorrentes à endemia de casos clinicamente manifestos. Beyene et al. (2003) registraram ampla distribuição de DNA do $M$. leprae em cavidade nasal de indivíduos sadios de uma localidade endêmica, compatível com a hipótese de transmissão subclínica.

Para Benard (2008), ainda não estão caracterizados precisamente os mecanismos que lideram a resposta imune nas infecções granulomatosas crônicas e determinam os eventos que levam ao desenvolvimento de doença ou a um estado de portador crônico.

$\mathrm{Na}$ "hanseníase-infecção", a reposição de indivíduos sujeitos a acometimento de porta de entrada estaria relacionada ao tipo de proteção 
temporária desenvolvida pelo hospedeiro e à dose de exposição. É suposto que a probabilidade de contaminação pelo $M$. leprae dependa do resultado de exposições que acontecem em outros indivíduos. Com o alto poder infectivo do bacilo e a resistência à doença na população adulta perto de 90\% (Lockwood e Suneetha, 2005), a indução de hiporresponsividade coletiva seria um dos caminhos a modular a amplificação do processo endêmico-epidêmico, pela via da exposição em "baixa dose". Mas, na medida em que o contingente de susceptíveis à doença fosse sendo eliminado de um lugar endêmico, um limite crítico de hospedeiros poderia ser atingido e a taxa de reprodutibilidade da infecção se reduziria, comprometendo a capacidade do foco de manter as ondas epidêmicas, pela escassez de casos bacilíferos crônicos. A suposta escassa reprodução do bacilo durante a infecção de porta de entrada tornar-se-ia uma vantagem adaptativa para gerar casos secundários.

A doença crônica bacilífera aumenta o tempo de permanência do caso primário na condição de infectante e a propagação sazonal de infecções de curta duração estende e potencializa, no tempo e no espaço, esta condição que é suplementada por portadores transitórios. As migrações podem alterar o padrão de contato da população e a repetição das infecções de "baixa dose" pode aumentar a susceptibilidade do hospedeiro. A proteção imunológica temporária repõe o contingente de hospedeiros viáveis para infecção. Dentro destas suposições epidemiológicas, a proporção de hospedeiros susceptíveis à doença seria inflada, na medida da extensão e 
longevidade dos ciclos epidêmicos. A infecção, de geração bacilar lenta e a resposta protetora de curta duração do hospedeiro estabeleceriam um efeito na propagação das ondas epidêmicas suficiente para atrasar o processo de difusão do bacilo, mas a favor da reprodutibilidade da infecção em termos populacionais; ou seja, seria esperado que enquanto os indivíduos próximos à fonte contínua estivessem adquirindo "proteção coletiva", nos distantes do caso primário a imunidade de grupo estaria se esvanecendo. Na fase subsequente da onda, as situações se inverteriam.

A eficácia máxima de propagação da infecção seria dependente da ecologia homem-bacilo. Em uma malha interligada de lugares, as ondas epidêmicas não encontrariam "rugosidades espaciais", como aquelas que poderiam advir de um povoamento em "ilhas".

O término da tolerância imunológica pode estar relacionado com a persistência e densidade do antígeno no ambiente, o que poderia ser atingido quando as exposições passassem a se tornar não mais periódicas, em ondas epidêmicas sequenciais, mas ao adquirirem caráter contínuo e mais intenso na população.

A tolerância imunológica parece ser mais facilmente induzida pela repetição da exposição ao antígeno em pequenas doses do que decorrente do estímulo a uma grande e única dose. A passagem de uma forma tolerogênica do antígeno para uma imunógena, parece estar relacionada ao alcance de uma concentração de antígeno, durante as infecções locais, onde a resposta imune resultante passa a ser ótima, fazendo aumentar o 
grau de imunocompetência, que dificulta a indução de tolerância. O controle da tolerância imunológica parece ser dirigido mais perifericamente que a resposta imunológica normal e a recuperação da imunocompetência ser mais rápida que a indução de hiporresponsividade (Waksal, 1980).

Presume-se que estes acontecimentos possam contribuir para arrefecer os ciclos de transmissão, do que se esperaria decaimento da incidência da "hanseníase-doença". Durante o processo endêmicoepidêmico, talvez possa ocorrer um fenômeno de indução de tolerância em "dupla zona". Além da forma tolerogênica de baixa dose do M. leprae, uma forma de tolerância por "alta dose" poderia ser induzida nos indivíduos imunocompetentes, diante de uma "hiperexposição", o que seria plausível para uma parte dos indivíduos que expressam formas clínicas de resistência à doença, tal como paucibacilares que evoluem com cura espontânea, após conviverem em ambiente saturado de bacilos.

O alcance de altos níveis endêmicos poderia passar a expor uma massa de contatos a doses imunogênicas do bacilo, afastando o processo endêmico-epidêmico de uma dinâmica de transmissões indutoras de hiporresponsividade, ao atingir uma carga ambiental do antígeno circulando em doses ótimas para a indução de resposta imunológica eficaz.

O decaimento da endemia poderia advir da recuperação da imunidade de grupo, devido à estimulação e reconstituição da imunocompetência contra as infecções de porta de entrada e do estado de "pico" da endemia, sem reposição de susceptíveis. O efeito epidemiológico 
deste contexto imunitário-populacional poderia demorar a ser observado, em função da latência do $M$. leprae no organismo.

Deste modo, migrações fomentariam a endemia não somente por possibilitarem a renovação de reservatórios contínuos do $M$. leprae, mas também por fazerem circular indivíduos susceptíveis à "hanseníaseinfecção" entre os focos de doença. O comportamento endêmico-focal da hanseníase, em certas áreas formando conglomerados de casos, remete a modelos de propagação por meio de fontes restritas a determinado espaço; por outro lado, o espalhamento dos casos surgidos de não contato, remete à participação de contagiantes assintomáticos, transitórios ou simplesmente ocultos. Na existência de portadores transitórios do M. leprae, a amplitude de sua distribuição espacial poderia suplantar a de doentes bacilíferos, pelo menos em algum momento do processo endêmico-epidêmico.

A Figura 5.1 ilustra a difusão por contágio da hanseníase, levando em conta a hipótese da participação de portadores transitórios, buscando explicar a correspondência espacial entre hanseníase e migrações. No modelo proposto, a endemia de hanseníase se propagaria em função de uma "nuvem" de dispersão de bacilos iniciada por doentes sem tratamento, que seria estendida pela transmissão entre susceptíveis à infecção de porta de entrada nasal. A contaminação da mucosa nasal pelo $M$. leprae poderia estimular resistência imunológica à infecção, gerar casos secundários, mesmo doença de curta duração, com involução espontânea; ou, ainda, 
provocar infecções transitórias, não aparentes e de contagiosidade temporária.

Em ciclos de transmissão curtos, indivíduos portadores de infecções nasais transitórias, mas com potencial contagiante, estenderiam espacialmente a abrangência do risco relacionado à posição da fonte contínua primária de bacilos, para além de seu círculo de contatos. A infecção de porta de entrada nasal proporcionaria a perpetuação do $M$. leprae por mecanismo semelhante ao modo de transmissão, proposto por Matsumoto (1969), para vírus de ciclo curto.

Figura 5.1 - Modelo hipotético sobre a difusão da hanseníase, com a participação de portadores transitórios, indução de hiporresponsividade imunológica e o impacto das migrações

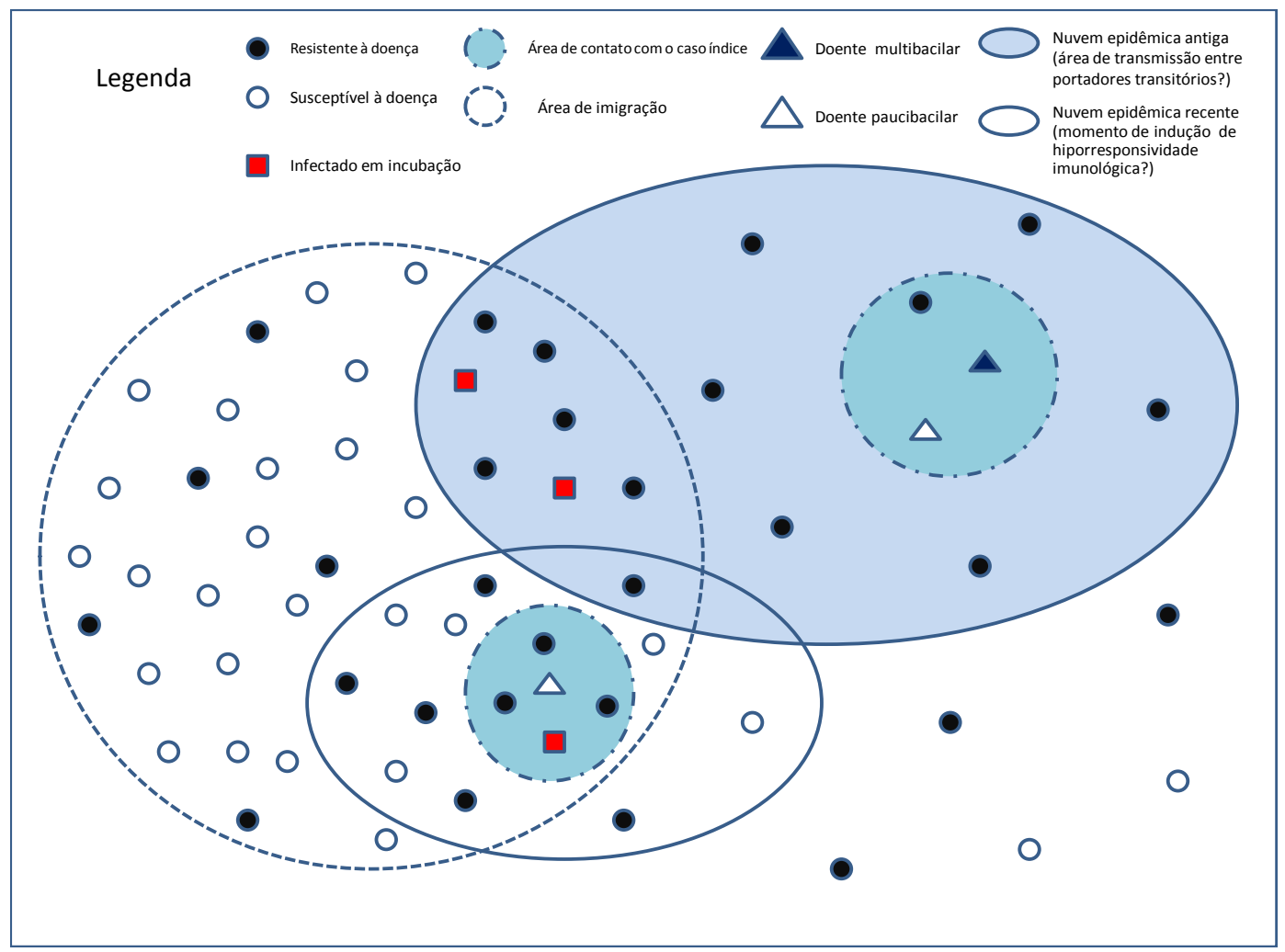


Em comparação ao ciclo curto viral, no ciclo curto da hanseníase, o tempo de sobrevivência do $M$. leprae no ambiente pode ser mais prolongado, permitindo que a transmissão sucessiva a novos hospedeiros possa admitir períodos mais largos de trânsito entre a eliminação do bacilo e a contaminação; e, que, a intimidade do contato físico possa não constituir fator crítico para a sobrevivência do bacilo, embora a dose de exposição possa ser afetada, em função da distância entre o hospedeiro e a fonte de contaminação.

O efeito da repetição de surtos de infecções transitórias, envolvendo parcelas amplas da população (Klatser et al., 1993; Beers et al., 1994), atuaria modificando a susceptibilidade dos grupos expostos ao $M$. leprae e ofereceria contatos com baixas doses de exposição, mas que se somariam no ambiente de abrangência da "nuvem" de bacilos, de acordo com a sua densidade.

Estímulos imunológicos pelo contato repetido com infectantes, mesmo que sazonalmente, poderiam alterar o fenótipo de susceptibilidade do hospedeiro, provocando hiporresponsividade ao $M$. leprae, o que possibilitaria, naqueles susceptíveis à doença, a passagem de uma infecção local, no nível da mucosa nasal, para uma infecção generalizada.

Deste modo, migrações aumentariam as chances de êxito da reprodução de casos, mesmo não sendo a sua contribuição populacional para a endemia lastreada em indivíduos susceptíveis à doença ou em bacilíferos crônicos. 
Nas fases epidêmicas de infecção transitória, supostamente de baixa proteção local de mucosa respiratória no nível populacional, haveria extensão da "nuvem" de dispersão bacilar. Nas fases interepidêmicas, a circulação do $M$. leprae provavelmente se restringiria a uma esfera não distante daqueles capazes de eliminar bacilos continuamente (Figura 5.1).

O recrudescimento da endemia de hanseníase, após a acentuação de correntes migratórias, poderia estar associado à introdução de susceptíveis à "hanseníase-infecção". Matsuoka et al. (2004) verificaram na mucosa nasal de moradores sadios de uma localidade endêmica, a presença de $M$. leprae com genótipos diferentes daqueles identificados nos doentes e em seus contatos domiciliares, revelando a possibilidade de contaminação por fontes alternativas. A comparação das frequências de cada genótipo em diferentes áreas, com os resultados de um levantamento anterior (Matsuoka et al., 2000), indicou que a dispersão de bacilos com genótipos específicos era consistente com a migração de alguns grupos humanos.

No esquema hipotético da difusão da hanseníase representado na Figura 5.2, para atingir indivíduos susceptíveis à doença seria necessário provocar alterações nas defesas imunológicas no nível do grupo, tornando aqueles inicialmente resistentes à infecção (setas pontilhadas), indivíduos hiporresponsivos (setas contínuas).

A endemia de hanseníase seria alimentada pelo sinergismo de dois tipos de ciclo de transmissão: um ciclo longo, endêmico e um ciclo curto, com características epidêmicas. As migrações poderiam fomentar o 
processo endêmico-epidêmico de propagação, criando novos focos ou rompendo os antigos, ao ligarem doentes bacilíferos a não contatos. Bakker et al. (2006) não encontraram diferença de incidência da doença entre não contatos e contatos da vizinhança de casos de hanseníase.

Um ciclo de transmissão longo é presumido para aqueles indivíduos que são contaminados, adquirem infecção, adoecem e que podem ou não eliminar bacilos, algumas vezes de forma contínua; seja em quantidade escassa, como nos paucibacilares ou mais volumosa, tal como observado nos multibacilares, sendo que ambos podem apresentar um demorado período médio de incubação, notadamente mais longo para estes últimos.

Um ciclo curto de transmissão poderia ocorrer após contaminação pelo $M$. leprae, colonização do epitélio nasal do hospedeiro e resposta imunológica específica. Do inóculo inicial resultaria a eliminação de uma baixa quantidade do agente infeccioso no ambiente pela via respiratória, dado que sua multiplicação é lenta, frente ao tempo médio esperado para que o hospedeiro arme proteção específica local de mucosa, a qual, mesmo de duração temporária, poderia mitigar a colônia de bacilos.

A "hanseníase-infecção" poderia ser reproduzida a partir de exposições em condições externas ótimas, tais como aquelas relacionadas ao ambiente físico e à densidade das relações sociais em proximidade.

No entanto, uma diminuta dose de exposição e multiplicação bacilar poderia ser insuficiente para estimular a formação de células de memória imunológica. 
Figura 5.2 - Esquema hipotético de reprodução, no nível coletivo, de casos secundários de hanseníase a partir de contatos repetidos com portadores transitórios do M. leprae

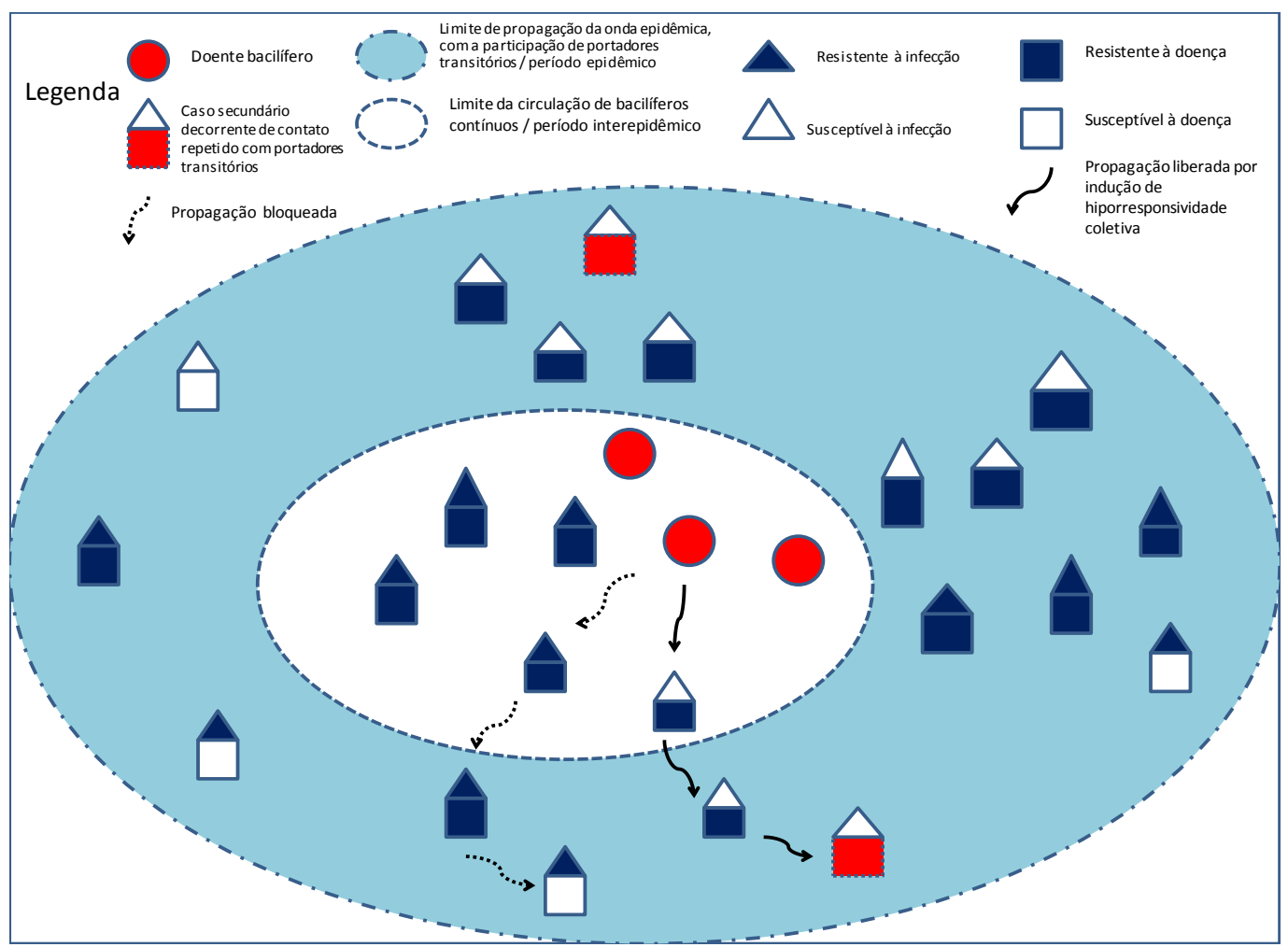

Os ciclos de transmissão da hanseníase refletiriam um encontro em "fase", no nível populacional, do padrão temporal de resposta imunológica do hospedeiro, da biologia reprodutiva do $M$. leprae e de fatores antropossociais e físicos do ambiente.

Smith et al. (2004) notaram que a infecção de mucosa do nariz pelo M. leprae pode assumir um caráter sazonal, relacionado às condições ambientais de umidade.

Um antígeno em quantidade excessivamente pequena poderia levar a um estado imunológico conhecido como "tolerância de baixa dose", onde há 
persistência do antígeno, sem necessariamente redundar em respostas específicas do hospedeiro. Contaminação periódica em baixas doses de antígeno poderia induzir hiporresponsividade imunológica, ao alterar a eficiência dos mecanismos de resistência inespecífica, tal como a resposta fagocitária de macrófagos, que depende do processamento adequado dos elementos bacterianos (Bellanti, 1980).

Todavia, não está descartada a participação de imunidade inata desencadeada pelo encontro com lipoproteinas bacilares; por uma "via direta", poderia haver estímulo para respostas macrofágicas bactericidas (Brightbill et al., 1999). Mecanismos inatos de defesa imunológica, tal como a produção local de citocinas e quimiocinas, que pode se seguir à captação de bacilos por células dendríticas na periferia do sistema imune, e uma adequada apresentação do antígeno aos linfócitos relacionados à produção de memória imunológica, formação de anticorpos e imunidade mediada por células devem concorrer para uma resposta imune eficaz frente à invasão bacteriana (Scollard et al., 2006). Epidemias de "hanseníase-infecção", dependentes da magnitude da doença, poderiam ter repercussões intergeracionais. A intensidade da transmissão do M. leprae no coletivo, expondo crianças em uma fase de imaturidade do sistema imunológico para formar linfócitos de memória, poderia futuramente subtrair parte das possibilidades destes, quando adultos, montarem defesa imunocompetente, frente a um encontro secundário com o bacilo. 
O estado de hiporresponsividade imunológica instalado em parte do coletivo a partir da repetição de ondas epidêmicas ofereceria maiores oportunidades de produzir primeiramente infecção a cada contaminação e depois doença, a cada infecção, alterando a ecologia da interação humana com o $M$. leprae, pois em condições normais o bacilo é raramente patógeno ou causador de doença. $\mathrm{O}$ processo endêmico-epidêmico seria fomentador de virulência, pois interferiria na eficácia de mecanismos imunes da "primeira linha de defesa do organismo", que impedem a aderência e penetração epitelial do trato respiratório e a invasão de tecidos mais profundos, tal como a atividade fagocitária de digestão celular, contra a qual se espera alguma resistência por parte de parasitas intracelulares obrigatórios; e, a neutralização, lise e cobertura antiadesiva direta de mucosa, mecanismos que envolvem a participação de imunoglobulinas da classe $\operatorname{lgA}$ secretória (Bellanti, 1980).

No modelo apresentado na Figura 5.3, os portadores transitórios teriam a função "vetorial" de estabelecer a transmissão do patógeno do doente bacilífero àqueles indivíduos susceptíveis à "hanseníase-doença", distribuídos na população. Uma vez desenvolvida uma espécie de "susceptibilidade coletivamente induzida", a "hanseníase-doença" se propaga, reproduz a "hanseníase-infecção" e a endemia se difunde por multiplicação de focos. 
Para que o surgimento de casos secundários tenha a influência de portadores tornados hiporresponsivos à infecção, talvez seja necessário um longo período de ocorrência de ciclos curtos na população.

A reprodução da hanseníase em nativos tem sido rara em países não endêmicos, a partir de casos clinicamente reconhecidos em migrantes de lugares endêmicos (Worth e Bomgaars, 1982; Boggild et al., 2004). Há relatos do surgimento de casos de hanseníase, em países não endêmicos, entre nativos que retornaram de lugares onde ocorre transmissão, mesmo após breve estada, sem contato reconhecido (Sen et al., 2001); assim como a observação do crescimento do número de casos autóctones, em compasso com o aumento de casos importados (Mastro et al., 1992).

Mesmo com características de infecção de porta de entrada - uma estreita duração e pequena dose de eliminação do agente, tais condições poderiam ser compensadas a favor da eficácia do mecanismo de transmissão, não somente pela contagiosidade e resistência do bacilo no ambiente, mas também pelo seu espalhamento, resultante devido à multiplicidade de infectantes dispostos durante uma onda epidêmica de infecções transitórias; um dos motivos que poderia estar subjacente à conformação de uma descarga efetivamente imunógena do $M$. leprae no ambiente, durante a intensificação deste processo. Haveria continuidade do M. leprae na natureza por repiques sucessivos em uma população em movimento no território, com certa densidade de susceptíveis se renovando a cada intercurso epidêmico. 
Figura 5.3 - Ciclos de transmissão da hanseníase

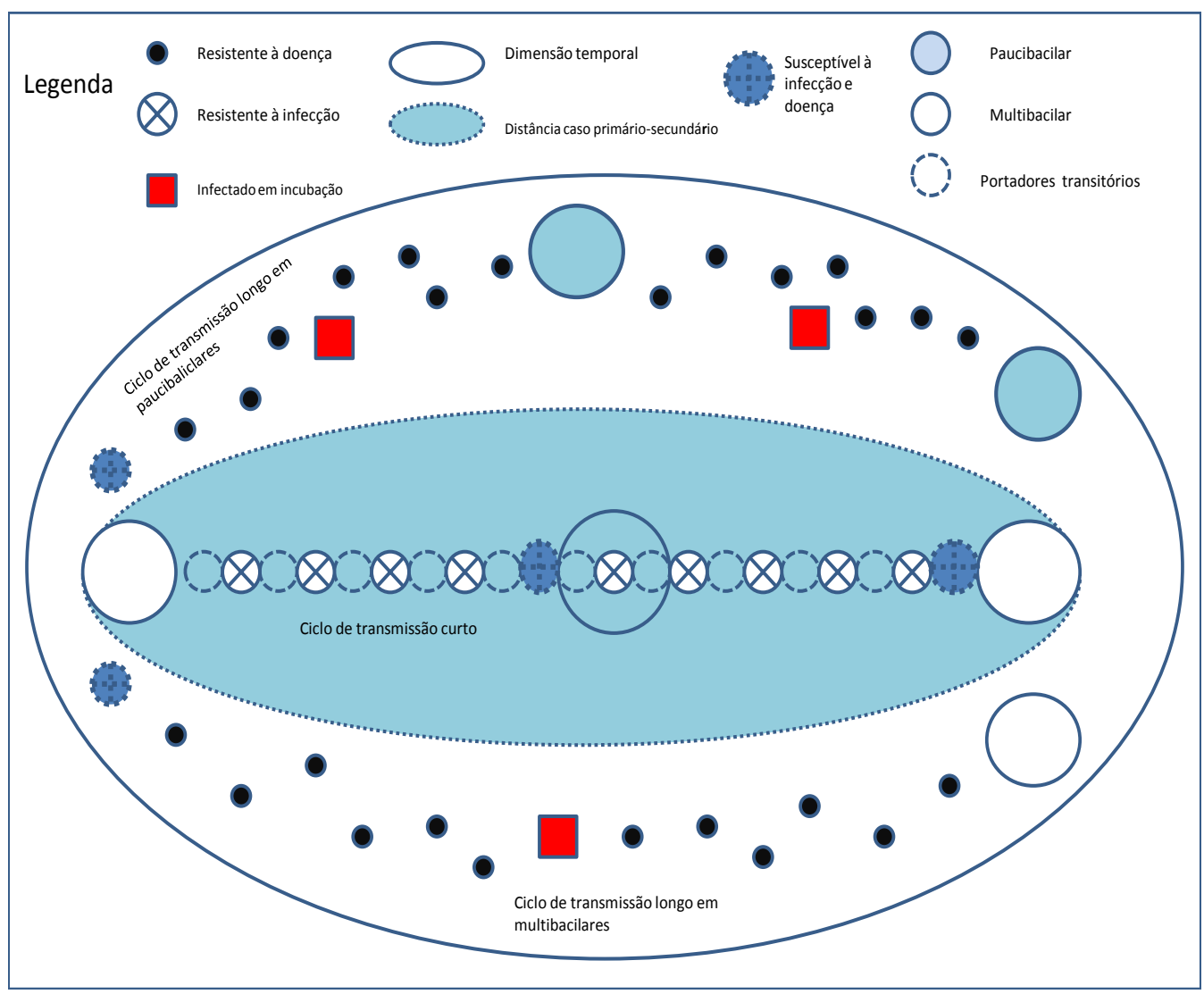

Os mecanismos que regulam a permanência do $M$. leprae na natureza, como uma bactéria de vida intracelular obrigatória, tal como Penna (1988) chamou a atenção para a tuberculose, são de especial interesse à formulação de um modelo epidemiológico para a hanseníase. Os ciclos curtos de transmissão afastariam a dinâmica de transmissão do limiar crítico de hospedeiros disponíveis na população, ao atingirem os susceptíveis à doença; assim como, os longos períodos de incubação seguidos de contagiosidade prolongada garantiriam um alargamento do ciclo biológico 
bacilar e um rebaixamento do nível mínimo da população de hospedeiros necessário à manutenção da espécie. Segundo formas de resistência lançadas pelo hospedeiro, o $M$. leprae seria descarregado no ambiente de forma descontínua (infecções agudas, subclínicas e reincidentes de porta de entrada) e contínua (doença crônica não tratada), a intervalos estreitos (infecção local) e largos (infecção generalizada).

As migrações, ao movimentarem susceptíveis e infectantes, colocariam maiores possibilidades para o encontro sequencial do bacilo com o sistema imune do hospedeiro, o que poderia levar a um decréscimo gradual da resposta por anticorpos e a uma diferenciação exaustiva das populações celulares atuantes, resultando em um estado de tolerância imunológica.

Para um indivíduo susceptível à doença, mesmo uma breve exposição pode ser suficiente para contrair a infecção, se grande número de bacilos viáveis estiver disponível (Meyers, 1998). Em um primeiro momento, as imigrações poderiam fomentar a endemia de hanseníase, mas com a propagação intensificada e o consequente aumento da carga bacilar no ambiente, em paralelo à densidade das transmissões na população, poderia haver um esgotamento de susceptíveis, tanto quanto estivesse sendo retraído o processo imigratório. O dado estrutural representado pelo rápido crescimento demográfico observado no Mato Grosso (Mapa 4.2), à custa principalmente de migrações, ganha importância epidemiológica quando se observa em quais condições ele ocorreu. 


\subsection{Contextualização dos resultados}

Condições naturais ou migrações podem não bastar para justificar uma situação endêmica. Para Silva (1985a), é preciso destacar o âmbito dentro do qual estas condições se determinam, verificando de modo amplo as formas de ocupação do espaço de um dado período histórico.

No modo com que o espaço é desbravado parece residir a construção do vínculo entre hanseníase e ocupação de lugares novos. A ausência de "rugosidades" (Santos, 2006), enquanto "fixos" e "normas" do território, tais como a fertilidade do solo e as leis que orientam as relações sociais no espaço, são fatores que podem direcionar investimentos para a instalação de processos produtivos em "espaços virgens", pois nestes lugares a eficácia do capital costuma ser maior, em termos do retorno do montante investido; e, tão mais quando o Estado já tenha providenciado as facilidades mínimas para sua penetração, seja oferecendo crédito, retirando impedimentos da esfera jurídica e ambiental ou instalando infraestruturas de comunicação e energia.

No Brasil, a capacidade produtiva instalada nos lugares novos tem sido majoritariamente voltada a servir a necessidades da economia internacional de produtos primários, de alto consumo de meios naturais e baixo retorno social para a área que sedia tais atividades. Uma das questões nacionais mais agudas atualmente, diz respeito à capacidade das economias locais gerarem desenvolvimento social. 
No Mato Grosso, entre os períodos de 1996 - 1999 e 2000 - 2006, um padrão espacial de expansão e interiorização da endemia de hanseníase está associado a processos sociodemográficos, destacadamente, às migrações incorporadas à atividade extrativista mineral e à transformação do espaço das cidades, representada pela exclusão social dos moradores periféricos e formação de assentamentos urbanos, durante a ocupação da fronteira agrícola (Soares dos Santos et al., 2010).

No município de Manaus, Imbiriba et al. (2009) observaram que no período de 1998 a 2004, a distribuição espacial da hanseníase seguiu as diferenças no processo de ocupação urbana e mostrou-se concentrada em regiões habitadas por grupos em situação de vulnerabilidade. Cerca de $60 \%$ da população esteve exposta pelo menos a nível muito alto de endemicidade e foi encontrada associação positiva entre taxa de detecção de hanseníase e condição de vida precária. De acordo com os autores, a expansão da endemia nos bairros periféricos de urbanização recente pode ter sido favorecida pelas condições de exposição e susceptibilidade dos migrantes que têm ocupado estas áreas, sendo provável que anteriormente à migração, estas populações tenham tido pouco contato com o M. leprae; e, a dificuldade de acesso a recursos de saúde deve ter prolongado a presença de fontes bacilíferas.

Uma evidência histórica do recrudescimento da endemia de hanseníase concorrente a grandes movimentos migratórios é dada pelo 
processo de interiorização da economia cafeeira do sudeste do Brasil, na segunda metade do século XIX.

Para Maurano (1939), as migrações exerceram influência diretora na difusão da hanseníase no estado de São Paulo, que em meados do século XIX tinha a porção oeste de seu território não extensivamente cultivada, mas pretendida pela economia cafeeira, intensivamente mobilizadora de trabalho. Ele explica a difusão da endemia em um tempo em que não se dispunha de tratamento efetivo para a doença e a comunicação entre as comunidades rurais era extremamente precária. Com o deslocamento do eixo econômico para o oeste do estado, núcleos de povoamento antes isolados e fechados, iam se integrando ao fluxo migratório, mais acentuadamente com a implantação do transporte ferroviário, entre 1865 e 1885, o que contribuiu para romper as zonas consolidadas da doença.

Uma elaboração mais recente sobre a influência de mudanças sociodemográficas no padrão endêmico da hanseníase foi formulada por Belda (1981), quando, ao final da década de 1970, no município de São Paulo, estimou uma concentração de até 58 pacientes de hanseníase por $\mathrm{km}^{2}$, em uma cidade cuja densidade demográfica chegava a alcançar 35 mil pessoas por $\mathrm{km}^{2}$ em algumas localidades. Ele relacionou a escalada da endemia ao crescimento da importância econômica da cidade, que influenciou correntes migratórias e adensamento populacional nos bairros periféricos. Sobre a transmissão extradomiciliar em ascendência, considerou a diminuição da convivência familiar, consequente a alterações dos padrões 
socioeconômicos, com repercussões nas possibilidades de transmissão da hanseníase por contatos repetidos e fortuitos; e, chegou a ponderar sobre as chances da metrópole, de centro importador de casos, passar a ser foco de hanseníase.

Dias et al. (2005), após a análise de dados de campo e censitários concluíram que a hanseníase, no município de Mossoró, está mais concentrada em bolsões localizados em áreas periféricas, onde reside a população com baixo padrão socioeconômico.

Em outros países, mudanças na epidemiologia da hanseníase também foram relacionadas às movimentações da população em busca de trabalho e o advento de uma urbanização em condições insalubres.

Entre 1950 e 1975, na Polinésia francesa, houve um recrudescimento da endemia de hanseníase após vários anos da doença sob controle. Paralelamente ao aumento das taxas de deteç̧ão da doença, a população dobrou de tamanho neste período e sofreu modificações profundas em sua estrutura e relações sociais, que foi do "colonial tradicional" ao "modo de vida moderno", com forte influência da imigração europeia e impulso das atividades comerciais e de comunicação. É relatado para este período um rápido crescimento urbano, formação de favelas, superpovoamento da periferia da cidade, aumento da população desabrigada, intensificação da migração rural-urbana e dos fluxos populacionais interinsulares, problemas na absorção da mão-de-obra recém-chegada do meio rural e deterioração da qualidade das habitações e das condições de higiene. Na avaliação dos 
autores, o grande movimento migratório observado moveu os "peões do xadrez" epidemiológico da hanseníase e rompeu os focos antigos da doença, espalhando-os para a zona urbana da cidade (Merlin et al., 1976).

Em uma área do Pacífico Central, o declínio da endemia de hanseníase tem sido atribuído mais ao provável aumento da resistência ao bacilo do que à falta de exposição, pois é presumido que esta ainda continue. Trabalhadores que migraram para lugares endêmicos, ao retornar, acabaram estabelecendo focos de hanseníase, sendo que estes focos foram mantidos por mais de 40 anos em populações que tinham sido submetidas a privações socioeconômicas e deslocamento constante (Worth, 1996).

As correntes migratórias, muito ligadas à busca de ascensão social, acabam sendo alimentadas majoritariamente pela população dos estratos econômicos mais depauperados da sociedade. A endemia de hanseníase é dependente de dinâmicas populacionais renovadoras do compartimento de susceptíveis, da transposição de focos de doentes e das características dos contatos. As correntes migratórias, especialmente aquelas direcionadas à ocupação de lugares novos, inserem a hanseníase em uma relação original com o espaço usado. 


\section{Fronteira agrícola e migrações}

Embora haja estreita ligação dos aspectos demográficos com a organização espacial da economia, a procura de emprego não representa razão suficiente para explicar as migrações. Segundo Santos (2004), migração é uma das consequências das modernizações, que têm como resultado a concentração das unidades de consumo e a pulverização da produção, o que obriga a uma maior fluidez espacial, sobretudo mediante diferenças espaciais consideráveis nas condições de produtividade e mais maciças quando contemporâneas a um crescimento acelerado da população, o que pode produzir o efeito de expulsar a população do meio rural.

O MT se destaca pela atividade de fronteira agrícola, onde tem ocorrido o povoamento de lugares novos, intensa mobilização populacional e rápida urbanização. Becker (2004), estudando a região Amazônica, cujos limites legais incluem o Mato Grosso, faz referência à intensa mobilidade do trabalho rural entre as décadas de 1970 e 1980, aos conflitos de terra, à formação de inúmeros e pequenos aglomerados urbanos e à rapidez e escala da ocupação regional da área de fronteira. Na fronteira agrícola, muitas vezes, a urbanização precede os processos econômicos, em um espaço não plenamente estruturado. A partir da década de 1990, com a abertura de algumas estradas de rodagem, a conquista de uma dupla via comunicacional para a região amazônica também repercutiu nas migrações 
e na mobilidade do trabalho e influenciou a constituição de um perfil predominantemente urbano de povoamento, mas com ausência material da cidade e de sua base produtiva.

Para Silva (2006), a fronteira agrícola constitui o recorte analítico e espacial da problemática da mobilidade, do ponto de vista das relações de produção capitalista, revelando interações entre o homem e a natureza, o modo com que parcelas da população são inseridas nos círculos de cooperação modernos da economia e as condições gerais de reprodução social.

A fronteira agrícola contemplaria a porção demográfica indígena em face com a vanguarda de ocupação, chamada por Martins (1997) de "frente de expansão": ponta de absorção dos recém-chegados, sustentada por uma economia de excedentes. Na fronteira, a abertura de núcleos urbanos e a atração da população ao redor de cidades e principais vias de circulação denotam um dinamismo demográfico sem uma efetiva densidade de população no campo, compatível com a base técnica requerida pela agricultura. Este excesso demográfico diante de uma baixa absorção econômica da mão-de-obra rural está entre as condições que ajudam a entender a relação entre a hanseníase e a fronteira agrícola, pois ela prenuncia a exclusão do acesso à renda, as possibilidades de moradia e a necessidade de circulação em busca de trabalho. Com isto, a movimentação populacional que marca, principalmente, a fase pioneira de ocupação do território, poderia influenciar a convergência das premissas naturais para a 
difusão da hanseníase, ligadas à necessidade de que hospedeiros susceptíveis sejam repostos.

Coutinho (2009) sobrepondo os pontos de queimadas com o "Mapa de Vegetação e Uso das Terras" mostra que, no MT, entre 1995 e 2001, as queimadas estiveram correspondendo às áreas de expansão da fronteira agrícola, principalmente na floresta de transição; e, entre 2002 e 2003 as queimadas passaram a ocorrer também em florestas mais densas.

Silva (2006) considera a fronteira agrícola capitalista do fim do século $\mathrm{XX}$, que inclui o cerrado mato-grossense, como um processo de integração geográfica da economia nacional e global, iniciado na década de 1970 e que corresponde à fase de consolidação do padrão de acumulação urbanoindustrial iniciado nos anos de 1930. O MS surge da divisão territorial do antigo Mato Grosso ao final da década de 1970. Alguns municípios do novo estado contavam com uma densidade populacional acima de 50 hab. $/ \mathrm{km}^{2}$, em contraste com o norte, atual estado do MT, um "deserto humano", como era chamado. Na segunda metade do século XIX, a região ao sul do antigo Mato Grosso, palco da Guerra do Paraguai, passa a receber um expressivo contingente de migrantes nacionais e estrangeiros, principalmente advindos de países fronteiriços. Com o surto econômico da borracha do início do século XX e a implantação da linha férrea entre Corumbá e Bauru, em 1914, o crescimento demográfico e econômico do sul do estado torna-se ainda mais intenso, estabelecendo já desde aquela época, a área que hoje compõe o MS, como sendo a mais povoada. 
O período que antecede a década de 1930 contou com o excedente agrícola e comercial da economia do café, a mobilização de mão-de-obra nacional e estrangeira; e, a instalação de grandes infraestruturas, que deram ao estado de São Paulo e suas áreas de fronteira com o MS e Paraná, a fluidez necessária para distribuir a produção e integrar a economia cafeeira ao capital internacional. Na década de 1930, a integração do mercado nacional pela interiorização da economia foi um dos objetivos do governo de Getúlio Vargas. Nesta época, foram implantados vários projetos de colonização no Centro-Oeste, que compunham a iniciativa que ficou conhecida como "Marcha para Oeste"; o município de Dourados, ao sul do MS, teve influência de seus desdobramentos demográficos. Nos anos de 1950 e 1960, a instalação de obras infraestruturais, principalmente de transporte rodoviário, previstas no Plano de Metas do governo Juscelino Kubitscheck, forneceu bases modernas para a ligação da região CentroOeste à economia nacional. O processo de ocupação por meio de frentes de subsistência e de pecuária extensiva e rudimentar passou a se fazer ao lado de uma agricultura comercial, uma bovinocultura baseada em técnicas científicas e da intensificação de fluxos migratórios (Almeida et al., 2006).

Durante os governos militares das décadas de 1960 e 1970, a intervenção federal sobre o Centro-Oeste, ainda considerado um "vazio humano", se fez por meio de programas de desenvolvimento econômico, vinculados aos "corredores de exportação", que previam a instalação de infraestruturas e concessão de isenção de impostos e subsídios 
governamentais, visando o aumento da produção e da produtividade (Bernardes, 2007).

Para Almeida et al. (2006), isto contribuiu para esboçar a estrutura produtiva e a urbanização prevalente na fase atual e assegurar, ao capital privado, as condições de investimento e introdução na região, expandida a partir das características de fronteira agrícola, com grandes extensões de terra a preços relativamente inferiores aos das regiões Sul e Sudeste do Brasil. É na década de 1960 que a cultura da soja é trazida para o sul do MS, marcando a fase da adaptação da oleaginosa no cerrado e uma incipiente atividade agroindustrial de beneficiamento de grãos.

Cunha et al. (2002) consideram que a dinâmica socioeconômica e a configuração demográfica-espacial observadas no MT guardam semelhança com processos geográficos ocorridos em Goiás e no MS, que tiveram a ocupação de seus territórios em um período precedente. No entanto, com uma intensificação do povoamento e das atividades econômicas em um período mais recente das modernizações, o MT sofreu os impactos das grandes transformações na estrutura produtiva e fundiária regional de forma precoce, fato que esteve conectado a sua dinâmica migratória, de trajetória mais curta que a observada naqueles outros estados.

Segundo Almeida et al. (2010), durante as décadas de 1970 e 1980, a região Centro-Oeste assistiu a uma grande expansão da agropecuária. $\mathrm{Na}$ década de 1980, enquanto para o resto do país se verifica uma baixa expansão da atividade econômica e expulsão da mão-de-obra excedente 
das áreas industrializadas, o Centro-Oeste continua em pleno crescimento populacional, econômico e agropecuário, principalmente pela opção governamental de gerar divisas por intermédio da exportação de produtos primários. No MT, até a década de 80 , foi intenso o movimento migratório ligado à expansão da fronteira agrícola, de origem predominantemente sulista; e, à atividade garimpeira, que atraiu majoritariamente os nordestinos. Houve concentração e valorização fundiárias, crescimento dos mercados regionais e incorporação de pequenas propriedades familiares pela expansão da monocultura, o que, ao mesmo tempo, contribuiu para esvaziar o campo e impulsionar as frentes de povoamento para as regiões mais ao norte do MT, Rondônia e sul do Pará.

Santos e Silveira (2005) consideram que variáveis do contexto histórico que comandaram o êxodo rural no Brasil ao final do século XX combinavam uma estrutura fundiária arcaica, em zonas agrícolas tradicionais; com a modernização mecânica e científica do campo, em zonas dinâmicas e em áreas de colonização agrícola e ocupação recente. No Mato Grosso, o meio técnico-científico-informacional se estabelece sobre um território praticamente natural, denominado de "pré-técnico": um espaço com baixa "rugosidade" material e organizacional para a implantação de inovações e extremamente receptivo a novos fenômenos da urbanização. Este fato, em parte justifica a breve trajetória do MT no processo de redistribuição espacial da população brasileira, em comparação aos outros 
estados da região, uma vez que na década de 2000, já não sustentava o mesmo ímpeto migratório observado anteriormente.

Dotado de poucos recursos financeiros e baixa escolaridade e, ainda, dependente do trabalho familiar e dos recursos naturais do solo, o migrante tem dificuldades para explorar terras pouco produtivas e permanecer inserido mercado de trabalho urbano. Com o excedente demográfico gerado na desarticulação da antiga atividade rural e a baixa capacidade dos centros urbanos locais em absorver os imigrantes, uma massa de pessoas retorna a sua origem ou reemigra, notando-se, no MT, ainda nos anos 90, uma "desruralização" com inchamento urbano e contínuo movimento da fronteira (Cunha et al., 2002). Entre 1985 e 1995 o emprego agrícola diminuiu 19\% no Centro-Oeste. Com o deslocamento de capitais do Sudeste e Sul para o Centro-Oeste e a consolidação da agricultura comercial do complexo "grãoscarne" na década de 1980, as culturas tradicionais não encontram apoio governamental e perdem espaço para a produção das culturas de exportação. As culturas de soja, milho e algodão, fortemente dependentes de insumos químicos e novas variedades genéticas, apresentaram crescimento da área plantada e dos rendimentos no período, no entanto, a sua capacidade de fixar a renda na própria região de cultivo é incipiente, dada especialmente à baixa geração de empregos, mesmo em grandes extensões de terra.

No Brasil, entre 1970 e 1995, a atividade rural com maior expansão é a pecuária de corte, especialmente no MT e MS. Igualmente à monocultura 
agroexportadora, a pecuária de corte apresenta baixa capacidade de fixar renda na região de produção e baixa oferta de emprego. Alves (1999) afirma que, na década de 1990, a agricultura brasileira atravessou uma fase onde esteve direcionada a uma agricultura baseada na ciência, em um número pequeno de agricultores e pouco empregadora de mão-de-obra assalariada. A tecnologia mecânica substituiu os trabalhadores que deixavam o campo e aumentou a velocidade do êxodo rural. Ao final do século XX, o CentroOeste, a principal fronteira agrícola do país, é caracterizado por uma estrutura de produção pouco diversificada, reduzida capacidade de absorção populacional e alta dependência de mecanização e da pecuária extensiva. A formação de pequenas cidades com grande descompasso entre a pujança produtiva do campo e a capacidade de ocupação da população migrante e sua efetiva inserção socioeconômica, acabou alimentando a migração e sujeitando uma parcela dos citadinos a um padrão de vida urbana em condições insalubres. Na década de 2000, o Brasil atinge índices de urbanização similares aos de países avançados, mas manteve a proporção da população urbana dedicada à atividade rural em torno de $25 \%$ da população ocupada, bem distante dos países industrializados, onde essa relação é menor que 6\%. Para o mesmo período, o Pessoal Ocupado com a Agricultura (POA) por unidade de PIB agrícola teve decréscimo acentuado, traduzindo um consumo menor de trabalho para a produção de uma mesma unidade de produto agrícola. 
Estes fenômenos da formação do território tornaram a hanseníase, antigamente tida no Brasil como uma endemia rural, uma doença focalizada nas áreas urbanas depauperadas. Mas esta transferência rural-urbana teve particularidades, segundo o contexto que esteve fundamentando a movimentação populacional.

Um duplo movimento migratório, de entrada de migrantes e ainda rural-urbano, tem sido corroborado no MT por processos de valorização da terra, consequentes à consolidação das frentes pioneiras (Santos e Silveira, 2005). A região Centro-Oeste, entre 1940 e 1996, experimentou o maior declínio percentual de população rural do país, que passa de $77 \%$ para $15 \%$. No MT, sobretudo a partir da década de 1970 do século XX, observa-se um grande aumento do número de aglomerações, com urbanização simultânea às vagas de povoamento e combinada à presença de colonização descontínua, de forte atração de mão-de-obra, baixa densidade técnica e de capitais e sob um espaço de menor fluidez em comparação ao Mato Grosso do Sul.

De acordo com o Censo demográfico de 2000 (IBGE, 2008), um número de 362 mil pessoas não naturais, imigrantes nos últimos 10 anos, permanecia no MT; esta cifra, para o MS, foi de 176 mil pessoas. No MT, 424 mil pessoas declararam que não residiam no mesmo município há cinco anos e para o MS este quantitativo foi de 261 mil pessoas.

Analisando dados da Pesquisa Nacional por Amostra de Domicílios PNAD 2008 (IBGE, 2010b) quanto à naturalidade em relação ao município, 
verifica-se que em 2008 a proporção da população residente não natural é maior na região Centro-Oeste, representando $54 \%$, enquanto que para o país como um todo foi de $40 \%$; no MS ela foi de $51 \%$ e no MT $61 \%$, a maior entre todos os 27 estados. A naturalidade, em relação à Unidade da Federação, aponta uma maior proporção da população residente não natural na região Centro-Oeste, com 36\%; e, no Brasil, de 16\%; no MS ela foi de $29 \%$ e no MT $41 \%$, sendo também a mais proeminente do país.

Traçando um paralelo no tempo, é importante citar que no Sudeste, particularmente em São Paulo, a modernização ocorrida a partir de meados do século XIX propiciou a difusão da mecanização do território, com repercussões inclusive para a área em que se constitui hoje o MS. Isto fez com que este estado "antecipasse", em algumas décadas, em relação ao Mato Grosso, o processo especulativo fundiário, a instalação de uma rede de cidades locais com uma cobertura de povoamento predominantemente urbana, uma maior diversificação da produção, do consumo e segmentação das classes sociais; e, uma mais densa implantação de infraestruturas sanitário-assistenciais, de circulação e de comunicação. A localização privilegiada do MS, pela menor distância em relação aos mercados consumidores do Sudeste, ainda concorreu para torná-lo mais eficiente aos interesses do capital do que o MT. A incorporação econômica das áreas demograficamente rarefeitas do cerrado mato-grossense ocorreu de forma mais tardia, em relação ao MS. No entanto, ao final do século $X X$, é referido ao MT um vigoroso e desconcentrado crescimento urbano, representado 
pela proliferação de pequenas cidades, mas com a novidade representada pelo fato do centro de regulação das atividades agrícolas estar, agora, preferencialmente radicado fora do ambiente rural e a população voltada ao campo se estabelecer na cidade, ou seja, nota-se uma dissociação entre os lugares de vida e de trabalho. Segundo Santos e Silveira (2005), esta diferenciação rural-urbana, moldada sob um quadro novo, assegura a cooperação cidade-campo necessária à divisão social do trabalho agrícola, que surgiu de um novo conteúdo técnico da produção, afinado às exigências de produtividade e competitividade de um mercado territorialmente ampliado.

No início da década de 2000, a expansão de fronteiras agropecuárias no MT envolvia áreas ao longo da rodovia Cuiabá-Santarém e notava-se uma intensificação do processo produtivo agrícola na área que inclui a faixa norte do estado (Becker, 2004). Esta área apresenta indicadores epidemiológicos que apontam tendência de propagação e maior severidade da endemia de hanseníase; e, o quadro sociodemográfico, do ponto de vista das condições de vida, apareceu como sendo o mais desfavorável relativamente ao restante da área em estudo.

Magalhães e Rojas (2007), depois de detalhados estudos geográficoepidemiológicos, são enfáticas em afirmar que o avanço da fronteira agrícola promoveu a expansão da endemia de hanseníase.

Sabroza et al. (1992) colocam as grandes movimentações demográficas relacionadas ao circuito inferior da economia e ao modelo de desenvolvimento do país, como um fator que contribui para aumentar a taxa 
de contatos na população; e, por consequência, as taxas básicas de reprodução dos parasitos (Coutinho, 2004), o que ocorre em especial aos germes de transmissão respiratória, onde a aglomeração e a precariedade sanitária das habitações seriam ainda outros ingredientes a fomentarem a transmissão, ao facilitarem o contato e a persistência de agentes infecciosos no ambiente.

\section{Circuito inferior da economia urbana}

A desproporção com que a hanseníase incide nas regiões subdesenvolvidas do mundo e a concentração de casos nas periferias urbanas está enlaçada a aspectos da formação do espaço social. Barata (2005) alinha que as populações respondem à pressão das macroestruturas econômicas produzindo perfis diferenciados de adoecimento, segundo seu lugar social. Barcellos (2008) fala sobre o encontro singular de quando a doença incorpora uma geografia, através de uma organização do espaço que, ao mesmo tempo em que instala os riscos, particulariza as populações que serão expostas.

Para Silva (2006), o espaço geográfico pode ser entendido como fator e produto das práticas sociais, que desvelam a própria formação do território. Estas práticas sociais se materializam a partir de pré-requisitos de uma ordem espacial preexistente nas áreas por onde ela se instala, 
mobilizando forças humanas e naturais. A inovação constante na área tecnológica e de serviços tem destinado parte da população a repetir deslocamentos, ocupar a periferia das cidades e a superpor, aos circuitos econômicos modernos, divisões de trabalho e comportamentos correspondentes à escassez de meios de vida.

As novas necessidades impostas pela modernização às pessoas sem renda conduzem a soluções que Ihe são próprias, mas que acontecem em um âmbito coletivo. O modelo de desenvolvimento econômico tem sido acompanhado de imperativos no plano tecnológico que acarretam a limitação das possibilidades no domínio da substituição dos fatores de produção (Santos, 2009). Isto tem provocado uma rigidez no mercado de emprego que impede sua expansão, fazendo com que, nos países subdesenvolvidos, o crescimento industrial possa vir acompanhado de subemprego e de não emprego, que pode ser agravado na passagem de uma situação de mercado de competição a uma de oligopólio. Nota-se que no Brasil, na medida em que a industrialização avança, a urbanização tornase mais "terciária" (Santos, 2004).

A influência modernizadora sobre o mundo rural se exerce criando vínculos de cooperação com a produção urbana, onde a cidade entra em contato com o êxodo rural ao abrigar parte da força de trabalho no setor terciário "primitivo". Devido à má distribuição de rendas, é por intermédio dos serviços que a maioria da população participa da acumulação que se realiza na cidade. Isto torna o consumo de serviços pessoais um dos elementos 
importantes do padrão de vida. A prestação de serviços abriga muitos recém-chegados, em vista da maior facilidade em encontrar uma ocupação nesse setor, quando não se dispõe de preparo profissional ou recurso financeiro (Santos, 2009).

No ciclo de condicionamento social da hanseníase é importante o fato de que a carga mais pesada da modernização e do custo social dos planos de desenvolvimento no Brasil ter sido suportado pelos pobres, pelos de baixa renda e desempregados. Isto tem tornado a urbanização um processo refratário a abolir a pobreza, que se acumula na medida da concentração econômica e espacial (Santos, 2004). O baixo investimento público na área social tem contribuído para a persistência de uma série de endemias, aumentando os prejuízos à saúde coletiva, ao compelir aqueles que não têm acesso aos recursos de saúde a um estado de cronicidade, de sofrimento físico e psíquico e de exclusão do trabalho, da família e da vida social.

Estas condições de evolução da economia e o peso da população urbana com baixo nível de vida, que cresce com o êxodo do campo, impelem à formação de um circuito econômico paralelo nas cidades, essencialmente baseado no emprego. Este circuito econômico consiste de atividades em pequena escala e compreende a pequena produção manufatureira, frequentemente artesanal, o pequeno comércio e uma multiplicidade de serviços completamente adaptados à abundância de mãode-obra e escassez de capital (Santos, 2003), sendo particularmente exemplar, na atualidade, a proliferação de catadores avulsos de materiais 
recicláveis, os "carroceiros", com seus veículos de tração humana e a multiplicação de comerciantes que inauguram seu estabelecimento sobre o próprio corpo, tal como os vendedores ambulantes. Estas atividades econômicas são fundamentais para a vida urbana dos países subdesenvolvidos, por seu papel de refúgio para a população pobre, migrante ou originária da cidade, constituindo-se em um mecanismo de integração social permanente (Santos 2009).

O fracionamento e a descontinuidade das atividades do circuito inferior criam uma gama de serviços de contato e de articulação, que permite gerar uma grande quantidade de postos de trabalho; e, toda uma cadeia de outras atividades e relacionamentos em contatos pessoais, onde frequentemente o próprio terciário do setor moderno estabelece seu círculo de serviços de nível inferior (Santos, 2002).

Como uma variável que the é própria, a chegada incessante de pobres na cidade incha o circuito inferior e modifica sua importância na economia local, ao mesmo tempo em que renova seus quadros pela base: uma força de trabalho muitas vezes sem qualificação e desprovida de capital, que não pode ser absorvida pelo circuito moderno, mas tem ocupação no circuito inferior e em atividades sazonais, regionais e urbanas (Santos, 2004).

O processo endêmico, um híbrido natural-social, comporta uma historicidade, pois para que a doença adquira um caráter endêmico, particularizado e delimitado é necessário que o espaço seja apropriado 
socialmente, ganhe uma intenção de uso dentro de um coletivo, que passa a organizá-lo segundo uma finalidade, que pode ser própria ou até estranha ao lugar. Pode-se alinhar que, para a área em estudo, o modo com que as migrações e a urbanização se objetivaram geograficamente, foram estabelecidos os pré-requisitos espaciais ao processo de propagação da hanseníase, o que condicionou a distribuição da doença ao compasso de formação do território. As variáveis que forneceram a estrutura demográfica necessária para que o espaço cumprisse a finalidade social que the foi historicamente atribuída, estiveram em correspondência com a renovação do contingente de susceptíveis e a concentração urbana periférica em condições de vida favorecedoras da efetividade da exposição ao $M$. leprae em reproduzir a doença.

\subsection{Sobre o processo investigativo}

O grau em que foram registradas as informações sobre hanseníase no Sinan é um ponto-chave na avaliação da qualidade dos dados epidemiológicos utilizados na pesquisa. Segundo Queiroz e Scatena (2009), até 1999 o estado de Mato Grosso utilizava um sistema de informação próprio para a comunicação de casos de hanseníase, tendo naquele ano aderido ao Sinan e iniciado um período de transição em que houve a 
migração da base de dados estadual para a base nacional, processo acompanhado de um fluxo inverso de descentralização operacional do sistema, do estadual para o municipal.

No Brasil, os doentes de hanseníase são assistidos primordialmente em serviços ambulatoriais do SUS. Em 2005, o SUS dispunha de uma rede ambulatorial abrangendo geograficamente todos os municípios do MT e do MS (Brasil, 2011c). Entretanto, perda de informação em hanseníase, a custa de não cobertura efetiva do SUS ou do Sinan e falhas na obtenção de dados dos estabelecimentos de saúde notificantes são possibilidades difíceis de serem completamente afastadas. Segundo dados do Cadastro Nacional de Estabelecimentos de Saúde - CNES (Brasil, 2011c), em 2005, no MT, seis municípios não contavam com profissionais médicos do SUS, ausência não observada no MS; e, existiam 43 unidades de vigilância epidemiológica ou sanitária para 128 municípios (no MS, 62 unidades para 78 municípios). Entre 2000 e 2006 a média de consultas médicas básicas do SUS por hab./ano (Brasil, 2006a) esteve abaixo da unidade em 12 municípios do MT e em nove municípios do MS.

Eliminar duplicidades de registros referentes a um mesmo evento pode ser uma tarefa difícil no gerenciamento da informação epidemiológica, mesmo quando se dispõe de tecnologias de informação potentes. Por outro lado, perda de informação pode ocorrer durante processos de migração de dados entre diferentes versões, plataformas ou sistemas de armazenamento e recuperação de dados. A implantação iniciada em 2007 do aplicativo 
computacional do Sinan para registro de informações desenvolvido em uma linguagem de programação sob a plataforma Windows (Ministério da Saúde, 2008), em substituição ao Sinan-DOS, implantado em 1993 (Laguardia, 2004), ocorreu em seguida ao período de referência dos dados epidemiológicos (2000 - 2006).

Mesmo contando com recursos assistenciais e de vigilância em saúde, alguns municípios podem não dispor de sistemas adequados de supervisão da alimentação do Sinan, o que provoca questionamentos sobre a confiabilidade das informações produzidas no nível local e municipal, onde são consolidados os dados. Isto faz com que a utilização dos indicadores gerados possa sofrer restrições para a avaliação epidemiológica e operacional (Raposo, 2011).

Lima (2010) observou que, no Brasil, os fatores determinantes da qualidade dos dados dos sistemas de informação em saúde não são regularmente controlados, não existindo uma tradição em qualificar as informações em saúde, nem uma coordenação nacional com esta atribuição.

Peiter (2005) considera que a qualidade da informação dos bancos de dados de saúde disponibilizados pelo Datasus vem sendo aprimorada; mas, comparando dados epidemiológicos secundários do Datasus e de Secretarias Estaduais de Saúde, ainda observou discrepância entre estas fontes.

Ignotti (2004) lembra que em 2001 foi completada a implantação do Sinan nos municípios do MT, o que vinha gerando instabilidade nos registros 
de casos de hanseníase; e, naquele mesmo ano, foi implantado um programa estadual para fomentar a detecção da doença nos municípios. Os municípios poderiam ser premiados ao atingirem as metas do plano de controle; e, as equipes de saúde ou seus componentes, bonificados a cada suspeição, detecção ou cura alcançada de hanseníase.

Antecedendo as interferências do sistema de informação, a habilidade em reconhecer a doença exerce efeitos multiplicativos na estimação da incidência de hanseníase, podendo provocar tanto subdetecção, como supradiagnóstico. Em torno de $30 \%$ das lesões de hanseníase não apresentam anestesia (Walker e Lockwood, 2006), embora este seja o aspecto mais significativo para o reconhecimento clínico da doença. No Brasil, é suposto que o diagnóstico de hanseníase esteja sendo realizado em bases essencialmente clínicas e o acesso a recursos baciloscópicos, anatomopatológicos e testes cutâneos para avaliar a integridade da função neural tem sido restrito. Trindade et al. (2008) observaram que a sensibilidade diagnóstica melhorou com a colaboração, à distância, de médicos dermatologistas experientes, lotados em um ambulatório de hospital de ensino; entretanto, o impacto da teleavaliação na especificidade diagnóstica foi considerado baixo.

No estabelecimento de nexos entre situação epidemiológica e sociodemográfica pode-se incorrer em associação espúria e tendência a uma descrição genérica das relações entre variáveis. Estes são flancos vulneráveis desta pesquisa, próprios aos estudos estatísticos de 
populações, onde são obtidos quadros resumidos da realidade, quando é aceito que características individuais sejam dissolvidas na unanimidade das médias (Cândido, 2001). Uma enumeração das singularidades dos casos detectados pode ter significado epidemiológico relevante para 0 esclarecimento da epidemiologia da hanseníase, mas os dados aproveitados aqui para a análise se referem ao grupo.

O que se procura na análise de agregados é a medida do efeito ecológico no risco de doença, se possível, em separado do efeito individual. Nesta pesquisa foi obtido o efeito ecológico - biológico e contextual, conjuntamente, de variáveis sociodemográficas sobre a taxa de deteç̧ão de hanseníase. Os efeitos ecológicos observados, para serem adequadamente interpretados como sendo efeitos contextuais, necessitariam de um controle para confundidores medidos no nível individual (Morgenstein, 2008).

Para tentar minimizar o viés que poderia brotar das diferenças entre os grupos é necessário torná-los validamente comparáveis para aqueles aspectos "externos" ao modelo, supondo que pudessem influenciar a taxa de detecção de hanseníase. A padronização das taxas de detecção de hanseníase por idade foi um artifício aplicado com esta preocupação.

A interpretação dos efeitos ecológicos demandou a representação de uma rede de causalidades em diferentes níveis, que serviu de base para pensar o processo multifatorial e oferecer significado aos resultados empíricos. Foram destacados os dados estruturais da economia e algumas regras de seu funcionamento, pois estas informações são necessárias para 
a interpretação das estatísticas sociais (Santos, 2004). Com este modelo, foi buscado superar as linearidades de "causa e efeito" e oferecer um valor sistemático para as variáveis explicativas, dentro do que poderia ser considerado biologicamente plausível na relação entre hanseníase e contexto sociodemográfico; e, deste modo, tentar evitar associações espúrias.

Um modo tradicional de explicar o processo endêmico se faz pela abstração lógica de uma estrutura composta pelo agente, hospedeiro e ambiente, onde cada um destes elementos possui autonomia de significação dentro do modelo teórico. No entanto, a sucessão de eventos altera o efeito do contexto, ao tempo que os lugares respondem a uma determinada conjuntura que também modifica o significado das variáveis que representam o fenômeno endêmico. Para não perder de vista este dinamismo, foi necessário extrapolar a escala espacial dos dados empíricos e ampliar a análise para alguns aspectos da economia nacional que têm posicionado o país dentro do mercado globalizado de produtos primários e influenciado a ocupação de lugares novos. Na escala temporal, foi registrado que muito anteriormente à fase atual de constituição do território em estudo, a instalação de grandes objetos técnicos (rodovias, ferrovias, mecanizações agrícolas etc.) e movimentações populacionais, já demarcavam a diferenciação socioeconômica e demográfica entre MT e MS e uma epidemiologia da hanseníase própria a cada um destes subespaços. 
Uma fragilidade deste estudo, além da premissa de separação das variáveis, é a completude da lista de variáveis independentes consideradas relevantes, pelo papel que poderiam exercer na explicação da taxa de detecção. Mesmo partindo de uma lista bastante ampla, foi assumido que haveria a possibilidade de desprezar variáveis potencialmente explicativas. Variáveis ligadas à renda familiar e nível educacional não preencheram os critérios estatísticos para participar do controle simultâneo multivariado, instigando pensar que outras variáveis representativas destas dimensões sociodemográficas poderiam ter assumido valor explicativo, quando no lugar destas.

Um ponto vulnerável desta pesquisa, inerente aos estudos epidemiológicos do tipo ecológico, é a tendência em superestimar a associação estatística (Morgenstern, 2008), o que convida a ponderar o achado, no modelo ajustado, de um coeficiente de determinação $\mathrm{R}^{2}$ de 24,1\% (Tabela 4.16); embora tenha sido buscado não incorrer em "superajuste" pelo emprego de variáveis em redundância, o que poderia resultar em um $\mathrm{R}^{2}$ fictício.

Duas variáveis relacionadas à migração, "Proporção da população não natural da UF" e "Proporção da população não natural da UF, migrante nos últimos 10 anos", apresentando colinearidade original, pois uma contida na outra, foram escolhidas para a análise multivariada e embora apenas uma delas tenha restado no modelo final, as demais variáveis foram 
preservadas ou eliminadas sob influência de ambas no processo de ajuste simultâneo.

Uma ausência no estudo foi sobre a investigação de dependência espacial entre as unidades de análise. Parte da semelhança da variabilidade da taxa de detecção de hanseníase entre municípios vizinhos poderia ser imputada a fatores que não foram incluídos na análise.

Uma questão importante nos estudos ecológicos é o período de latência entre a exposição e o desfecho. Em hanseníase, o início da enfermidade pode ocorrer após um longo período de incubação, que varia de acordo com a forma clínica e alguns pacientes podem ter o diagnóstico após vários anos de manifestação dos sintomas, fazendo com que o reconhecimento da doença possa ocorrer muito tempo após a exposição. Foi assumido que a utilização de dados sociodemográficos, em maioria concernentes ao ano 2000 e a medida do desfecho realizada de 2000 a 2006, seriam adequados para representar o intervalo entre a exposição e o efeito.

Um viés ecológico que deve ser lembrado seria aquele que poderia ocorrer se a diferença da taxa para o efeito da exposição no nível individual varia de acordo com grupo, pois o risco de contrair hanseníase também depende da prevalência da doença alcançada em cada município, fato já mencionado a partir de outro enfoque.

Falta de acesso ao diagnóstico e notificações múltiplas de um mesmo caso são situações não raras em hanseníase. Migração entre os grupos, 
que costuma aumentar com o tempo de estudo, também deve ter ocorrido. Casos paucibacilares, oligossintomáticos, podem evoluir para cura espontânea, longe de qualquer registro oficial. Todos estes fatores devem ter influenciado o resultado das taxas de detecção, tendo sido admitido que estas forças tenham atuado uniformemente entre os grupos.

Mesmo com fragilidades e restrições, o delineamento ecológico mostrou-se adequado para cumprir os objetivos deste estudo, oferecendo resultados que apontaram para a importância do contexto sociodemográfico na delimitação do espaço endêmico da hanseníase, destacando-se que o fato de ter-se escolhido uma reta para representar as associações da taxa de detecção de hanseníase não significa que exista relação causal com fatores sociodemográficos, pois o que determina causalidade são os processos subjacentes ao experimento, que o levam a produzir determinado resultado e não a experiência científica por ela própria (Azevedo e Menezes, 2004).

O processo investigativo gerou perguntas sobre o conteúdo do contexto social, para o que seria importante tentar responder, para um melhor entendimento sobre como o contexto sociodemográfico afeta a saúde. Atributos individuais alcançam diferentes significados históricos e epidemiológicos a partir de múltiplas conjunturas: social, ambiental, política, cultural, econômica (Rojas, 2008). Juntamente às influências diretas do ambiente natural sobre a saúde, indivíduos são afetados pelo contexto social na medida em que se comportam em relação ao contexto ao qual estão 
inseridos; pois, como expressa Godelier (2001), "o homem não se contenta em viver em sociedade, mas necessita criar sociedade para viver". O contexto social pode ser entendido como derivado de um processo de identificação constante com o meio, gerado por indivíduos e por grupos. Neste sentido, todo contexto exibe o caráter daquilo que fundamenta ou motiva as relações sociais e que ao mesmo tempo é reproduzido quando os indivíduos as estabelecem, justamente para viverem em pertencimento a determinada sociedade, seja ao encontro de vontades pessoais ou coletivas, ou apesar delas. Mas isto não quer dizer que o contexto seja causa única ou última de algo, mas apenas que o contexto é o transcurso comum a qualquer acontecimento.

Um aspecto essencial revelado por Santos (2005) e que foi perseguido aqui, é que quando queremos elevar o espaço como categoria de análise para a definição de um lugar no qual se desenrola um fenômeno do coletivo deve-se levar em conta a interdependência e a inseparabilidade entre a materialidade, que inclui a natureza, e o seu uso, que inclui a ação humana; a isto ele chamou de "território vivo". Foi a tentativa de reconhecer este espaço, que permitiu introduzir a endemia de hanseníase no seu condicionamento social e chegar à ideia, tal qual em geografia (Gonçalves, 2004), de uma espécie de "fronteira móvel" para a delimitação temporal e espacial da endemia na área em estudo.

Municípios que almejam eliminar a hanseníase, como problema sanitário, deveriam ter os seus gestores considerando seriamente a 
possibilidade de imprimir maior cobertura das atividades assistenciais com ênfase na prevenção e fortes investimentos em vigilância à saúde, independente do patamar endêmico atual.

A proposta de um modelo epidemiológico para a hanseníase apresentado aqui deve ser vista como uma contribuição ao debate sobre o processo de difusão espacial da doença. Em vista da importância do tema em saúde coletiva, seria apreciado se o assunto continuasse despertando interesse e fossem testadas as hipóteses em jogo e abordados os aspectos polêmicos com mais profundidade; naquilo que nestas linhas foi mostrado como sendo biologicamente plausível, mas ainda permanecendo no âmbito da suposição, para que novos conhecimentos venham a esclarecer ainda mais sobre os condicionantes sociais da endemia e os meandros da transmissão. Contudo, o que fica desta parte da investigação é que para gerar hipóteses sobre o processo endêmico-epidêmico da hanseníase foi preciso ultrapassar as lacunas do imediatamente visível e violar a verdade baseada exclusivamente na demonstração; isto abriu caminho para o entendimento do que é indeterminado em um problema complexo, mas tangível pela imaginação, que sempre pode intuir e criar. 
6. Conclusões 



\section{Conclusões}

A hanseníase mostrou-se um grave problema de saúde pública para o Mato Grosso - MT e Mato Grosso do Sul - MS, inclusive com indício de alta intensidade da transmissão do $M$. leprae entre crianças e jovens. No período de 2000 a 2006, mais de 28 mil casos da doença foram diagnosticados, sendo que $67 \%$ dos municípios apresentaram níveis acima de 4,0 casos/10.000 habitantes; a maioria no MT, que alcançou taxa de detecção cerca de quatro vezes maior do que a do MS. Mediante informação aproveitável sobre incapacidades físicas no diagnóstico, em uma parcela dos municípios houve indício de que a descoberta de doença não se fez extensiva e isto pode ter prejudicado a estimativa do tamanho da endemia.

MT e MS possuem perfis demográficos diferenciados, quanto à urbanização, às migrações, ao crescimento e ao porte populacional dos municípios; com o MS mostrando-se relativamente mais urbanizado, com menor proporção da população não natural, menores diferenças de crescimento populacional e contingente demográfico mais concentrado em municípios maiores.

Uma maior proporção da população no MS, em relação ao MT, esteve morando em municípios com melhor desempenho econômico em termos de PIB municipal e em melhores condições de salubridade habitacional; mas, na dimensão médico-assistencial, a cobertura da ESF foi mais ampla no MT. 
Enquanto condicionantes sociais da endemia, o conjunto mínimo de variáveis ecológicas que se mostrou mais adequado para explicar a variabilidade das taxas de detecção da hanseníase está relacionado à aglomeração de pessoas no domicílio, cobertura da estratégia de Atenção Saúde da Família e migração. Estas variáveis mostraram associação positiva com o desfecho e em conjunto explicam $24,1 \%$ da variabilidade das taxas de detecção entre os municípios.

A aglomeração humana no domicílio pode estar traduzindo as condições socioeconômicas do grupo que reside no município, que teriam influência na espacialização da endemia, para além de processos relacionados diretamente à exposição ao $M$. leprae.

A contribuição da cobertura da ESF para conformar a taxa de detecção de hanseníase remete a concluir que alguns municípios com baixa cobertura da ESF podem não ter capturado oportunamente os casos incidentes e a endemia ali ter sido subestimada.

Foi gerada a hipótese da endemia de hanseníase comportar um processo endêmico-epidêmico de difusão; que contaria, além de ciclos longos de transmissão, com ciclos curtos, que se repetiriam na população em ondas periódicas de infecção subclínica transitória, desencadeadas pela presença de doentes bacilíferos e propagadas entre susceptíveis à infecção de porta de entrada respiratória. Indivíduos com infecção subclínica poderiam apresentar algum potencial contagiante e ao serem repetidas epidemias de infecção transitória, a partir de baixas doses de exposição ambiental, poderia haver indução de hiporresponsividade imunológica no 
nível coletivo, o que facilitaria a propagação das contaminações pelo bacilo ao longo do tempo; e, com a movimentação populacional, serem atingidos indivíduos susceptíveis à doença localizados fora do círculo de contato do doente bacilífero. $\mathrm{O}$ alcance de altos níveis de exposição ao $M$. leprae pela intensificação das transmissões, o esgotamento de susceptíveis à doença e o tratamento de bacilíferos crônicos seriam fatores contribuintes para o decaimento da endemia.

Um dos pré-requisitos para a ocupação da fronteira agrícola do MT foi o da disposição populacional para movimentar-se no território. Modificações nas formas de uso da terra, sobretudo pela tecnificação e concentração fundiária, fizeram-se ao lado de processos migratórios e de urbanização. Modernizações da estrutura produtiva têm estimulado migrações ruralurbanas, terciarização da economia e constrições na esfera do trabalho, onde uma das respostas sociais tem sido a formação de um circuito econômico de refúgio ao excedente demográfico, do campo e da cidade, abrigado em precárias condições de vida, especialmente nas periferias urbanas. Este modo de constituição do espaço tem feito emergir contextos sociodemográficos que favorecem a renovação de susceptíveis, a multiplicação de contatos e a difusão da hanseníase. 

7. Anexo 



\section{Anexo}

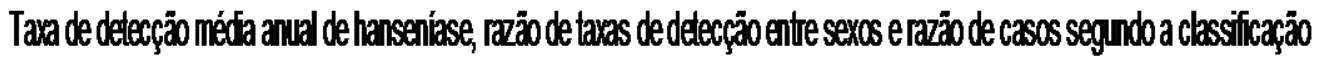
opercional da forma clíica, mricípios do Mato Grosso (MT) e Mato Grosso do SUI (MS)- 2000 a 2006

Taxa de detecegio (casos nows/ 10.000 hab./ano)

\begin{tabular}{|c|c|c|c|c|c|c|c|c|c|}
\hline \multirow{3}{*}{ Cótigo /BCE/Murićpio } & \multirow{3}{*}{ UF } & & & & & \multirow{2}{*}{\multicolumn{3}{|c|}{ Sexo }} & \multirow{3}{*}{ 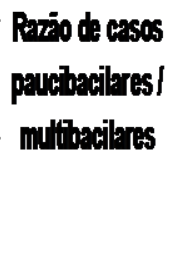 } \\
\hline & & \multicolumn{4}{|c|}{ Fava etéria } & & & & \\
\hline & & bote & $\begin{array}{l}<15 \\
\text { anos }\end{array}$ & $\begin{array}{l}16-49 \\
2105\end{array}$ & $\begin{array}{l}\text { Donos } \\
\text { ou mais }\end{array}$ & Mesculino F & mirino & $\begin{array}{l}\text { Ileselinol } \\
\text { Feminino }\end{array}$ & \\
\hline 500020 Água Clara & MS & 4,26 & 0,34 & 5,02 & 14,97 & 4,53 & 3,96 & 1,14 & 0,76 \\
\hline 500025 Acinópois & MS & 244 & 0,00 & 2,65 & 7,33 & 1,82 & 3,15 & 0,58 & 1,50 \\
\hline 500060 Amambai & MS & 1,96 & 0,28 & 1,80 & 6,58 & 260 & 1,32 & 1,98 & 0,62 \\
\hline 500070 Anastácio & MS & 3,26 & 0,00 & 3,38 & 9,02 & 4,48 & 1,99 & 225 & 1,12 \\
\hline 500080 Anauriàndia & MS & 1,75 & 1,11 & 1,65 & 3,37 & 3,04 & 0,36 & 8,36 & 0,25 \\
\hline 500085 Angélica & MS & 4,35 & 1,43 & 5,55 & 5,54 & 4,48 & 4,21 & 1,06 & 2,00 \\
\hline 500090 Antổnio Joäo & MS & 0,93 & 0,00 & 0,38 & 4,97 & 0,74 & 1,14 & 0,65 & 0,00 \\
\hline 500100 Aparecida do Taboado & MS & 3,61 & 0,81 & 3,69 & 7,40 & 3,55 & 3,67 & 0,97 & 0,23 \\
\hline 500110 Aquidauana & MS & 1,85 & 0,41 & 2,08 & $3, \pi$ & 2,42 & 1,28 & 1,89 & 0,73 \\
\hline 500124 Aal Mroréa & MS & 266 & 0,00 & 2,15 & 11,47 & 3,80 & 1,46 & 261 & 0,07 \\
\hline 500150 Bandeirantes & MS & 220 & 0,00 & 1,25 & 9,08 & 1,65 & 281 & 0,59 & 0,25 \\
\hline 500190 Bataguassu & MS & 202 & 0,26 & 2,60 & 3,71 & 2,50 & 1,51 & 1,66 & 1,67 \\
\hline 500200 Batayporä & MS & 1,62 & 0,00 & 1,89 & 3,97 & 2,19 & 1,02 & 2,14 & 0,44 \\
\hline 500210 Bela Vista & MS & 1,46 & 0,19 & 1,48 & 4,17 & 1,98 & 0,91 & 219 & 0,64 \\
\hline 500215 Bodoquena & MS & 5,58 & 0,98 & 5,47 & 18,20 & 6,71 & 4,31 & 1,55 & 0,83 \\
\hline 500220 Bonito & MS & 4,03 & 0,26 & 4,35 & 11,75 & 3,50 & 4,58 & 0,76 & 0,63 \\
\hline 500230 Brasiânda & MS & 4,93 & 0,73 & 4,93 & 15,66 & 6,36 & 3,37 & 1,89 & 0,83 \\
\hline 500240 Сазаро & MS & 227 & 0,00 & $1, \pi$ & 8,96 & 269 & 1,84 & 1,46 & 0,24 \\
\hline 500260 Camapuã & MS & 3,84 & 0,28 & 4,67 & 7,93 & 4,06 & 3,60 & 1,13 & 1,65 \\
\hline 500270 Campo Grande & MS & 206 & 0,20 & 2,00 & 5,96 & 2,43 & 1,72 & 1,41 & 1,03 \\
\hline 500280 Caracd & MS & 238 & 0,00 & 2,94 & 5,87 & 281 & 1,90 & 1,48 & 0,14 \\
\hline 500290 Cassilànda & MS & 297 & 0,26 & 2,66 & 7,52 & 3,44 & 236 & 1,46 & 0,65 \\
\hline 500295 Chapadtao do Sul & MS & 0,95 & 0,00 & 1,23 & 269 & 0,80 & 1,12 & 0,72 & 1,25 \\
\hline 500310 Corguinho & MS & 200 & 0,00 & 3,03 & 2,43 & 298 & 0,87 & 3,44 & 1,50 \\
\hline 500315 Coronel Sapucaia & MS & 293 & 0,56 & 4,34 & 4,78 & 4,49 & 1,32 & 3,41 & 0,30 \\
\hline 500320 Coumbá & MS & 4,46 & 1,17 & 5,68 & 7,80 & 4,36 & 4,57 & 0,95 & 206 \\
\hline
\end{tabular}




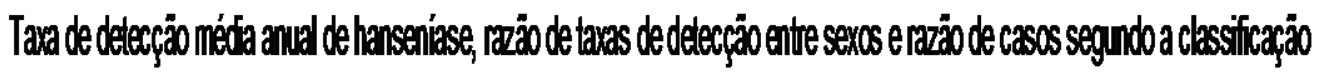

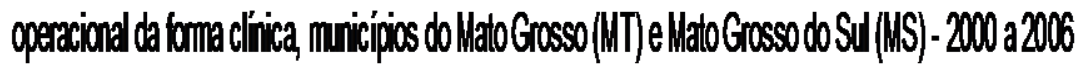

\begin{tabular}{|c|c|c|c|c|c|c|c|c|c|}
\hline \multirow{3}{*}{ Cótgo/BGEINurićpio } & \multirow{3}{*}{ UF } & \multicolumn{7}{|c|}{ Taxa de detectyio (casos nows/ 10.000 hab./ano) } & \multirow{3}{*}{ 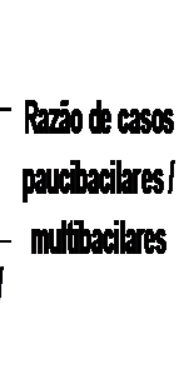 } \\
\hline & & \multirow{2}{*}{$\begin{array}{l}\text { Gerel } \\
\text { both }\end{array}$} & \multicolumn{3}{|c|}{ Faxa téria } & \multicolumn{3}{|c|}{ Sexo } & \\
\hline & & & $\begin{array}{l}<15 \\
\text { anos }\end{array}$ & $\begin{array}{l}15-49 \\
2105\end{array}$ & $\begin{array}{l}50 \text { anos } \\
\text { ou mais }\end{array}$ & Mascellino Fe & mirino & $\begin{array}{l}\text { Massulinol } \\
\text { Fenninio }\end{array}$ & \\
\hline 500325 Costa Rica & MS & 1,88 & 0,30 & 2,08 & 4,55 & 206 & 1,69 & 1,2 & 0,50 \\
\hline 500330 Coxim & MS & 6,18 & 0,88 & 6,51 & 15,91 & 8,37 & 3,91 & 214 & 1,18 \\
\hline 500345 Deodápois & MS & 3,23 & 0,00 & 3,82 & 6,49 & 3,73 & 272 & 1,37 & 0,60 \\
\hline 500348 Dasismäos do Buiti & MS & 3,00 & 0,00 & 2,70 & 11,29 & 285 & 3,18 & 0,90 & 1,22 \\
\hline 500350 Douradina & MS & 1,51 & 0,00 & 1,75 & 3,56 & 1,77 & 1,23 & 1,44 & 4,00 \\
\hline 500370 Dourados & MS & 260 & 0,22 & 2,78 & 7,12 & 288 & 229 & 1,25 & 1,98 \\
\hline 500375 Bdorado & MS & 245 & 0,00 & 3,42 & 4,26 & 4,09 & 0,78 & 5,24 & 0,27 \\
\hline 500380 Fätima do Sul & MS & 3,30 & 0,00 & 3,49 & 7,27 & 3,17 & 3,42 & 0,93 & 0,68 \\
\hline 500400 Gtória de Dourados & MS & 1,06 & 0,00 & 1,14 & 225 & 2,12 & 0,00 & _ & 0,17 \\
\hline 500410 Guia Lopes da Laguna & MS & 1,71 & 0,00 & 2,39 & 282 & 1,67 & 1,74 & 0,96 & 0,40 \\
\hline 500430 Iguaterni & MS & 218 & 0,29 & 1,86 & 8,02 & 1,97 & 241 & 0,82 & 267 \\
\hline 500440 /nocencia & MS & 1,73 & 0,00 & 1,56 & 6,08 & 260 & 0,73 & 3,59 & 0,25 \\
\hline 500450 ltepopĩ & MS & 1,73 & 0,00 & 2,03 & 4,10 & 200 & 1,34 & 1,56 & 1,86 \\
\hline 5004000 tequirá & MS & 284 & 0,25 & 3,42 & 7,51 & 3,11 & 254 & 1,22 & 0,65 \\
\hline 500470 kinhema & MS & 1,57 & 0,00 & 1,38 & 4,75 & 228 & 0,83 & 275 & 0,47 \\
\hline 500400 Japora & MS & 0,65 & 0,51 & 0,00 & 3,45 & 0,82 & 0,45 & 1,83 & 0,00 \\
\hline 500490 taraguai & MS & 0,76 & 0,00 & 0,48 & 271 & 1,38 & 0,00 & - & 0,50 \\
\hline 500500 tarorim & MS & 273 & 0,38 & 3,45 & 5,06 & 291 & 2,55 & 1,14 & 0,73 \\
\hline 500510 batei & MS & 1,14 & 0,00 & 0,00 & 7,67 & 0,72 & 1,59 & 0,46 & 0,50 \\
\hline 500515 dut & MS & 0,88 & 0,00 & 0,60 & 3,48 & 1,16 & 0,59 & 1,96 & 200 \\
\hline 500520 Ladánio & MS & 4,63 & 247 & 5,57 & 6,81 & 3,09 & 6,23 & 0,50 & 2,31 \\
\hline 500525 Laguna Caарä & MS & 0,98 & 0,00 & 0,47 & 5,68 & 1,43 & 0,51 & 282 & 3,00 \\
\hline 500540 Mracail & MS & 3,15 & 1,09 & 3,50 & 7,25 & 3,00 & 3,30 & 0,91 & 200 \\
\hline 505560 Mranda & MS & 3,11 & 0,71 & 3,31 & 8,16 & 3,57 & 261 & 1,37 & 0,70 \\
\hline 500568 Mundo Nowo & MS & 4,01 & 0,32 & 3,78 & 11,06 & 5,42 & 2603 & 206 & 0,40 \\
\hline 500570 Nariá & MS & 1220 & 3,67 & 13,13 & 28,74 & 11,63 & 1278 & 0,91 & 1,63 \\
\hline
\end{tabular}




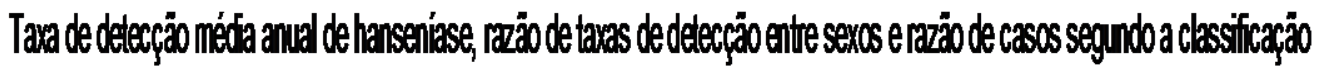

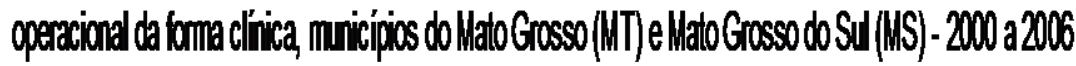

\begin{tabular}{|c|c|c|c|c|c|c|c|c|c|}
\hline \multirow{3}{*}{ Cótgo |BCE / Iuricipio } & \multicolumn{8}{|c|}{ Taxa de detectio (casos nows/ 10.000 hab./ano) } & \multirow{3}{*}{ 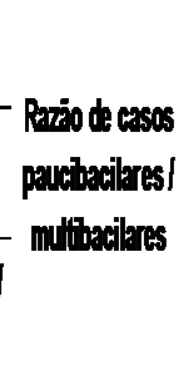 } \\
\hline & \multirow[t]{2}{*}{ UF } & & \multicolumn{3}{|c|}{ Faxa etéria } & \multicolumn{3}{|c|}{ Sexo } & \\
\hline & & & $\begin{array}{l}<15 \\
2105\end{array}$ & $\begin{array}{l}15-9 \\
\text { anos }\end{array}$ & $\begin{array}{l}50 \text { anos } \\
\text { ou mais }\end{array}$ & Mascellion Fen & mirimo & $\begin{array}{l}\text { Ilasculinol } \\
\text { Fennino }\end{array}$ & \\
\hline 500580 Noaque & MS & 1,75 & 0,00 & 1,49 & 7,14 & 215 & 1,30 & 1,65 & 1,22 \\
\hline 500600 Nova Alworda do SUl & MS & 2,52 & 0,00 & 3,08 & 7,38 & 2,56 & 247 & 1,03 & 0,80 \\
\hline 500620 Nova Andradina & MS & 3,20 & 0,40 & 3,81 & 6,48 & 4,09 & 231 & 1,7 & 0,89 \\
\hline 500625 Novo Horizonted do Sul & MS & 224 & 0,74 & 2,36 & 5,57 & 284 & 1,57 & 1,80 & 0,13 \\
\hline 500630 Paranaba & MS & 5,58 & 0,53 & 6,13 & 11,78 & 5,32 & 5,85 & 0,91 & 0,42 \\
\hline 500635 Paranhos & MS & 274 & 0,68 & 3,19 & 7,70 & 3,46 & 1,97 & 1,76 & 0,25 \\
\hline 500640 Petro Games & MS & 7,48 & 1,63 & 8,83 & 13,85 & 8,29 & 6,59 & 1,26 & 1,37 \\
\hline 500660 Ponta Porä & MS & 1,70 & 0,13 & 1,93 & 4,93 & 248 & 0,93 & 266 & 0,21 \\
\hline 500600 Poto Murtinho & MS & 1,91 & 0,00 & 2,96 & 3,30 & 239 & 1,36 & 1,76 & 0,38 \\
\hline 500710 Rhas do Rio Pardo & MS & 0,97 & 0,00 & 1,14 & 3,04 & 1,34 & 0,53 & 2,54 & 0,83 \\
\hline 500720 Rio Bihante & MS & 272 & 0,17 & 3,35 & 6,91 & 294 & 249 & 1,18 & 1,14 \\
\hline 500730 Rio Negro & MS & 3,45 & 0,00 & 2,52 & 10,96 & 5,54 & 1,12 & 4,94 & 0,09 \\
\hline 500740 Rio Verde de Mato Grosso & MS & 3,82 & 0,50 & 3,72 & 10,68 & 4,60 & 291 & 1,61 & 0,67 \\
\hline 500750 Rochedo & MS & 217 & 0,00 & 2,96 & 3,68 & 288 & 1,34 & 215 & 0,75 \\
\hline 500755 Santa Rita do Pardo & MS & 1,84 & 0,00 & 2,69 & 3,06 & 270 & 0,87 & 3,10 & 1,25 \\
\hline 500769 Sżo Gabriel do Oeste & MS & 219 & 0,25 & 2,19 & 7,49 & 3,19 & 1,13 & 283 & 0,87 \\
\hline 500770 Sete Quedas & MS & 206 & 0,46 & 2,31 & 4,43 & 1,44 & 272 & 0,53 & 0,08 \\
\hline 500780 Sethina & MS & 0,00 & 0,00 & 0,00 & 0,00 & 0,00 & 0,00 & - & \\
\hline 500790 Siddànda & MS & 292 & 0,33 & 3,27 & 8,55 & 3,30 & 2,52 & 1,31 & 1,30 \\
\hline 500793 Sonora & MS & 6,16 & 0,00 & 7,58 & 21,23 & 7,18 & 5,04 & 1,42 & 1,00 \\
\hline 500795 Taxun & MS & 3,11 & 0,41 & 3,80 & 8,76 & 268 & 3,59 & 0,75 & 0,33 \\
\hline 500797 Taquansss & MS & 1,80 & 0,00 & 2,51 & 245 & 256 & 0,96 & 267 & 1,00 \\
\hline 500000 Terenos & MS & 1,64 & 0,00 & 1,56 & 5,20 & 200 & 1,24 & 1,02 & 0,56 \\
\hline 500830 Très Lagcas & MS & 4,54 & 0,85 & 4,91 & 9,71 & 5,03 & 4,06 & 1,24 & 1,53 \\
\hline 500840 Vicentina & MS & 295 & 0,00 & 3,03 & 6,13 & 212 & 3,82 & 0,56 & 0,57 \\
\hline
\end{tabular}




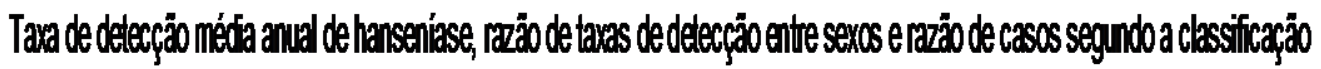

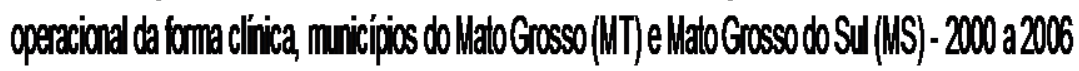

\begin{tabular}{|c|c|c|c|c|c|c|c|c|c|}
\hline \multirow{3}{*}{ Cótgo/BGE/Iuricipio } & \multirow{3}{*}{ UF } & \multicolumn{7}{|c|}{ Taxa de detectyio (casos nowos/ 10.000 hab./ano) } & \multirow{3}{*}{$\begin{array}{l}\text { - Rario de cascos } \\
\text { pauchacilaresi } \\
\text { - muthexilares }\end{array}$} \\
\hline & & \multirow{2}{*}{$\begin{array}{l}\text { Geral } \\
\text { butp }\end{array}$} & \multicolumn{3}{|c|}{ Faixa etéria } & \multicolumn{3}{|c|}{ Sexo } & \\
\hline & & & $\begin{array}{l}<15 \\
a n 0 s\end{array}$ & $\begin{array}{l}15-49 \\
\text { anos }\end{array}$ & $\begin{array}{l}50 \text { anos } \\
\text { ou meis }\end{array}$ & Mascalino & minino & $\begin{array}{l}\text { Massulinol } \\
\text { Fenninoto }\end{array}$ & \\
\hline 510010 Acorizal & M & 5,26 & 0,00 & 6,33 & 11,70 & 4,82 & 5,80 & 0,83 & 1,20 \\
\hline 510020 Água Bca & MT & 2,49 & 3,99 & 28,78 & 4275 & 28,68 & 15,83 & 1,81 & 0,58 \\
\hline 510025 Ata Forecta & MT & 16,28 & 3,24 & 19,71 & 35,51 & 16,89 & 15,51 & 1,09 & 0,89 \\
\hline 510030 Ato Araguara & MT & 8,00 & 0,00 & 9,33 & 17,13 & 9,51 & 6,38 & 1,49 & 0,38 \\
\hline 510035 Atto Boa Vista & MT & 24,19 & 4,34 & 25,97 & 76,95 & 27,89 & 20,04 & 1,39 & 1,13 \\
\hline 510040 Ato Garças & MT & 10,79 & 1,23 & 12,96 & 19,47 & 14,94 & 6,37 & 235 & 1,33 \\
\hline 510050 Alto Paraguai & MT & 21,63 & 8,34 & 26,35 & 33,20 & 31,10 & 11,04 & 282 & 0,81 \\
\hline 510000 Ato Taquai & MT & 261 & 0,00 & 4,01 & 3,32 & 222 & 3,05 & 0,73 & 200 \\
\hline 510080 Apiacás & MT & 19,70 & 3,21 & 21,93 & 63,54 & 25,13 & 12,62 & 1,99 & 0,96 \\
\hline 510100 Araguaima & MT & 28,31 & 13,71 & 27,11 & 63,75 & 31,14 & 25,22 & 1,23 & 1,19 \\
\hline 510120 Aaguainha & MT & 1,07 & 0,00 & 0,00 & 5,45 & 200 & 0,00 & - & - \\
\hline 510125 Aaputanga & MT & 18,75 & 0,97 & 23,73 & 42,17 & 18,64 & 18,86 & 0,99 & 7,76 \\
\hline 510130 Arenápois & MT & 15,45 & 3,27 & 18,63 & 30,89 & 18,86 & 11,81 & 1,00 & 2,31 \\
\hline 510140 Aipumã & MT & 8,94 & 0,78 & 10,94 & 25,59 & 10,81 & 6,64 & 1,63 & 1,27 \\
\hline 510160 Bapäo de Melgaço & MT & 5,91 & 0,00 & 8,30 & 10,08 & 8,37 & 3,07 & 273 & 1,07 \\
\hline 510170 Bara do Buges & MT & 16,25 & 264 & 20,96 & 34,79 & 18,92 & 13,37 & 1,42 & 1,13 \\
\hline 510180 Bara do Garças & MT & 2,69 & 6,46 & 25,68 & 46,76 & 23,60 & 21,78 & 1,08 & 0,23 \\
\hline 510190 Brasnate & MT & 13,21 & 1,86 & 18,91 & 21,84 & 15,32 & 10,76 & 1,42 & 1,06 \\
\hline 510250 Cáceres & MT & 12,13 & 1,92 & 14,61 & 26,84 & 13,95 & 10,23 & 1,36 & 2,87 \\
\hline 510260 Campinápdis & MT & 13,94 & 3,04 & 18,46 & 28,98 & 16,73 & 10,82 & 1,55 & 0,56 \\
\hline 510263 Campo Now do Parecis & MT & 14,18 & 3,48 & 18,20 & 30,73 & 16,20 & 11,02 & 1,39 & 1,99 \\
\hline 510207 Campo Verde & MT & 11,12 & 211 & 12,65 & 34,40 & 12,96 & 8,96 & 1,45 & 1,16 \\
\hline 510268 Campos de Júlio & MT & 7,83 & 1,24 & 10,85 & 13,54 & 9,85 & 5,41 & 1,82 & 1,00 \\
\hline 510269 Canabrava do Note & MT & 13,95 & 3,55 & 18,46 & 25,21 & 17,52 & 9,58 & 1,83 & 0,57 \\
\hline 510270 Canarana & MT & 20,87 & 3,45 & 27,48 & 42,35 & 23,46 & 18,13 & 1,29 & 228 \\
\hline 510279 Calinda & MT & 6,65 & 0,79 & 8,22 & 14,40 & 8,67 & 4,27 & 203 & 1,13 \\
\hline
\end{tabular}




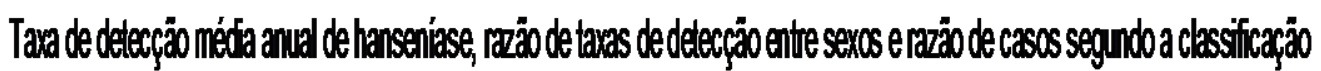

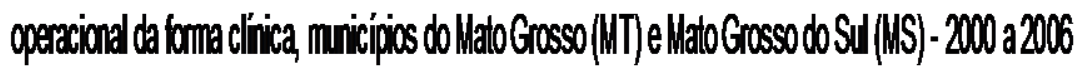

\begin{tabular}{|c|c|c|c|c|c|c|c|c|c|}
\hline \multirow{3}{*}{ Cótigo BBGE/Muriépio } & \multicolumn{8}{|c|}{ Taxa de detectegio (casos nowos/ 10.000 habl.ano) } & \multirow{3}{*}{ 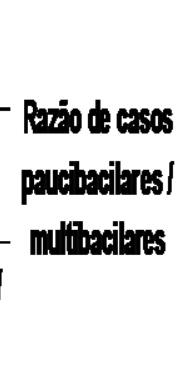 } \\
\hline & \multirow[t]{2}{*}{ Uf } & \multirow{2}{*}{$\begin{array}{l}\text { Gerd } \\
\text { brath }\end{array}$} & \multicolumn{3}{|c|}{ Faxice etria } & \multicolumn{3}{|c|}{ Sero } & \\
\hline & & & $\begin{array}{l}<15 \\
\text { ans }\end{array}$ & $\begin{array}{l}15+19 \\
\text { ans }\end{array}$ & $\begin{array}{l}50 \text { anos } \\
\text { ou meis }\end{array}$ & Mlasculino Fem & minino & $\begin{array}{l}\text { Ilescelinol } \\
\text { Feminino }\end{array}$ & \\
\hline 510285 Castanheria & MT & 8,85 & 234 & 11,36 & 14,94 & 9,42 & 7,80 & 1,21 & 1,4 \\
\hline 510300 Chepada dos Guimarees & MT & 14,49 & 285 & 16,58 & 33,76 & 14,12 & 14,89 & 0,95 & \\
\hline 510305 Cáudia & MT & 5,18 & 0,00 & 7,85 & 8,18 & 4,50 & 5,55 & 0,6 & 6 \\
\hline 510310 Cocalinho & MT & 7,72 & 0,00 & 9,38 & 20,84 & 11,61 & 3,38 & 3,43 & 0,5 \\
\hline 510320 Calider & MT & 6,18 & 0,53 & 6,28 & $16, \pi$ & 6,87 & 5,45 & 1,26 & \\
\hline 510330 Comodaro & MT & 6,92 & 1,18 & 8,78 & 17,28 & 7,86 & 5,88 & 1,34 & \\
\hline 510335 Confresa & MT & 14,65 & 4,52 & 17,90 & 30,71 & 17,17 & 11,61 & 1,48 & 0 \\
\hline 510337 Catigyuagy & MT & 9,68 & 1,51 & 12,58 & 24,56 & 10,70 & 8,41 & 1,27 & \\
\hline 510340 Cuiabá & MT & 10,19 & 3,86 & 11,10 & 21,01 & 11,40 & 9,04 & 1,26 & 1 \\
\hline 510345 Denise & MT & 11,18 & 3,46 & 14,92 & 17,40 & 11,65 & 10,67 & 1,09 & \\
\hline 510350 Damantino & MT & 41,29 & 4,21 & 46,23 & 123,35 & 43,70 & 38,71 & 1,13 & 0,3 \\
\hline 510360 Dam Aquino & MT & 9,11 & 294 & 9,88 & 16,62 & 11,03 & 7,07 & 1,56 & \\
\hline 510370 Féz Natal & MT & 14,77 & 3,86 & 19,97 & 34,16 & 17,37 & 11,60 & 1,50 & \\
\hline 510380 Figuerípodis DOeste & MT & 7,54 & 0,00 & 9,39 & 15,63 & 9,63 & 5,26 & 1,83 & 1,2 \\
\hline 510385 Gaicha do Note & MT & 5,11 & 237 & 6,43 & 7,69 & 4,15 & 6,28 & 0,66 & 1,0 \\
\hline 510390 General Cameiro & MT & 5,25 & 0,00 & 6,38 & 1289 & 6,00 & 3,4 & 201 & 0,2 \\
\hline 5103955 Gória DOeste & MT & 7,57 & 0,00 & 11,32 & 8,29 & 10,80 & 3,99 & 271 & 3,0 \\
\hline 51040 Guarantä do Note & MT & 11,32 & 1,65 & 14,43 & 25,97 & 11,48 & 11,15 & 1,03 & 1,5 \\
\hline 510220 Gurdinga & MT & 16,56 & 7,98 & 20,68 & 18,06 & 18,06 & 1476 & 1,22 & 3,7 \\
\hline 510450 Indará & MT & 17,33 & 0,00 & 2,00 & 34,84 & 21,38 & 1296 & 1,65 & 1,6 \\
\hline 510455 traiba & MT & 16,45 & 0,67 & 23,80 & 31,42 & 18,12 & 14,55 & 1,25 & 1,0 \\
\hline 510400 Higivira & MT & 284 & 0,00 & 4,43 & 3,03 & 3,37 & 223 & 1,51 & 1,36 \\
\hline 510480 daciara & MT & 9,87 & 1,75 & 12,32 & 17,02 & 11,04 & 8,59 & 1,29 & 0,86 \\
\hline 510490 bangada & MT & 8,14 & 1,96 & 11,93 & 11,71 & 10,92 & 5,06 & 216 & 0,6 \\
\hline 51050 baun & MT & 6,23 & 0,07 & 7,83 & 13,47 & 8,86 & 3,48 & 255 & 0,83 \\
\hline 510510 duara & MT & 21,77 & 4,23 & 27,29 & 44,61 & 24,75 & 18,48 & 1,34 & 1,30 \\
\hline
\end{tabular}




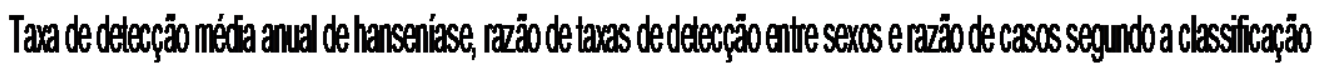
opercional da forma cl'rica, muicipios do Mato Grosso(MT) e Mato Grosso do Su (MS) - 2000 a 2006

\begin{tabular}{|c|c|c|c|c|c|c|c|c|c|}
\hline \multirow{3}{*}{ Cótgo /PGE/Lurićpio } & \multirow{3}{*}{ UF } & \multicolumn{7}{|c|}{ Taxa de deteactio (casos nowos/ 10.000 hab.lano) } & \multirow{3}{*}{ 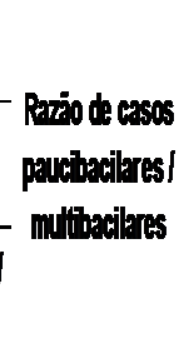 } \\
\hline & & \multirow{2}{*}{$\begin{array}{l}\text { Gerel } \\
\text { both }\end{array}$} & \multicolumn{3}{|c|}{ Faiva etria } & \multicolumn{3}{|c|}{ Sexo } & \\
\hline & & & $\begin{array}{l}<15 \\
2105\end{array}$ & $\begin{array}{l}15-49 \\
\text { anos }\end{array}$ & $\begin{array}{l}50 \text { anos } \\
\text { ou mais }\end{array}$ & Mesculino I & mirino & $\begin{array}{l}\text { Masedinol } \\
\text { Femirion }\end{array}$ & \\
\hline 510515 Juína & MT & 11,38 & 2,49 & 13,76 & 25,22 & 11,98 & 10,65 & 1,12 & 1,52 \\
\hline 510517 Junuena & MT & 12,53 & 0,67 & 14,67 & 42,57 & 14,68 & 10,09 & 1,45 & 0,63 \\
\hline 510520 ussimera & MT & 7,83 & 1,90 & 8,68 & 15,89 & 8,76 & 6,80 & 1,29 & 1,13 \\
\hline 510523 Lambai D'Oeste & MT & 11,27 & 3,17 & 13,95 & 19,81 & 11,57 & 10,93 & 1,06 & 3,13 \\
\hline 510525 Lueas do Rio Verde & MT & 8,50 & 1,91 & 11,16 & 15,15 & 9,35 & 7,55 & 1,24 & 0,57 \\
\hline 510530 Lucära & MT & 15,47 & 4,92 & 23,02 & 17,86 & 13,07 & 18,08 & 0,72 & 213 \\
\hline 510550 Vila Bela da Santissima Trindade & MT & 5,05 & 0,85 & 7,10 & 9,39 & 6,05 & 3,88 & 1,56 & 1,37 \\
\hline 510558 Macekânda & MT & 19,50 & 6,62 & 24,71 & 41,01 & 23,90 & 14,35 & 1,67 & 1,24 \\
\hline 510560M Maupá & MT & 18,32 & 247 & 23,43 & 44,31 & 24,02 & 11,23 & 2,19 & 0,60 \\
\hline 510562 Mrassol dOeste & MT & 17,05 & 1,67 & 19,65 & 39,63 & 20,24 & 13,82 & 1,46 & 1,79 \\
\hline 510590 Notres & MT & 16,86 & 298 & 19,87 & 40,78 & 19,53 & 13,98 & 1,40 & 1,69 \\
\hline 510600 Natetetinda & MT & 16,13 & 7,47 & 16,62 & 34,09 & 15,21 & 16,65 & 0,91 & 0,80 \\
\hline 510610 Nossa Senhora do Livamento & MT & 7,79 & 4,49 & 7,29 & 14,53 & 8,96 & 6,41 & 1,40 & 1,06 \\
\hline 510615 Nora Banderiantes & MT & 6,67 & 206 & 7,82 & 14,62 & 9,56 & 285 & 3,35 & 0,80 \\
\hline 510617 Nova Nazaré & MT & 6,48 & 5,40 & 7,74 & 5,35 & 9,71 & 299 & 3,25 & 200 \\
\hline 510620 Nova Brasilandia & MT & 32,93 & 6,48 & 41,45 & 62,83 & 38,71 & 26,23 & 1,48 & 0,91 \\
\hline 510621 Nova Canä do Note & MT & 7,08 & 1,16 & 8,11 & 16,78 & 7,22 & 6,90 & 1,05 & 0,75 \\
\hline 510622 Nova Mutum & MT & 11,30 & 0,78 & 13,14 & 44,39 & 12,37 & 10,09 & 1,23 & 1,57 \\
\hline 510623 Nova Olimpia & MT & 8,96 & 1,17 & 12,13 & 23,00 & 11,88 & 5,80 & 2,05 & 1,29 \\
\hline 510624 Nova Ubirdä & MT & 6,79 & 0,65 & 8,60 & 19,61 & 9,41 & 3,14 & 3,00 & 0,72 \\
\hline 510625 Nova Xavantina & MT & 21,00 & 7,51 & 25,56 & 31,78 & 22,37 & 19,55 & 1,14 & 0,80 \\
\hline 510626 Noro Mundo & MT & 8,63 & $0, \pi$ & 8,69 & 30,96 & 11,06 & 5,36 & 206 & 1,13 \\
\hline 510627 Noyo Horizonte do Nate & MT & 19,18 & 5,40 & 26,99 & 21,77 & 16,58 & 2,06 & 0,75 & 1,93 \\
\hline 510028 Novo Säo Joaquim & MT & 1209 & 0,55 & 15,27 & 27,36 & 15,75 & 7,71 & 204 & 1,30 \\
\hline 510629 Paranaita & MT & 5,62 & 0,89 & 7,00 & 12,60 & 5,21 & 6,10 & 0,85 & 0,81 \\
\hline 510630 Paranatinga & MT & 21,78 & 4,65 & 28,07 & 40,59 & 25,85 & 17,07 & 1,51 & 204 \\
\hline
\end{tabular}




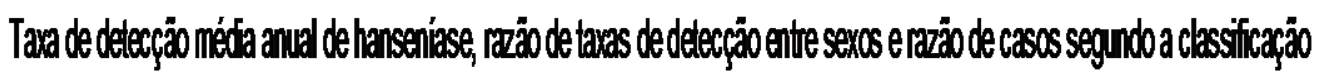

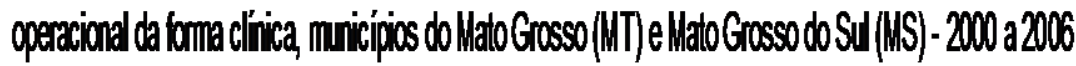

\begin{tabular}{|c|c|c|c|c|c|c|c|c|c|}
\hline \multirow{3}{*}{ Cótgo BBGE/Lurípio } & \multirow{3}{*}{ UF } & \multicolumn{7}{|c|}{ Taxa de detectiog (casos nows/ 10.000 hablano) } & \multirow{3}{*}{$\begin{array}{l}\text { - Razio de casos } \\
\text { pauchecileres I } \\
\text { - mithecilares }\end{array}$} \\
\hline & & \multirow{2}{*}{$\begin{array}{l}\text { Gere } \\
\text { bonte }\end{array}$} & \multicolumn{3}{|c|}{ Faxa déria } & \multicolumn{3}{|c|}{ Sexo } & \\
\hline & & & $\begin{array}{l}<15 \\
\operatorname{ancs}\end{array}$ & $\begin{array}{l}1549 \\
2105\end{array}$ & $\begin{array}{l}5 \text { Danos } \\
\text { ou mais }\end{array}$ & Mascalino F & emirino & $\begin{array}{l}\text { |lassulinol } \\
\text { Feminion }\end{array}$ & \\
\hline 510637 Peta Preta & MT & 19,32 & 231 & 2,65 & 42,90 & 20,82 & 17,68 & 1,18 & 1,72 \\
\hline 510642 Pexdo de Azeredo & MT & 28,83 & 9,48 & 36,36 & 63,15 & 32,52 & 24,77 & 1,31 & 0,67 \\
\hline 510645 Planalo da Serra & MT & 6,85 & 0,00 & 8,16 & 17,95 & 9,16 & 4,20 & 218 & 0,44 \\
\hline 510650 Poconé & MT & 8,60 & 244 & 9,76 & 18,40 & 10,78 & 6,20 & 1,74 & 0,58 \\
\hline 510665 Pontal do Araguara & MT & 16,49 & 3,68 & 19,51 & 30,50 & 17,28 & 15,68 & 1,10 & 0,42 \\
\hline 510670 Ponte Branca & MT & 7,05 & 2,58 & 7,89 & 11,10 & 8,01 & 5,98 & 1,34 & 0,25 \\
\hline 510675 Pontese Lacercta & MT & 14,07 & 2,92 & 17,00 & 31,37 & 15,99 & 12,03 & 1,33 & 292 \\
\hline 510677 Poto Alegre do Nate & MT & 17,99 & 226 & 24,09 & 36,76 & 24,20 & 10,75 & 225 & 0,69 \\
\hline 510680 Poto dos Gauchos & MT & 1207 & 212 & 12,01 & 41,53 & 14,84 & 8,99 & 1,65 & 0,55 \\
\hline 510682 Poto Esperidäo & MT & 6,71 & 0,39 & 9,45 & 13,23 & 7,88 & 5,34 & 1,48 & 0,44 \\
\hline 510685 Poto Estrela & MT & 25,99 & 5,39 & 33,16 & 50,52 & 28,05 & 23,71 & 1,18 & 200 \\
\hline 510700 Poxoréo & MT & 13,80 & 3,44 & 15,67 & 26,02 & 16,07 & 11,15 & 1,44 & 1,30 \\
\hline 510704 Pimavera do Leste & MT & 8,29 & 1,49 & 10,45 & 19,13 & 9,47 & 7,02 & 1,35 & 0,99 \\
\hline 510706 Querencia & M & 11,31 & 3,35 & 13,18 & 31,53 & 13,13 & 9,14 & 1,44 & 1,96 \\
\hline 510710 Säo José dos Quato Marcos & MT & 10,99 & 0,78 & 13,46 & 21,30 & 1274 & 9,18 & 1,39 & 1,79 \\
\hline 510715 Reserva do Cabaça & MT & 15,59 & 215 & 20,87 & 24,56 & 13,09 & 18,28 & 0,72 & 3,60 \\
\hline 510718 Riberiöoascahera & MT & 16,64 & 4,81 & 19,65 & 33,15 & 20,09 & 1270 & 1,58 & 0,64 \\
\hline 510719 Rherïorinho & M & 19,26 & 6,75 & 21,85 & 33,71 & 19,43 & 19,08 & 1,02 & 0,21 \\
\hline 510720 Rio Branco & M & 28,33 & 3,92 & $32, \pi$ & 57,70 & 31,71 & 24,86 & 1,28 & 3,85 \\
\hline 510724 Santa Camem & MT & 23,58 & 4,19 & 30,31 & 5278 & 27,91 & 18,38 & 1,52 & 0,67 \\
\hline 510726 Santo Afonso & MT & 16,95 & 0,00 & 20,34 & 45,71 & 19,10 & 14,45 & 1,32 & 1,13 \\
\hline 510729 São Josédo Powo & MT & 9,23 & 3,41 & 12,20 & 9,28 & 8,51 & 10,10 & 0,84 & 1,22 \\
\hline 510730 São Josédo Rio Claro & MT & 19,76 & 5,31 & 25,12 & 38,20 & 21,44 & 17,00 & 1,20 & 1,82 \\
\hline 510735 São Josédo Xingu & MT & 14,09 & 286 & 16,71 & 40,28 & 13,92 & 14,31 & 0,97 & 256 \\
\hline 510740 Säo Petro da Oipa & MT & 20,52 & 5,19 & 25,56 & 33,83 & 21,41 & 19,52 & 1,10 & 0,96 \\
\hline 510760 Randanópols & MT & 12,28 & 3,25 & 14,34 & 23,73 & 13,75 & 10,78 & 1,28 & 1,32 \\
\hline
\end{tabular}




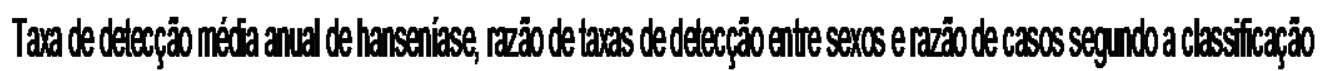

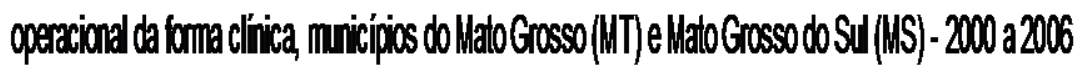

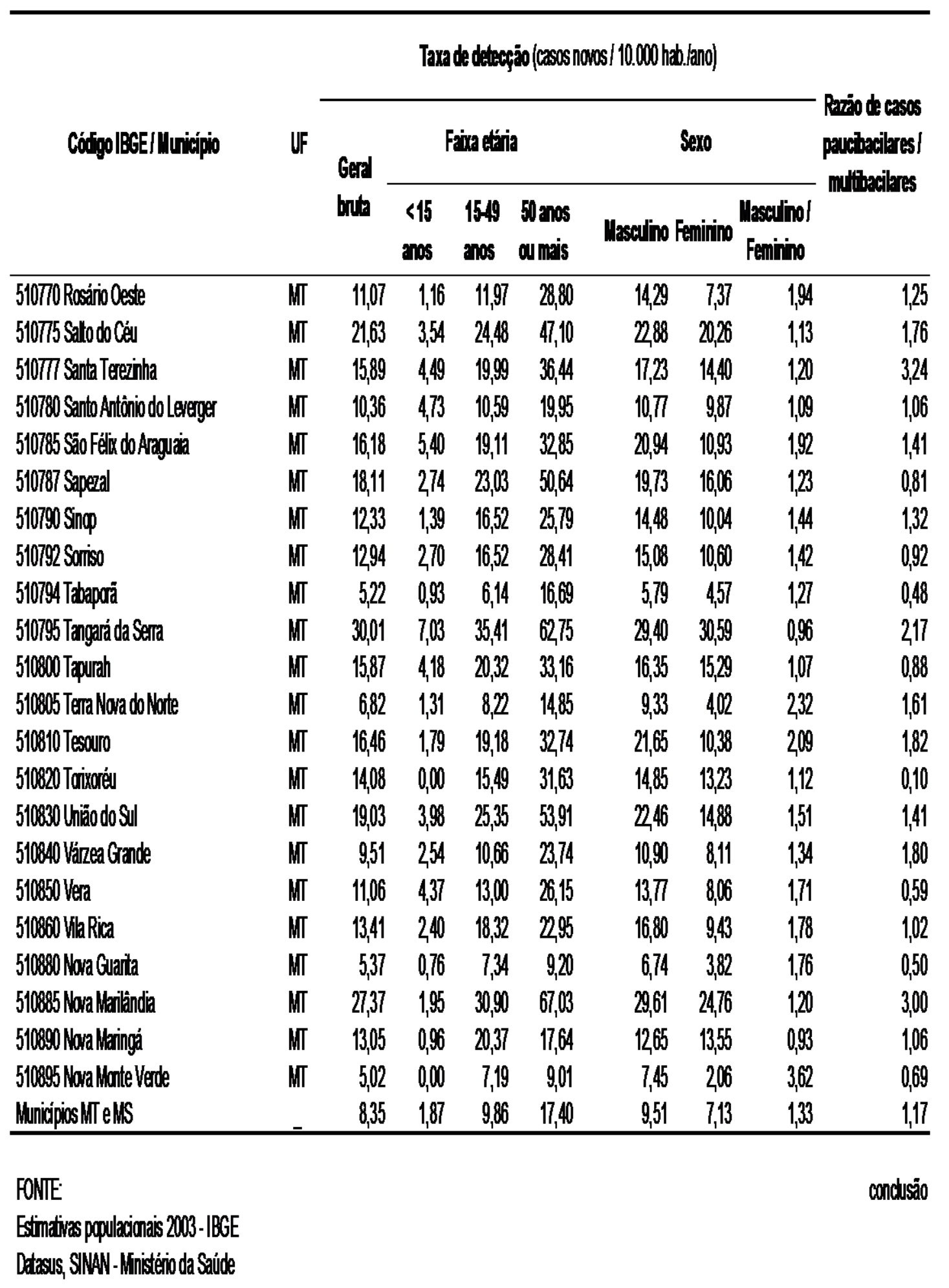


8. Referências 



\section{Referências}

Abreu MAMM, Michalany NS, Weckx LLM, Pimentel DRN, Hirata CIW, Alchorne MMA. A mucosa oral na hanseníase: um estudo clínico e histopatológico. Rev Bras Otorrinolaringol. 2006; 72 (3): 312-6.

Acha PN, Szyfres B. Zoonosis y enfermedades transmisibles comunes al hombre y a los animales. $2^{2}$ ed. Washington: OPAS/OMS; 1989. p.105-12: Lepra (Publicación Científica n. 503).

Albuquerque MFPM, Morais HMM, Ximenes R. A expansão da hanseníase no nordeste brasileiro. Rev Saude Publica. 1989; 23 (2):107-16.

Almeida GS, Vieira Junior PA, RAMOS P. Os Programas de Desenvolvimento Econômico do Centro-Oeste Brasileiro e suas consequências: anos 60 e 70 . Associação Latino-Americana de Sociologia Rural [internet] - ALASRU. [citado 20 dez 2010]. Disponível em: http://www.alasru.org/ cdalasru2006.

Almeida-Filho N. A Saúde e o Paradigma da Complexidade [monografia]. São Leopoldo: Instituto Humanitas Unisinos; 2004. 
Alves E, Lopes M, Contini E. O empobrecimento da agricultura brasileira. Revista de Política Agrícola [periódico online]. 1999; 8 (3): 5-19 [citado 13 abril 2011]. Disponível em: http://www.conab.gov.br/OlalaCMS/uploads/arquivos.

Andrade MC. Geografia, ciência da sociedade. São Paulo: Atlas; 1987.

Andrade VLG, Sabroza PC, Araújo AJG. Fatores Associados ao Domicílio e à Família na Determinação da Hanseníase, Rio de Janeiro, Brasil. Cad Saude Publica. 1994; 10 (Supl 2): 281-92.

Andrade VLG. Evolução da hanseníase no Brasil e perspectivas para sua eliminação como um problema de Saúde Pública. [tese]. Rio e Janeiro: Escola Nacional de Saúde Pública, Fundação Oswaldo Cruz; 1996.

Andrade V. Implementação da PQT/OMS no Brasil. Hansen Int. 2006; 31 (1): 23-31.

Arruda R. Populações Tradicionais e a Proteção dos Recursos Naturais em Unidades de Conservação. Ambiente e Sociedade. 1999; 2 (5): 79-92.

Azevedo RS, Menezes RX. Correlação e Regressão. In: Massad E, Menezes RX, Silveira PSP, Ortega NRS. Métodos Quantitativos em Medicina. Barueri: Manole, 2004. p. 277-93. 
Ayres JRCM. Sobre o risco. Para compreender a epidemiologia. São Paulo: Hucitec; 1997.

Bakker MI, Hatta M, Kwenang A, Mosseveld PV, Faber WR, Klatser PR, Oskam L. Risk factors for developing leprosy - a population-based cohort study in Indonesia. Lepr Rev. 2006; 77: 48-61.

Baldy JLS. Introdução ao Estudo das Doenças Transmissíveis I. In: Amato Neto V, Baldy JLS, editores. Doenças Transmissíveis. São Paulo: Sarvier; 1989. p. $1-11$.

Banerjee R, Bnerjee BD, Chaudhury S, Hati AK. Transmission of viable Mycobacterium leprae by Aedes aegipty from lepromatous leprosy patients to the skin of mice through interrupted feeding. Lepr Rev. 1991; 62: 21-6.

Barata RCB. Epidemias. Cad Saude Publica. 1987; 3 (1): 9-15.

Barata RCB. Epidemiologia Social. Rev Bras Epidemiol. 2005; 9 (1): 7-17.

Barcellos C. Problemas Emergentes da Saúde Coletiva e a Revalorização do Espaço Geográfico. In: Miranda AC, Barcellos C, Moreira JC, Monken M, organizadores. Território, Ambiente e Saúde. Rio de Janeiro: Fiocruz; 2008. p. $43-55$. 
Barreto JA. Avaliação de pacientes com hanseníase na faixa virchowiana diagnosticados entre 1990 e 2000 e tratados com poliquimioterapia 24 doses e seus comunicantes na fase de pós-eliminação em municípios de Santa Catarina [tese]. São Paulo: Universidade de São Paulo; 2011.

Barreto ML, Teixeira MG, Bastos FI, Ximenes RAA, Barata RB, Rodrigues LC. Sucessos e fracassos no controle de doenças infecciosas no Brasil: o contexto social e ambiental, políticas, intervenções e necessidades de pesquisa. Séries, Saúde no Brasil 3; p. 47-60. [citado 9 maio 2011]. Disponível em: www.thelancet.com.

Barro MPAA. Avaliação da situação da hanseníase no município de Londrina de 1997 a 2001: aspectos epidemiológicos, operacionais e organizacionais. Hans Int. 2004; 29 (2): 110-7.

Bechelli LM, Curban G V. Compêndio de Dermatologia. $5^{\text {a }}$ ed. São Paulo: Atheneu; 1978. p. 122-51: Lepra.

Bechelli LM. Hanseníase. In: Veronesi R, Foccacia R, Dietze R, editores. Doenças Infecciosas e Parasitárias. 8 $^{\mathrm{a}}$ ed. Rio de Janeiro: GuanabaraKoogan, 1991. p. 349-66.

Becker BK. Amazônia: Geopolítica na virada do III milênio. $2^{\text {a }}$ ed. Rio de Janeiro: Garamond, 2004. 
Beers SM, Hatta M, Klatser PR. Patient contact is the major determinant in incident leprosy: implications for future control. Int $J$ Lepr Other Mycobact Dis. 1999; 67 (2): 119-28.

Beers SM, Izumi S, Madjid B, Maeda Y, Day R, Klatser PR. An epidemiological study of leprosy infection by serology and polymerase chain reaction. Int J Lepr Other Mycobact Dis. 1994; 62 (1): 1-9.

Beiguelman B. A reação de Mitsuda oitenta anos depois. Hans Int. 1999; 24 (2): 144-61.

Beiguelman B. Genética e hanseníase. Ciênc. saúde colet. 2002; 7 (1): $117-$ 28.

Belda W. Aspectos da hanseníase na área urbana do Município de São Paulo: Hanseníase indiferenciada, 1963-1977. Hans Int. 1981; 6 (1): 23-50.

Bellanti JA. Mecanismos de defesa contra agentes infecciosos. In: Bellanti JA. Imunologia. $2^{\text {a }}$ edição. Rio de Janeiro: Interamericana; 1980.

Benard G. An overview of the immunopathology of human paracoccidioidomycosis. Mycopathologia. 2008; 165:209-21. 
Benchimol JL, Romero Sá M. Adolpho Lutz and controversies over the transmission of leprosy by mosquitoes. Hist Cienc Saude Manguinhos. 2003; 10 (suppl. 1): 49-93.

Bernardes JA. Dimensões da ação e novas territorialidades no cerrado brasileiro: pistas para uma análise teórica. Revista NERA [periódico online]. 2007; 10 (10): 1-10 [citado 13 abril 2011]. Disponível em: http://www4.fct. unesp.br/nera.

Bernier GM. Anticorpos e Imunoglobulinas: estrutura e função. In: Bellanti JA. Imunologia. $2^{2}$ edição. Rio de Janeiro: Interamericana; 1980.

Beyene D, Aseffa A, Harboe M, Kidane D, MacDonald M, Klatser PR, Bjune GA, Smith WCS. Nasal carriage of Mycobacterium leprae DNA in healthy individuals in Lega Robi village, Ethiopia. Epidemiol Infect. 2003; 131: 841-8.

Boggild AK, Correia JD, Keystone JS, Kain KC. Leprosy in Toronto: an analysis of 184 imported cases. CMAJ. 2004; 170 (1): 55-9.

Bonelli R (Empresa Brasileira de Pesquisa Agropecuária - Embrapa). Impactos Econômicos e Sociais de Longo Prazo da Expansão Agropecuária no Brasil: Revolução invisível e inclusão social [on-line]. Rio de Janeiro: Instituto de Pesquisa Econômica Aplicada - IPEA; 2001. Relatório Técnico. Texto para discussão ํํ 838. Disponível em: http://www.embrapa.br. 
Bousquat A, Cohn A. A dimensão espacial nos estudos sobre saúde: uma trajetória histórica. Hist Cienc Saude Manguinhos. 2004; 11 (3): 549-68.

Bracken MB. The first epidemiologic text. Am J Epidemiol. 2003; 157 (9): 855-6.

Bradley DJ. Regulation of parasite populations. Trans Royal Soc Trop Med Hyg. 1972; 66: 697-708.

Brasil. Ministério da Saúde. Secretaria Nacional de Programas Especiais de Saúde. Divisão Nacional de Dermatologia Sanitária. Controle da Hanseníase. Rio de janeiro: Divisão Nacional de Dermatologia Sanitária; Núcleo de Tecnologia Educacional para a Saúde, Universidade Federal do Rio de Janeiro, Fundação Universitária José Bonifácio, 1989.

Brasil. Lei n. 8.080 de 19 de setembro de 1990. Dispõe sobre as condições para a promoção, proteção e recuperação da saúde, a organização e o funcionamento dos serviços correspondentes e dá outras providências. Diário Oficial da União, Brasília (DF). 20 set. 1990a.

Brasil. Lei n. 8.142 de 28 de dezembro de 1990. Dispõe sobre a participação da comunidade na gestão do Sistema Único de Saúde (SUS) e sobre as transferências intergovernamentais de recursos financeiros na área da 
saúde e dá outras providências. Diário Oficial da União, Brasília (DF). 31 dez. 1990b.

Brasil. Ministério da Saúde. Secretaria Nacional de Programas Especiais de Saúde. Divisão Nacional de Dermatologia Sanitária. Relatórios técnicos. Brasília (DF), 1998.

Brasil. Lei n. 9.785 de 29 de janeiro de 1999. Altera o Decreto-Lei no 3.365, de 21 de junho de 1941 (desapropriação por utilidade pública) e as Leis nos 6.015, de 31 de dezembro de 1973 (registros públicos) e 6.766, de 19 de dezembro de 1979 (parcelamento do solo urbano). Diário Oficial da União, Brasília (DF). 1ํ fev. 1999.

Brasil. Ministério da Saúde. Secretaria de Assistência à Saúde. Coordenação de Saúde da Comunidade. Saúde da Família: uma estratégia para a reorientação do modelo assistencial. Brasília (DF), 1997.

Brasil. Ministério da Saúde. Portaria n. 1073/GM de 26 de setembro de 2000. Diário Oficial da União, Brasília (DF). 28 set. 2000.

Brasil. Ministério da Saúde. Secretaria de Políticas de Saúde. Departamento de Atenção Básica. Guia para o Controle da Hanseníase. Brasília (DF): Ministério da Saúde, 2002. 
Brasil. Ministério da Saúde. Secretaria de Vigilância em Saúde. Guia de Vigilância Epidemiológica. 6ª ed. Brasília (DF): Ministério da Saúde, 2005.

Brasil. Ministério da Saúde. Política Nacional de Atenção Básica. Série Pactos pela Saúde. Brasília (DF): Ministério da Saúde, 2006a.

Brasil. Ministério da Saúde. Secretaria de Gestão Estratégica e Participativa. A construção do SUS: histórias da Reforma Sanitária e do Processo Participativo. Brasília (DF): Ministério da Saúde, 2006b. Série I. História da Saúde no Brasil.

Brasil. Ministério da Saúde. Secretaria de Atenção à Saúde. Departamento de Atenção Básica. Vigilância em saúde: dengue, esquistossomose, hanseníase, malária, tracoma e tuberculose. Brasília (DF): Ministério da Saúde, 2007.

Brasil. Ministério da Saúde. Secretaria de Vigilância em Saúde. Departamento de Vigilância Epidemiológica. Vigilância em Saúde: situação epidemiológica da hanseníase no Brasil. [citado 6 dez 2008a]. Disponível em: http://portal.saude.gov.br/portal/arquivos/pdf/boletim_novembro.pdf.

Brasil. Ministério da Saúde. Departamento de Informática do SUS - Datasus. Informações de Saúde Epidemiológicas e de Morbidade: Doenças de 
Notificação. Acompanhamento da hanseníase [citado 6 dez 2008b]. Disponível em: http://www.dtr2004.saude.gov.br/sinanweb.

Brasil. Ministério da Saúde. Departamento de Informática do SUS - Datasus. Informações de Saúde Epidemiológicas e de Morbidade: Doenças de Notificação. Relatório Gerencial sobre completude de campos essenciais, Sinanweb [citado 6 dez 2008c]. Disponível em: http://www.dtr2004.saude. gov.br/sinanweb.

Brasil. Ministério da Saúde. Departamento de Informática do Sistema Único de Saúde. Informações de Saúde: Indicadores do Pacto de Atenção Básica 2006. Brasília (DF): Ministério da Saúde [citado 22 set 2009a]. Disponível em: http://www2.datasus.gov.br/ DATASUS.

Brasil. Conselho Nacional de Secretários de Saúde (CONASS). SUS 20 anos. Brasília (DF): CONASS, 2009b.

Brasil. Ministério da Saúde. Secretaria de Vigilância em Saúde. Departamento de Vigilância Epidemiológica. Doenças Infecciosas e Parasitárias. 8ª edição. Brasília (DF): Ministério da Saúde; 2010. Cap. 32, p. 206-16: Hanseníase.

Brasil. Ministério do Transportes. Mapas e Informações [citado $26 \mathrm{fev}$ 2011a]. Disponível em: http://www.transportes.gov.br. 
Brasil. Ministério do Desenvolvimento, Indústria e Comércio Exterior. Balança Comercial. Unidades da Federação, 2000 [citado 26 fev 2011b]. Disponível em: http://www.mdic.gov.br.

Brasil. Ministério da Saúde. Departamento de Informática do Sistema Único de Saúde. Informações de Saúde. Brasília (DF): Ministério da Saúde [citado 31 jul 2011c]. Disponível em: http://www2.datasus.gov.br/ DATASUS.

Britto RS. Hansenose em foco na Região Norte do Brasil - 1986. Hansen Int. 1989; 14 (2): 87-100.

Brightbill HD, Libraty DH, Krutzik SR, Yang RB, Belisle JT, Bleharski JR,M Maitland M, Norgard MV, Scott EP, Smale ST, Brennan P, Bloom BR, Godowski PJ, Modlin RL. Host defense mechanisms triggered by microbial lipoproteins through toll-like receptors. Science. 1999; 285: 732-6.

Browne SG. The history of leprosy. In: Hastings RC, editor. Leprosy. London: Churchill Livingstone, 1985. p.1-13.

Bryceson A. The relative importance of specific immunity in protecting against leprosy. Lepr Rev. 1981; 52 (Suppl 1): 93-107. 
Bryceson ADM. Leprosy. In: Champion RH, Burton JL, Ebling FLG, editors. Textbook of dermatology. 5th ed. Oxford: Blackwell Scientific Publications, 1992. p.1065-83.

Bullock WE. Leprosy: a model of immunological perturbation in chronic infection. J Infect Dis. 1978; 137: 341-54.

Bullock WE. Leprosy. In: Mandell GL, Douglas Jr RG, Bennett JE, editors. Principles and Practice of Infectious Diseases. 2nd ed. New York: Churchill Livingstone, 1979. p. 1406-13.

Calado KLS, Vieira AG, Durães S, Sékula SB, Oliveira MLW. Positividade sorológica antiPGL-I em contatos domiciliares e peridomiciliares de hanseníase em área urbana. An Bras Dermatol. 2005; 80 (Supl 3): 301-6.

Camargo EP. Doenças Tropicais. Estudos Avançados. 2008; 22 (64): 95110.

Camarinha Marcos EV. Imunogenética. In: Opromolla DVA, editor. Noções de Hansenologia. Bauru: Centro de Estudos Dr. Reynaldo Quagliato, 2000. p. 43-6.

Cândido A. Os parceiros do Rio Bonito. 9aㅗ ed. São Paulo: Duas cidades; Editora 34, 2001. p. 21-41: O problema dos meios de vida. 
Cardona-Castro N, Beltrán JC, Ortiz-Bernal A, Vissa V. Detection of Mycobacterium leprae DNA in nine-banded armadillos (Dasypus novemcinctus) from the Andean region of Colombia. Lepr Rev. 2009; 80: 424-31.

Carvalheiro JR. Processo migratório e disseminação de doenças. In: Textos de Apoio em Ciências Sociais. $2^{\mathrm{a}}$ ed. Rio de Janeiro: Abrasco, 1986. p. 2955.

Chame M. Dois séculos de crítica ambiental no Brasil e pouco mudou. In: Minayo MCS, Miranda AC, organizadores. Saúde e Ambiente Sustentável: estreitando nós. Rio de Janeiro: Fiocruz; Abrasco, 2006. p. 55-60.

Chaturvedi RM. Epidemiological study of leprosy in Malwani suburb of Bombay. Lepr Rev. 1988; 59: 113-20.

Chehl S, Job CK, Hastings RC. Transmission of leprosy in nude mice. Am J Trop Med Hyg. 1985; 34: 1161-6.

Cidade LCF. Visões de mundo, visões da natureza e a formação de paradigmas geográficos. Terra Livre. 2001; 17: 99-118. 
Cooper DB. The New Black Death: Cholera in Brazil, 1855-1856. In: Kenneth K (editor). The African Exchange. Toward a Biological History of Black People. Durham: Duke University Press, 1987. p.235-56.

Costa MCL. Teorias médicas e gestão urbana: a seca de 1877-79 em Fortaleza. Hist Cienc Saude Manguinhos. 2004; 11(1): 57-74.

Costa MCN, Teixeira MGLC. A concepção de "espaço" na investigação epidemiológica. Cad Saude Publica. 1999; 15 (2): 271-79.

Costa MVV. Expansão do Agronegócio e Logística de Transporte no Estado de Mato Grosso. In: 15 Encontro Nacional de Geógrafos; 2008; São Paulo [on-line]. Rio de Janeiro: Associação dos Geógrafos do Brasil. Disponível em: http://www.nuclamb.geografia.ufrj.br.

Coutinho AC. Condicionantes da expansão da fronteira agrícola em Mato Grosso. Revista de Política Agrícola [periódico online]. 2009; 18 (1): 80-97 [citado 13 abril 2011]. Disponível em: http://www.conab.gov.br/ OlalaCMS/ uploads/arquivos.

Coutinho FAB. A Matemática das Epidemias. In: Massad E, Menezes RX, Silveira PSP, Ortega NRS. Métodos Quantitativos em Medicina. Barueri: Manole, 2004. p. 55-74. 
Cree IA, Smith WC. Leprosy transmission and mucosal immunity: towards eradication? Lepr Rev. 1998; 69: 112-21.

Cunha JMP, Almeida GMR, Raquel F. Migração e Transformações Produtivas na Fronteira: o caso de Mato Grosso. In: 13ํㅡㄹ Encontro da Associação Brasileira de Estudos Populacionais - ABEP [internet]; 2002; Ouro Preto [citado 13 abril 2011]. Disponível em: http://www.nepo.unicamp.br.

Cunha MD, Cavaliere FAM, Hércules FM, Duraes SMB, Oliveira MLW, Matos HJ. Os indicadores da hanseníase e as estratégias de eliminação da doença, em município endêmico do Estado do Rio de Janeiro, Brasil. Cad Saude Publica. 2007; 23 (5): 1187-97.

Cunha SS, Rodrigues LC, Moreira S, Carvalho LC, Barreto ML, Dourado I. Upward trend in the rate of detection of new cases of leprosy in the State of Bahia, Brazil. Int J Lepr Other Mycobact Dis. 2001; 69 (4): 308-17.

Czeresnia D, Ribeiro AM. O conceito de espaço em epidemiologia: uma interpretação histórica e epistemológica. Cad Saude Publica. 2000; 16 (3): 595-617.

Davey TF, Rees RJW. The nasal discharge in leprosy: clinical and bacteriological aspects. Lepr Rev. 1974; 45: 121-34. 
Deps PD. Como o Mycobacterium leprae é transmitido? Hans Int. 2001; 26 (1): 31-36.

Desikan KV, Sreevatsa. Extended studies on the viability of Mycobacterium leprae outside the human body. Lepr Rev. 1995; 66: 287-95.

Dharmendra. Classifications of leprosy. In: Hastings RC, editor. Leprosy. London: Churchill Livingstone, 1985, p. 88-99.

Dias MCFS, Nobre ML, Dias GH. Distribuição espacial da hanseníase no município de Mossoró/RN, utilizando o Sistema de Informação Geográfica SIG. An Bras Dermatol. 2005; 80 (Supl 3): 289-94.

Diez-Roux AV. Bringing context back into epidemiology: variables and fallacies in multilevel analysis. Am J Public Health. 1998; 88: 216-22.

Diez-Roux AV. A glossary for multilevel analysis. J Epidemiol Community Health. 2002; 56: 588-94.

Duerksen F. Reabilitação. In: Opromolla DVA, editor. Noções de Hansenologia. Bauru: Centro de Estudos Dr. Reynaldo Quagliato, 2000. p. 113-115. 
Dufault B, Klar N. The Quality of Modern Cross-Sectional Ecologic Studies: A Bibliometric Review. Am J Epidemiol. 2011; 174 (10): 1101-7.

Edmunds WJ, Kafatos G, Wallinga J, Mossong JR. Mixing patterns and the spread of close-contact infectious diseases. Emerging Themes in Epidemiology. 2006; 3:10. [cited 2011 aug 13]. Available from: http://www.ete-online.com/content/3/1/10.

Eidt LM. Breve história da hanseníase: sua expansão do mundo para as Américas, o Brasil e o Rio Grande do Sul e sua trajetória na saúde pública brasileira. Saúde e Sociedade. 2004; 13 (2): 76-88.

Elliott P, Wakefield JC. Bias and confounding in spatial epidemiology. In: Elliott P, Wakefield JC, Best NG, Briggs DJ. Spatial Epidemiology. Oxford: Oxford University Press; 2001. p. 68-84.

Esquenazi DA. Mecanismos de Reversão de Hiporresponsividade Imunológica em Doenças Infecciosas Crônicas [tese]. Rio de Janeiro: Faculdade de Ciências Médicas da Universidade do Estado do Rio de Janeiro; 2007.

Façanha MC, Pinheiro AC, Lima JRC, Ferreira MLLT, Teixeira GFD, Rouquayrol, MZ. Hanseniase: subnotificacao de casos em Fortaleza - Ceará, Brasil. An Bras Dermatol. 2006; 81 (4): 329-33. 
Farenzena D, Tonini IM, Cassol R. Considerações sobre a temática ambiental em Geografia. Geografia: Ensino \& Pesquisa. 2001, 11 (1): 1-8.

Feitosa MF, Borecki I, Krieger H, Beiguelman B, Rao DC. The genetic epidemiology of leprosy in a brazilian population. Am J Hum Genet. 1995; 56: 1179-85.

Feldman RA, Sturdivant M. Leprosy in Louisiana, 1855-1970. Am J Epidemiol. 1975; 102 (4): 303-10.

Fernández AJC. Do Cerrado à Amazônia: as estruturas sociais da economia da soja em Mato Grosso [tese]. Porto Alegre: Universidade Federal do Rio Grande do Sul; 2007.

Ferreira IN, Alvarez RRA. Hanseníase em menores de quinze anos no município de Paracatu, MG (1994 a 2001). Rev bras Epidemiol. 2005; 8 (1): 41-9.

Ferreira J. Vigilância Epidemiológica em Hanseníase. In: Lombardi C, Ferreira J, Motta, CP, Oliveira MLW, editores. Hanseníase. São Paulo: Imprensa Oficial do Estado, Arquivo do Estado; 1990. p. 33-61.

Ferreira MU. Epidemiologia e Geografia: o complexo patogênico de Max Sorre. Cad Saude Publica. 1991; 7: 301-9. 
Ferreira SMB, Esperandio E, Ignotti E, Gamba MA. Magnitude da hanseníase no estado do Mato Grosso: situação epidemiológica. [on-line] Hans Int. 2007 [citado 23 mar 2011]; 32 (Supl) - Anais do 3 Simpósio Brasileiro de Hansenologia; 2007. Anais. Disponível em: htpp://www.ilsl.gov.br.

Figueiredo IA, Silva AAM. Aumento na detecção de casos de hanseníase em São Luís, Maranhão, Brasil, de 1993 a 1998. A endemia está em expansão? Cad Saude Publica. 2003; 19 (2): 439-45.

Fine PEM. Problems in collection and analysis of data in leprosy studies. Lepr Rev. 1981; 52 (Suppl 1): 197-206.

Fine PEM. Leprosy: the epidemiology of a slow bacterium. Epidemiol Rev. 1982; 4: 161-88.

Flach DMAM, Andrade M, Valle CLP, Pimentel MIF, Mello KT. Análise da série histórica do período de 2001 a 2009 dos casos de hanseníase em menores de 15 anos, no estado do RJ. Hansen Int. 2010; 35 (1): 13-20.

Fleury RN. Propriedade da pesquisa em hanseníase no Brasil [editorial]. Hans Int. 2005; 30 (1): 1. 
Foss NT, Callera F, Alberto FL. Anti-PGL1 levels in leprosy patients and their contacts. Braz J Med Biol Res. 1993; 26 (1): 43-51.

Frost WH. Epidemiology. In: Maxcy KF. Papers of Wade Hampton Frost: a contribution to epidemiological method. New York: Commonwealth Fund; 1941.

Gallo MEN, Sampaio E, Nery JAC, Moraes MO, Antunes SL, Pessolani MCV, Sarno EN. Cap. 116. Hanseníase: Aspectos Epidemiológicos, Clínicos e Imunológicos. In: Coura JR, editor. Dinâmica das Doenças Infecciosas e Parasitárias. Rio de Janeiro: Guanabara Koogan, 2005. p. 1383-94.

Ganapati R, Revankar CR, Bulchand HO, Kingsley S. The Dharavi story Saga of LECs over 2 decades. Lepr Rev. 1999; 70: 495-7.

Garbino JA. In: Opromolla DVA, editor. Noções de Hansenologia. Neuropatia hanseniana. Bauru: Centro de Estudos Dr. Reynaldo Quagliato, 2000. p. 7989.

Geater JG. The fly as potential vector in the transmission of leprosy. Lepr Rev. 1975; 46: 279-86.

Geluk A, Ottenhoff TH. HLA and leprosy in the pre and postgenomic eras. Hum Immunol. 2006; 67 (6): 439-45. 
Genevois MLBP, Costa OV. Carência Habitacional e Déficit de Moradias. São Paulo em Perspectiva. 2001; 15 (1): 73-84.

Gentilini M, Duflo B, Danis M, Lagardère B, Richard-Lenoble D, Brucker G, Mouchet J, Rosenheim M. Medicine Tropicale. Paris: Médicine-Sciences Flammarion; 1986. p. 273-90: Lèpre.

Godal T, Negassi K. Subclinical Infection in Leprosy. BMJ. 1973; 3: 557-9.

Godal T. Leprosy immunology: some aspects of the role of the immune system in the pathogenesis of disease. Lepr Rev. 1984; 55 (4): 407-14.

Godelier M. O enigma do dom. Rio de Janeiro: Civilização Brasileira, 2001.

Goldbaum M. Doença de Chagas e Trabalho em Área Urbana [dissertação]. São Paulo: Universidade de São Paulo; 1976.

Gonçalves CWP. Processos planetários e fronteiras móveis: reflexões a partir da obra de Milton Santos. In: Brandão MA, organizadora. Milton Santos e o Brasil. São Paulo: Fundação Perseu Abramo; 2004. 
Goulart IMB, Penna GO, Cunha G. Imunopatologia da hanseníase: a complexidade dos mecanismos da resposta imune do hospedeiro ao Mycobacterium leprae. Rev Soc Bras Med Trop. 2002; 35 (4): 365-75.

Goulart IMB, Santos MS, Muniz DLO, Barbosa FM, Netto Cardoso J, Chaves JGM, Guedes JT, Queiroz LB, Nascimento VA, Silva YA. Caracterização da endemia hansênica no município de Uberlândia - Minas Gerais, Brasil 19962000. Hans Int. 2006; 31 (1): 33-40.

Gouveia N. Saúde e Meio Ambiente nas Cidades: Os Desafios da Saúde Ambiental. Saúde e Sociedade. 1999; 8 (1): 49-61.

Gouveia N. Espaço, Ambiente e Saúde: Um olhar epidemiológico [tese]. São Paulo: Faculdade de Medicina da Universidade de São Paulo; 2009.

Greenland S, Morgenstern H. Ecological Bias, Confounding, and Effect Modification. Int J Epidemiol. 1989; 18: 269-4.

Greenland S. Introduction to Regression Models. In: Rothman JK, Greenland S, editors. Modern Epidemiology. 3th ed. Philadelphia: Lippincott-Raven publishers, 2008. p. 381-417.

Hair JF, Tatham RL, Anderson RE, Black W. Análise Multivariada de Dados. $5^{\mathrm{a}}$ ed. Porto Alegre: Bookman, 2005 
Halloran ME. Concepts of Transmission and Dynamics. In: Thomas JC, Weber D, editors. Epidemiologic Methods for the Study of Infectious Disease. Oxford University Press, 2001. p. 56-85.

Harboe M. The immunology of Leprosy. In: Hastings RC, editor. Leprosy. London: Churchill Livingstone, 1985. p. 53-87.

Hatta H, van Beers SM, Madjib B, de Wit MYL, Klatser PR. Distribution and persistence of Mycobacterium leprae nasal carriage among a population in which leprosy is endemic in Indonesia. Trans Royal Soc Trop Med Hyg. 1995; (89): 381-5.

Hegazy AA, Abdel-Hamid IA, Ahmed El-Shahat F, Hammad SM, Hawas SA. Leprosy in a high-prevalence Egyptian village: epidemiology and risk factors Int J Dermatol. 2002; 41: 681-6.

Helene LMF, Salum MJL. A reprodução social da hanseníase: um estudo do perfil de doentes com hanseníase no Município de São Paulo. Cad Saude Publica. 2002; 18 (1): 101-13.

Herscowitz HB. Imunofisiologia: as interações e funções celulares. In: Bellanti JA. Imunologia. 2ª edição. Rio de Janeiro: Interamericana; 1980. 
Hertz-Picciotto I. Environmental Epidemiology. In: Rothman JK, Greenland S. Modern Epidemiology. 2nd ed. Philadelphia: Lippincott-Raven Publishers; 2008. p. 598-619.

Hosmer DW, Lemeshow S. Applied Logistic Regression. 2nd. ed. New York: John Wiley \& Sons, 2002.

Huan-Ying L, Yu-Lin P, Yang W. Leprosy Control in Shandong Province, China, 1955-1983; some Epidemiological Features. Int J Lepr Other Mycobact Dis. 1985; 53 (1): 79-85.

Huang C. The transmission of leprosy in man. Int $J$ Lepr Other Mycobact Dis. 1980; 48 (3): 309-21.

Hunter JM, Thomas MO. Hypothesis of leprosy, tuberculosis and urbanization in Africa. Soc Sci Med. 1984; 19 (1): 27-57.

IBGE. Instituto Brasileiro de Geografia e Estatística. População. Estimativas de população. IBGE [citado 5 dez 2007] Disponível em: http://www.ibge.gov.br. 
IBGE. Instituto Brasileiro de Geografia e Estatística. População. Censos demográficos. Censo Demográfico 2000. IBGE [citado 20 jan 2008]. Disponível em: http://www.ibge.gov.br.

IBGE. Instituto Brasileiro de Geografia e Estatística. Metodologia do Censo Demográfico 2000. Censo Demográfico 2000. Rio de Janeiro: IBGE; 2003.

IBGE. Instituto Brasileiro de Geografia e Estatística. Economia. Sistema de Contas Nacionais. IBGE [citado 16 dez 2009]. Disponível em: http://www.ibge.gov.br.

IBGE. Instituto Brasileiro de Geografia e Estatística. População. Síntese de Indicadores Sociais. Uma Análise das Condições de Vida da População Brasileira. IBGE [citado 28 out 2010a]. Disponível em: http://www.ibge.gov.br.

IBGE. Instituto Brasileiro de Geografia e Estatística. População. Pesquisa Nacional por Amostra de Domicílios - PNAD 2008. IBGE [citado 28 out 2010b]. Disponível em: http://www.ibge.gov.br.

IBGE. Instituto Brasileiro de Geografia e Estatística. População. Censos demográficos. Censo demográfico 2010. IBGE [citado 16 mar 2011]. Primeiros Resultados. Disponível em: http://www.ibge.gov.br. 
Ignotti E, Rodrigues AM, Andrade VLG, Valente, JG. Aplicação de métodos de estimativa da prevalência de hanseníase no Estado de Mato Grosso. Rev bras epidemiol. 2004; 7 (2): 155-66.

Imbiriba ENB, Silva Neto AL, Souza WV, Pedrosa V, Cunha MG, Garnelo L. Desigualdade social, crescimento urbano e hanseníase em Manaus: abordagem espacial. Rev Saude Publica. 2009; 43 (4): 656-65.

Instituto de Pesquisa Social Aplicada (IPEA). Políticas Sociais: acompanhamento e análise. Brasília: Ipea; 2008.

Irgens LM, Bjerkedal T. Epidemiology of Leprosy in Norway: the History of The National Leprosy Registry of Norway from 1856 until today. Int $J$ Epidemiol. 1973; 2 (1): 81-89.

Irgens LM. Leprosy in Norway. Oxford: Lepra Association, 1980.

Irgens LM. Epidemiological aspects and implications of the disappearance of leprosy from Norway; some factors contributing to the decline. Lepr Rev. 1981; 52 (Suppl 1): 147-65. 
Irgens LM. Secular trends in leprosy: increase in age at onset associated with declining rates and long incubation periods [editorial]. Int $J$ Lepr Other Mycobact Dis. 1985; 53 (4): 610-615.

Irgens LM, Skajaerven R. Secular trends in age at onset, sex ratio, and type index in leprosy observed during declining incidence rates. Am J Epidemiol. 1985; 122 (4): 695-705.

Izumi S, Budiawan T, Saeki K, Matsuoka M, Kawatsu K. An epidemiological study on Mycobacterium leprae infection and prevalence of leprosy in endemic villages by molecular biological technique. Indian J Lepr. 1999; 71 (1): $37-43$.

Jesudasan K, Vijayakumaran P, Manimozhi N, Bushanam JDRS, Kanagarajan S, Sundar Rao, PSS. Origin of new leprosy cases during general surveys in relation to previous survey findings. Lepr Rev. 1996; 67 (3): 183-9.

Job CK. Leprosy - the source of infection and its mode of transmission. Lepr Rev. 1981; 52 (1): 69-76.

Jopling WH, McDougall AC. Manual de Hanseníase. $4^{\underline{a}}$ ed. Rio de Janeiro: Atheneu, 1991. 
Joseph BZ, Yoder LJ, Jacobson RR. Hansens disease in native-born citizens of the United States. Public Health Rep. 1985; 100: 666-71.

Kaufman JS. Social Epidemiology. In: Rothman JK, Greenland S, Lash TL, editors. Modern Epidemiology. 3th ed. Philadelphia: Lippincott Willians \& Wilkins, 2008. p. 532-48.

Kazda J. Occurrence of non-cultivable acid-fast bacilli in the environment and their relationship to M. leprae. Lepr Rev. 1981; 52 (1): 85-91.

Kazda J, Ganapati R, Revankar C, Buchanan TM, Young DB, Irgens LM. Isolation of environment-derived Mycobacterium leprae from soil in Bombay. Lepr Rev. 1986; 57 (Suppl 3): 201-8.

Kazda J, Irgens LM. Acid-fast bacilli found in sphagnum vegetation of coastal Norway containing Mycobacterium leprae specific phenolic glycolipid-I. Int $J$ Lepr Other Mycobact Dis. 1990; 58 (2): 353-7.

Kerr-Pontes LRS, Montenegro ACD, Barreto ML, Werneck GL, Feldmeier H. Inequality and leprosy in Northeast Brazil: an ecological study. Int $J$ Epidemiol. 2004; 33: 262-9.

Kirkwood BR. Essentials Medical Statistics. Oxford: Blackwell Scientific Publications, 1988. 
Klatser PR, van Beers S, Madjid B, Day R, de Wit MY. Detection of Mycobacterium leprae nasal carriers in populations for which leprosy is endemic. J Clin Microbiol. 1993; 31 (11): 2947-51.

Koopman JS, Longini IR. The Ecological Effects of Individual Exposures and Nonlinear Disease Dynamics in Populations. Am J Public Health. 1994; 84 (5): 836-42.

Krieger N. Epidemiology and Social Sciences: towards a critical reengagement in the 21st century. Epidemiol Rev. 2000; 22 (1): 155-63.

Kumar A, Girdhar A, Yadav VS, Girdhar BK. Some epidemiological observations on leprosy in India. Int J Lepr Other Mycobact Dis. 2001; 69 (3): 234-40.

Laguardia J, Domingues CMA, Carvalho C, Lauerman CR, Macário E, Glatt R. Sistema de Informação de Agravos de Notificação (Sinan): desafios no desenvolvimento de um sistema de informação em saúde. Epidemiologia e Serviços de Saúde. 2004; 13 (3): 135-47.

Lana FCF, Amaral EP, Lanza FM, Lima PL, Carvalho ACN, Diniz LG. Hanseníase em menores de 15 anos no Vale do Jequitinhonha, Minas Gerais, Brasil. Rev Bras Enferm. 2007; 60 (6): 696-700. 
Lana FCF, Lanza FM, Velásquez-Melendez G, Branco AC, Teixeira S, Malaquias LCC. Distribuição da hanseníase segundo sexo no Município de Governador Valadares, Minas Gerais, Brasil. Hans Int. 2003; 28 (2): 131-7.

Lana FCF, Lima RF, Araújo MG, Fonseca PTS. Situação epidemiológica da hanseníase no município de Belo Horizonte/MG - Período 92/97. Hans Int. 2000; 25 (2): 121-32.

Lana FCF, Meléndez JGV, Branco AC, Teixeira S, Malaquias LCC, Oliveira VAC, Rosados V, Lanza FM. Transmissão e Controle da Hanseníase no Município de Governador Valadares/MG - Período de 1990 a 2000. Hans int. 2002; 27 (2): 83-92.

Langen CD. Superinfection with leprosy. International Journal of Leprosy. 1933; 1 (2): 220-5.

Laurenti R, Mello Jorge MHP, Lebrão ML, Gotlieb SLD. Estatísticas de Saúde. São Paulo: Editora Pedagógica e Universitária; 1985. p. 135-46: Padronização de Coeficientes.

Lechat MF. Rationale for the preventive treatment of leprosy. Int J Lepr Other Mycobact Dis. 1999; 67 (Suppl 4): 63-6. 
Leiker DL. On the mode of transmission of Mycobacterium leprae. Lepr Rev. 1977; 48: 9-16.

Leiker DL. A hanseníase. Genebra: Organização Mundial da Saúde, 1977.

Lemos JC, Lima SC. A geografia médica e as doenças infecto-parasitárias. Caminhos de Geografia. 2002; 3 (6): 74-86.

Levy L. Leprosy. In: Hoeprich PD, editor. Infectious Diseases. 3th ed. Philadelphia: Harper and Row Publishers, 1983. p. 945-53.

Lie HP. Why is leprosy decreasing in Norway? International Journal of Leprosy. 1933; 1 (2): 205-16.

Lilienfeld DE. The first epidemiology textbook, revisited. Am J Epidemiol. 2003; 157: 856-7.

Lima CRA. Gestão da qualidade dos dados e informações dos Sistemas de Informação em Saúde: subsídios para a construção de uma metodologia adequada ao Brasil [tese]. Rio de Janeiro: Escola Nacional de Saúde Pública Sérgio Arouca; 2010. 
Litvoc J, Goldbaum M, Silva GR. Determinantes do processo de infestação domiciliar por Panstrongylus megistus: o papel da habitação e do dematamento. Rev Inst Med trop S Paulo. 1990; 32 (6): 443-9.

Lockwood DNJ, Suneetha S. Leprosy: too complex a disease for a simple elimination paradigm. Bull World Health Organ. 2005; 83 (3): 230-5.

Lombardi C. Pesquisa Epidemiológica em Hanseníase In: Lombardi C, Ferreira J, Motta CP, Oliveira MLW, editores. Hanseníase. São Paulo: Imprensa Oficial do Estado; Arquivo do Estado, 1990. p. 63-70.

Lombardi C, Ferreira J. História Natural da Hanseníase. In: Lombardi C, Ferreira J, Motta CP, Oliveira MLW, editores. Hanseníase. São Paulo: Imprensa Oficial do Estado; Arquivo do Estado, 1990. p. 13-20.

Longo JDM, Cunha RV. Perfil clínico-epidemiológico dos casos de hanseníase atendidos no Hospital Universitário em Campo Grande, Mato Grosso do Sul, de janeiro de 1994 a julho de 2005. Hansen Int. 2006; 31 (1): 9-14.

Luna EJA. A emergência das doenças emergentes e as doenças infecciosas emergentes e reemergentes no Brasil. Rev bras epidemiol. 2002; 5 (3): 22943. 
MacMahon B, Pugh TF. Epidemiologic methods. Boston: Little Brown; 1960.

McDougall AC, Rees RJW. Ulcerating lepromatous leprosy in a patient with dapsone-resistant Mycobacterium leprae. Lepr Rev. 1973; 44: 59-64.

Madkan V, Sra K, Tyring SK. The Role of Mucosal Immunity in Protection against Viral Diseases. In: Tyring SK, editor. Mucosal Immunology and Virology. London: Springer; 2006. p. 1-5.

Madrid Congress Number. Int J Lepr Other Mycobact Dis. 1953; 21: 504-10.

Magalhães MCC, Rojas LI. Diferenciação territorial da hanseníase no Brasil. Epidemiologia e Serviços de Saúde. 2007; 16 (2): 75-84.

Magalhães MCC, Santos ES, Queiroz ML, Lima ML, Borges RCM, Souza MS, Ramos AN. Migração e hanseníase em Mato Grosso. Rev Bras Epidemiol. 2011; 14(3): 386-97.

Margarido-Marchese L, Tedesco-Marchese AJ, Rivitti EA. Hanseníase. In: Veronesi R, Focaccia R, editores. Tratado de Infectologia. São Paulo: Atheneu; 1996. p. 714-38.

Marques EC. Os modelos espaciais como instrumento para o estudo de fenômenos urbanos. In: Najar AL, Marques EC, organizadores. Saúde e 
Espaço: Estudos Metodológicos e Técnicas de Análise. $20^{\mathrm{a}}$ ed. Rio de Janeiro: Fiocruz; 1998.

Martelli CMT, Stefani MMA, Penna GO, Andrade ALSS. Endemias e epidemias brasileiras, desafios e perspectivas de investigação científica: hanseníase. Rev bras epidemiol. 2002; 5 (3): 273-85.

Martins JS. Fronteira: a degradação do outro nos confins do mundo. São Paulo: Hucitec, 1997.

Marzliak MLC, Silva RCP, Nogueira W, Guisard CL, Ferreira ME, Metello HN, Lafratta TE, Mohallem DF, Clemente TMG, Macedo HR. Breve histórico sobre os rumos do controle da Hanseníase no Brasil e no Estado de São Paulo. Hansen Int. 2008; 33 (2, Suppl. 1): 39-44.

Mastrangelo G, Scoizzato L, Fadda E, Silva GV, Santos LJ, Cegolon L. Epidemiological pattern of leprosy in an endemic area of North-East Brazil, 1996-2005: the supporting role of a Nongovernmental Organization. Rev Soc Bras Med Trop. 2009; 42(6): 629-32.

Mastro TD, Redd SC, Breiman RF. Imported Leprosy in the United States, 1978 through 1988: An Epidemic without Secondary Transmission. Am J Public Health. 1992; 82 (8): 1127-30. 
Matsumoto M. Mechanism of perpetuation of animal viruses in nature. Bacteriol. Rev. 1969; 33 (3): 404-18.

Matsuoka M, Izumi S, Budiawan T, Nakata N, Saeki K. Mycobacterium leprae DNA in daily using water as a possible source of leprosy infection. Indian J Lepr. 1999; 71 (1): 61-67.

Matsuoka M, Maeda S, Kai M, Nakata N, Chae GT, Gillis TP, Kobayashi K, Izumi S, Kashiwabara Y. Mycobacterium leprae typing by genomic diversity and global distribution of genotypes. Int J Lepr. 2000; 68 (2):121-8.

Matsuoka M, Zhang L, Budiawan T, Saeki K, Izumi S. Genotyping of Mycobacterium leprae on the Basis of the Polymorphism of TTC Repeats for Analysis of Leprosy Transmission. J Clin Microbiol. 2004; 42 (2): 741-45.

Maurano F. História da Lepra em São Paulo. São Paulo: Arquivos do Sanatório Padre Bento; Revista dos Tribunais, 1939.

Megale JF. A Geografia torna-se uma ciência social. In: Sorre M. Geografia. São Paulo: Ática, 1984.

Meima A, Richardus JH, Habbema JDF. Trends in leprosy case detection worldwide since 1985. Lepr Rev. 2004; 75: 19-33. 
Mendonça VA, Costa RD, Melo GEBA, CM Antunes, Teixeira AL. Imunologia da hanseníase. An Bras Dermatol. 2008; 83 (4): 343-50.

Merlin M, Carme B, Laigret J. Impact de la modification profonde des structures d'une société sur l'evolution d'une maladie endemique: la lèpre en Polynésie Française. Bull Soc Pathol Exot. 1976; 69 (5): 442-33.

Meyers WM. Leprosy. In: Strickland TG, editor. Hunter's Tropical Medicine. 6th ed. Philadelphia: W. B. Saunders Company, 1984. p. 409-22.

Meyers WM. Mycobacterial Infections of the Skin. In: Doerr W, Seifert G, editors. Tropical Pathology. Berlin: Springer, 1995. p. 291-319.

Meyers WM. Leprosy. Feigin DR, Cherry JD, editors. Textbook of Pediatric Infectious Diseases. 4th ed. Philadelphia: WB Saunders, 1998. p. 1248-66.

Moet FJ, Meima A, Oskam L, Rlchardus JH. Risk factors for the development of clinical leprosy among contacts, and their relevance for targeted interventions. Lepr Rev. 2004; 75: 310-26.

Monteiro YN. Hanseníase: História e poder no Estado de São Paulo. Hans Int. 1987; $12(1): 1-7$. 
Morabia A. A history of epidemiologic methods and concepts. Basel: Birkhauser Verlag; 2004.

Moraes ACR. Geografia. Pequena História Crítica. São Paulo: Hucitec; 1991.

Moreira MV, Waldman EA, Martins CL. Hanseníase no Estado do Espírito Santo, Brasil: uma endemia em ascensão? Cad Saude Publica. 2008; 24 (7): 1619-30.

Morgenstern H. Ecologic Studies. In: Rothman JK, Greenland S, Lash TL, editors. Modern Epidemiology. 3th ed. Philadelphia: Lippincott Willians \& Wilkins, 2008. p. 511-31.

Motta CP, Zuniga M. Time trends of Hansen's disease in Brazil. Int $J$ Lepr Other Mycobact Dis. 1990; 58 (3): 453-61.

Naafs B. Current views on reaction in leprosy. Indian J Lepr. 2000; 72: 97122.

Naafs B. Factors Influencing the Development of Leprosy: An Overview. Int $J$ Lepr Other Mycobact Dis. 2001; 69 (1): 26-33. 
Nascimento HB. A Lepra em Mato Grosso: caminhos da segregação social e do isolamento hospitalar (1924 - 1941) [dissertação]. Cuiabá: Universidade Federal de Mato Grosso; 2001.

Navarro MBMA, Filgueiras ALL, Coelho H, Ansensi MD, Lemos E, Sidoni M, Soares MS, Cardoso TAO. Doenças Emergentes e Reemergentes, Saúde e Ambiente. In: Minayo MCS, Miranda AC, organizadores. Saúde e Ambiente Sustentável: estreitando nós. Rio de Janeiro: Fiocruz, 2006. p. 367-49.

Neill MA, Hightower AW, Broome CV. Leprosy in the United States, 19711981. J Infect Dis. 1985; 152: 1064-9.

Nemes MIB. A Hanseníase e as Práticas Sanitárias em São Paulo: 10 Anos de Sub-Programa de Controle da Hanseníase na Secretaria de Estado da Saúde (1977-1987) [dissertação]. São Paulo: Faculdade de Medicina, Universidade de São Paulo; 1989.

Nogueira W, Marzliak MLC. Perspectivas da Eliminação da Hanseníase no Estado de São Paulo e no Brasil. Medicina, Ribeirão Preto. 1997; 30 (3): 364-70.

Noordeen SK, Neelan PN. Extended studies on chemoprophylaxis against leprosy. Indian J Med Res. 1978; 67: 515-27. 
Noordeen SK. The Epidemiology of Leprosy. In: Hastings RC, editor. Leprosy. 2nd ed. London: Churchill Livingstone, 1994. p. 29-45.

Noordeen SK. Elimination of leprosy as a public health problem: progress and prospects. Bulletin of the World Health Organization. 1995, 73 (1): 1-6.

Nossa PN. Linhas de investigação contemporâneas na geografia da saúde e a noção holística de saúde. In: Barcellos $C$, organizador. A geografia e o contexto dos problemas de saúde. Rio de Janeiro: Abrasco, 2008. p. 35-62.

Oliveira JED, Abreu MJP, Cortez M, Costa MO, Tararan S. Desenvolvimento sustentável no noroeste de Mato Grosso. Brasília: WWF-Brasil, 2012.

Oliveira MHP, Romanelli G. Os efeitos da hanseníase em homens e mulheres: um estudo de gênero. Cad Saude Publica. 1998; 14 (1): 51-60.

Oliveira MLW, Motta CP. A Hanseníase como Problema de Saúde Pública. In: Lombardi C, Ferreira J, Motta CP, Oliveira MLW, editores. Hanseníase. São Paulo: Imprensa Oficial do Estado, Arquivo do Estado; 1990. p. 21-32.

Oliveira MLW, Mendes CM, Tardin RT, Cunha MD, Arruda A. Social representation of Hansen's disease thirty years after the term 'leprosy' was replaced in Brazil. Hist Cienc Saude Manguinhos. 2003; 10 (suppl. 1): 41-8. 
Omran AR. The epidemiologic transition: a theory of the epidemiology of population change. Milbank Mem Fund. 1971; 49 (4): 509-38.

Opromolla DVA, Arruda OS, Fleury RN. Manutenção de tatus em cativeiro e resultados de inoculação do Mycobacterium leprae. Hans Int. 1980; 5 (1): 2836.

Opromolla DVA. Terapêutica da hanseníase. Medicina, Ribeirão Preto. 1997; 30 (3): $345-50$.

Opromolla DVA. Manifestações Clínicas e Reações. In: Opromolla DVA, editor. Noções de Hansenologia. Bauru: Centro de Estudos Dr. Reynaldo Quagliato, 2000. p. 51-8.

Opromolla DVA, Tonello CJS, Fleury RN. Hanseníase dimorfa e infecção pelo HIV (Aids). 2000; Hans Int. 2000; 25 (1): 54-9.

Opromolla PA, Dalben I, Cardim M. Análise geoestatística de casos de hanseníase no Estado de São Paulo, 1991-2002. Rev Saude Publica. 2006; 40 (5): 907-13.

Opromolla PA, Laurenti R. Controle da hanseníase no Estado de São Paulo: análise histórica. Rev Saude Publica. 2011; 45 (1): 195-203. 
Organização das Nações Unidas (ONU). Emprego, Desenvolvimento Humano e Trabalho Decente: A Experiência Brasileira Recente. [citado 11 nov 2010] Brasília: PNUD, 2008. Disponível em: http://www.pnud.org.br.

Organização Mundial da Saúde (OMS). Manual de Controle da Lepra. $2^{\mathrm{a}}$ ed. Washington: OMS; 1989. p. 18-30: Diagnóstico e classificação.

Organização Mundial da Saúde (OMS). Relatório da Comissão sobre Meio Ambiente e Saúde. Genebra: OMS; 1992.

Organização Mundial da Saúde (OMS). Classificação internacional de doenças e problemas relacionados à saúde. 10ª revisão. São Paulo: Centro Colaborador da OMS para a Classificação de Doenças em Português, Edusp; 1994.

Organização Mundial da Saúde (OMS). Programa de Ação para a Eliminação da Hanseníase. Um guia para eliminar a hanseníase como problema de saúde pública. Genebra, 1995.

Organização Mundial da Saúde (OMS). A estratégia do esforço final para a eliminação da hanseníase: plano estratégico, 2000 - 2005. Genebra: OMS; 2000. 
Organização Mundial da Saúde (OMS). Estratégia Global para maior redução da carga da Hanseníase e sustentação das atividades de controle da Hanseníase, 2006 - 2010. Genebra: OMS; 2005.

Organização Mundial da Saúde (OMS). Doenças Negligenciadas: Hanseníase. OPAS Brasil [citado 11 nov 2010]. Disponível em: http://www.new.paho.org/bra.

Pacheco-Ferreira H, Castro E, Câmara VM. Redemoinhos teóricos: Ambiente e Desenvolvimento Sustentável. Cad Saude Col, 2005; 13 (1): 926.

Paige CF, Scholl DT, Truman RW. Prevalence and incidence density of Mycobacterium leprae and Trypanosoma cruzi infections a population of wild nine-banded armadillos. Am J Trop Med Hyg. 2002; 67 (5): 528-32.

Pallen MJ, Mcdermott, RD. How might Mycobacterium leprae enter the body? Lepr Rev. 1986; 57: 289-98.

Paneth N, Susser E, Susser M. Origins and early development of the casecontrol study. In: Morabia A (editor). A history of epidemiologic methods and concepts. Basel: Birkhauser Verlag; 2004. 
Parra MC. Caracterización socio-económica de los leprosos atendidos en la unidad de dermatologia sanitaria de Maracaibo, Venezuela: un estúdio de casos. Cad Saude Publica. 1996; 12 (2): 225-31.

Penna G, Pinto LF, Soranz D, Glatt R. High Incidence of Diseases Endemic to the Amazon Region of Brazil, 2001 - 2006. Emerg Infect Dis. 2009; 15 (4): 626-32.

Penna MLF. Uma abordagem ecológica da tuberculose. Cad Saude Publica. 1988; 4 (4): 356-62.

Penna MLF, Penna GO. Trend of case detection and leprosy elimination in Brazil. Trop Med Int Health. 2007; 12 (5): 647-50.

Penna MLF, Oliveira ML, Penna GO. The epidemiological behaviour of leprosy in Brazil. Lepr Rev. 2009; 80 (3): 332-44.

Penna MLF, Oliveira MLW, Carmo EH, Penna GO, Temporão JG. The influence of increased access to basic healthcare on trends in Hansen's disease detection rate in Brazil from 1980 to 2006. Rev Soc Bras Med Trop. 2008; 41(Supl 2): 6-10. 
Peiter PC. A Geografia da Saúde na Faixa de Fronteira Continental do Brasil na Passagem do Milênio [tese]. Rio de Janeiro: Universidade Federal do Rio de Janeiro; 2005.

Pessoa SB. Ensaios Médico-Sociais. São Paulo: CEBES / Hucitec; 1978.

Petri V, Oyafuso LK, Trindade MAB. Hanseníase. In: Cimerman S, Cimerman B, editores. Medicina Tropical. São Paulo: Atheneu; 2003. p. 2739.

Pfaltzgraff RE, Bryceson A. Clinical Leprosy. In: Hastings RC, editor. Leprosy. London: Churchill Livingstone; 1985. p. 134-76.

Pillai SC, Kandamuthan M, Joseph A. Observations on the intra familial clustering of leprosy cases in Trivandrum City. Indian J Lepr. 1984; 56 (4): 868-76.

Pimentel MIF, Andrade M, Valle CLP, Xavier AGM, Bittencourt ALP, Macedo LFS. Descentralização do diagnóstico e tratamento da hanseníase no Estado do Rio de Janeiro: Avanços e Problemas. Hans Int. 2004; 29 (2): $94-$ 100. 
Prata PB, Bohland AK, Vinhas SA. Aspectos epidemiológicos da hanseníase em localidades do Estado de Sergipe, Brasil, período de 1994-1998. Hans Int. 2000; 25 (1): 49-53.

Quagliato R. Algumas considerações epidemiológicas em relação ao Censo de 1940 e os casos registrados no D.P.L. do estado de São Paulo. Revista Brasileira de Leprologia. 1951; 19 (3): 139-60.

Queiroz ML, Scatena JHG. Distribuição espacial e temporal da hanseníase em Mato Grosso, no período de 1996 a 2007. Cad Saude Col. 2009; 17 (1): $145-61$.

Rabello Junior. Algumas obsevações relativas ao prognóstico da lepra com utilidade para a conducta do tratamento. Rev Bras Leprol. 1936; 44 (1): 2738.

Ramaprasad P, Fernando A, Madhale S, Rao JR, Edward VK, Samson PD, Klatser PR, De Wit MYL, Smith WCS, Cree IA. Transmission and protection in leprosy: indications of the role of mucosal immunity. Lepr Rev. 1997; 68: $301-15$.

Rao PSS, Karat ABA, Kaliaperumal VG, Karat, S. Prevalence of leprosy in Gudiyatham Taluk, South India. Int J Lepr Other Mycobact Dis. 1972; 40 (2): 157-70. 
Rao S, Garole V, Walawalkar S, Khot S, Karandikar N. Gender differentials in the social impact of leprosy. Lepr Rev. 1996; 67: 190-9.

Raposo MT. Avaliação da implantação do programa do controle da hanseníase na rede básica de Aracajú, Sergipe. [tese]. São Paulo: Faculdade de Medicina da Universidade de São Paulo; 2011.

Rede Interagencial de Informação para a Saúde (RIPSA). Indicadores básicos para a saúde no Brasil: conceitos e aplicações. $2^{\underline{a}}$ ed. Brasília: Organização Pan-Americana da Saúde; 2008.

Rees RFW. The microbiology of Leprosy. In: Hastings RC, editor. Leprosy. London: Churchill Livingstone; 1985. p. 31-52.

Reichenheim ME, Moraes CL. Alguns pilares para a apreciação da validade de estudos epidemiológicos. Rev bras epidemiol. 1998; 1 (2): 13248.

Richardus JH, Habbema JD. The impact of leprosy control on the transmission of M. leprae: is elimination being attained? Lepr Rev. 2007; 78 (4): 330-7. 
Rodrigues-Júnior AL, Tragante do Ó V, Motti VG. Estudo espacial e temporal da hanseníase no estado de São Paulo, 2004-2006. Rev Saude Publica. 2008; 42 (6): 1012-20.

Rojas LI. La Diferenciacion Territorial de la Salud en la Recuperacion de los Contextos. In: Barcellos C, organizador. A Geografia e o Contexto dos problemas de Saúde. Rio de Janeiro: Abrasco; 2008. p. 87-106.

Rotberg A. "N-factor/Anergic Margin" or resistance/susceptibility to hanseniasis. I. The foundations of the theory. Hans Int. 1977; 2 (2): 115-24.

Rotberg A, Bechelli LM. Etiologia e Patologia. In: Tratado de Leprologia. $2^{\mathrm{a}}$ edição. Rio de Janeiro: Serviço Nacional de Lepra; 1950.

Sabroza PC, Santos EM, Andrade V, Hartz Z. Linhas de pesquisas operacionais na área de hanseníase no âmbito da vigilância em saúde - uma proposta. Hans Int. 2000; 25 (2): 143-6.

Sabroza PC, Toledo LM, Osanai $\mathrm{CH}$. A organização do espaço e os processos endêmico-epidêmicos. In: Leal MC, Sabroza PC, Rodrigues RH, Buss PM, organizadores. Saúde, Ambiente e Desenvolvimento: Processos e Consequências sobre as Condições de Vida. São Paulo: Hucitec; 1992. p. 57-77. 
Samaja J. Desafíos a la epidemiología. Rev bras Epidemiol. 2003; 6 (2): 10520.

Sampaio SAP, Rivitti EA. Dermatologia. $2^{\underline{a}}$ ed. São Paulo: Artes Médicas; 2000.

Santos LAC, Faria L, Menezes RF. Contrapontos da história da hanseníase no Brasil: cenários de estigma e confinamento. Revista brasileira de Estudos populacionais. 2008; 25 (1): 167-90.

Santos LP, Rabay FO. Perfil epidemiológico da hanseníase no município de Taubaté - SP no ano de 1999. Hans Int. 2001; 26 (2):112-6.

Santos M. Meio Técnico-científico e Urbanização: Tendências e Perspectivas. Da Totalidade ao Lugar. São Paulo: Edusp; 2002. p. 119-36.

Santos M. Por uma Geografia Nova. 6ª ed. São Paulo: Edusp; 2002.

Santos M. Economia Espacial. 2ª ed. São Paulo: Edusp; 2003.

Santos M. O Espaço dividido. 2ª ed. São Paulo: Edusp; 2004.

Santos M. A Urbanização Brasileira. 5ª ed. São Paulo: Edusp; 2005. 
Santos M. A Natureza do Espaço. 4ª ed. São Paulo: Edusp; 2006.

Santos M. Espaço e Método. 5aㅡ ed. São Paulo: Edusp; 2008.

Santos M. Pobreza Urbana. 3ª ed. São Paulo: Edusp; 2009.

Santos M, Silveira ML. O Brasil: território e sociedade no início do século XXI. $7^{\text {a }}$ ed. Rio de Janeiro: Record; 2005.

Sauvy A. Elementos de Demografia. Rio de Janeiro: Zahar; 1979.

Savassi LCM. Hanseníase: políticas públicas e qualidade de vida de pacientes e seus cuidadores [dissertação]. Belo Horizonte: Fundação Oswaldo Cruz, Centro de Pesquisas René Rachou; 2010.

Schnitzler R. Hanseníase. In: Amato Neto V, Baldy JLS, editores. Doenças Transmissíveis. São Paulo: Sarvier; 1989. p. 451-65.

Schwartz S. The Fallacy of the Ecological Fallacy: The Potential Misuse of a Concept and the Consequences. Am J Public Health. 1994; 84 (5): 819-23.

Scollard DM, Adams LB, Gillis TP, Kraenbuhl JL, Truman RW, Willians DL. The continuing challenges of leprosy. Clin Microbiol Rev. 2006; 19 (2): 33881. 
Sen P, Ranjan R, Middleton JR. Hansen's disease in a native-born, United States resident, after a brief stay in an endemic area abroad. Int $J$ Infect Dis. $2001 ; 5(1): 49-52$.

Shepard GG. Leprosy today. N Engl J Med. 1982; 307: 1640-1.

Silva CAF. Fronteira agrícola capitalista e o ordenamento territorial. In: Santos M, Becker BK, organizadores. Território, Territórios: Ensaios sobre o ordenamento territorial. $2^{\mathrm{a}}$ ed. Rio de Janeiro: DP\&A Editora; 2006. p. 283312.

Silva DRX, Ignotti E, Souza-Santos R, Hacon SS. Hanseníase, condições sociais e desmatamento na Amazônia brasileira. Rev Panam Salud Publica. 2010; 27 (4): 268-75.

Silva LJ. Crescimento Urbano e Doença. A Esquistossomose no Município de São Paulo (Brasil). Rev Saude Publica. 1985a; 19: 1-7.

Silva LJ Considerações acerca dos fundamentos teóricos da explicação em Epidemiologia. Rev Saude Publica. 1985b; 19: 377-83.

Silva LJ. Desbravamento, agricultura e doença: a doença de Chagas no Estado de São Paulo. Cad Saude Publica. 1986; 2 (2): 124-140. 
Silva LJ. O conceito de espaço na epidemiologia das doenças infecciosas. Cad Saude Publica. 1997; 13 (4): 585-93.

Silva Sobrinho RA, Mathias TAF. Perspectivas de eliminação da hanseníase como problema de saúde pública no Estado do Paraná, Brasil. Cad Saude Publica. 2008; 24 (2): 303-14.

Silveira RP, Damasceno D, Muniz V, Lagoas VL, Raele S, Oliveira PP. Tendência da endemia de hanseníase no estado do Acre: evolução das formas clínicas de 1996 a 2006. Cad Saude Col. 2009; 17 (1): 163-74.

Smith WCS, Smith CM, Cree IA, Jadhav RS, Macdonald M, Edward VK, Oskam L, Beers S, Klatser, P. An approach to understanding the transmission of Mycobacterium leprae using molecular and immunological methods: results from the MILEP2 Study. Int $J$ Lepr Other Mycobact Dis. 2004; 72 (3): 269-77.

Soares dos Santos E, Magalhães MCC, Queiroz ML, Borges RCM, Lima ML, Souza MS, Ramos Junior AN. Distribuição espaço-temporal da hanseníase em Mato Grosso. Hygeia. 2010; 6 (10): 53-62.

Sodré NW. Introdução à geografia; geografia e ideologia. Petrópolis: Vozes; 1986. 
Sommerfelt H, Irgens LM, Christian M. Geographical variations in the occurrence of leprosy: possible roles played by nutrition and some other environmental factors. Int J Lepr Other Mycobact Dis. 1985; 53 (4): 524-32.

Souza Araújo H. Poderá o carrapato transmitir a lepra? Mem Inst Oswaldo Cruz. 1941; 36 (4): 577-84.

Souza CS. Hanseníase: formas clínicas e diagnóstico diferencial. Medicina, Ribeirão Preto. 1997; 30: 325-34.

Souza WV, Barcellos CC, Brito AM, Carvalho MS, Cruz OG, Albuquerque MFM, Alves KR, Lapa TM. Aplicação de modelo bayesiano empírico na análise espacial da ocorrência de hanseníase. Rev Saude Publica. 2001; 35 (5): $474-80$.

Starfield B. Atenção primária: equilíbrio entre necessidades de saúde, serviços e tecnologia. Brasília: UNESCO, Ministério da Saúde; 2002.

Stata 10 [computer program]. College Station (Texas): Statcorp, Data Analysis and Statistical Software; 2007.

Storrs EE. The nine-banded armadillo: a model for leprosy and other biomedical research. Int J Lepr Other Mycobact Dis. 1971; 39: 703-14. 
Susser M. The Logic in Ecological: I. The Logic of Analysis. Am J Public Health. 1994; 84 (5): 825-29.

Tello EE. Condiciones socio-economicas y hanseniasis. Comparación durante 30 anos entre la consulta privada y un dispensario especializado. Hans. Int. 1978; 3 (2): 160-4.

Trindade MAB, Teixeira PR, Paula SR. Incapacidades físicas em hanseníase no momento do diagnóstico, II - Indicador para avaliação do Programa de Controle da Hanseníase. Hans Int. 1987; 12 (2): 29-37.

Trindade MAB, Wen CL, Festa Neto C, Escuder MM, Andrade VLG, Yamashitafuji TMT, Manso VLS. Accuracy of store-and-forward diagnosis in leprosy. J Telemed Telecare. 2008; 14: 208-10.

Truman R. Leprosy in wild armadillos. Lepr Rev. 2005; 76: 198-208.

Truman R, Singh P, Sharma R, Busso P, Rougemont J, Paniz-Mondolfi A, Kapopoulou A, Brisse S, Scollard DM, Gillis TP, Cole ST. Probable Zoonotic Leprosy in the Southern United States. N Engl J Med. 2011; 364: 1626-33.

Ura S, Opromolla DVA. Epidemiologia. Controle. In: Opromolla DVA, editor. Noções de Hansenologia. Bauru: Centro de Estudos Dr. Reynaldo Quagliato, 2000. p. 101-12. 
Van Brakel WH. Peripheral neurophaty in leprosy and its consequences. Lepr Rev. 2000; 71: 146-53.

Waksal S. Imunomodulação: Imunopotencialização, Tolerância e Imunossupressão. In: Bellanti JA. Imunologia. $2^{\mathrm{a}}$ edição. Rio de Janeiro: Interamericana; 1980.

Walker SL, Lockwood DNJ. The clinical and immunological features of leprosy. British Med Bull. 2006; 77/78:103-21.

Walsh GP, Meyers WM, Bindford CH, Gerome PJ, Wolf RH, Leininger JR. Leprosy - a zoonosis. Lepr Rev. 1981; 52 (1): 77-83.

World Health Organization. Progress towards the elimination of leprosy as a public health problem. Wkly Epidemiol Rec. 1995; 70 (25): 177-82.

World Health Organization. Leprosy Global situation. Wkly Epidemiol Rec. 2002; 1 (77): 1-8.

World Health Organization. Global leprosy situation, beginning of 2008. Wkly Epidemiol Rec. 2008; 83 (33): 293-300.

World Health Organization. Leprosy. Geneva, 2009 [cited 2010 dec 13]. Available from: http://www.who.int/lep/situation. 
World Health Organization. Global leprosy situation, 2009. Wkly Epidemiol Rec. 2009; 84 (33): 333-40.

World Health Organization. Global leprosy situation, 2010. Wkly Epidemiol Rec. 2010; 85 (35): 337-48.

Worth RM. Leprosy in Hawaii, the end of an epidemic [editorial]. Int $J$ Lepr Other Mycobact Dis. 1996; 64 (4): 441-7.

Worth RM, Bomgaars MR. Immigration and leprosy in Hawaii, 1960-1981. Int J Lepr Other Mycobact Dis. 1982; 50 (3): 335-41.

Young SK, Taylor GM, Jain S, Suneetha LM, Suneetha S, Lockwood DNJ, Young DB. Microsatellite Mapping of Mycobacterium leprae Populations in Infected Humans. J Clin Microbiol. 2004; 42 (11): 4931-6.

Zanetta DMT. Análise Exploratória: procedimentos básicos para análise de conjunto de dados. In: Massad E, Menezes RX, Silveira PSP, Ortega NRS. Métodos Quantitativos em Medicina. Barueri: Manole, 2004. p. 127-49. 